\title{
ADVANCED COAL-FUELED INDUSTRIAL COGENERATION GAS TURBINE
} SYSTEM

Annual Report for the Period June 1990-June 1991

By

R. T. LeCren

L. H. Cowell

M. A. Gallca

M. D. Stephenson

C. S. Wen

July 1991

Work Performed Under Contract No. AC22-86MC23166

For

U.S. Department of Energy

Morgantown Energy Technology Center

Morgantown, West Virginia

By

Solar Turbines, Inc.

San Diego, California 


\section{DISCLAIMER}

This report was prepand as an account of work sponsored by an agency of the United States Government. Neither the United States Government nor any agency thereof, nor any of their employees, makes any warranty, express or implied, or assumes any legal liability or responsibility for the accuracy, completeness, or usefulness of any information, apparatus, product, or process disclosed, or represents that its lise would not infringe privately owned rights, Reference herein to any specific commercial product, process, or service by trade name, tradernark, manufacturer, or otherwise daes not nectssarily constitute or imply its endorsement, recommendation, or favoring by the United States Government or any agency thereof. The views and opinions of authors $c x$ pressed herein do not necessarily state or reflect those of the United States Government or any agency thereof.

This report has been reproduced directly from the best available copy.

Available to DOE and DOE contractors from the Office of Scientific and Technical Information, P.O. Box 62, Oak Ridge, TN 37831; prices available from (615)576-8401, FTS 626-8401.

Available to the public from the National Technical Information Service, U.S. Department of Commerce, 5285 Port Royal Rd., Springfield, VA 22161. 


\title{
Advanced Coal-Fueled Industrial Cogeneration Gas Turbine System
}

\author{
Annual Report \\ June 1990 - June 1991 \\ R.T. LeCren \\ L.H. Cowell \\ M.A. Galica \\ M.D. Stephenson \\ C.S. Wen
}

Work Performed Under Contract No.: DE-AC21-86MC23166

\author{
For \\ U.S. Department of Energy \\ Office of Fossil Energy \\ Morgantown Energy Technology Center \\ P.O. Box 880 \\ Morgantown, West Virginia 26507-0880 \\ By \\ Solar Turbines, Inc. \\ Product Development Center \\ P.O. Box 85376 \\ San Diego, California 92186-5376
}

July 1991 


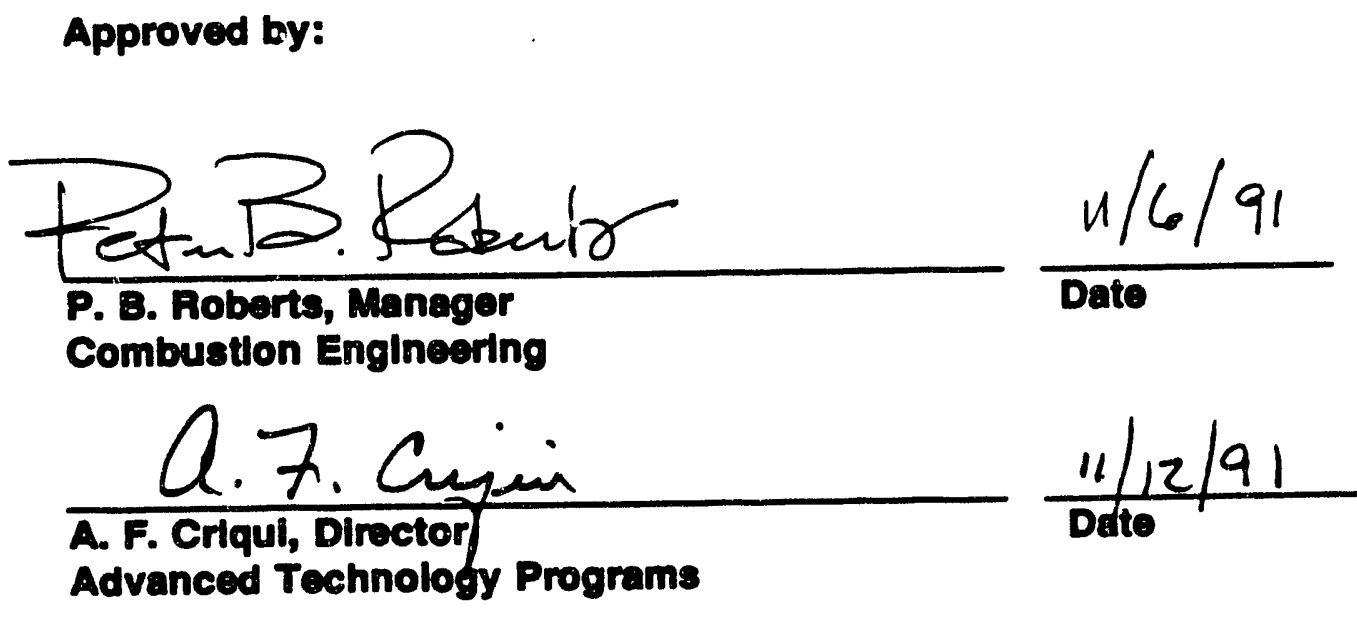




\section{CONTENTS}

Section

Page

1

INTRODUCTION

1

2

SUMMARY

3

PHASE II - TASK 1 - COMBUSTOR DEVELOPMENT

$\begin{array}{lll}3.1 & \text { Specific ltems of Progress } & 7\end{array}$

3.1.1 Subscale Combustor Testing 7

3.1.2 Full-Scale Combustor Development $\quad 7$

$\begin{array}{lll}3.2 & \text { Discussion } & 7\end{array}$

3.2.1 Subscale Combustor Testing 8

4 PHASE II - TASK 2 - PARTICULATE REMOVAL SYSTEM DEVELOPMENT 41

4.1 Specific Items of Progress 41

4.1.1 Post-Primany System $\quad 41$

4.1.2 Post-Secondary System 41

4.2 Discussion 42

4.2.1 Primary Cleanup Device $\quad 42$

4.2.2 Post-Secondary Systems 48

5 PHASE II - TASK 4 - COAL FUEL SPECIFICATION DEVELOPMENT 69

5.1 Specific liems of Progress $\quad 69$

$\begin{array}{ll}5.2 \text { Discussion } & 70\end{array}$

5.2.1 Coal Fuel Specification $\quad 70$

5.2.2 Fuel Preparation Tests 81

$6 \quad$ PHASE II - TASK 6 - HOT END SIMULATION 93

6.1 Specific Items of Progress 93

6.2 Discussion 93 
CONTENTS (Continued)

Section

7
PHASE III - TASK 1 - DESIGN

7.1 Specific Items of Progress

7.2 Discussion

APPENDIX A
Page

103

103

103

105

IV 


\section{FGURES}

\section{Flgure}

TSSC Test Configuration for Evaluation of Fuels of Varying Properties

Outlet Temperature Profile of TSSC Buming CWMs of Varying

Coal Loadings

NO $\mathrm{x}$ Emissions of TSSC Buming CWMs of Varying Coal Loadings

Variation of Outlet Temperature With fuels of Varying Coal Ash

Variation of $\mathrm{NO}_{x}$ Emissions With Fuels at Varying Coal Ash

Outlet Temperature and Emission Characteristics of TSSC Buming

Outlet Temperature and Emission Characteristics of TSSC Buming CWMs Made From Coals From Different Seams

Combustor Island

Test Set-Up at Caterpillar Tech Center

Full-Scale Combustor Without PRIS

The Temperature History of the Full-Scale Combustor During the First

Temperature-Time History of F/S Combustor During Test No. 2

The Temperature-Time History of the Full-Size Combustor at Several Locations for Test No. 4

The Variation of Emissions and Outlet Temperature Versus Equivalence Ratio for Test No. 4 
FIGURES (Continued)

Fqure

Page

A Downstream View of the Secondary Combustor With Slag

Accumulations at the Secondary Air Inlet Ports

40

20

SEM Analysis of PAIS Rods After IBSTF Test No. 9

43

21

Alumina Rod PRIS Inlet

44

22

Alumina Rod PRIS Outlet

45

PRIS Subscale Rod Material Cast in Support for Mounting in the IBSTF

Sample PRIS Rods Mounted in IBSTF Upstream of Alumina Rod Insert

Full-Scale PRIS Model

The Full-Scale PRIS Design

Full-Size PRIS Components Unassembled

Full-Size PRIS Slag Removal Section

Location of Candle Fallures During Extended Tests

Candle Failure Ànalysis Tree

Imperfections in Candle Wall 
FGURES (Continued)

Flgure

Page

$39 \quad X$-Ray Diffraction Pattern for Used Schumacher Candle 58

40 Frequency Response Curves for Virgin Candle

$41 \quad$ Frequency Response Curves for Exposed Candle 59

42 Typical Trace 62

43 Outine of Drais Perl Mill and Slumy Preparation System 82

44 Relattve Capacity of Stirred Ball Mill Versus Nominal Top Size of Product Slumy

88

45 Relative Capacity of Stirred Ball Mill Versus Hardgrove Grindability Index of Feed Coal

88

46

Full-Size Combustor Tests: Fuel System

89

47

Heater Coil Prior to Material Samples

96

48

Heat Coll With Dusting of Particulate

96

49

Candle Filter Mount

98

50

Conical Primary Zone and Impactor Section 
3 Particulate Sample Analyses From Test Completed in TSSC With CWMs of Varying Fuel Properties

5 Simple PRIS Rods to be Evaluated for Hot Corrosion/Erosion in IBSTF Test No. 10

Summary of Location of Candle Breakages

Four-Point Bend Test Data for Candle Specimens

8 EDX Test Data for Candle Specimens

9 Resonant Frequency Data for Virgin and Exposed Candles

Addition of Sorbents per 100 lbs of Coal to Desulfurize to 75 ppmw $\mathrm{SO}_{2}$

Reactants and Products from Dolomite and Hydrated Lime 


\section{TABLES (Continued)}

\section{Table}

Page

20

Composition Analyses of Candle Dust and Sorbent

21

Leachablilty Measurement of Slag and Candle Dust

80

22

Slag-Quench Water Analysis

81

23

On-Site Grinding and Slurry Preparation

83

24

Variables in Finish Grinding Investigation

87

25

Operating Cost Summary for CWM Fuel Plan at User Site

92

26

Summary of Hot End Simulation Rig Testing

94 


\section{ABBREVIATIONS AND SYMBOLS}

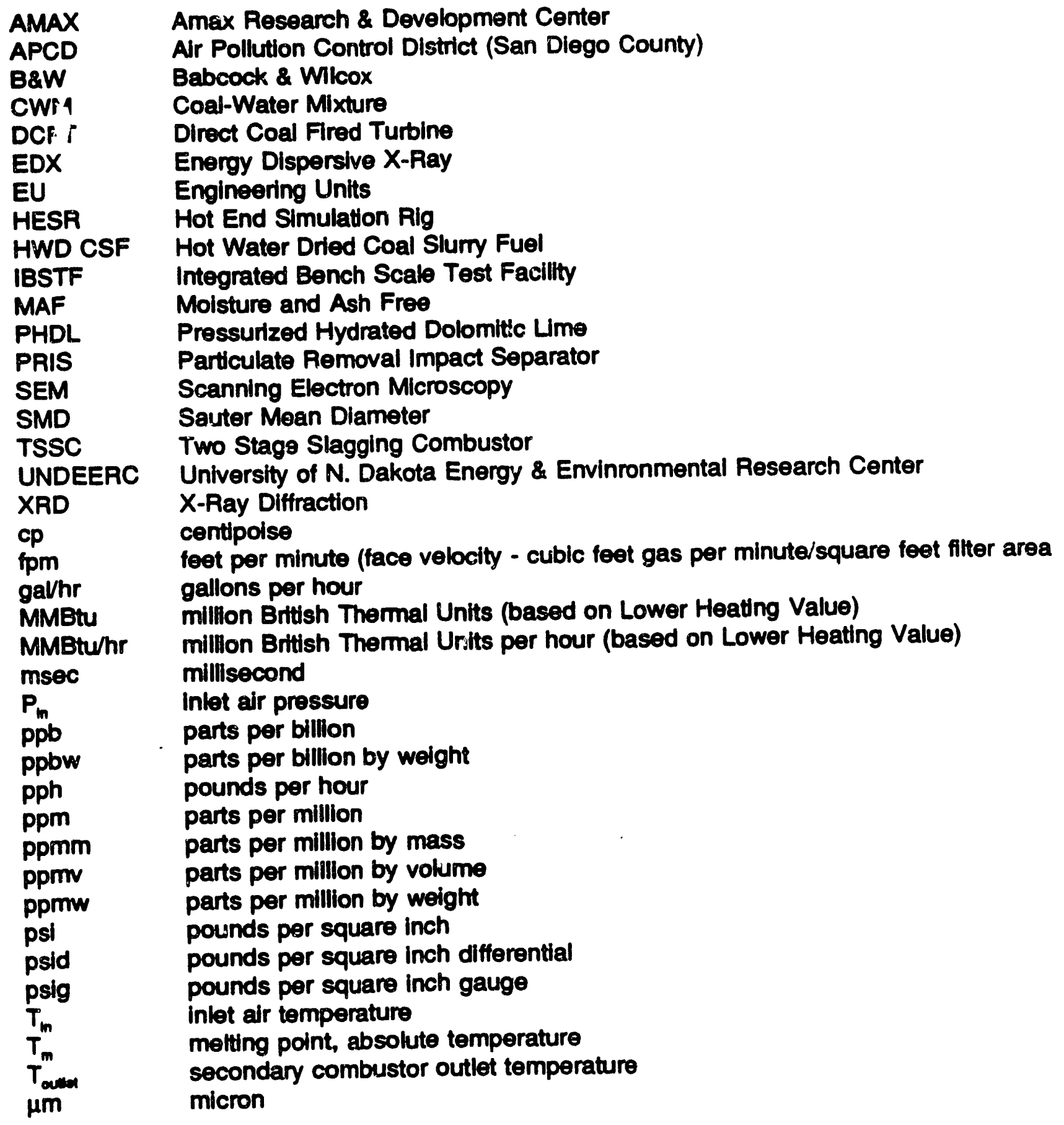

Note: Gaseous emissions $\left(\mathrm{NO}_{\mathrm{x}}, \mathrm{CO}, \mathrm{UHC}, \& \mathrm{SO}_{2}\right.$ ) are quoted in parts per million by volume corrected to $15 \%$ oxygen in the exhaust on a dry basis unless otherwise specified. 


\section{INTRODUCTION}

Advances in coal-fueled gas turbine technology over the past few years, together with recent DOE-METC sponsored studies, have served to provide new optimism that the problems demonstrated in the past can be economically resolved and that the coal-fueled gas turbine can ultimately be the preferred system in appropriate market application sectors.

The objective of the Solar/METC program is to prove the technical, economic, and environmental feasibility of a coal-fired gas turbine for cogeneration applications through tests of a Centaur Type $H$ engine system operated on coal fuel throughout the engine design operating range.

The five-year program consists of three phases, namely:

- Phase I - System Description

- Phase II - Component Development

- Phase III - Prototypo System Verification

A successtul conclusion to the program will initiate a continuation of the commercialization plan through extended field demonstration runs. 


\section{SUMMARY}

This report covers the activity during the period from 2 June 1990 to 1 June 1991. The major areas of work include: the combustor (sub-scale testing and full size design and fabrication), cleanup, coal fuel specification and processing, and the Hot End Simulation rig.

To date Solar has demonstrated:

- Stable and efficient combustion burning coal-water mixtures using the Two Stage Slagging Combustor.

- Molten slag removal of over $\mathbf{9 7 \%}$ using the slagging primary and the particulate removal impact separator

During the past year the following tasks were completed:

- A continous slag removal system was tested on the scalo combustor providing design information for the full size configuration

- Completed an evaluation on coal-water mixture properties on combustor performance

- Procured new stronger candle filters for evaluation in the Integrated Bench Scale Test Facility

During the past year the following tasks were started:

- Testing of the full size combustor at the Caterpillar Tech Center in Peoria, Ilinois

- Development of a Lean Particulate Removal Impact Separator as an altemative to the ceramic barrier secondary filter

- Work at Purdue University on an altemate fuel injector design which will significally reduce the amount of air assist required

- Design of the turbine modifications required to integrate the combustor island with the engine

Combustor testing during the past year has included work on the two subscale combustors (the TSSC and the (BSTF) and the full size combustor. Some of the testing was devoted to developing a continuous slag removal system. A system which featured a water bath into which the molten slag drops was tested on the TSSC rig. The quenched slag is removed through a lock hopper arrangement. Results were promising and provided adequate data and information for the design of the full size system which will be required for the proof-of-concept engine test in Phase III.

A series of tests, 10 in all, were nu on the TSSC rig to evaluate the effects of CWM properties on combustion performance. The CWM properties which were varied included: loading, top size, 
ash concentration, additives and source seams. Loading was varied from $50 \%$ to $58.2 \%$ with little effect on penformance ( $\mathrm{NO}_{x}$, slag capture, carbon conversion and outlet temperature). Increasing the loading results in increased pumping and handling problems. The ash concentration ranged from $3.7 \%$ to $12.8 \%$. Carbon conversion and slag capture appeared to increase with increasing ash content. Other parameters were not effected. Higher coal ash did result in faster refractory degradation. CWM's with particle top sizes of 25,45 and $75 \mu \mathrm{m}$ were tested with little noticeable effect on combustor performance. The slag capture appeared to be the highest with $45 \mu \mathrm{m}$ top size. CWM's from four different coal seams were evaluated. There was no significant difference in combustor performance. The highest carbon conversion was obtained with a coal with the lowest volatlle content and the highest slag capture ccsurred with a coai with high iron content in the ash.

The full size combustor was designed, fabricated and installed at the Caterpillar Tech Center in Peoria, lilinois. Following a series of checkout tests using diesel fuel the first coal burning test occurred on May 23, 1991. Test duration on coal was 2.5 hours, operation was stable and initial performance data were as expected. However the primary to secondary zcne flow split was not optimum and the exhaust system (back pressure valve) is undersized so that desired operating conditions could not be maintained throughout the test. Post test inspection revealed that the impactor had falled possibly due to incomplate curing of the refractory. Corrections to these problems are in process.

The failed silicon carbide rods in the subscale Particulate Removal Impact Separator (PRIS) were analyzed. The failures experienced were due to degradation by reactions of iron from the coal ash with silica from the rods which forms an iron sillicate which is easily eroded. The subscale PRIS has been rebuilt with alumina rods and has accumulated a minimal amount of time on coal, however a $\mathbf{5 0}$ hour test of the $\mathrm{ig}$ is scheduled shortly. The full size PRIS was designed based on experience gained from the subscale unit and on results from a full-size flow model. Fabrication of the full-size PAIS is complete except for the spool section with the rods. Fod material selection is deferred until the end of the $\mathbf{5 0}$ hour test mentioned above. The full-size PAis will be integrated into the rig as soon as it is available.

A second set of ceramic candles was procured. These candles, from a different vendor, are stronger and do not have the transition zone from dense to Altering in the area where failures have occurred. After review of the candle fallures reported in the last annual report a program was established which included testing the second set of candles, conducting flow tests of the vessel, and retaining a consultant. The test program has been hampered by the necessity to Install a venturi scrubber to meet local APCD particulate limits so that a permit to operate can be issued.

As an added task in the revised program work was started on a lean PRIS to replace the ceramic barrier fitter. This device would be based on the rich zone PRIS already tested but would vary in that it operate in a lean zone at temperatures below the slagging temperature of the coal ash. A number of approaches being considered including the addition of materials to make the mineral matter fluid.

In the area of coal fuel specification development a number of significant activities took place. A large lot of CWM ( 4500 gallons) for the full-size testing was prepared by AMAX and delivered to the Caterpillar Tech Center in Peoria. The storage tank and associated pumps, heaters and 
stiming equipment were installed and checked out. So far no major problems have occurred, but It is obvious that the logistics of supplying CWM for the engine test in Phase III indicate that onsite slumy preparation had to be considered. To investigate that scenario a Drais Mill system with capacity to support the subscale rigs was leased. It has been setup and is ready to start preparing slurry on-site to be bumed in the TSSC. The fuel cost spreadsheet has been updated to project Centaur Type $\mathrm{H}$ fuel costs for various scenarios.

A number of test runs and modifications have been made in the Hot End Simulation Rig (HESR) in an effort to be able to run long duration tests. Because of the low fuel firing rate selected to minimize fuel costs heat loss is a serious problem. In order to maintain the gas temperature at the sample section electric heaters were installed immediately upstream of the sample section. Installation problems have occurred and are being addressed along with a review of other heating schemes. Some work was accomplished with the candle installation and mounting. This included evaluation of gasket materials to provide a gas tight seal and the installation of a shroud to prevent direct impingement of the gas on the candle. One of the new stronger candles obtained for the next run in the IBSTF has been tested in the HESR with very encouraging results.

Phase Ili activities were started in March 1991. The initial activity is the design and procurement of the hardware to convert a standard Centaur Type $\mathrm{H}$ so that the coal-fueled combustor island can be integrated. The turbine inlet scroll will be steam cooled in order to accommodate the required turbine inlet temperature of approximately $1920^{\circ} \mathrm{F}$ and to trim the radial inlet temperature profile. Planning and selection of equipment for the engine test site is also in progress. 


\section{PHASE II - TASK 1 - COMBUSTOR DEVELOPMENT}

\subsection{SPECIFC ITEMS OF PROGRESS}

\subsubsection{Subscale Combustor Testing}

- Development of a subscale continuous slag removal device has continued. An increase in distance betweon the slag tap and water bath has proven to be effective in getting all the slag to flow through the impactor. Bridging of slag below the slag tap has been observed.

- A series of CWMs possessing different properties have been formulated and evaluated in ten combustion tests. The properties that have been studied include coal loading, ash concentration, particle size, CWM additives, and several coal seams.

\subsubsection{Full-Scale Combustor Development}

- The full size primary and secondary combustors without the PRIS have been installed for testing at the Caterpillar Technical Center in Peoria, Illinois. A shakedown and calibration procedure has been completed.

-

Two tests have been completed to cure the refractory and demonstrate the combustor operation on DF \#2. Refractory curing was completed by ramping up the alr temperature over an approximate nine hour period and then starting diesel cumbustion. In the first test diesel combustion was maintained for only 10 minutes due to facility problems. The second test was run to complete the refractory curing process by buming diesel fuel for three hours.

-

CWM combustion was completed the first tme in Test No. 4 following a failed attempt in Test No. 3. The combustor operated stably on CWM reaching anticlpated outlet temperatures. The back pressure valve was undersized resulting in a lowering $\triangle P / P$ as the test proceeded. The flow split was below design at 2.3.

\subsection{DISCUSSION}

Combustion testing has been completed on the subscale Two-Staged Slagging Combustor (TSSC) and the Full Size Combustor. In addition, scaled combustion tests to evaluate the cleanup devices have been completed in the Integrated Bench Scale Test Facillty (IBSTF). This facility is detailed in Section 4.0. The TSSC and the Full Size Combustor hardware have been configured for testing described in this report with only primary and secondary combustors. The TSSC has been used to complete development of a continuous slag removal device and to evaluate a series of fuels with different properties. The tests completed in the TSSC in this reporting period are summarized in Table 1. The tests completed in the Full Size Combustor are summarized in Table 4. 


\subsubsection{Subscale Combustor Testing}

\section{Continuous Slaq Removal}

The continuous slag removal device development has continued in this reporting period. Prellminary work has been completed using a batch water bath and a water bath and lock hopper arrangement. The slag pit geometries tes? are included pictorially in Figure 1.

The water flush slag plt has been modified to enhance the heating capacity of the slag tap hole. An Illustration of the slag tap and water bath designated as Design \#4 is shown in Figure 1(D) with other slag tap geometries tested. The design has been modified by increasing the distance from the slag tap to the water line, by inserting radiant heat shields directly below the slag tap, and by modifying the slag tap torches to allow continuous operation. This slag tap configuration has been tested in TSSC No. 47. Operating conditions and test results are summarized in Tables 1 and 2. Table 2 also includes data taken in TSSC Tests Nos. 45 and 46 for comparison.

Testing has been completed in the TSSC configured as illustrated in Figure 2. This configuration has required that the height of the primary zone be decreased from 24 inches to 16 inches. The height has been decreased because of limittations of the test facility. A decrease in primary zone height results in less available combustion residence time. In past tests slag capture has been influenced the greatest by decreased primary zone height.

Test No. 47 lasted for two hours on CWM. The slag tap torches were operated throughout the test while buming DF\#2 and CWM using a natural gas input pressure drop of 57 psid. The torches used primary air at $620^{\circ} \mathrm{F}$ and $4 \%$ pressure drop. A thermocouple measuring slag tap gas temperature reached a maximum of $2600^{\circ} \mathrm{F}$ before switching to CWM. Refractory wall temperatures measured at the impactor and below the slag tap reached maximums of $2483^{\circ} \mathrm{F}$ and $2049^{\circ} \mathrm{F}$, respectively. The water flush system was operated six times yielding 3 to $5 \mathrm{lbs}$ of slag. The slag collected in the lock hopper was largely in the form of pellets.

In post test inspection the primary zone and injectors were in good shape, but the impactor showed some erosion. The area below and around the impactor was coated with slag but was free of any accumulations indicating that adequate temperatures in the region above the slag tap were achieved to insure slag flow. A total of $5.8 \mathrm{lbs}$ of slag was collected in the lock hopper and water bath. A $2.25 \mathrm{lb}$ plece of slag was bidged across the radiant heat shlelds below the slag tap. Apart from this slag bridge the remainder of the insulation comprising the radiant heat shields was free from slag. The slag bridge may be a result of the torch gas flow but this is unknown. This problem can be averted in the full scale design by slightly increasing the insulating inside diameters below the slag tap. The total slag capture has dropped to $45 \%$ with this TSSC configuration. The drop in slag capture is attributed to the decrease in primary zone height as described eartler.

This test concludes the design investigations of the continuous slag removal system. In this test successful slag tap heating was achleved through the use of slag tap torches. Nearly all the slag separated in the primary zone flowed through the slag tap. The slag collected in the water was 

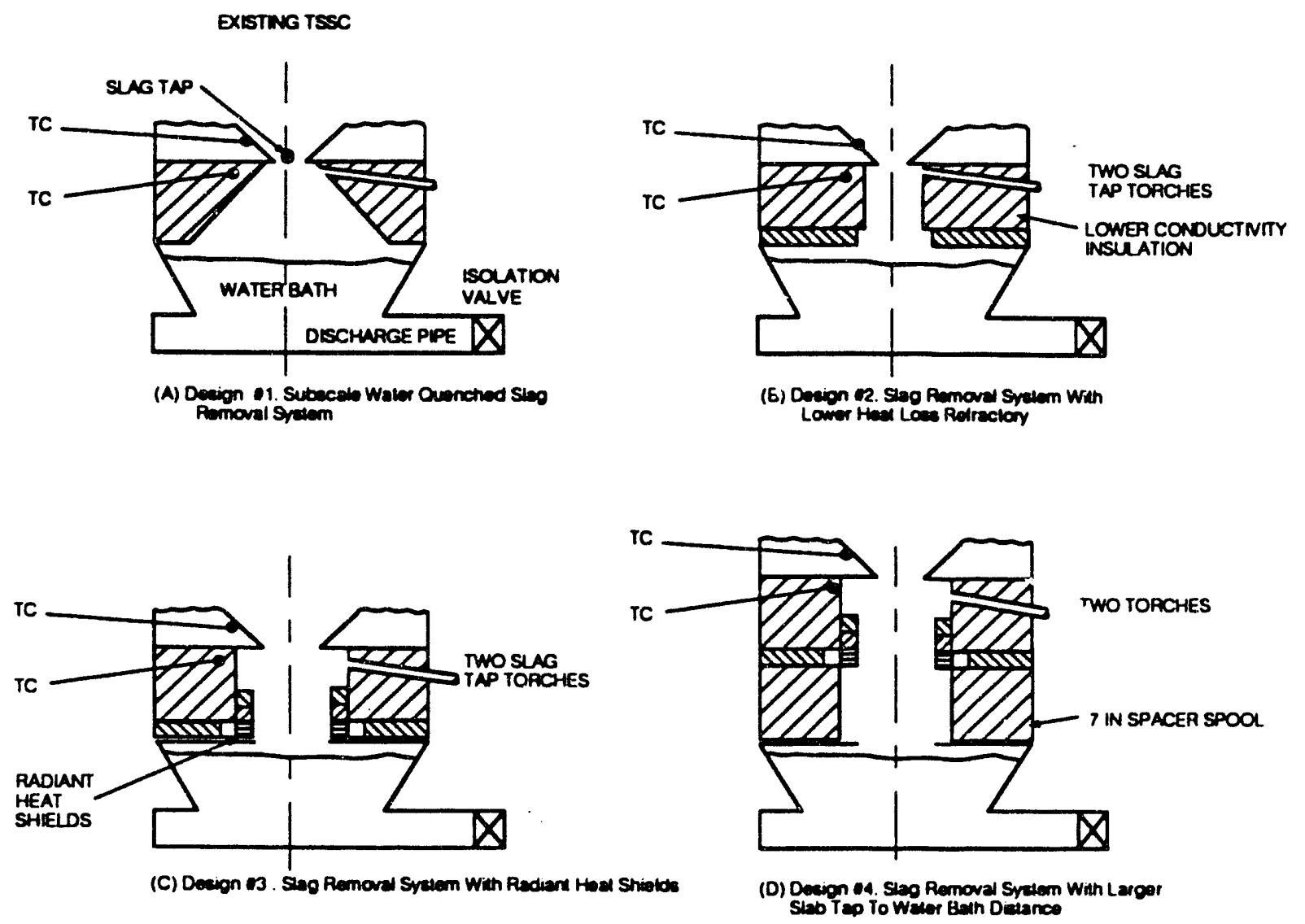

Figure 1. Slag Removal System

small enough to be handled by a moderately sized purge valve and lock hopper. The system used in this test demonstrated removal of 50 to $75 \%$ of the slag collected by the impactor into a lock hopper from the primary zone. This was accomplished desplte the design limitations which had the slag collect in a pipe with a large dead space unaffected by purging.

As a summary the following are important observations and design criteria that will be useful in full scale slag removal system design:

1) The presence of a water bath below the primary zone has no detectable impact on the operation of the combustor.

2) Slag that is quenched in a water bath after dripping through a slag tap is largely in the form of slag pellets of 0.25 to 0.325 inch diameter. The slag is very brittle and easily crushed by hand. This information indicates that an auger/crustier is not necessary. 
Table 1. Summary of CWM Testing of Fuels of Varying Properties

\begin{tabular}{|c|c|c|c|c|c|}
\hline Toet No. & 48 & 49 & 50 & 51 & 52 \\
\hline $\begin{array}{l}\text { CWM } \\
\text { (artical property) }\end{array}$ & $" S 1 "$ & (High Coal Load) & (Low "SA" & $\begin{array}{c}\text { "S6" } \\
\text { (med. ash) }\end{array}$ & $\begin{array}{c}\text { "ST" } \\
\text { (high ash) }\end{array}$ \\
\hline$T_{n}(P F)$ & 653 & 652 & 625 & 626 & 639 \\
\hline$P_{m}$ (paig) & 70.5 & 78.4 & 75.7 & 76.7 & 76.0 \\
\hline$\phi_{\text {maxy }}$ & 1.42 & 1.43 & 1.55 & 1.47 & 1.38 \\
\hline$\Delta P / P\left(\Psi_{0}\right)$ & 3.9 & 3.9 & 4.1 & 4.0 & 4.1 \\
\hline $\begin{array}{l}\text { Hoat Input } \\
\text { (MMBtuhr) }\end{array}$ & 4.68 & 4.71 & 4.67 & 4.36 & 4.20 \\
\hline$T_{\operatorname{man}}\left(P^{\circ} \mathrm{F}\right)$ & 1962 & 2107 & 2107 & 1997 & 1968 \\
\hline \multicolumn{6}{|l|}{ RESULTS } \\
\hline \multicolumn{6}{|l|}{ Emlestons (15\% $\mathrm{O}_{2}$} \\
\hline $\begin{array}{l}\text { NO }_{x} \text { (pprmv) } \\
\text { (1bm/MMBtu) }\end{array}$ & $\begin{array}{c}53.3 \\
(0.2225)\end{array}$ & $\begin{array}{c}68.9 \\
(0.3040)\end{array}$ & $\begin{array}{c}86.3 \\
(0.3885)\end{array}$ & $\begin{array}{c}71.70 \\
(0.3050)\end{array}$ & $\begin{array}{c}67.23 \\
(0.2880)\end{array}$ \\
\hline $\begin{array}{l}\text { CO (ppmv) } \\
\text { (16mMMBw) }\end{array}$ & $\begin{array}{c}6.1 \\
(0.0155)\end{array}$ & $\begin{array}{c}3.2 \\
(0.0083)\end{array}$ & $\begin{array}{c}7.6 \\
(0.0204)\end{array}$ & $\begin{array}{c}12.9 \\
(0.0344)\end{array}$ & $\begin{array}{c}11.8 \\
(0.0304)\end{array}$ \\
\hline $\begin{array}{l}\mathrm{SO}_{2} \text { (ppmv) } \\
\text { (16m/MMBw) }\end{array}$ & NA & $\begin{array}{c}178 \\
(1.064)\end{array}$ & $\begin{array}{c}107 \\
(0.6864)\end{array}$ & NA & $\begin{array}{c}257 \\
(1.5323)\end{array}$ \\
\hline Particulate (ppmm) & 2034.1 & 455.2 & 1584.9 & 1167.2 & 750.2 \\
\hline Carbon Conversion (\%) & 07.2 & $\infty .7$ & 972 & 90.0 & 99.8 \\
\hline \multicolumn{6}{|l|}{ Aah Balance } \\
\hline $\begin{array}{l}\text { Primary Zono Slag } \\
\text { Capture }(\%)\end{array}$ & 372 & 23.9 & 28.9 & 26.0 & 46.0 \\
\hline Ash Emitted (\%) & 22.9 & 26.7 & 53.6 & 24.2 & 14.8 \\
\hline $\begin{array}{r}\text { Imbalanco }(\%) \\
(160)\end{array}$ & $\begin{array}{l}-30.1 \\
-5.8\end{array}$ & $\begin{array}{l}49.3 \\
10.0\end{array}$ & $\begin{array}{l}17.4 \\
4.63\end{array}$ & $\begin{array}{l}49.3 \\
24.2\end{array}$ & $\begin{array}{l}39.1 \\
39.4\end{array}$ \\
\hline
\end{tabular}


Table 1. Summary of CWM Testing of Fuels of Varying Properties (Continued)

\begin{tabular}{|c|c|c|c|c|c|c|}
\hline Test No. & 53 & 54 & 55 & 56 & 57 & 58 \\
\hline $\begin{array}{l}\text { CWM } \\
\text { (ertical property) }\end{array}$ & (no additives) & $\begin{array}{c}\text { "S8" } \\
\text { (fine grind) }\end{array}$ & $\begin{array}{c}\text { "Sg" } \\
\text { (coarso grind) }\end{array}$ & $\begin{array}{l}\text { "S10" } \\
\text { (Upper } \\
\text { Freoport) }\end{array}$ & $\begin{array}{l}\text { "S11" } \\
\text { (Soldior } \\
\text { Creok) }\end{array}$ & $\begin{array}{l}\text { "S12" } \\
\text { (IIIInols } \\
\text { No. 6) }\end{array}$ \\
\hline$T_{n}\left({ }^{\circ} \mathrm{F}\right)$ & 624 & 624 & 628 & 654 & 627 & 618 \\
\hline$P_{m}$ (paig) & 79.9 & 76.1 & 79.7 & 76.0 & 77.0 & 76.0 \\
\hline$\phi_{\text {mangry }}$ & 1.297 & 1.40 & 1.50 & 1.44 & 1.42 & 1.36 \\
\hline$\Delta P / P(\%)$ & 3.00 & 4.0 & 4.0 & 3.9 & 4.0 & 4.10 \\
\hline $\begin{array}{l}\text { Hoat Input } \\
\text { (MMBtu/hr) }\end{array}$ & 4.46 & 5.66 & 4.85 & 4.11 & 4.52 & 4.48 \\
\hline $\mathrm{T}_{\text {and }}\left({ }^{\circ} \mathrm{F}\right)$. & 1794 & 2001 & 2038 & 1971 & 2011 & 1970 \\
\hline \multicolumn{7}{|l|}{ RESULTS } \\
\hline \multicolumn{7}{|l|}{ Emisalons $\odot 15 \% \mathrm{O}_{2}$} \\
\hline $\begin{array}{l}\text { No } \text { (ppmv) } \\
\text { (lbm/MMBtu) }\end{array}$ & $\begin{array}{c}81.90 \\
(0.3833)\end{array}$ & $\begin{array}{c}70.15 \\
(0.3100)\end{array}$ & $\begin{array}{c}65.20 \\
(0.2850)\end{array}$ & $\begin{array}{l}55.40 \\
(0.2783)\end{array}$ & $\begin{array}{c}52.00 \\
(0.2350)\end{array}$ & $\begin{array}{c}43.80 \\
(0.2100)\end{array}$ \\
\hline $\begin{array}{l}\text { CO (ppmv) } \\
\text { (lbm/MMBtu) }\end{array}$ & $\begin{array}{c}109.7 \\
(0.312 \pi)\end{array}$ & $\begin{array}{c}19.8 \\
(0.0540)\end{array}$ & $\begin{array}{c}11.7 \\
(0.0310)\end{array}$ & $\begin{array}{c}20.9 \\
(0.0637)\end{array}$ & $\begin{array}{c}15.9 \\
(0.0450)\end{array}$ & $\begin{array}{c}23.5 \\
(0.2110)\end{array}$ \\
\hline $\begin{array}{l}\mathrm{SO}_{2} \text { (ppmv) } \\
\text { (1bm/MMBtu) }\end{array}$ & $\begin{array}{c}156 \\
(1.0081)\end{array}$ & $\begin{array}{c}156.1 \\
(0.9461)\end{array}$ & $\begin{array}{c}84.7 \\
(0.5250)\end{array}$ & $\begin{array}{c}129.0 \\
(0.9095)\end{array}$ & NA & $\begin{array}{c}40.7 \\
(0.2730)\end{array}$ \\
\hline Particulate (ppmm) & 747.0 & 1038.7 & 872.0 & 169.6 & 235.5 & 1076.1 \\
\hline Carbon Converaion (\%) & 88.4 & 97.0 & 98.5 & 99.8 & 99.6 & 88.1 \\
\hline \multicolumn{7}{|l|}{ Ash Balanco } \\
\hline $\begin{array}{l}\text { Primary Zone Slag } \\
\text { Capture (\%) }\end{array}$ & 22.0 & 21.0 & 18.0 & 31.0 & 23.0 & 54.0 \\
\hline Ash Emitted (\%) & 25.8 & 28.4 & 25.1 & 3.2 & 7.4 & 20.8 \\
\hline $\begin{array}{r}\text { Imbalanco }\left(\%_{0}\right) \\
(\text { (lbe) }\end{array}$ & $\begin{array}{c}9.5 \\
52.2\end{array}$ & $\begin{array}{l}51.0 \\
(15.1)\end{array}$ & $\begin{array}{c}57.4 \\
(16.9)\end{array}$ & $\begin{array}{l}65.9 \\
42.8\end{array}$ & $\begin{array}{l}69.2 \\
24.8\end{array}$ & $\begin{array}{c}19.6 \\
9.4\end{array}$ \\
\hline
\end{tabular}


Table 2. Summary of TSSC Combustor Testing of Slag Removal System

\begin{tabular}{|c|c|c|c|}
\hline Test No. & 45 & 46 & 47 \\
\hline Slag Design & 1 & 2 & 4 \\
\hline CWM & $\top T^{\prime}$ & $\mathbf{T}$ & $\mathbf{T}$ \\
\hline$T_{m}\left({ }^{\circ} F\right)$ & 638 & 636 & 644 \\
\hline$P_{h}$ (psig) & 76 & 75 & 61 \\
\hline$T_{\text {ander }}\left({ }^{\circ} \mathrm{F}\right)$ & 1933 & 1960 & 1798 \\
\hline$\phi_{\text {promery }}$ & 1.39 & 1.37 & 1.38 \\
\hline $\begin{array}{l}\mathrm{No}_{\mathrm{x}} \text { (ppm) } \\
\text { (bmiMBtu) }\end{array}$ & $\begin{array}{c}49.0 \\
(0.1976)\end{array}$ & $\begin{array}{c}48.8 \\
(0.1950)\end{array}$ & $\begin{array}{c}44.3 \\
(0.1781)\end{array}$ \\
\hline $\begin{array}{l}C O \text { (ppm) } \\
\text { (lbmMMBtu) }\end{array}$ & $\begin{array}{c}2.6 \\
(0.0068)\end{array}$ & $\begin{array}{c}2.2 \\
(0.0050)\end{array}$ & $\begin{array}{c}4.3 \\
(0.0103)\end{array}$ \\
\hline $\begin{array}{l}\Delta P / P \text { Pimary } \\
(\%)\end{array}$ & 4.1 & 4.0 & 4.0 \\
\hline $\begin{array}{l}\text { Slag Capture } \\
\text { (wt\%) }\end{array}$ & 70 & -- & 45 \\
\hline $\begin{array}{l}\text { Heat Input } \\
\text { (MMBtu/hr) }\end{array}$ & 4.70 & 5.08 & 4.03 \\
\hline
\end{tabular}

3) In subscale testing slag tap heating is required for the slag to flow through the slag tap. In the full scale this may not be true because of the decreased surface area to volume ratio and the increased slag flow rate. The design of the slag tap heating arrangement is a critical part of the system.

4) An isolation valve can be used to purge most of the slag from the water bath into a lock hopper with no noticeable impact on the system.

5) Design of the passage from the slag tap to the water bath must be sufficlently large to prevent slag bridging while minimizing heat loss.

\section{Fuel Property Specification Testing}

As a means of assessing the flexibility of the TSSC design on using a wide range of CWM fuels a series of tests have been completed with fuels formulated with a range of properties. The testing is to determine if any fuel specifications need to be set for the Coal-Fueled Centaur. The fuel properties that were varied include the coal loading, the ash concentration, the particle size, fuel additives, and bituminous coals from several regional seams. The fuel tests have been completed in the TSSC configuration with the water quench slag removal system as illustrated In Figure 2. As indlcated above this configuration has a decreased primary zone height of 16 inches to accommodate the slag removal design. 


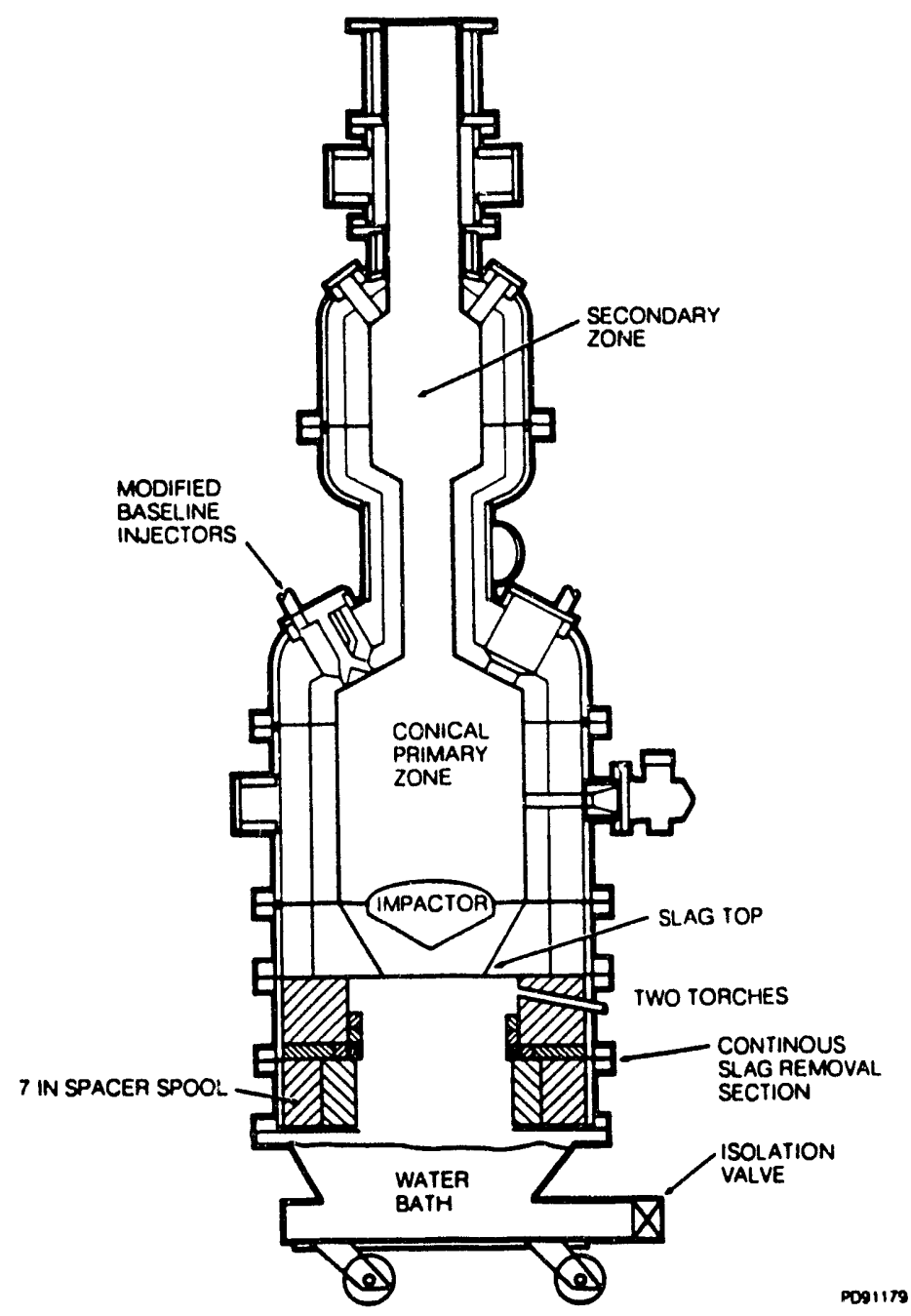

Figure 2. TSSC Test Conflguration for Evaluation of Fuels of Varying Properties

A listing of all the fuels used and their properties are included in Table 16. The tests completed with these fuels and the important results are summarized in Table 1.

Analyses of particulate samples have been completed to provide the carbon conversion and particulate emissions data included in Table 1. This data were taken with the isokinetic sampling probe. The sample is drawn for a four minute periol. The sample is quenched with deionized water and separated from the gas stream in a condensation bath with two gas cyclones and filters. The analyses of the samples for the ten tests are included in Table 3.

\section{Coal Loading}

The influence of CWM coal loading has been investigated burning CWM's of loadings of 54.0, 58.2, and $50.0 \%$ in TSSC Test Nos. 48, 49, and 50, respectively. A summary of the CWM properties of these fuels is included in Table 16. The table illustrates that while slight variations 
Tablo 3. Particulate Sample Analyses From Test Completed in TSSC With CWMs of Varying Fuel Properties

\begin{tabular}{|c|c|c|c|c|c|c|c|}
\hline Teat No. & 48 & 40 & 50 & 51 & 52 & 53 & 54 \\
\hline CWM & "S1" & "S3" & "S4" & $" s 6^{\prime}$ & $" s 7 "$ & $" S 5 "$ & $" S 8 "$ \\
\hline Sollde (g) & 19.28 & 4.82 & 15.87 & 11.35 & 7.38 & 8.51 & 58.6 \\
\hline $\begin{array}{l}\text { Carbon (\%) } \\
\text { Ash (\%) }\end{array}$ & $\begin{array}{l}40.5 \\
59.5\end{array}$ & $\begin{array}{l}16.1 \\
83.0\end{array}$ & $\begin{array}{l}51.4 \\
48.6\end{array}$ & $\begin{array}{l}11.35 \\
25.4\end{array}$ & $\begin{array}{l}7.38 \\
6.8\end{array}$ & $\begin{array}{c}8.51 \\
58.3\end{array}$ & $\begin{array}{l}58.6 \\
41.4\end{array}$ \\
\hline Weter & 11.8 & 16.0 & 11.0 & 10.7 & 13.6 & 13.4 & 8.1 \\
\hline pH & 2.0 & 2.5 & 2.5 & 2.0 & 2.3 & 2.5 & 2.5 \\
\hline \multicolumn{8}{|c|}{ Ach Andyale (\%) } \\
\hline $\begin{array}{l}\mathrm{Al}_{2} \mathrm{O}_{3} \\
\mathrm{Fe}_{2} \mathrm{O}_{2} \\
\mathrm{SlO}_{2}\end{array}$ & $\begin{array}{l}12.63 \\
84.40 \\
15.19\end{array}$ & $\begin{array}{l}11.75 \\
68.31 \\
12.04\end{array}$ & $\begin{array}{l}26.63 \\
24.48 \\
34.43\end{array}$ & $\begin{array}{l}27.86 \\
26.64 \\
35.58\end{array}$ & $\begin{array}{l}24.12 \\
17.23 \\
47.75\end{array}$ & $\begin{array}{l}22.47 \\
32.40 \\
36.11\end{array}$ & $\begin{array}{l}28.08 \\
22.00 \\
38.75\end{array}$ \\
\hline $\mathrm{CaO}^{2}$ & $\begin{array}{r}15.10 \\
0.13\end{array}$ & 2.48 & 5.78 & 0.15 & 3.73 & 3.33 & 0.15 \\
\hline $\mathrm{K}_{2} \mathrm{O}$ & 3.58 & 1.37 & 2.95 & 1.85 & 1.57 & 1.15 & 1.90 \\
\hline $\mathrm{Na}_{2} \mathrm{O}$ & 1.58 & 1.08 & 1.35 & 1.42 & 2.34 & 1.75 & 2.16 \\
\hline $\mathrm{THO}_{2}$ & 0.73 & 0.77 & 1.80 & 1.24 & 0.97 & 0.62 & 2.11 \\
\hline $\mathrm{MnO}_{2}$ & 0.45 & 0.47 & 0.16 & 0.09 & 0.08 & 0.20 & 0.11 \\
\hline $\mathrm{Cr}_{2} \mathrm{O}_{2}^{-}$ & 0.52 & 0.45 & 0.34 & 0.34 & 0.28 & 0.58 & 0.58 \\
\hline NIO & 0.18 & 0.42 & 0.28 & 0.15 & 0.15 & 0.17 & 0.16 \\
\hline CuO & 0.14 & 0.35 & 0.21 & 0.07 & 0.08 & 0.12 & 0.08 \\
\hline MgO & 0.20 & 0.27 & 0.55 & 1.27 & 1.02 & 0.43 & 0.82 \\
\hline $\mathrm{so}_{3}$ & - & 0.25 & 0.04 & 0.28 & 0.04 & 0.17 & 0.41 \\
\hline Pbó & 0.10 & 0.10 & 0.80 & 0.08 & 0.08 & 0.06 & 0.07 \\
\hline $\mathrm{Zno}$ & 0.00 & 0.10 & 0.02 & 2.01 & 0.00 & 0.11 & 0.34 \\
\hline \multicolumn{8}{|c|}{ Woter Anabrele (ppmon) } \\
\hline So, & 437.5 & 228.0 & 620.0 & 350.0 & 320.0 & 240.0 & 304.0 \\
\hline $\mathrm{Cu}$ & 90.43 & 7.37 & 110.5 & 4.84 & 27.30 & $\begin{array}{l}19.90 \\
1770\end{array}$ & $\begin{array}{l}35.3 \\
30.20\end{array}$ \\
\hline$F_{0}$ & $\begin{array}{r}30.80 \\
0.70\end{array}$ & $\begin{array}{r}10.70 \\
2.51\end{array}$ & $\begin{array}{l}36.8 \\
1324\end{array}$ & $\begin{array}{r}40.00 \\
5.40\end{array}$ & $\begin{array}{r}16.00 \\
3.68\end{array}$ & $\begin{array}{r}17.70 \\
7.36\end{array}$ & $\begin{array}{l}30.20 \\
15.80\end{array}$ \\
\hline $\begin{array}{l}A \\
\text { SI }\end{array}$ & $\begin{array}{l}9.79 \\
5.29\end{array}$ & 2.27 & 8.64 & 3.60 & $\begin{array}{l}0.00 \\
1.67\end{array}$ & 3.33 & 7.05 \\
\hline $\mathrm{Na}$ & 18.80 & 1.31 & $3.10^{\circ}$ & 1.75 & 0.81 & 1.82 & 8.70 \\
\hline $\mathrm{Mn}$ & 2.20 & 1.22 & 1.14 & 0.01 & 0.68 & 0.87 & 1.43 \\
\hline $\mathrm{Cr}$ & 1.58 & 0.83 & 2.88 & 7.60 & 0.91 & 1.14 & 1.64 \\
\hline $\mathrm{Ca}$ & 2.98 & 0.68 & 1.56 & 1.07 & 0.64 & 1.14 & 2.01 \\
\hline $\mathbf{M g}_{\mathrm{g}}$ & 3.08 & 0.65 & 1.10 & 0.78 & 0.34 & 0.34 & 3.87 \\
\hline K & 2.81 & 0.57 & 1.85 & 1.45 & 0.62 & 0.60 & 1.45 \\
\hline $\mathbf{N}$ & 1.27 & 0.35 & 1.68 & 5.00 & 0.80 & 1.25 & 1.07 \\
\hline $\mathrm{Zn}$ & 0.47 & 0.37 & 0.30 & 0.27 & 0.11 & 0.11 & 0.19 \\
\hline$\vec{u}$ & 0.02 & 0.01 & 0.03 & 0.10 & 0.10 & 0.01 & 0.01 \\
\hline
\end{tabular}


Tablo 3. Particulate Sample Analyses From Test Completed in TSSC With CWMs of Varying Fuel Propertles (Continued)

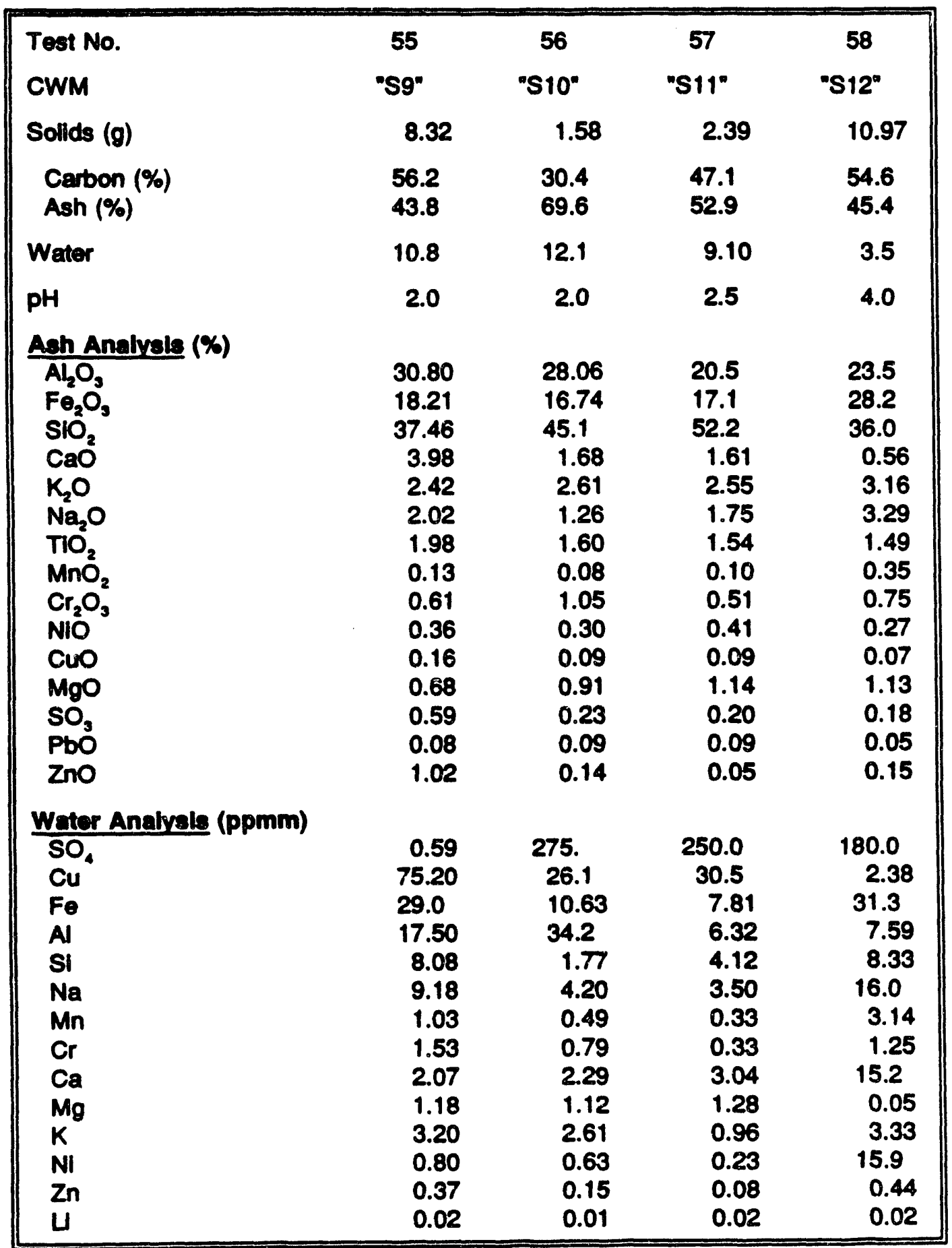


in fuel property exdst the largest variation of the CWM's is in coal loading. Coal loading influences several of the parameters listeci in Table 16 in particular; slumy viscosity, slumy LHV, and to a lesser degree CWM ash content. Efforts were made to control viscosity through the addition of stabllizer and dispersant, but for a non-riewtonian fluid the viscosity will vary independently of shear rate. The CWM's listed in Table 16 have the same viscosity of $300 \mathrm{cp}$ at $100 \mathrm{sec}^{-1}$, but at $1000 \mathrm{sec}^{-1}$ vary from 185 to $500 \mathrm{cp}$.

The fuel handing properties varied substantially between the CWMs of three different loadings. CWMs "S1" and "S4" were readlly pumped through the system and irito the combustor. "S3" of higher loading was more difficult to pump resulting in higher pump pressures and larger variations In fuel flow rate. The difficulty in pumping each fuel appears to be proportional to the viscosity at $1000 \mathrm{sec}^{-1}$. While fuels of loadings in excess of $58 \%$ could be efficiently utilized in the combustor a refinement to the pumping system would be required.

The combustor exhiblted good operation with all three fuels. The combustion tests were operated at nearty identical conditions as listed in Table 1. The largest variation in test conditions was in primary zone equivalence ratio. The tests were to be operated at an equivalence ratio of 1.38. The values listed in Table 1 are all higher, particularty in Test No. 50. The discrepancy stems from the additional fuel input through the slag tap torches and the inerisciency in combustion as reflected in carbon comversion. Typically, the air/tuel ratio is tracked and controlled during testing through the measured air and fuel inputs. The primary equivalence ratio is then calculated based on the measured $\mathrm{O}_{2}$ concentration. Often a considerable discrepancy can exist between these two for the reasons sighted above.

The outlet temperature is dependent on the primary equivalence ratio and the coal loading of the huel. This relation is lliustrated in Figure 3. Graphed is outlet temperature versus equivalence ratio for the fuels with the three loadings. A trend of increasing coal loading producing increasing outlet temperature is shown. It should be noted that the data shown from Test No. 43 was taken while the combustor was operating without the slag tap heating torches. The remaining data was taken at a constant slag tap torch heat input. The influence of coal loading on outlet temperature is not large for the data taken with fuels of 50 and $54 \%$ coal loading.

The emissions are summarized in Table 1 and in Figure 4. The values in Table 1 are averaged over the entre test. Emissions of CO were below $15 \mathrm{ppmv} @ 15 \% \mathrm{O}_{2}$ for all fuels tested. $\mathrm{SC}_{2}$ emissions are a function of the sulfur loading of the fuel as nearly all the sulfur input into the combustor in the fuel is converted to $\mathrm{SO}_{2}$. Therefore, neither $\mathrm{CO}$ or $\mathrm{SO}_{2}$ emissions are influenced by coal loading over this range of test conditions.

The emissions of $\mathrm{NO}_{x}$ are of greater interest. relative to the influence of coal loading on combustor performance. Figure 4 is a graph of $\mathrm{NO}_{x}$ ermissions versus equivalence ratio for the three different coal loadings. Interestingly, the lowest $\mathrm{NO}_{x}$ emissions are achieved with the fuel with the middle coal loading of $54 \%$. Data is presented with this fuel taken in two tests. As mentioned above Test No. 43 was taken without the slag tap torches operating while in Test No. 48 the torches were in operation. The curve through these data suggest that the torches had no infiuence on $\mathrm{NO}_{\mathrm{x}}$ emissions. The documented relation between $\mathrm{NO}_{\mathrm{x}}$ emissions and equivalence ratio for the TSSC is lllustrated by that curve plotted over data taken in Test Nos. 43 and 48 . A typical $\mathrm{NO}_{x}$ emission signature would increase as the primary zone equivalence ratio is increased to a peak at 1.05. As the equivalence ratio is further increased the $\mathrm{NO}_{x}$ emissions fall off rapidly 


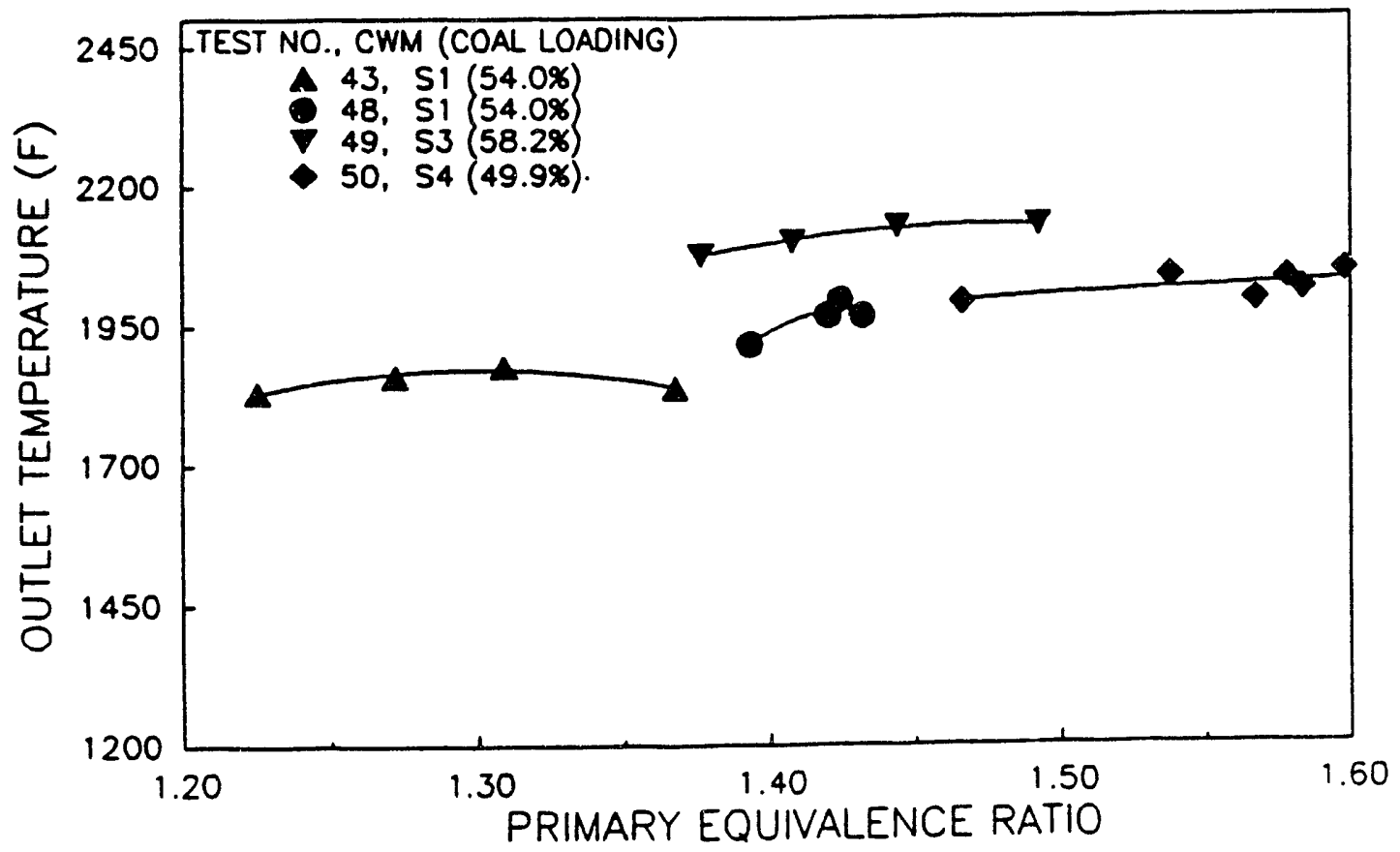

Figure 3. Sutlet Temperature Profile of TSSC Burning CWMs of Varying Coal Loadings

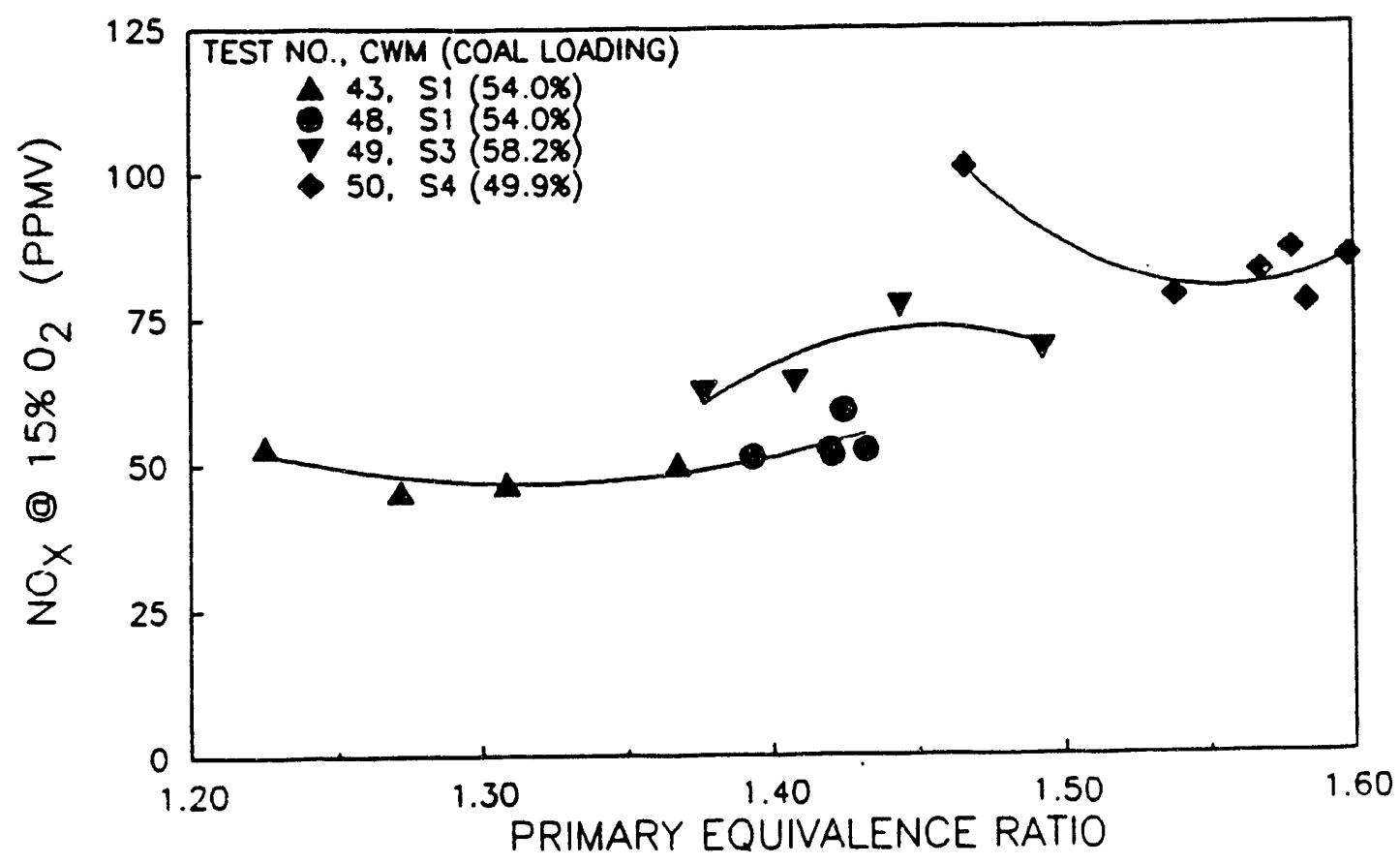

Figure 4. $\mathrm{NO}_{\mathrm{x}}$ Emlssions of TSSC Burning CWMs of Varying Coal Loadings 
to a low at 1.25 to 1.35. The emissions slowly increase with further increases in equivalence ratio. The curve through data from Test Nos. 43 and 48 in Figure 4 lllustrate this trend. The figure suggests that the highest $\mathrm{NO}_{x}$ emissions correspond to the lowest coal loading. This is not an expected result. Typically, as the water loading in the combustor is increased the flame temperature is decreased and correspondingly, so are the $\mathrm{NO}_{x}$ emissions. This trend is exhibited when considering the data presented from Test Nos. 43, 48, and 49. Here the $\mathrm{NO}_{x}$ emissions are increased as the coal loading is increased (and water loading is decreased). In light of the number of data points taken in Test No. 50, the data point taken at the lowest equivalence ratio could be errant and, in fact, if this data is viewed omitting that data point a convincing curve could be drawn corroborating the data from Test Nos. 43, 48, and 50.

The particulate samples indicate that the most efficient combustion was completed with "S3" the $58 \%$ coal fuel. The carbon corversion is the highest with that fuel at $99.7 \%$ and the particulate emissions are the lowest. CWM's "S1" and "S4" with lower coal loadings had worse carbon conversions at $97.2 \%$ for each. This trend can be explained by the higher water vapor concentrations in the primary zone combustor with fuels of decreasing coal loading. Higher water vapor concentrations lowers flame temperatures, which have a strong influence on system carbon conversion. The particulate emissions for tests with the low coal loading fuels was more than three times higher than Test No. 49. The particulate emissions include all unbumed carbon and so carbon conversion and particulate emissions are strongly coupled. It should be noted that these data have been uncorrected for equivalence ratio which presents a problem in comparing the results. This is true more for the data taken in Test No. 50 in which the average equivalence ratio was 1.55. Typically, carbon conversion should decrease as primary equivalence ratio is increased past some critical value in the range of 1.5 to 1.75. However, this value has not been established for the TSSC.

The particulate ash and dilution water analyses are also included in Table 3 for the three tests. The ash analyses of the particulate usually reflect the ash composition of the coal burned. This trend is not reflected in the data presented in Table 3 in that $\mathrm{Fe}_{2} \mathrm{O}_{3}$ is the largest constituent for two of the tests (48 and 49) whereas in the coal ash $\mathrm{SiO}_{2}$ is the major constituent. However, the three major constituents in the particulate ash analysis of $\mathrm{AL}_{2} \mathrm{O}_{3}, \mathrm{Fe}_{2} \mathrm{O}_{3}$, and $\mathrm{SiO}_{2}$ are also the major constituents in the coal ash. The dilution water analysis indicates the presence of sulfur, metal lons from the ash, and dissolved alkalls.

The last combustor performance parameter is shown in Table 1 under the heading ash balance. The primary zone slag capture is the amount of coal ash separated by the impactor in the slagging combustor. In the TSSC the primary zone slag capture has varied from $10 \%$ to $85 \%$. The combustor typically operates with a slag capture in the range of 55 to $70 \%$. The values in Table 1 are substantially lower due to the reduced length of the primary zone. Typically, the primary zone is 24 inches from injector tip to impactor. In these tests the primary zone length was reduced to 16 inches. This reduction was necessary to accommodate the water quenched slag pit for on-line slag removal. In comparing results from these tests taken with varying coal loading the highest capture was achieved with the baselline fuel with the median coal loading. The accuracy of the slag capture is $\pm 10 \%$ so determining any trend from the data in Table 1 is difficult. The data does suggest that the influence of coal loading on slag capture is not great.

Table 1 also includes the percentage ash emitted. This value is calculated from the particulate sample analysis. The primary zone slag capture and ash emission should balance to account 
for all the slag put into the system. Unfortunately, two factors introduce error in this mass balance. First, in the TSSC without a PRIS a considerable portion of ash is frozen in the secondary combustor. Determining the amount of slag trapped in this region was not completed as it would have required a complete rig tear down. Secondly, the measurement of primary zone slag capture and ash emission are accurate to within only $10 \%$ so a potential $20 \%$ measurement error is present. The imbalance in the mass balance is included in Table 1 as both a percentage of the ash input and the weight of the unaccounted for ash. The worst data balance was obtained with the basellne fuel in Test No. 48. Determining a trend in slag capture with coal loading is not possible with the data presented.

In summary, three tests have been completed with CWMs of varying coal loadings from 50 to 58.2\%. The TSSC was capable of utilizing all three fuel with little noticeable impact on combustor performance. The coal loading had a substantial impact on the fuel theology with the CWM of highest loading being more difficult to handle. The emissions varied only slightly with $\mathrm{NO}_{\mathrm{x}}$ emissions increasing with increasing coal loading. Combustor outlet temperature also increased with increasing coal loading. Carbon conversion was determined to increase slightly with increasing coal loading. The primary zone slag capture is not strongly influenced by coal loading.

\section{Ash Concentration}

The influence of coal ash on combustor performance has been investigated in three tests with CWMs "S1", "S6", and "S7" with coal ash loadings of 3.80, 8.84, and 12.81\%, respectively. The properties of the three CWMs and the tests (Nos. 48, 51, and 52) they were used in are included in Table 16. The fuels were formulated to possess similar properties with the exception of coal ash loading. This goal was achieved to a large extent, but completely uncoupling changes to the ash loading from all the other CWM properties is not possible. In particular, heating value, volatile content, and fixed carbon all decrease with increasing coal ash concentration. The decrease of the latter two are a direct result of increased ash displacing volatiles and carbon. The heating value drops due to coal ash (without any heating value) displacing the carbon and volatiles (combustible). The composition of the ash does not vary significantly as the coricentration in the coal is increased.

The combustor exhiblted good operation with all three fuels. The combustor tests were operated at nearly identical conditions as listed in Table 1. Testing is completed in the subscale TSSC with the continuous slag removal system employing a water quench bath with a lock hopper in a conical primary zone combustor with the baseline injector configuration. The slag tap torches were operated continuously throughout all three tests. The operating parameters included in Table 1 are similar for the three tests.

The largest variation in test conditions was in primary zone equivalence ratio. The tests were to be operated at an equivalence ratio of 1.38. The discrepancy stems from the additional fuel input through the slag tap torches.

The operation of the combustor was similar in the three tests being discussed. The TSSC design is tolerant to a three-fold increase in coal ash concentration without any III effects on combustor performance. In Test 52 with the highest ash loading more frequent adjustments to the rig back pressure valve were required. The back pressure valve is used to control the combustor pressure. Adjustments to this valve are required as alr flow rate, gas temperature, particulate 
loading, and quench water flow rate vary. During Test 52 (highest ash concentration) the increased adjustments to the valve were perceived to be caused by the increased ash emissions from the TSSC. Analysis of the particulate sample taken during that test do not support that perception because the particulate emissions were determined to be lower than in the other tests.

The outlet temperature measured in the three tests was uniform and nearly constant at an average near $1970^{\circ} \mathrm{F}$ as shown in Table 1. This trend is further illustrated in Figure 5, which is a plot of outlet temperature versus equivalence ratio for Tests 48,51 , and 52 . The outlet temperature is measured at the exit of the secondary combustor. The table and figure indicate that coal ash concentration over the range of 3.7 to $12.8 \%$ has no influence on outlet temperature.

Emissions are summarized in Table 1 and in Figure 6. The values in Table 1 are averaged over the entire test. Emissions of $\mathrm{CO}$ were below 15 ppmv @ $15 \% \mathrm{O}_{2}$ for all fuels tested. $\mathrm{SO}_{2}$ emissions are a function of the sulfur loading of the fuel as nearly all the sulfur input into the combustor in the fuel is converted to $\mathrm{SO}_{2}$. Therefore, neither $\mathrm{CO}$ or $\mathrm{SO}_{2}$ emissions are influenced by coal ash concentration over this range of test conditions. Lkewise, the emissions of $\mathrm{NO}_{x}$ are not influenced by ash concentration. Figure 6 is a graph of $\mathrm{NO}_{\mathrm{x}}$ emissions versus equivalence ratio for the three different coal ash concentrations. Test Nos. 48 and 43 were completed with the same CWM ("S1"), but in Test 43 the slag tap torches were not in operation. Figure 6 indicates that $\mathrm{NO}_{\mathrm{x}}$ emissions are not influenced by coal ash concentration significantly. Data included from Test 43 shows the influence of the slag tap torches rather than the coal ash loading.

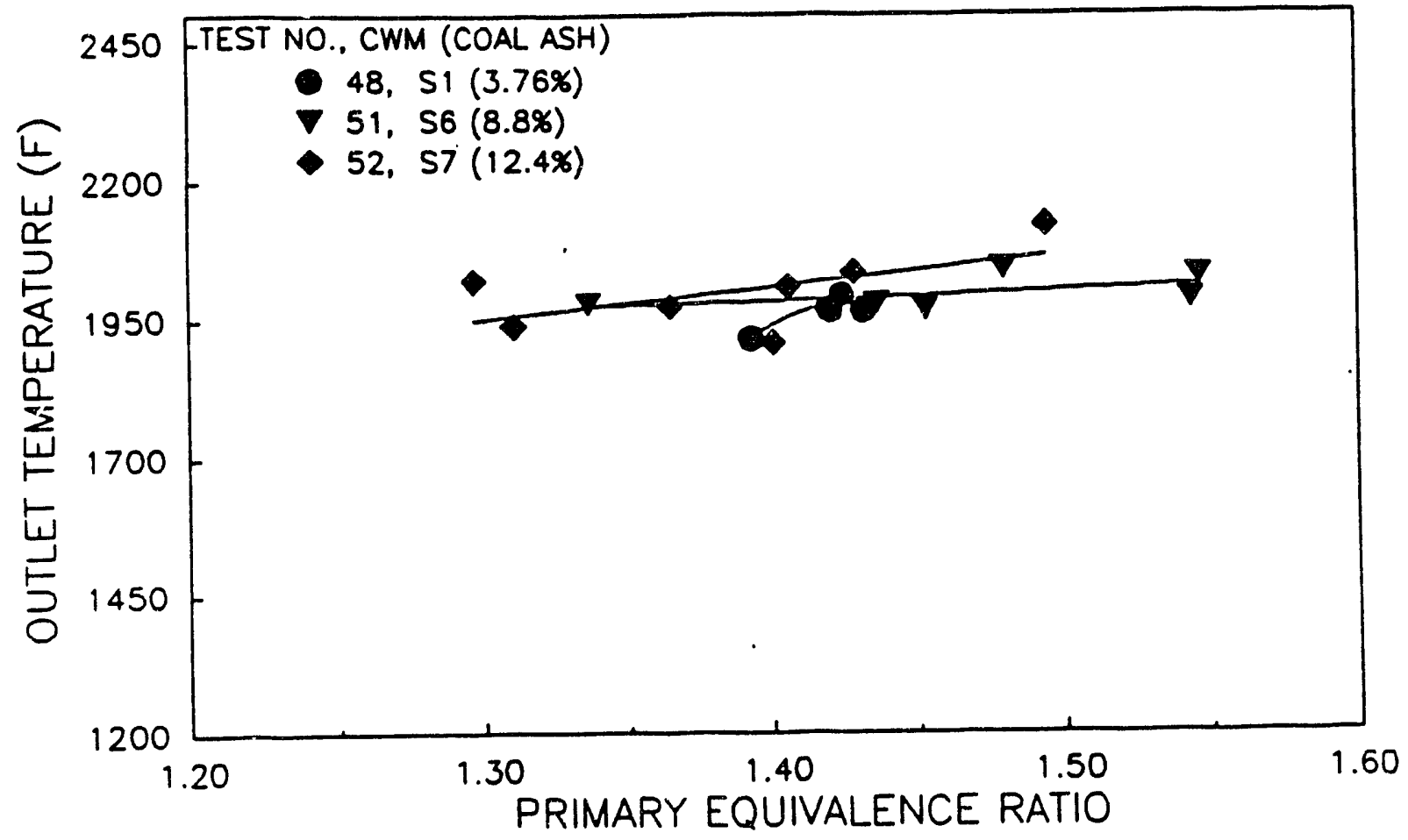

Figure 5. Varlation of Outlet Temperature With Fuels of Varylng Coal Ash Concontration 


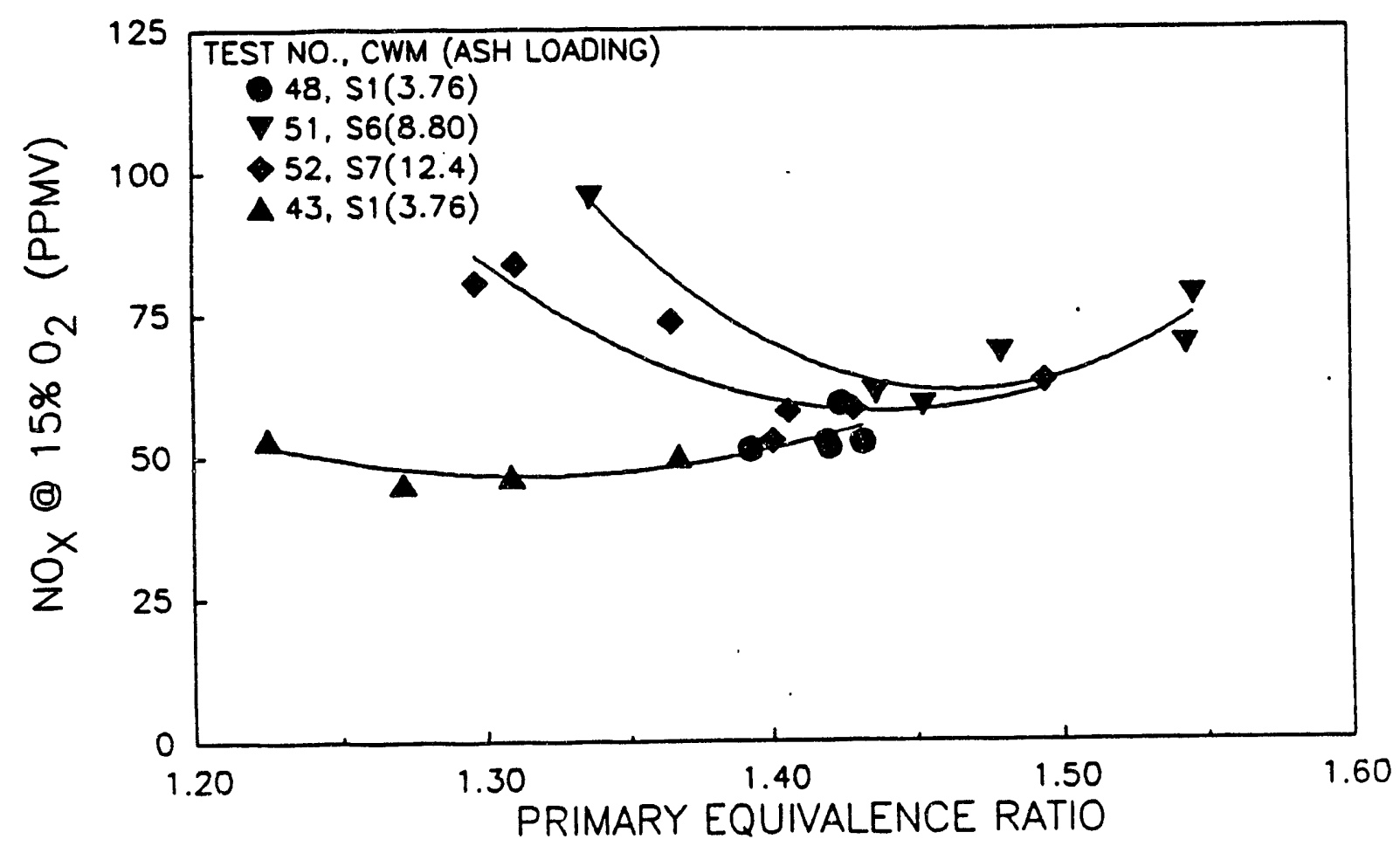

Figure 6. Variation of NO Emissions With Fuels of Varying Coal Ash

Post-test inspection of the combustor after each of the three tests revealed that as coal ash concentration is increased slag coatings and accumulations increase. In Test 48 the combustor was lightly coated with slag and little slag reached the water bath below the slag tap. After Tests 51 and 52 increasing slag accumulations were seen particularty below the slag tap. In both cases slag did not fully reach the water bath, rather froze/bridged across the insulation located between the slag tap and water bath. The amount of slag below the slag tap after each test was roughly proportional to the ash concentration of the CWM bumed. The slag below the slag tap increased from 7.2, 16.5, and $45.4 \mathrm{lbs}$ for Tests $48(3.7 \%), 51(8.8 \%)$, and $52(12.8 \%)$, respectively. The secondary combustor had increasing slag accumulations with increasing ash concentration that were visually obvious.

The higher ash coal led to an apparent greater damage to the refractory. The casting in the combustor was reused for all three tests. The inner refractory used in the combustor is a high density alumina-silica castable - Thermal Ceramics Kaocrete HPM 90. The degradation of this material was noticeably escalated as the coal ash concentration was increased. The degradation was typical of the refractory damage observed after many tests completed with the TSSC. The refractory over a number of tests first, cracks, then plts, and finally erodes to the point where recasting is required. The higher ash loading did accelerate this damage. These tests illustrate that the amount of slag the refractory is exposed to has an influence on its life. Furthermore, these results suggest that the amount of slag may be the predominant factor controlling refractory iffe. 
The particulate samples, included in Table 3, Indicate that the most efficient combustion was completed buming "S7" with the highest coal ash. The carbon conversion is the highest with that fuel at $99.7 \%$ and the particulate emissions are the lowest. CWMs "S1" and "S6" with decreasing ash concentration exhibited decreasing carbon conversions at 99.0 and $97.2 \%$, respectively. This trend suggests that coal ash actually improves combustion efficiency. One explanation of this measurement is that ash may act to break apart burning coal particles, so that, increasing coal ash results in greater coal fragmentation into finer coal particles during the combustion process. Finer coal particles would then be completely combusted in a significantly reduced residence time.

The particulate ash and dilution water analyses are also included in Table 3 for the three tests. The ash analyses of the particulate usually reflects the ash composition of the coal bumed. This trend is refiected in the data presented in Table 3. The three major constituents in the particulate ash analysis of $\mathrm{Al}_{2} \mathrm{O}_{3}, \mathrm{Fe}_{2} \mathrm{O}_{3}$, and $\mathrm{SiO}_{2}$ are also the major constituents in the coal ash. In Tests 51 and 52 these constituents are present in the same order of increasing concentrations for both the particulate and coal ash analyses. The dilution water analysis shows the presence of sulfur, metal lons from the ash, and dissolved alkalis.

The last combustor performance parameter is shown in Table 1 under the heading ash balance. The primary zone slag capture is the amount of coal ash separated by the impactor in the slagging combustor. In the TSSC the primary zone slag capture has varied from $10 \%$ to $85 \%$. The combustor typically operates with a slag capture in the range of 55 to $70 \%$. The values in Table 3-1 are substantially lower due to the reduced length of the primary zone. The accuracy of the slag capture measurement is $\pm 10 \%$ for the low ash coal but improves as the ash concentration is increased. This improvement results from increased slag weight measurements relative to the accuracy of the scale, which are used to determine the slag capture. The data suggests that coal ash concentration Improves primary zone slag capture.

The particulate emission measurements included in Table 1 support this conclusion that increasing coal ash concentration improves primary zone slag capture. This measurement shows the highest particulate ernissions (2034 ppmm) being measured with the baseline fuel that contains the lowest coal ash. In general, the higher the particulate emissions the lower the slag capture. This is obvious when considering an ash mass balance in the system. Ash not captured as slag in the primary zone is elther emitted from the combustor in the form of particulate ash or frozen in the system between the primary zone and exhaust. In Tests 48, 51, and 52 the particulate emissions decrease with increasing coal ash concentration, which suggests that the slag capture should increase. Both the particulate measurements and the slag capture measurements support this observation.

The error in the mass balance is included in Table 1 as both a percentage of the ash input and the weight of the unaccounted for ash. The worst data balance was obtained with CWM "S6" with the medium ash level.

In summary, three tests have been completed with CWMs of varying coal ash concentrations from 3.7 to $12.8 \%$. The TSSC was capable of utilizing all three huels with little noticeable impact on combustor performance. The CWMs all exhibited similar handling propertles. Gaseous emissions were not influenced by coal ash concentration. Carbon conversion was determined to increase with increasing coal ash concentration. The primary zone slag capture, although large measurement errors exist, did appear to improve as coal ash concentration was increased. 
Higher coal ash resulted in faster refractory degradation and larger accumulations of slag in the secondary combustor.

\section{No Additives}

CWM "S5" was blended without the addition of the fuel additives normally Included. The properties of this CWM are included in Table 16. This fuel contains no dispersant (A-23) or stabilizer (Flocon). Studles at Sandia Laboratory have found that these additives inhibit CWM atomization. By alding the atomization process an improvement in combustion performance should be realized. The fuel also difiers from the baseline CWM ("S1") in several other ways. The coal grind has a bimodal distribution, which is shown through an increased mean size. The coal loading is substantially lower than in the baseline with a resulting lower heating value. The CWM was intentionally blended with these properties as a potential hybrid CWM. The CWM was blended and shelved for approximately 10 months.

The operating conditions and major results for this test are included in Table 1. In Test 53 the combustor was operated at standard conditions with a slightly lower equivalence ratio. In general, the combustor exhibited below average performance. In particular, the $\mathrm{CO}$ emissions were higher and the slag capture was substantially lower. Another indication of poor combustor performance was the large amount of char found in the water bath after the test. While mixing the CWM, a thick "gelatin" Ilke quality was noted. The thickened fuel caused a higher than normal fuel pump pressure and eventually led to a clog in the CWM delivery line upstream of the mass flowmeter. The clog forced an early shut-down of the test.

The thickened appearance of the CWM is not supported by the viscosity measurements made after the fuel was prepared. In Table 16 a viscosity of $375 \mathrm{cp} @ 100 / \mathrm{sec}$ is listed. While this value is slightly higher than the typical specification of $300 \mathrm{cp}$, the viscosity measurement does not corroborate with the CWM "gelatinatious" appearance. Without the addition of an antibacterial agent the CWM may have been altered biologically while sitting for the past 10 months, but tests of the CWM showed no abnormalities.

The particulate sample taken in this test has been analyzed and data is included in Table 1 and 3. The carbon conversion is in-line with other tests and the particulate emissions are slightly improved. These results are slightly contradictory to the above statements that the combustor exhibited poorer performance than other tests.

In conclusion, a CWM with no additives has been tested and exhibited poorer combustion performance. The CWM appeared to be substantially thicker than other fuels tested leading to a clog in the fuel delivery line.

\section{Coal Particle SIze}

The influence of coal particle size on combustor performance has been investigated in three tests with CWMs "S1", "S8", and "S9" with coal particle top-sizes of 45, 25, and 75 microns, respectively. The properties of the three CWMs and the tests (Nos. 48, 54, and 55) they were used in are included in Table 16. The fuels were formulated to possess similar properties with the exception of coal particle size. This goal was achieved to a large extent. 
The combustor exhiblted good operation with all three fuels. The combustor tests were operated at nearty identical conditions as listed in Table 1. The operating parameters included in Table 2 are similar for the three tests.

The largest variation in test conditions was in primary zone equivalence ratio. The tests were to be operated at an equivalence ratio of 1.38. The discrepancy stems from the additional fuel input through the slag tap torches.

The operation of the combustor was similar in the three tests being discussed. The TSSC design is tolerant to a three-fold increase in coal particle top-size without any ill effects on combustor performance. Test 55 was a slightly smoother test than either of the other tests in terms of combustor outlet temperature and pressure and the need for back pressure valve adjustment. The back pressure valve is used to control the combustor pressure. Adjustments to this valve are required as alr flow rate, gas temperature, particulate loading, and quench water flow rate vary.

The outlet temperature measured in the three tests was fainty uniform at an average of $2000^{\circ} \mathrm{F}$ as shown in Table 1. This trend is further illustrated in Figure 7, which is a plot of outlet temperature versus equivalence ratio for Tests 48,54 , and 55 . The outlet temperature is measured at the exit of the secondary combustor. The table and figure indicate that coal particle top-size over a range of $\mathbf{2 5}$ to $\mathbf{7 5}$ microns has no detectable influence on outlet temperature over a variation of primary equivalence ratio of 1.3 to 1.7 .

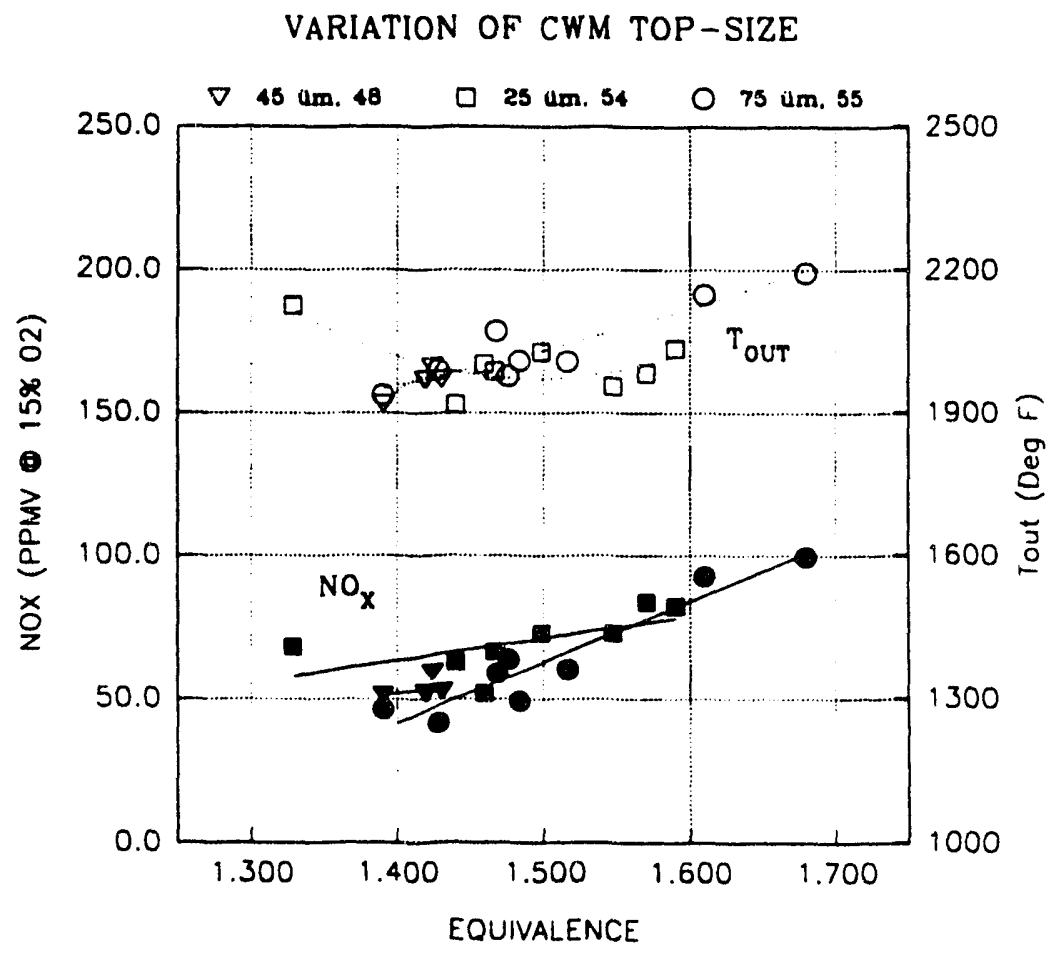

Fgure 7. Outlet Temperature and Emission Characteristlcs of TSSC Burning CWMs Made From Coals of Varying Particle Slze 
Emissions are summarized in Table 1 and in Figure 7. The values in Table 1 are averaged over the entire test. Emissions of $\mathrm{CO}$ were below 20 ppmv @ 15\% $\mathrm{O}_{2}$ for all fuels tested. $\mathrm{SO}_{2}$ emissions are a function of the sutfur loading of the fuel as nearly all the sulfur input into the combustor in the fuel is converted to $\mathrm{SO}_{2}$. Therefore, neither $\mathrm{CO}$ or $\mathrm{SO}_{2}$ emissions are influenced by coal particle size over this range of test conditions. Figure 7 is a graph of $\mathrm{NO}_{x}$ emissions versus equivalence ratio for the three different coal particle sizes. Figure 7 indicates that $\mathrm{NO}_{x}$ emissions are not influenced by coal particle size significantly.

Post-test inspection of the combustor after each of the three tests revealed that coal particle topsize variations of 25 to 75 microns has no noticeable impact on slag coatings and accumulations. In the three tests being compared the combustor was lightly coated with slag and little slag reached the water bath below the slag tap. Accumulations of slag in the secondary combustor were light.

Analysis of particulate samples have been completed to provide the carbon conversion and particulate emissions data included in Table 1. The analysis of the three samples is included in Table 3. The particulate samples Indicate that the most efficient combustion was completed burning "S9" with the largest coal particle top-size. The carbon conversion with that fuel is the highest at $98.5 \%$ and the particulate emissions are the lowest. CWM's "S1" and "S8" with consecuttively finer grinds exhibited carbon conversions of 97.2 and $97.9 \%$, respectively. The data does not show a distinct trend with coal particle size. Given the small variations in carbon conversion these results may reflect measurement errors. An alternative explanation assuming that the carbon conversion does vary as indicated may come from an examination of the atomization process. It has been surmised that CWM atomization is improved by a mix of small and large particles, rattier than all small particles. If a mix of large and small particles can be atomized more finely than a fluid containing only small particles then the carbon conversion should trend with the size of the droplets generated rather the size of the coal particles.

The particulate ash and dilution water analyses are also included in Table 3 for the three tests. The ash analyses of the particulate usually reflect the ash composition of the coal burned. This trend is reflected in the data presented in Table 3. The three major constituents in the particulate ash anatysis of $\mathrm{Al}_{2} \mathrm{O}_{3}, \mathrm{Fe}_{2} \mathrm{O}_{3}$, and $\mathrm{SiO}_{2}$ are also the major constituents in the coal ash. In Tests 54 and 55 these constituents are present in the same order of increasing concentrations for both the particulate and coal ash analyses. The dilution water analysis shows the presence of sulfur, metal ions from the ash, and dissolved alkalis.

In comparing ash balance results from these tests taken with varying coal particle size the nighest slag capture was achieved with the CWVM of a medlum coal grind (45 microns). The accuracy of the slag capture measurement is $\pm 10 \%$ for the CWM's tested. Both the fine and coarse coal grinds had similar slag capture efficiencies. The decrease in slag capture with either increasing or decreasing coal particle size from $\mathbf{4 5}$ microns is not fully understood. Measurement error could certainly contribute to these findings. This result can also be explained by the influence of particle size on atomization as discussed in the previous section.

In summary, three tests have been completed with CWMs of varying coal particle top-size of 25 to 75 microns. The TSSC was capable of utilizing all three fuels with little noticeable impact on combustor performance. The CWMs all exhibited similar handling properties. Gaseous emissions were not influenced by coal particle size. Carbon conversion is only weakly influenced by coal 
particle size with the highest conversion obtained with the largest top-size. The primary zone slag capture, although large measurement errors exist, did appear to get worse as coal particle topsize was increased or decreased from 45 microns.

\section{Coal Seams}

The difference in combustor pertormance with CWM's made from four different coal seams has been investigated in four tests with CWMs "S1", "S10", "S11", and "S12". These mixtures have been produced from coals taken from the Kentucky 4AElkhom, Upper Freeport, Soldler Creek, and Illinois No. 6. seams, respectively. These seams are potential sources of coal for the coalfueled Centaur sited in different regions of the country. The properties of the four CWMs and the tests (Nos. 48, 56, 57, and 58) they were used in are included in Table 16. The fuels were formulated to possess similar properties with the exception of the c.jal seam used to produce the slumy. The coal seam has a substantial impact on fuel properties. In particular, these seams show significant varlations in volatile content and ash loading. A more complete comparison of the fuels is included in Section 5.2.

The combustor exhibited good operation with all four fuels. The combustor tests were operated at nearly identical conditions as listed in Table 1. The operation of the combustor was similar in the four tests being discussed. The TSSC design is capable of utilizing bituminous coals from different coal seams located in different regions of the country. The pinciple differences in operation of the combustor with these fuels occurred in Tests 56 and 58 . In Test 56 the back pressure valve required more frequent purges. With CWM "S10" the increased ash loading of the coal lead to the increased number of purges. During Test 58 the fuel exhibited poorer fuel pumping characteristics with variations of plus/minus $7.6 \%$. Analysis of the fuel sampled at the combustor inlet has indicated rather standard properties. The fuel pump has operated normally in subsequent tests. A heavier build-up in the fuel filters was noted at the conclusion of Test 58. This blockage is the probable cause of the fluctuations in the fuel fiow rate. A more robust feed system could be designed to adequately dellver CWM "S12".

The outlet temperature measured in the four tests was fairly uniform at an average of $1979^{\circ} \mathrm{F}$ as shown in Table 1. This trend is further lliustrated in Figure 8, which is a plot of outlet temperature versus equivalence ratio for Tests $48,56,57$, and 58 . The outlet temperature is measured at the exit of the secondary combustor. The table and figure indicate that the coal seam has little influence on outlet temperature. The highest temperatures on average resulted from the Upper Freeport coal which has a medium volatile content of $25.8 \%$ versus 35 to $39 \%$ for the other coals. This coal also exhibited the highest carbon conversion at $99.8 \%$ which should result in a higher outlet temperature.

Emissions are summarized in Table 1 and in Figure 8. The values in Table 1 are averaged over the entire test. Emissions of $\mathrm{CO}$ were below 25 ppmv @ 15\% $\mathrm{O}_{2}$ for all fuels tested. $\mathrm{SO}_{2}$ emissions are a function of the sulfur loading of the fuel as nearly all the sulfur input into the combustor in the fuel is converted to $\mathrm{SO}_{2}$. Therefore, neither $\mathrm{CO}$ or $\mathrm{SO}_{2}$ emissions are influenced significantly by coals taken from different coal seams. Ukewise, the emissions of $\mathrm{NO}_{\mathrm{x}}$ are not influenced by these coals from different bltuminous seams. Figure 8 is a graph of NO $\mathrm{x}_{\mathrm{x}}$ emissions versus equivalence ratio for the four different coal seams. Figure 8 indicates that $N_{x} \theta$ missions are not influenced by coals from different seams significantly. 


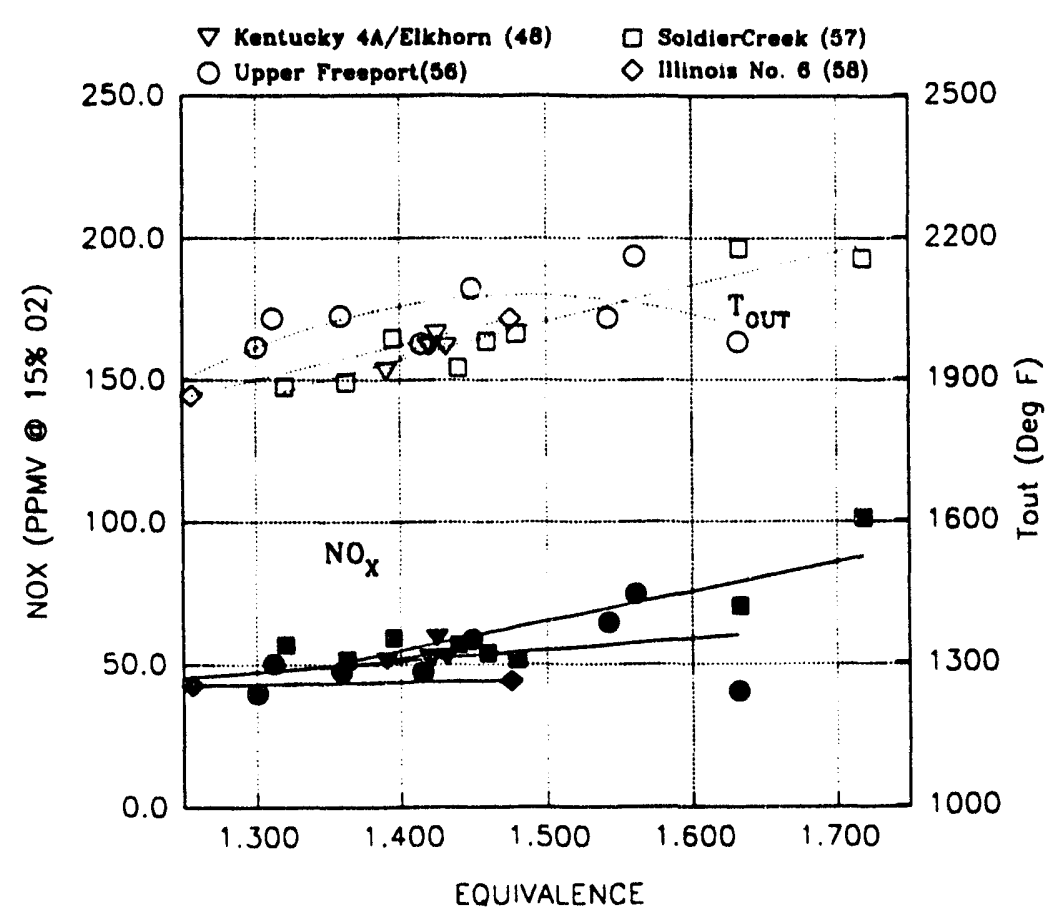

Figure 8. Outlet Temperature and Emisslon Characterlstles of TSSC Burning CWMs Made From Coals From Different Seams

Post-test inspection of the combustor after each of the four tests revealed that the slag coatings are a strong function of the ash content of the coal. Tests 48,57 , and 58 all had light coatings on the primary zone wall and in the secondary combustor, while in Test 56 the slag coatings and accumulations are heavier particularly in the secondary combustor. In Test 58 a greater slag capture in the primary zone was demonstrated.

The particulate sample analyses in Table 3 indicate that the most efficient combustion was completed buming "S10" from the Upper Freeport seam. The carbon conversion is the highest with that fuel at $99.8 \%$ and the particulate emissions are the lowest. The CWMs made from the coals from the different coal seams all bumed with carbon conversions above $98 \%$, higher than the baseline coal at $97.2 \%$.

The particulate ash and dilution water analyses are also included in Table 3 for the three tests. These data show typical trends of the ash composition reflecting the composition of the particulate ash.

Comparing ash balance results presented in Table 1 from these tests taken with coals from different seams the highest slag capture was achieved with the coal from the Illinois No. 6. The accuracy of the slag capture measurement is $\pm 10 \%$ for the CWM's tested. The other seams demonstrated slag captures ranging from 23 to $37 \%$. The slag capture values reported in Table 1 trend most significantly with the $\mathrm{F}_{2} \mathrm{O}_{3}$ content of the coal ash. Iron oxide has been found to reduce slag viscosity at constant temperature in reducing environments. In these tests where the $\mathrm{Fe}_{2} \mathrm{O}_{3}$ content varied from $20.08 \%$ (S12), $12.12 \%$ (S1), $11.92 \%(\mathrm{~S} 10)$, to $7.67 \%$ (S11) the slag captures varied from $54 \%, 37.2 \%, 31 \%$, to $23 \%$, respectively. The primary zone slag capture and ash emission should balance to account for all the slag put into the system. The error in the mass balance is included in Table 2 as both a percentage of the ash input and the weight of the unaccounted for ash. The worst data balance was obtained with CWMs "S10" and "S11". 
In summary, four tests have been completed with CWMs made from coals from different coal seams. The coal seams used are a Kentucky 4AElkhom blend, Upper Freeport, Soldier Creek, and IIlinois No. 6. All four seams are bituminous coals that potentially will be supplles for the Coal-Fueled Centaur as it is stted in different regions of the country. The TSSC was capable of uttlizing all four fuels with little noticeable impact on combustor performance. The CWMs exhiblted similar handling properties except for the slumy from the Illinois No. 6 seam which was more difficult to pump. Gaseous emissions were not influenced by the coal seam. The highest carbon conversion was obtained with the coal from the Upper Freeport seam which has the lowest volatile content. The primary zone slag capture, although large measurement errors exist, was highest with the Illinois No. 6, which had the highest Iron content in the ash.

\section{Coal Fud Specilleation}

Testing conducted in the TSSC to study the Inftuence of fuel properties on combustor performance has been completed to design a tuel speclification for the F/S combustor. The design goal of the TSSC is to make a system that could use an extremely large range of fuel properties. The test results indicate that the design goal has been met.

Testing has indicated that the combustor can efficiently bum slumies with coal loadings ranging from 49.9 to $58.2 \%$, ash content of 3.8 to $12.8 \%$, coal particle top-size of 25 to 75 microns, and bitumenous coals from a large number of seams located regionally in the U.S. The tests have indlcated that only high coal loading and CWMs formulated without any additives severely impact the combustor performance. Fuels ith high coal ash load ot faster refractory damage, but do not impact combustor promance while the refractory is intact.

Based on these test rsults and all earlier tests, the fuel specification for full scale combustor tesitng has been set and is included in Table 15. These tuel properties do not represent limits for ash concentralton, coal laoding, etc., but are hte fuel properties that have consistently yielded the best system performance results. The fuel specification for the coal-fueled engine has not yet been fully determined. with the results obrtained in this study, It is known that the combustor can be fueled with a considerably broader range of CWM properties than have been used in the past.

\section{2 .2 Full Scale Combustor Testing}

Testing of the full scale combustor is being completed independently of the engine at the Caterpillar Technical Center in Peoria, III. The entire combustor island which includes the primary combustor, PRIS, and secondary combustor installed together as Illustrated in Figure 9 will be tested later in this test series. The firet series of tests are being completed without the PRIS. The test set-up including the primary and secondary combustors installed at the Tech Center are included in Figure 10 as a photograph and in schematic form in Figure 11.

The facility is capable of providing 25.0 pps of air flow preheated to $605^{\circ} \mathrm{F}$ and an additional 2.6 pps of unheated (but higher pressure) air for atomization. The facllity is capable of 31 pps air dellvery. The combustor will be operated at 7.0 atmospheres rather than the Centaur operating pressure of 10.0 atmospheres due to the air supply imitations. The Centaur Type H uses 39.8 pps of total air flow. The combustor hardware will be instrumented for temperature, pressure, and emission measurements using standard techniques and commercially available equipment. 


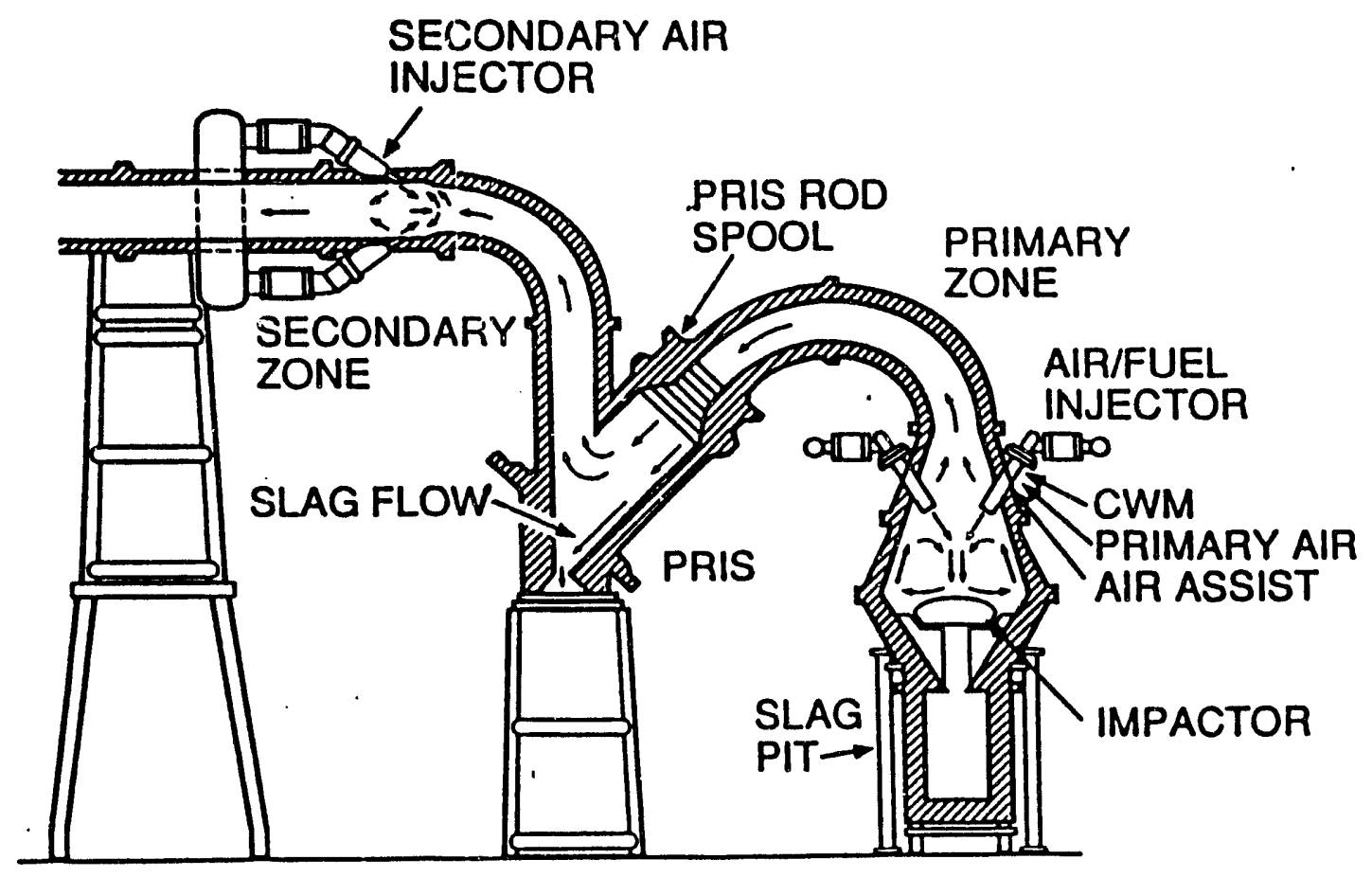

Figure 9. Combustor Island

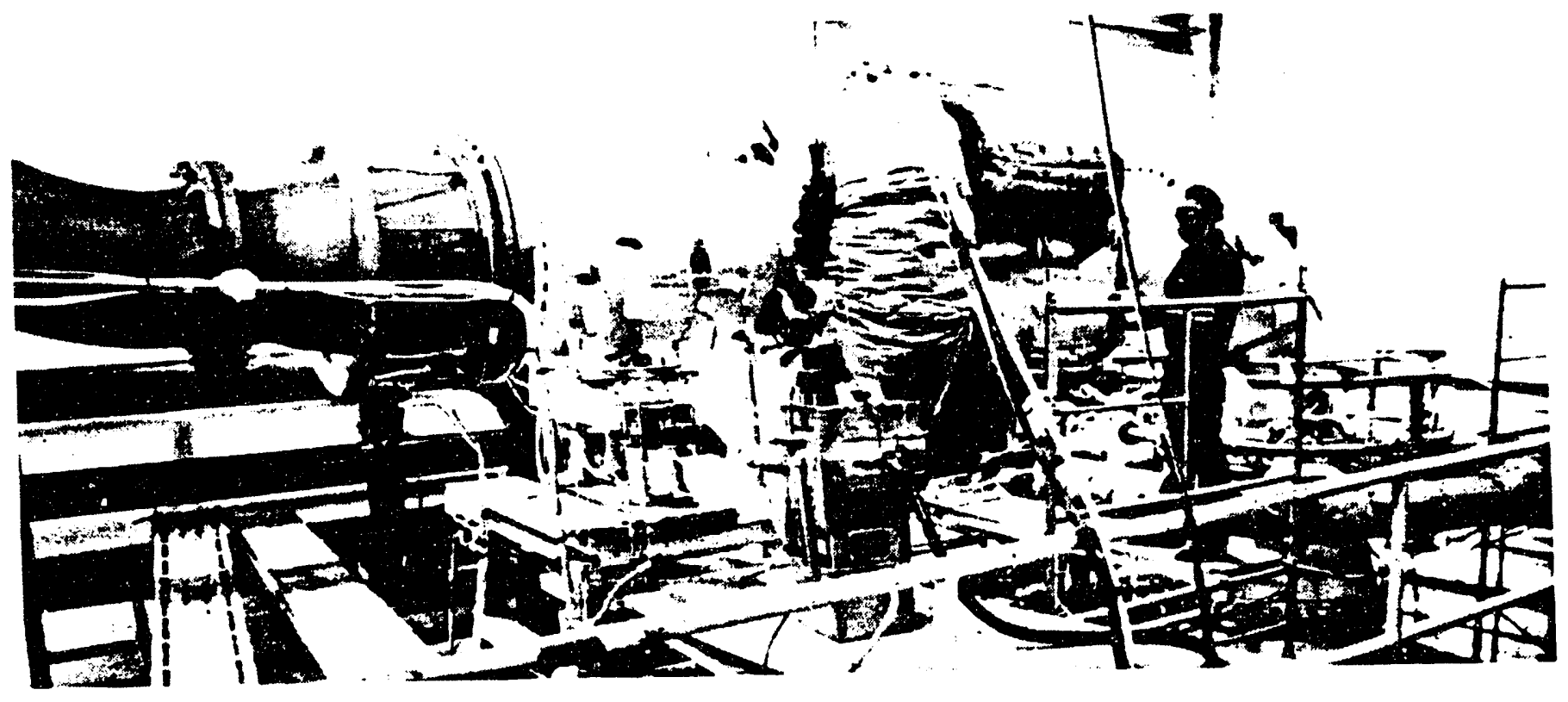

Figure 10. Test Set-Up at Caterplliar Tech Center 


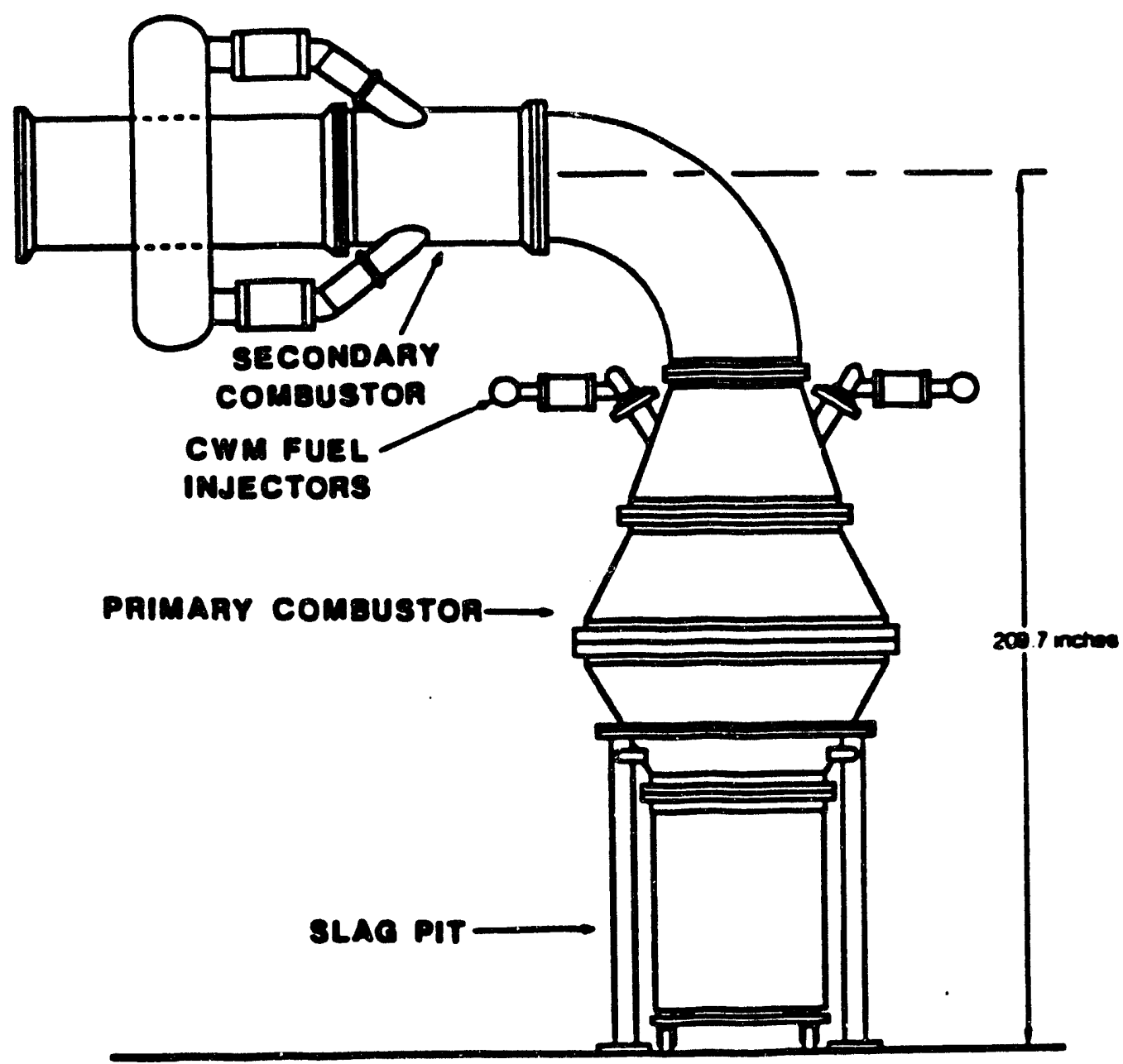

Fgure 11. Full-Scale Combutor Without PRIS

The operation and performance of the combustors will be evaluated in a series of seven combustion tests. In these tests the combustor island will be operated on diesel fuel for a 4 to 6 hour warm-up period. Refractory wall temperatures measured 1.0 inch from the inner surface of the primary combustor are monitored. When these temperatures reach $2000^{\circ} \mathrm{F}$ the combustor is switched from diesel to CWM. Upon switching to CWM all diesel fuel flow is terminated. The combustor island is operated burning CWM for 4 to 6 hours at steady conditions. These conditions are a pressure of 7 atmospheres, primary zone equivalence ratio of 1.38, air inlet temperature of $605^{\circ} \mathrm{F}$, and a combustor pressure drop ratio of $4 \%$.

When the PRIS is installed, the inlet temperature to the PRIS is monitored and not allowed to exceed $2950^{\circ} \mathrm{F}$ so as to protect the ceramic rods. This temperature is controlled by increasing or decreasing the primary zone equivalence ratio. If a major adjustment to the equivalence ratio is necessary the primary to secondary air flow split will be changed between tests so that the 
outlet temperature of the combustor can be maintained at $1900^{\circ} \mathrm{F}$. At the conclusion of the CWM test the combustor is switched over to diesel fuel again for a cool-down of 2 hours.

During operation on CWM data is taken at approximate twenty minute intervals. Along with the operational data a complete temperature and pressure map will be recorded as well as gaseous emissions and particulate samples. At the conclusion of the test after the combustor has cooled the slag capture efficiency will be determined by measuring the quantity of slag captured in the slag pits. This measurement can be checked against the ash emission rate as determined from the particulate sample. The combustor is also inspected for slag accumulations and refractory damage.

The full scale combustor has been operated in four tests without the PRIS in-line. The tests were completed to cure the refractory, shakedown the test facility burning diesel fuel, and demonstrate CWM combustion. During the initial CWM combustion test data was obtained so that the primary to secondany flow split can be adjusted. These objectives were accomplished in Test Nos. 1, 2, and 4. Operating conditions and results from all full scale tests are included in Table 4. In additior. Table 4 includes the design point operating conditions.

\section{Test 1}

The first test was ended after 21 hours of operation with hot air flowing through the combustor. The heat-up schedule is included on the graph in Figure 12. Heat-up on air up to $730^{\circ} \mathrm{F}$ went very well over the first 16 hours. A series of difficulties with the diesel dellvery system were encountered and corrected during the test over a four hour period. After completing these fixes the diesel torch was ift on the first attempt. Light-off on diesel fuel in the combustor was completed within the next ten minutes. Flange leaks in the exhaust piping upstream of the back pressure valve were observed as the quench water was increased. Significant amounts of steam venting into the test cell forced ing shut-down. Other system and test problems have been identified and were corrected.

Temperature records are the only data recorded for this test. As the graph indicates the air temperature was kept close to plan. The curing schedule was designed to maximize refractory IIfe.

\section{Test 2}

The objective of Test No. 2 was to complete the refractory curing schedule and bum diesel at test pressures up to 87.5 psig. One hour operation with CWM was planned upon successful completion of the diesel test.

The air temperature was ramped up to $730^{\circ} \mathrm{F}$ over nine hours to drive out moisture from the refractory and bring up the reiractory temperature. A temperature-time history of the test is included in Figure 13. The air temperature was dropped down to $620^{\circ} \mathrm{F}$ in preparation for diesel combustion. The torch was ignited and light-off on diesel fuel completed within ten minutes. Temperatures of the refractory ("pluses") and gases ("triangles") exiting the primary zone are included in the graph. The primary air/fuel ratio was started at 30 and decreased over three hours to 24. The pressure in the combustor was maintained at 40 psig throughout the test. The plan to increase the pressure to $87.5 \mathrm{psig}$ could not be completed due to inaccurate air flow 
Table 4. Full Scalo Combustor Test Results

\begin{tabular}{|c|c|c|c|c|c|}
\hline Test No. & Design & 1 & 2 & 3 & 4 \\
\hline Objective & - & Curing & DF No.2 & 1st CWM & 1st CWM \\
\hline Main Fuel & CWM & - & Diesel & Diesel & CWM "W" \\
\hline$T_{m}\left({ }^{\circ} F\right)$ & 620 & $400-730$ & 616 & 610 & 605 \\
\hline$P_{n}$ (psig) & 132.2 & $0-23$ & 41. & 43.8 & 61.5 \\
\hline$\phi_{\text {prtmery }}$ & 1.38 & - & $.49-.61$ & .59 & 1.33 \\
\hline$\Delta P / P(\%)$ & 4.0 & - & 4.07 & 4.20 & $4.0-3.2$ \\
\hline Heat (MMBtw/hr) & 47.5 & - & 11.3 & 11.5 & 44.8 \\
\hline$T_{\text {promery }}\left({ }^{\circ} \mathrm{F}\right)$ & 2900 & 730 & 2827 & 2751 & 2846 \\
\hline $\begin{array}{l}T_{\text {mondany }}\left({ }^{\circ} \mathrm{F}\right) \\
\text { RESULTS }\end{array}$ & 1900 & 695 & 1441 & 1363 & 1967 \\
\hline \multicolumn{6}{|l|}{ Emissions @ 15\% } \\
\hline $\begin{array}{l}\mathrm{NO}_{x} \text { (ppmv) } \\
\text { [lbm/MMBtu] }\end{array}$ & 125 & - & - & $\begin{array}{r}212.4 \\
{[2.289]}\end{array}$ & $\begin{array}{r}52.1 \\
{[0.245]}\end{array}$ \\
\hline $\begin{array}{l}\text { CO (ppmw) } \\
\text { [lbm/MMBtu] }\end{array}$ & 50 & - & - & 0 & $\begin{array}{c}31.4 \\
{[0.044]}\end{array}$ \\
\hline $\begin{array}{l}\mathrm{SO}_{2} \text { (pprmv) } \\
\text { [lom/MMBtu] } \\
\text { w/o Sorbent }\end{array}$ & $\begin{array}{c}75 \\
\text { w/Sorbent }\end{array}$ & - & - & $\begin{array}{r}27.5 \\
{[0.413]}\end{array}$ & $\begin{array}{r}171.0 \\
{[1.134]}\end{array}$ \\
\hline Part. (ppmm) & 120 & - & - & - & NA \\
\hline Carbon Conv. (\%) & 98 & - & - & - & N/A \\
\hline
\end{tabular}

measurements in the cold run of the air supply. As the figure indicates gas temperatures up to $2795^{\circ} \mathrm{F}$ were recorded with refractory temperatures up to $2375^{\circ} \mathrm{F}$. Provisions for switching to CWM were made, but after 3 hours burning diesel tuel a leak was noted in the exhaust duct downstream of the back pressure value.

The combustor was Inspected with a borescope and was found to be in excellent shape. All refractory was in "as cast" shape with only a few small cracks noted in the refractory around the injectors. 


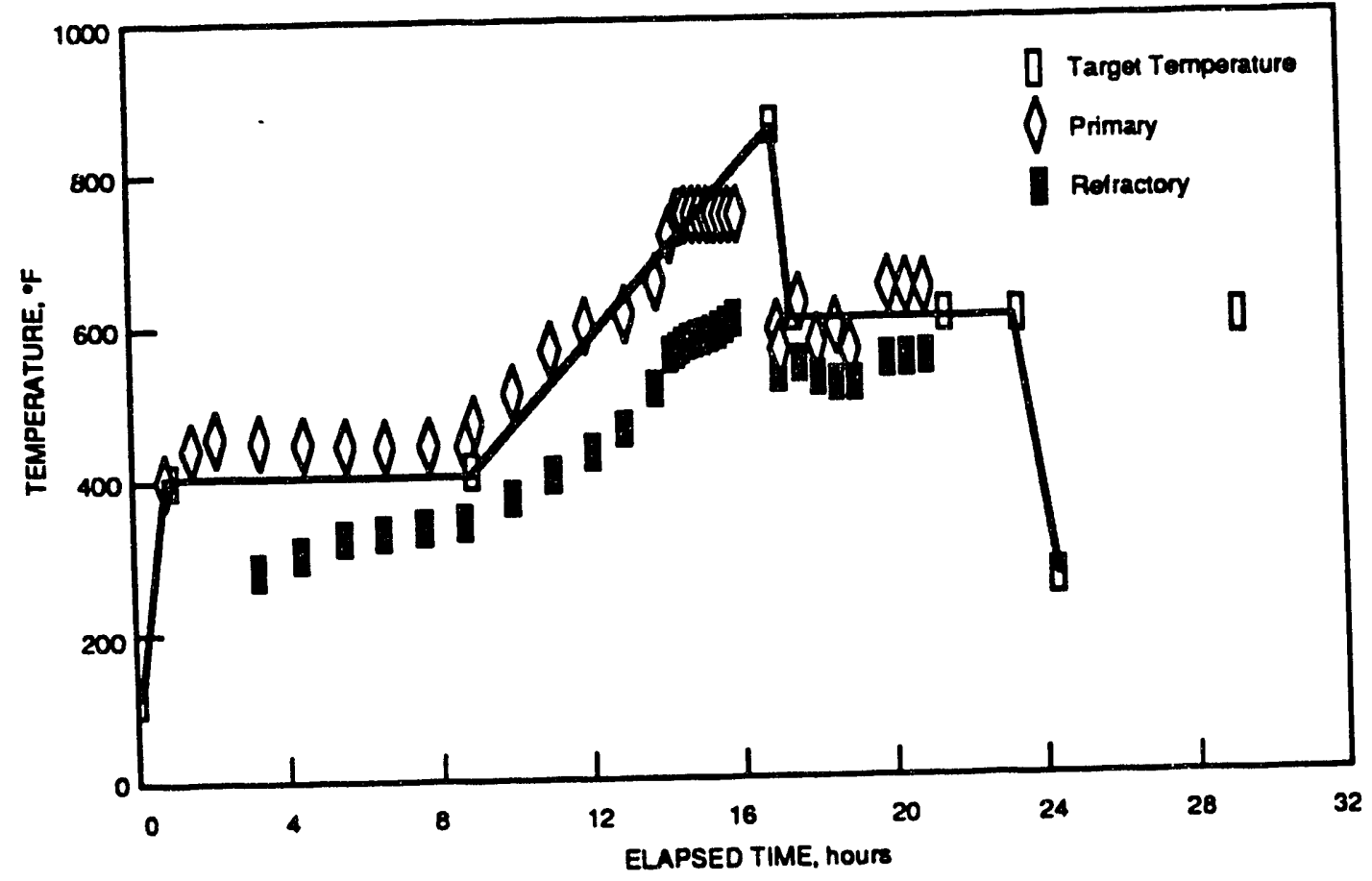

Figure 12. The Temperature History of the Full-Scale Combustor During the First Refractory Curing Diesel Test

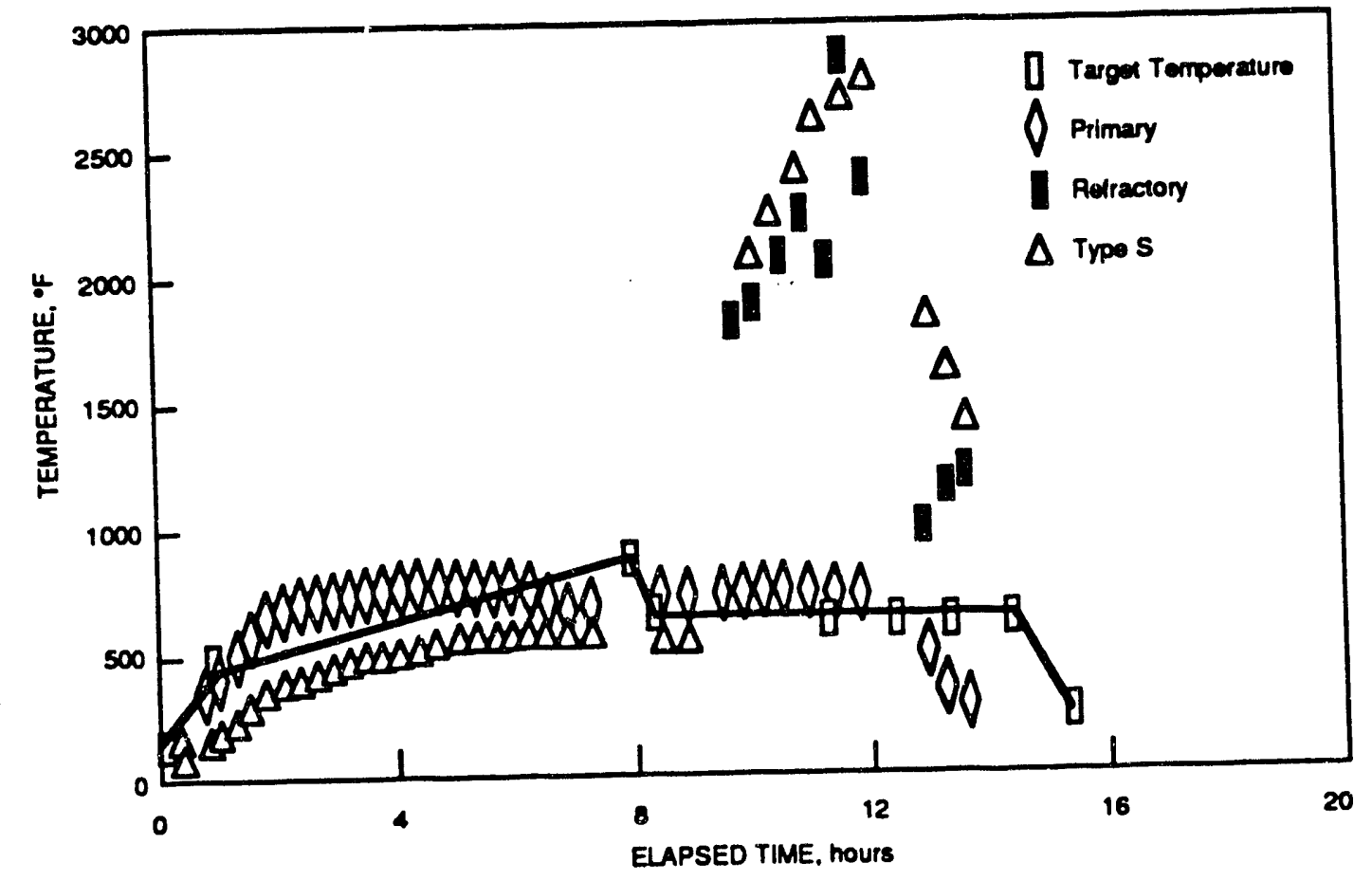

Figure 13. Temperature-Time History of F/S Combustor During Tesi No. 2 
The temperature history of the test is attached. This test has successfully completed the refractory curing process and demonstrated combustion of diesel fuel. The combustor operated smoothly with outlet temperatures reaching $1442^{\circ} \mathrm{F}$. The refractory heated faster than anticipated with less heat loss than in the subscale combustor. The primary zone gas temperature of $2800^{\circ} \mathrm{F}$ at an air/fuel ratio of 24 indicates that the heat loss has been lowered over the subscale combustor. In the subscale combustor the primary zone temperature typically is on the order of $2900^{\circ} \mathrm{F}$ at an air/fuel of 20 . Skin temperatures of the combustor remained below $230^{\circ} \mathrm{F}$ as determined by an infra-red temperature gun.

As indicated in Table 4, the primary to secondary air flow split during the test was below design at 1.6 versus 2.8. The gap in the CWM injectors for metering primary air is oversized by approximately $30 \%$ and the secondary air supply piping is undersized. A plate with a 4.33 inch bore was installed in the primary air supply leg to increase the flow split. This was a temporary solution so that the next test could be completed. To correct the problem permanently the gap on the fuel injectors must be reduced. This procedure should not be completed untl the combustor is operated buming CWM.

\section{Test Nos. 3 and 4}

The next two tests were completed to demonstrate CWM combustion for the first time. Flow data through the system while burning CWM were obtained so that the secondary to primary flow split could be adjusted. In addition, other preliminary CWM combustor performance data were obtained. Results from these tests are summarized in Table 4.

In Test 3 difficulties with the higher pressure water pump required to quench the exhaust precluded completting transfer to CWM. The air temperature was ramped up to $600^{\circ} \mathrm{F}$ and $\mathrm{rig}$ pressure increased to $40 \mathrm{psig}$. Light-off on DF\#2 was accomplished readily. A total of 4283 lbs of diesel were burned over $\mathbf{5 . 5}$ hours. The rig pressure was ramped to 60 psig and the AF in the primary zone was decreased to 23. Emissions were measured at one point. The primary zone equivalence ratio was 0.58 indicating fuel lean combustion. The outlet temperature reached a maximum of $1363^{\circ} \mathrm{F}$. The primary exhaust reached $2751^{\circ} \mathrm{F}$. Refractory temperatures in the primary zone reached $2548^{\circ} \mathrm{F}$ with an average of $1904^{\circ} \mathrm{F}$.

Test 4 was the second test completed to demonstrate CWM combustion. This test was completed with 2.5 hours of CWM combustion completed. Used in this test was CWM "W". The specifications of this fuel are included in Appendix A. The fuel has "baseline" specifications and is described in greater detail in Section 5.

During the test, the air temperature was ramped up to $600^{\circ} \mathrm{F}$ and $\mathrm{ng}$ pressure increased to 40 psig. Light-off on DF\#2 was accomplished readily. The ilg pressure was ramped to 60 psig and the AF in the primary zone was decreased to 23. The primary zone outlet temperature reached $2660^{\circ} \mathrm{F}$ on DF $\# 2$ with a secondary outlet up to $1315^{\circ} \mathrm{F}$. Transfer to CWM was completed swiftly and the diesel fuel was shut-off rapidly. The combustor ran very smoothly on CWM. The back pressure valve was fully open after operating on CWM for only several minutes. The primary zone $\triangle P / P$ started at $4 \%$ and dropped during the 2.5 hour test to 3.2 . The flow split averaged 2.33 pps of secondary air for each pps of primary air. A temperature-time history of this test is included in Figure 14. This figure inciudes temperature data from the slag pit, impactor walls, secondary combustor outlet, primary walls and the primary outlet. Figure 14 also contains the 
variation of $\triangle P / P$ during the test. The average outlet temperature was $1967^{\circ} \mathrm{F}$. The primary outlet reached $2846^{\circ} \mathrm{F}$ and averaged $2787^{\circ} \mathrm{F}$. The impactor area leading into the slag tap climbed throughout the test to $2174^{\circ} \mathrm{F}$, while the slag pit remained relatively cool with a $480^{\circ} \mathrm{F}$ maximum. CWM was stopped when a crack developed in the bellows connecting the secondary air supply pipe with the secondary air manifold. The ing was transferred back to diesel and operated an additional 0.5 hours before cool down.

Emissions were measured five times during the test and this data is included in Figure 15. This figure is a graph of $\mathrm{NO}_{x}, \mathrm{CO}$, secondary outlet, and primary outlet temperature versus primary zone oquitvalence ratio. The primary zone equivalence ratio averaged to 1.33, but due to the drop in $\triangle P / P$ fell from 1.44 to 1.13 during the test. The emissions indicate good combustion with $\mathrm{NO}_{\mathrm{x}}$ below 53 ppmv and CO below 31.4 ppmv. The CO emissions rose from 18 to 49 ppmv throughout the test while the $\mathrm{NO}_{\mathrm{x}}$ dropped from 68 to $40 \mathrm{ppmv}$. The trends of these pollutants with equivalence ratio are contrary to results obtained in subscale testing. Typically, $\mathrm{NO}_{\mathrm{x}}$ emission levels increase while $\mathrm{CO}$ emissions drop as the equivalence ratio is increased from stoichlometric (1.0) to design point (1.38). The results can be explained as an indication of a drop in combustion efficiency most likely resulting from the decreasing $\triangle P / P$. The primary and secondary outlet temperatures graphed versus equivalence ratio show the expected trends. A particulate sample taken during the test is being analyzed.

Post-test inspection of the combustor indicated some refractory problems. Most notably the impactor has broken along one edge as shown in the photograph of Figure 16. The reason the impactor has broken is believed to be insufficient support of the free hanging refractory. The impactor is supported by four refractory "ribs" resulting in a free hanging distance of over ten inches. The plan is to increase the number of support ribs to six. In addition, subscale development of a water-cooled impactor is being pursued.

The remaining refractory is coated with a relatively even coating of slag. Some spalling of the refractory is indicated in Figure 17. The injectors are in good shape, but the refractory surrounding them is already showing wear as can be seen in Figure 18. The secondary combustor, pictured in Figure 19, is showing significant slag accumulations, particularly around the secondary air nozzles. Such accumulations have been observed in subscale testing without the PRIS and were anticipated. The slag capture could not be determined because of the new refractory which tends to "soak-up" slag. No slag accumulations reached below the impactor and Into the slag pit. 


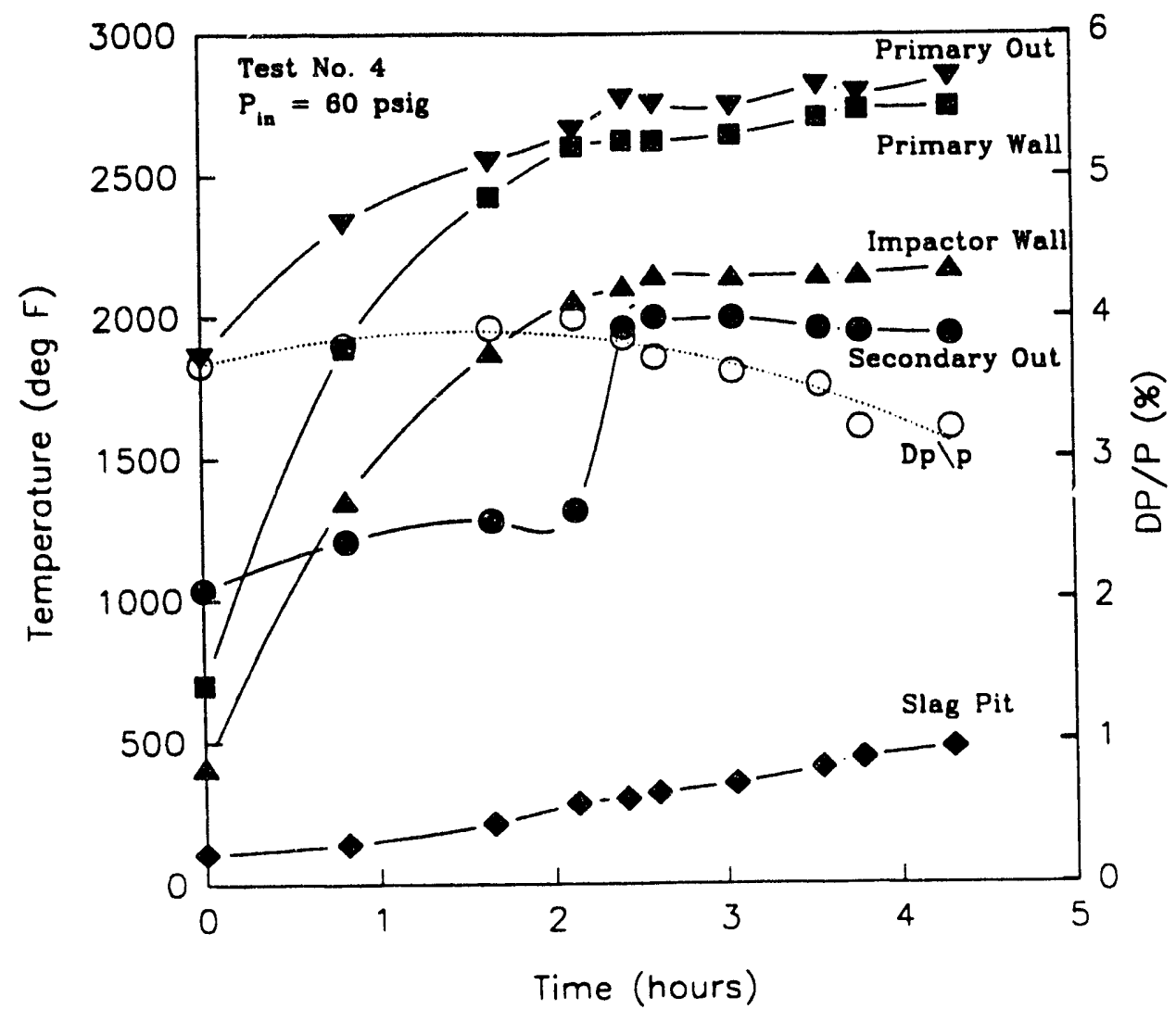

Figure 14. The Temperature-TIme History of the Full-Slze Combustor at Several Locations for Test No. 4 


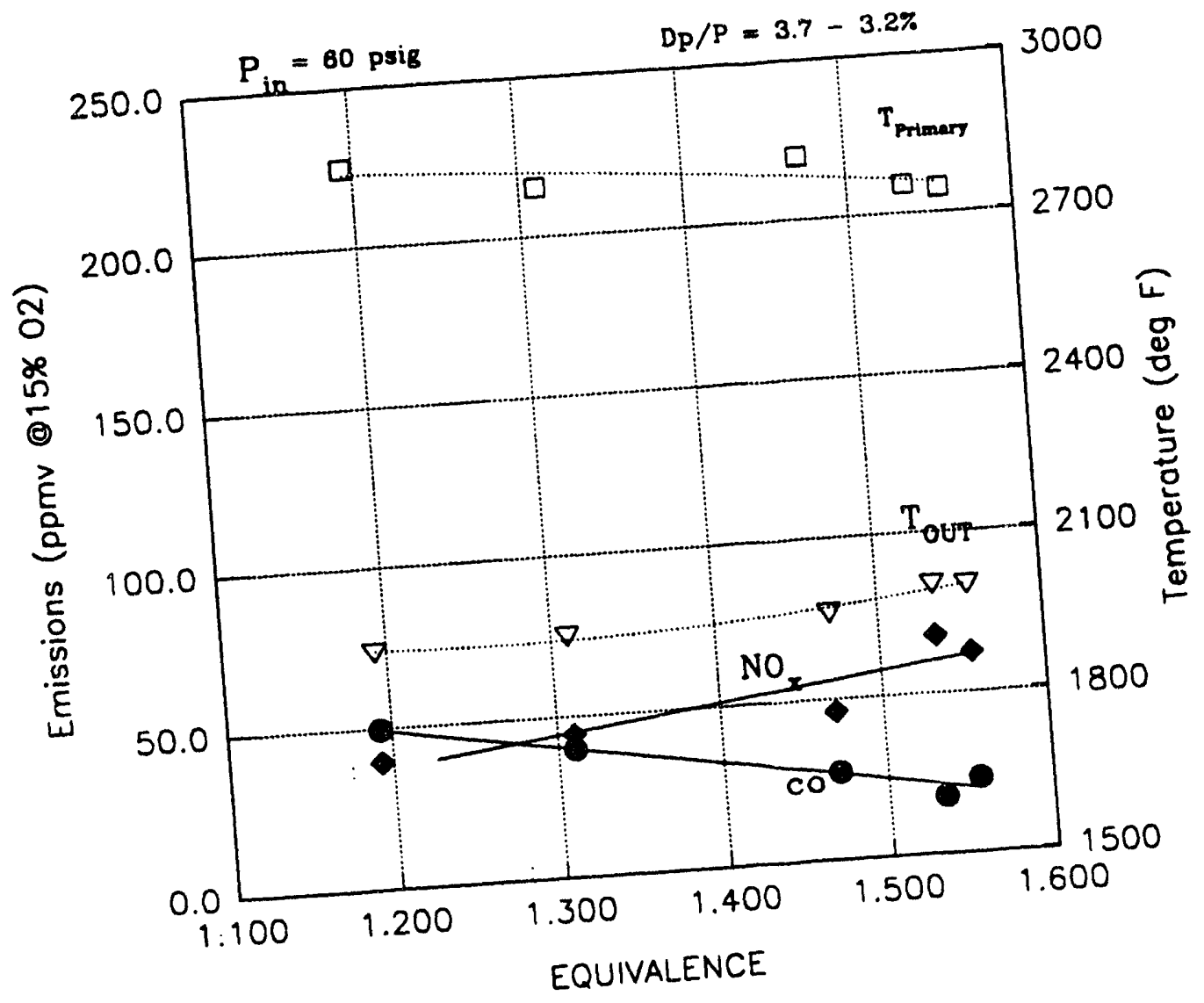

Figure 15. The Vartation of Emissions and Outlet Temperature Versus Equilvalence Ratio for Teat No. 4
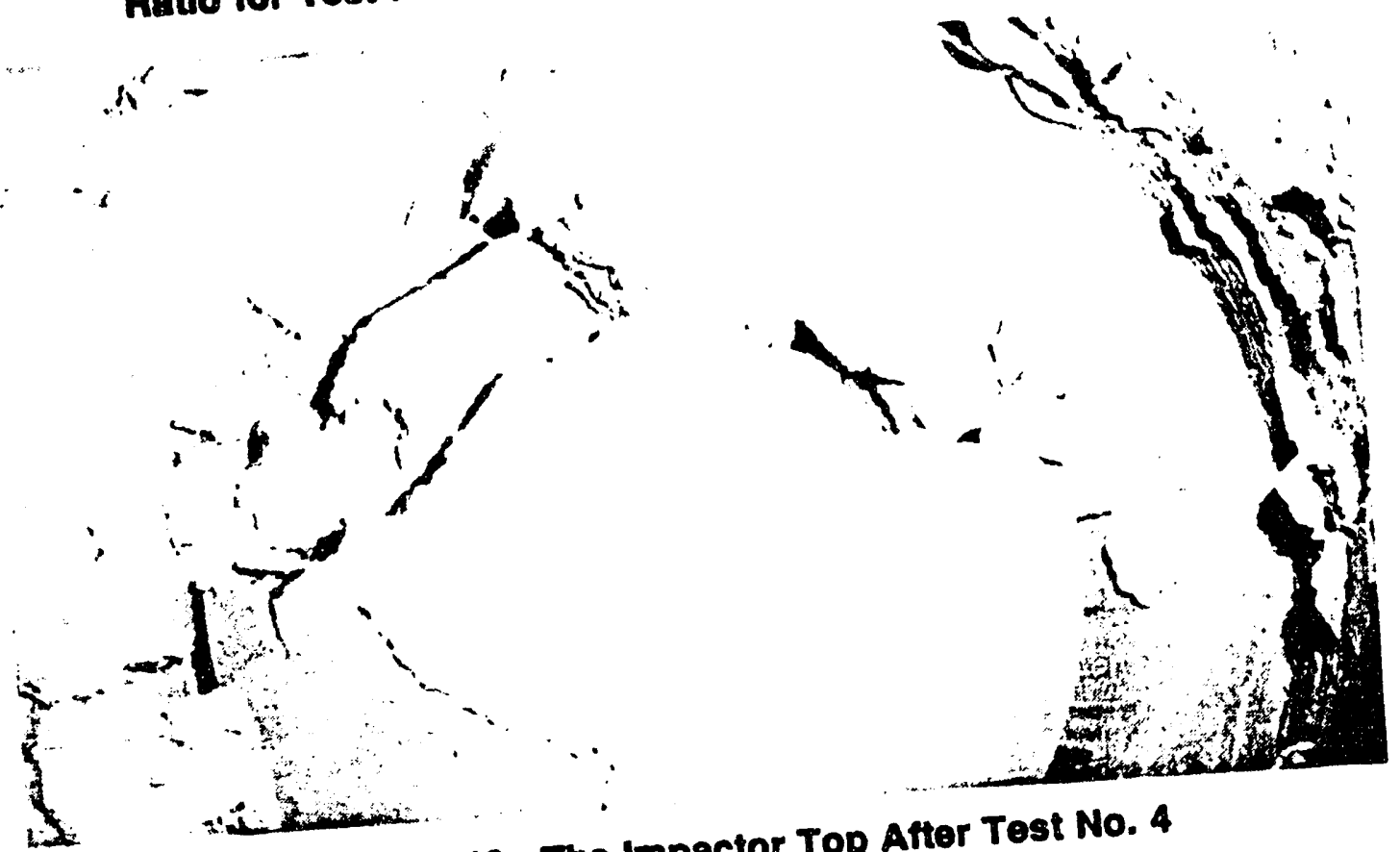

Flgure 16. The Impactor Top After Test No. 4 


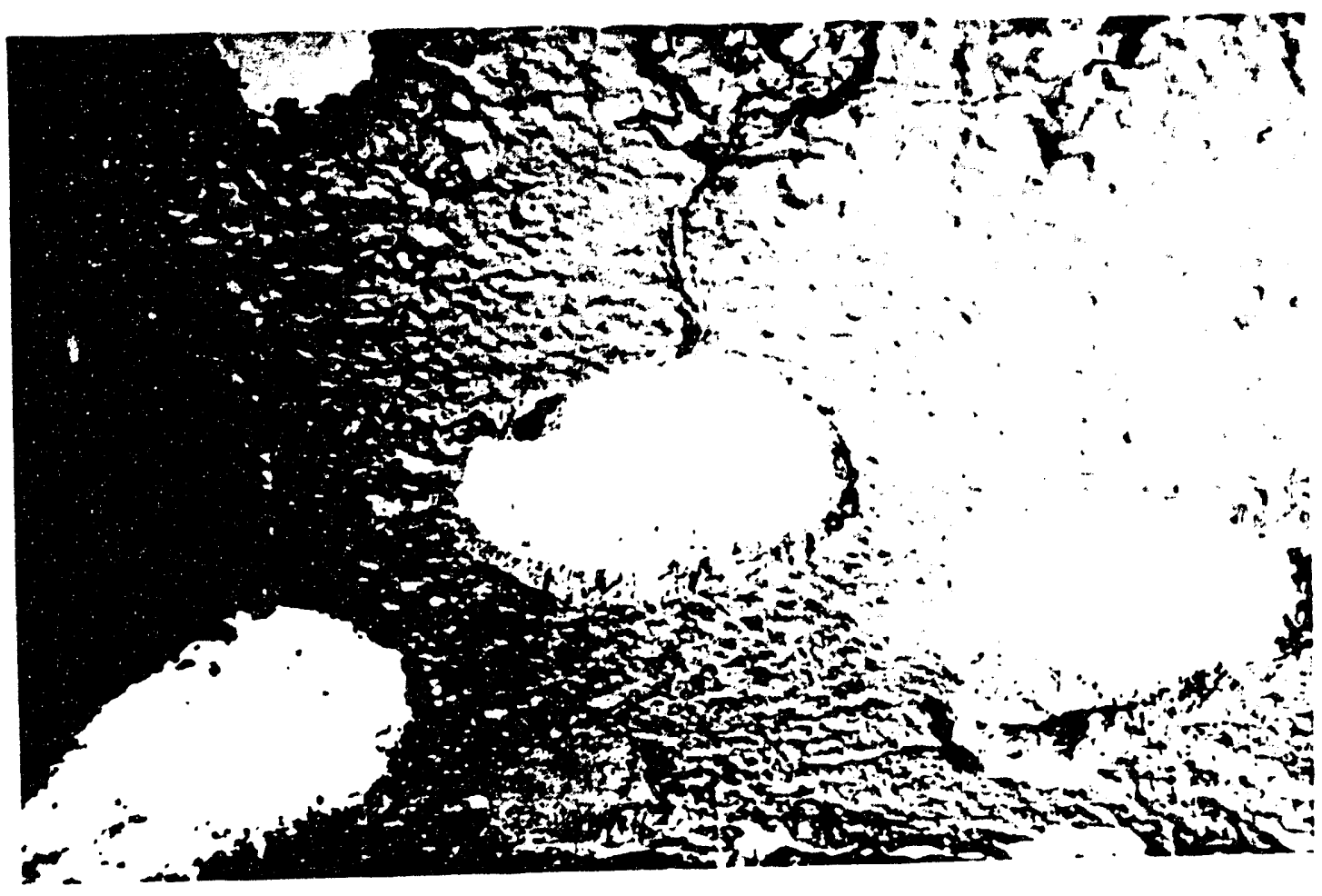

Fgure 17. Retractory Spalling on the Primary Zone Walls Following Test No. 4 

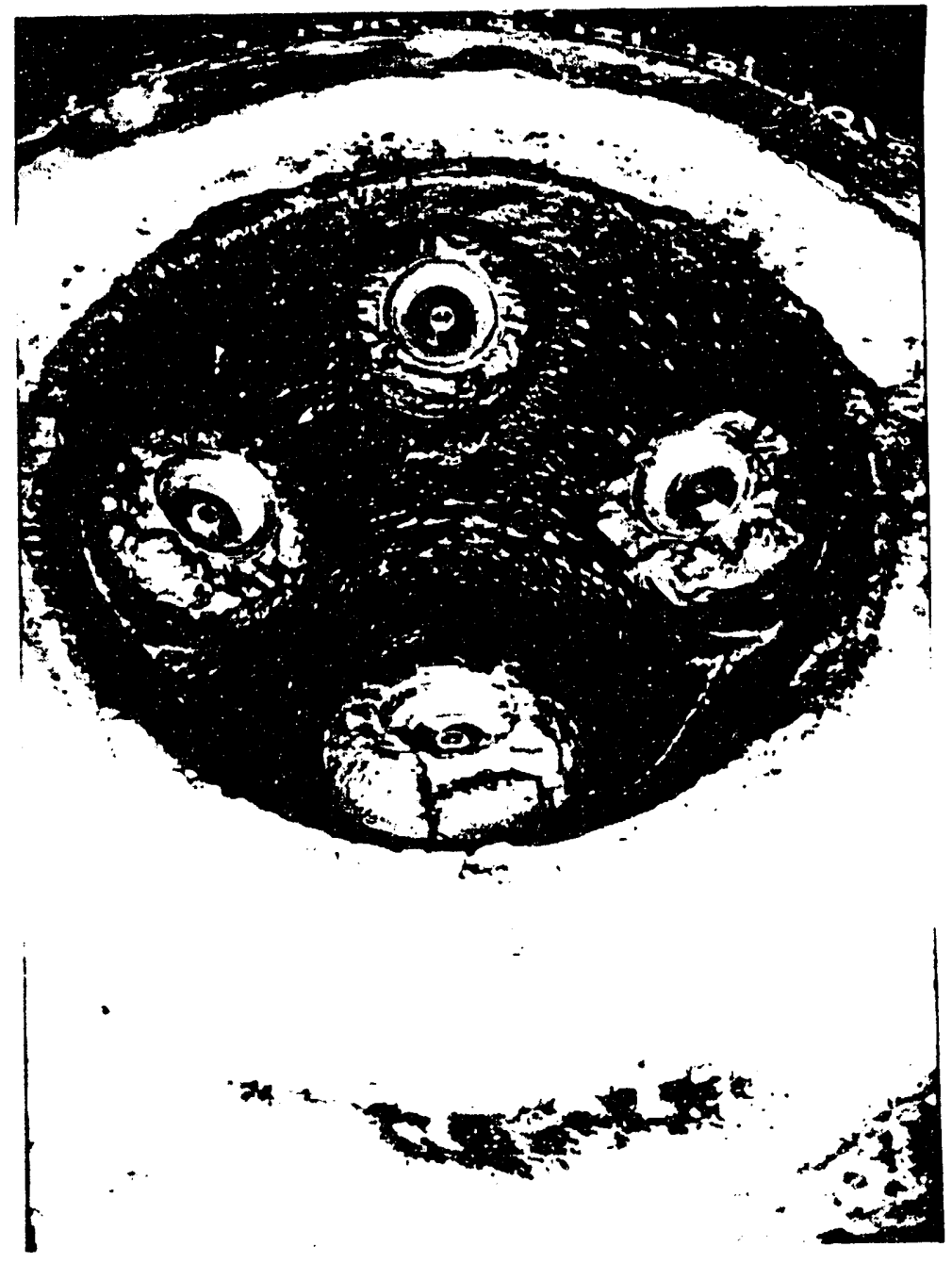

Flgure 18. The CWM Injector Following Test No. 4 


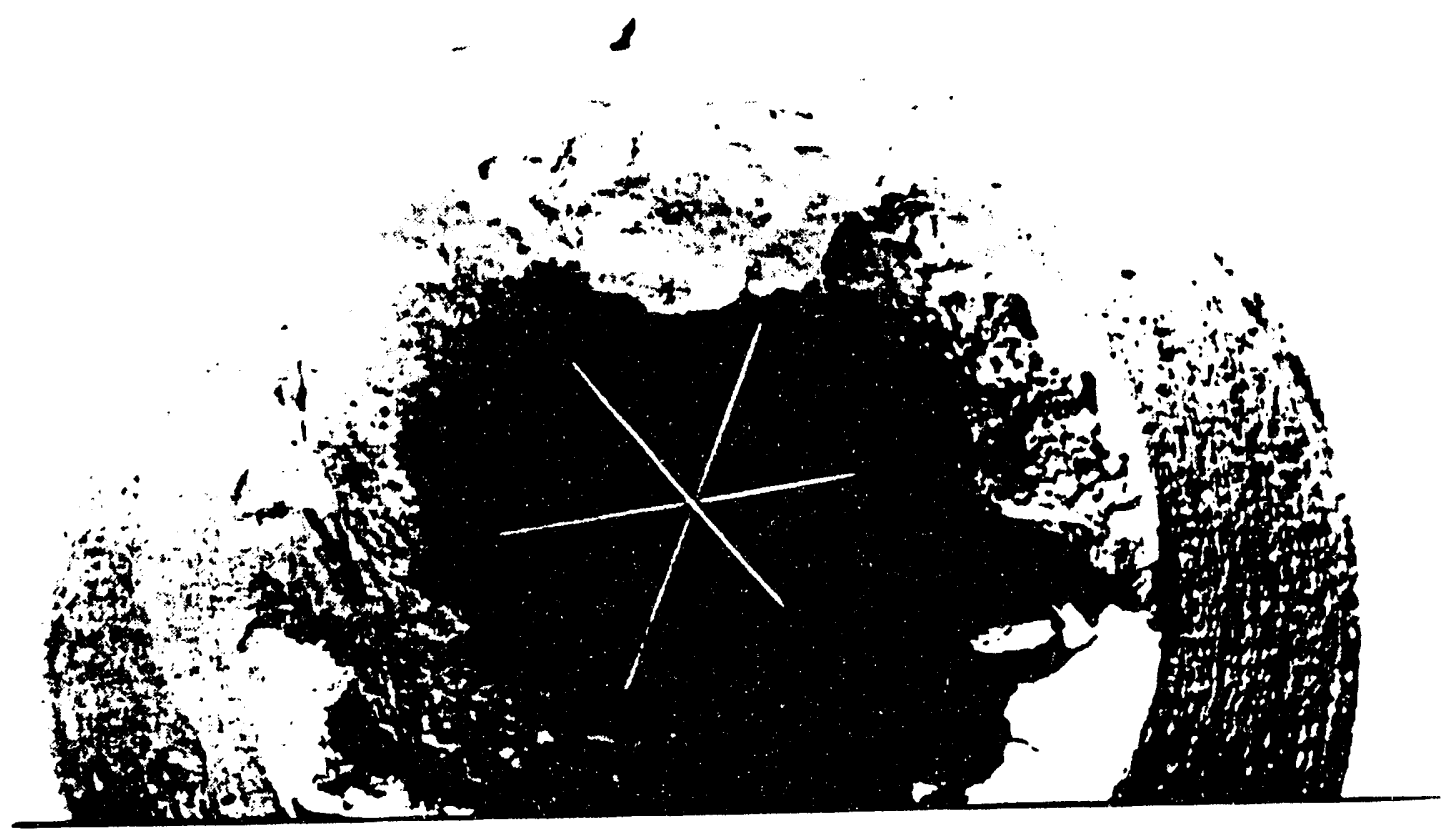

Figure 19. A Downstream View of the Secondary Combustor With Slag Accumulatlons at the Secondary Air Inlet Ports. Emision Probes are Visible Further Downstream. 


\section{PHASE II - TASK 2 - PARTCULATE REMOVAL SYSTEM DEVELOPMENT}

\subsection{SPECIFC ITEMS OF PROGRESS}

\subsubsection{Post-Primary Systom}

- Anatysis of the silicon carbide PRIS tubes exposed to CWM combustion in all tests before IBSTF No. 9 has been completed. The tubes have been degraded by resctions of Iron from the coal ash with sillca from the PRIS tubes to form an Iron slicate that is easily eroded.

- The subscale PRIS with alumina rods has been in position during all testing since IBSTF No. 9. Included is a sample section located upstream of PRIS inlet which has test pieces of alternate PRIS rod materials including Lanxide, mullite, silicon carbide, zirconia, and corderite.

- The full scale PAIS design has been completed. A full size flow visuallzation model has been operated demonstrating a low pressure loss and high slag capture. The data from the model has been used to modify the PRIS rod section and the slag tap area. Fabrication of the full size PRIS vessel has been completed for all sections except the rod spool. This section cannot be completed until the PRIS rod material is selected after evaluation of the sample pieces following the next 50 hour IBSTF test.

\subsubsection{Post-Secondary Systom}

- One of the two failed candles was examined by four point bend testing, $X$-ray diffraction, and scanning electron microscopy with EDAX.

- Resonant frequency data was collected for a new Schumacher candle as well as an exposed candle.

- Conducted frequency measurements of Schumacher candle filter in the Hot End Simulation Rig.

- A venturl scrubber system was commissioned at the IBSTF in order to meet the County of San Diego particulate requirements.

- Candles were ordered and received from Industrial Filter and Pump Manufacturing Company.

- Four filtration consultants were Interviewed and Owen Fortune was subcontracted as a filtration expert. 
- Several runs with dlesel fuel and three runs with coal were conducted on the IBSTF.

- Klstler pressure transducer measurements were taken in the IBSTF with diesel firing. Pressure fluctuations were \pm 0.1 psid in general, with occasional spikes of \pm 1 psid.

- All Industrial Filter and Pump candles have been boroscoped on the Inside. Data was reconded on video tape and aberrations noted in the reconds.

- All candles were visually inspected, weighed, and physical dimensions noted.

- Now candle mounting gaskets were manufactured.

- A test-rig apparatus was fabricated for vibration testing of the Industrial Filier and Pump candles.

- A long-term vibration test was initiated to determine the effects of local vibrations on the strength of the candles. Two new Schumacher candles have been used for this test.

- Full scale cost estimates were developed for Solar by Industrial Filter and Pump Manufacturing Comparry.

- A lean PRIS analysis was begun. Arthur Metcalfe was hired as an expert consultant.

- A two part report on the analysis of the lean PAIS was complled for Solar by Arthur Metcalfe and Associates. The first part of the report comprised the analysis of the operating conditions whereas the second part discussed factors affecting the selection of addittves. Additional work has examined removal of sticky deposits.

\subsection{DISCUSSION}

\subsubsection{Primary Cleanup Device}

\section{Subscale PRIS}

Analysis of the sillcon carbide rods removed after Test No. 9 is complete. An SEM photograph of the slag rod Interface is included in Figure 20. In the photograph the interface between the siag and the sillcon carbide has been divided into four regions (a) to (d). A piece of the rod covered with slag has been sectioned and pollshed for the SEM analyses included with the photograph in Figure 20. Region (a) is the uncorroded sillcon carbide PRIS rod. The SEM analysis indicates high levels of silica. In region (d) is the pure slag with high levels of alumina and sillca. The iron from the slag reacts with the silicon of the rods to create an iron silicate as shown in regions (b) and (c). The iron silicate created by the Interaction of the slag with the iron has a fainty low 


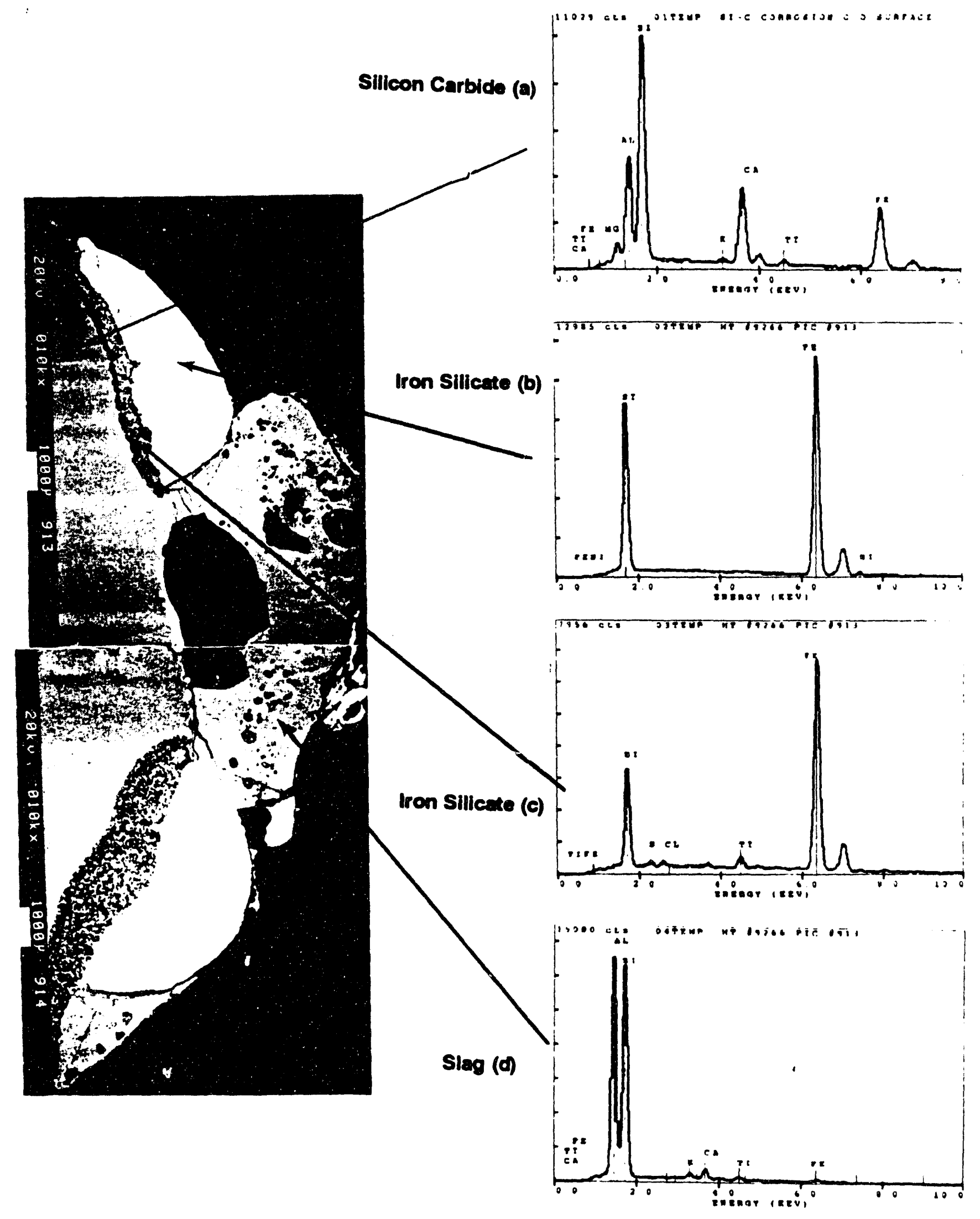

Figure 20. SEM Analysis of PRIS Rods After IBSTF Test No 9 
softening point. With the gas and particle velocities found throughout the PRIS rods the iron sillcate is rapidly eroded off the rod surface. "Fresh" silicon carbide is exposed to slag and the reaction to Iron sillcate continues as more material is lost from the rods.

The SEM analysis does not indicate a large alkall presence in any region shown in Figure 20. The lack of alkali precludes the likelihood of significant corrosion resulting from alkall attack. The presence of water vapor has been found to enhance corrosive reactions, particularty in the presence of alkall metals. The role water vapor plays in the iron-silica reactions occuming on the PRIS rods is not well defined, but should not be precluded as a possible ald in the corrosion process.

The subscale PRIS is being prepared for the next long duration IBSTF test. The PRIS has been exposed to combustion in three IBSTF tests. The rod-type insert with high purity alumina rods has been installed in the pressure vessel. The alumina rod PRIS inlet and outlet are included as photographs in Figures 21 and 22, respectivley. Sample rods of Lanxide, mullite, sillicon carbide, zirconia, and cordertte have also been installed in the cavity upstream of the insert for exposure in the next test. A photograph of the rods are included in Figure 23. These rods are cast at one end only and examined after testing for hot corrosion or erosion. The rod types and dimensions are summarized in Table 5.

These rods have been cast in a refractory base that will fit in the cavity upstream of the PRIS inlet as shown in Figure 24. The base has been before installation was completed.

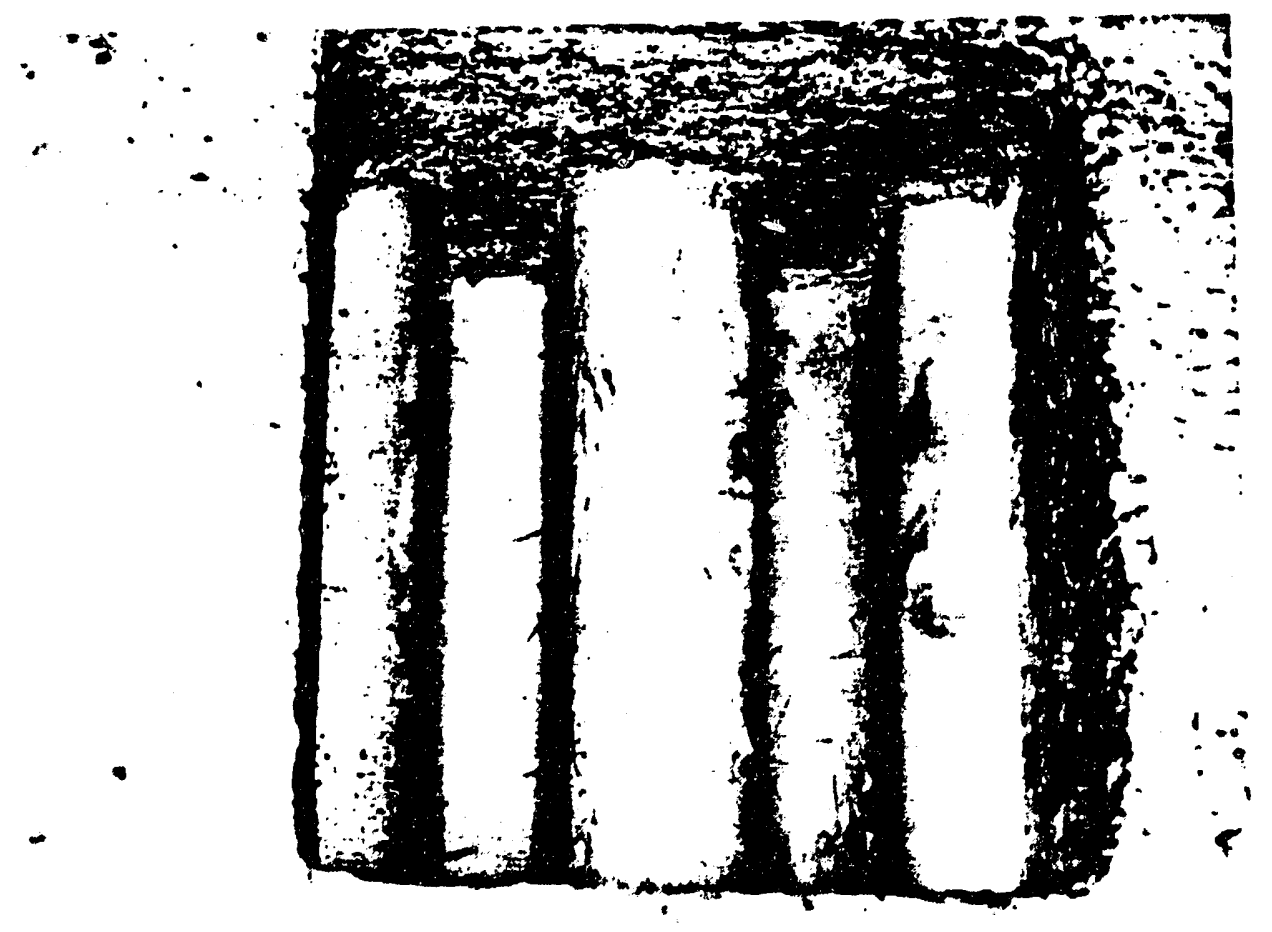

Figure 21. Alumina Rod PaIS Inlet 


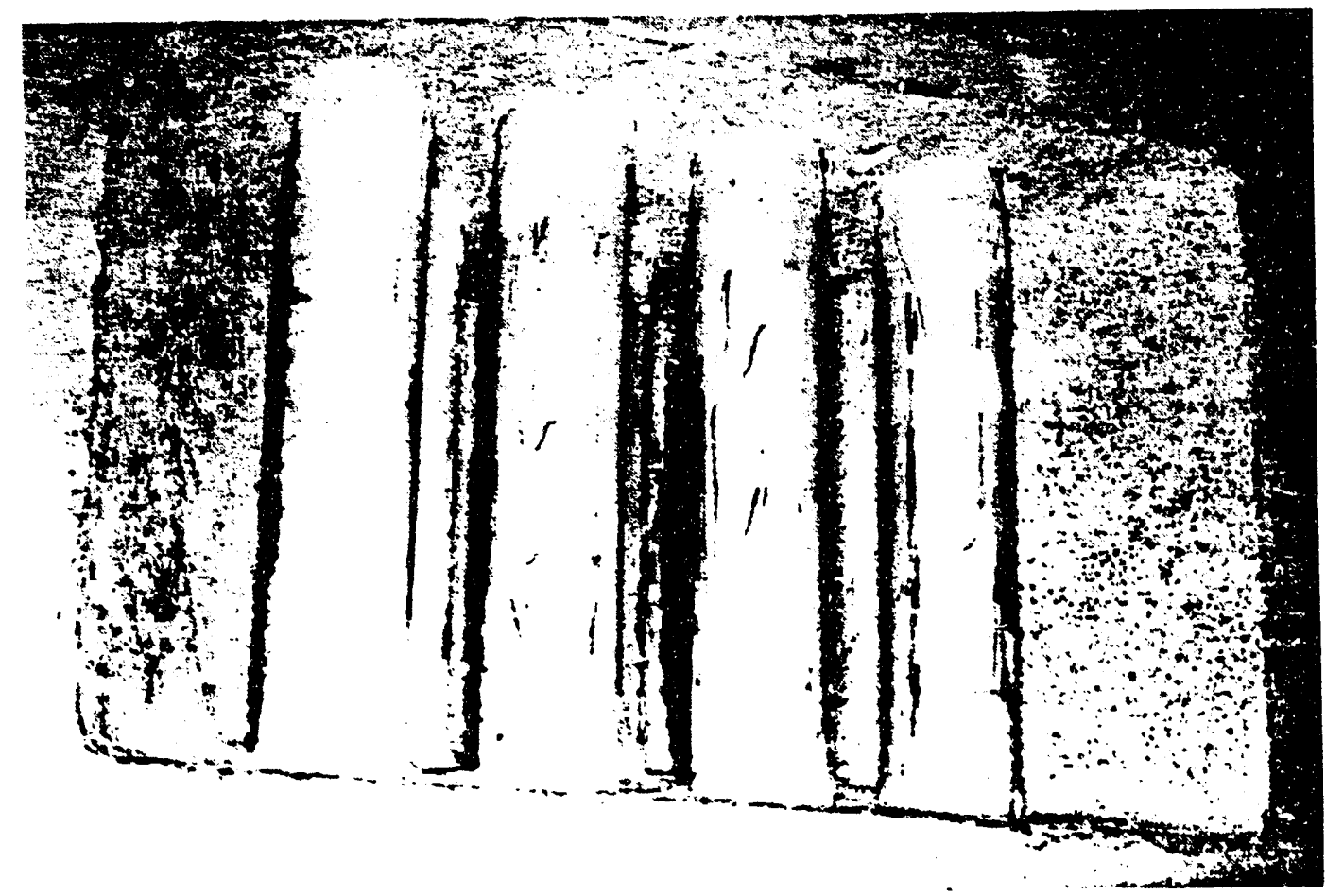

Figure 22. Alumina Rod Pris Outlet

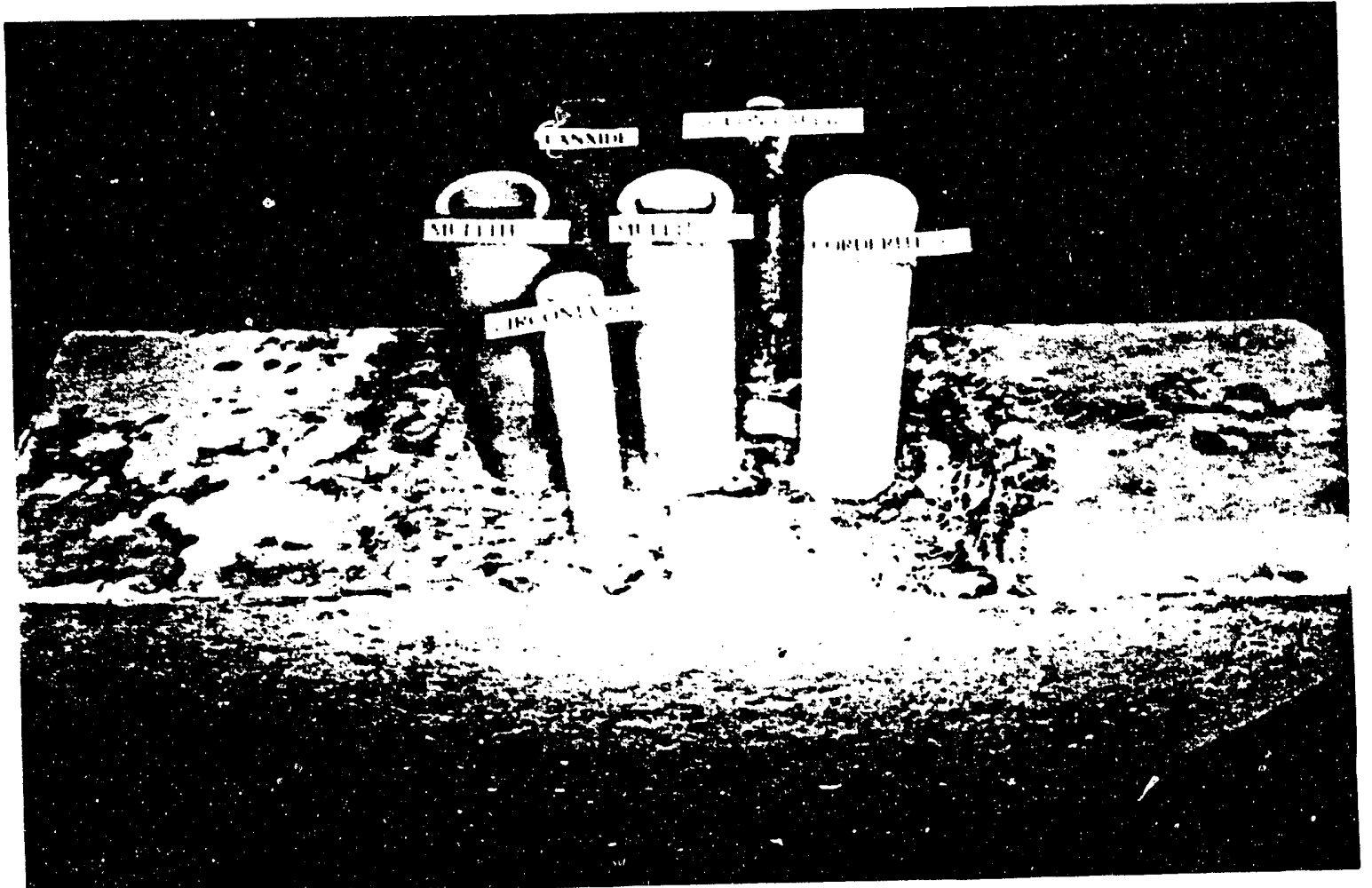

Figure 23. PAIS Subscale Rod Materlal Cast in Support for Mounting in the IBSTF 
Tablo 5. Sample PAIS Rods to be Evaluated for Hot Corroslon/Erosion In IBSTF Teat No. 10

\begin{tabular}{|c|c|c|}
\hline Material & Shape & Dimensions \\
\hline I-Z̈rconia 690 & Tube & $11 / 16$ in. $O D \times 7 / 16$ in. ID $\times 6$ in. LG \\
\hline I-Mullite 980 & Tube & 1.25 in. OD $\times 7 / 8$ in. ID $\times 6$ in. LG \\
\hline I-Mullite 900 & Tube & 1.25 in. $O D \times 3 / 4$ in. ID $\times 6$ in. LG \\
\hline 1-Corderite 995 & Tube & 1.25 in. $O D \times 3 / 4$ in. ID $\times 6$ in. LG \\
\hline Lanxide $90-x-060$ & Tube & 1.0 in. OD X 0.775 in. ID X 6 in. LG \\
\hline SIC - Hexoloy & Tube & $1.0 \mathrm{ln} . O D \times 1 / 2 \mathrm{in.}$ ID $\times 6$ in. LG \\
\hline
\end{tabular}

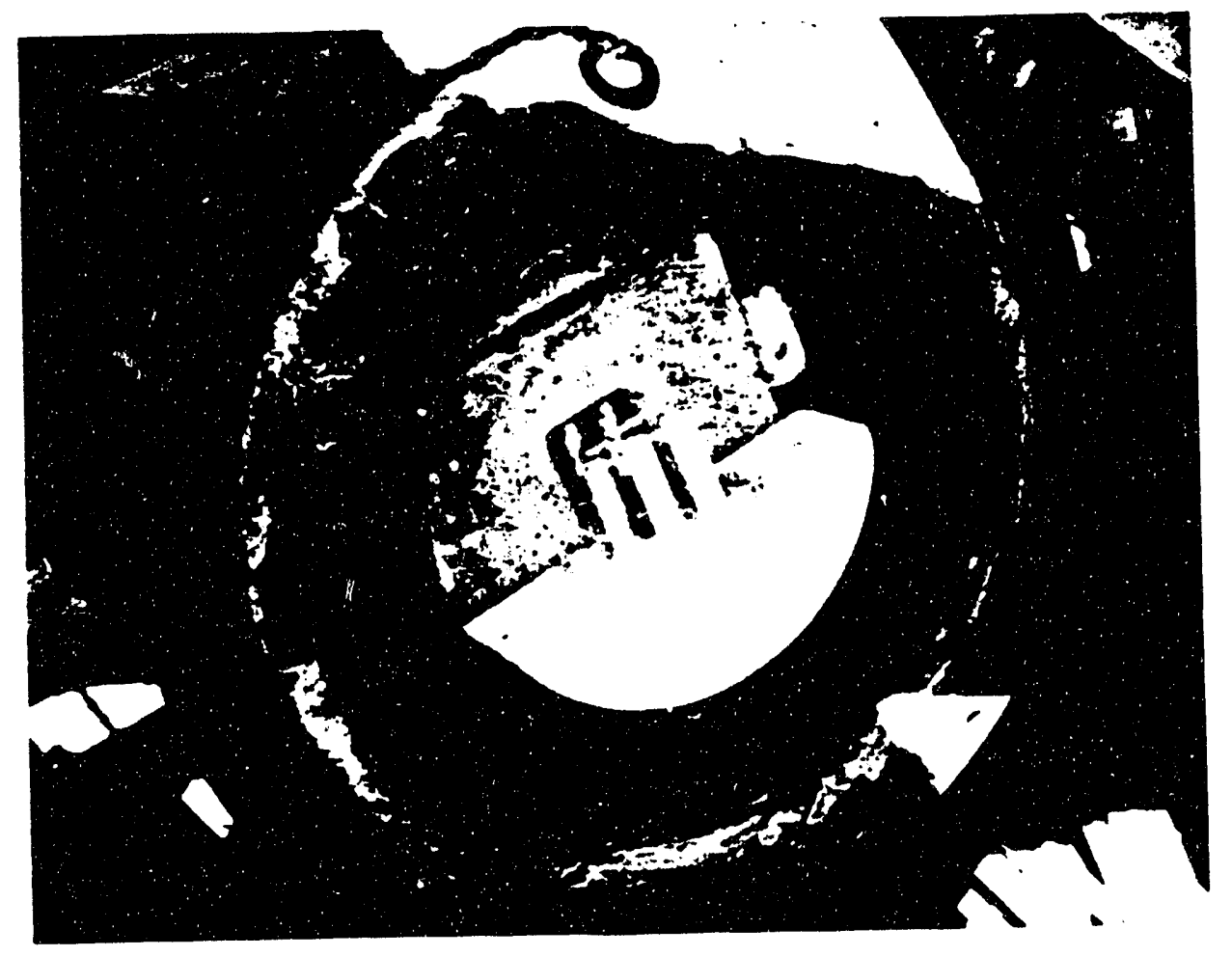

Figure 24. Sample PRIS Rods Mounted In IBSTF Upstream of Alumina Rod Insert 


\section{Full Scale PRis}

The full scale flow visualization model has been fabricated and is pictured in Figure 25. The model has been tested with hellum bubbles to trace the aerodynamic streamines. These tests have indicated that flow through the rods and the duct downstream are uniformly distributed across the radius. As the air travels downstream of the PRIS rods it maintains a uniform profile until it nears the exhaust duct where it rapidly contracts towards the exhaust. The flow around the slag tap is light.

The model has also been operated injecting honey into the inlet to simulate slag and predict slag capture and flow characteristics. The results indicate that the PRIS captures $98+\%$ of the honey. The honey flows down the rods and along the bottom of the PRIS duct in a stream. The slag tap area of the model has been modified to improve slag flow through this region.

The full scale PRIS design has been completed. The design is shown in Figure 26. The design has been modified to decrease the pressure drop across the device. Cold flow pressure drop measurements taken with the flow visualization model have been made at representative flow rates. These measirements indicate that the pressure drop across the PRIS will be approximately $1 \%$. The full scale PRIS design is based on a first row velocity of $300 \mathrm{ft} / \mathrm{sec}$. The

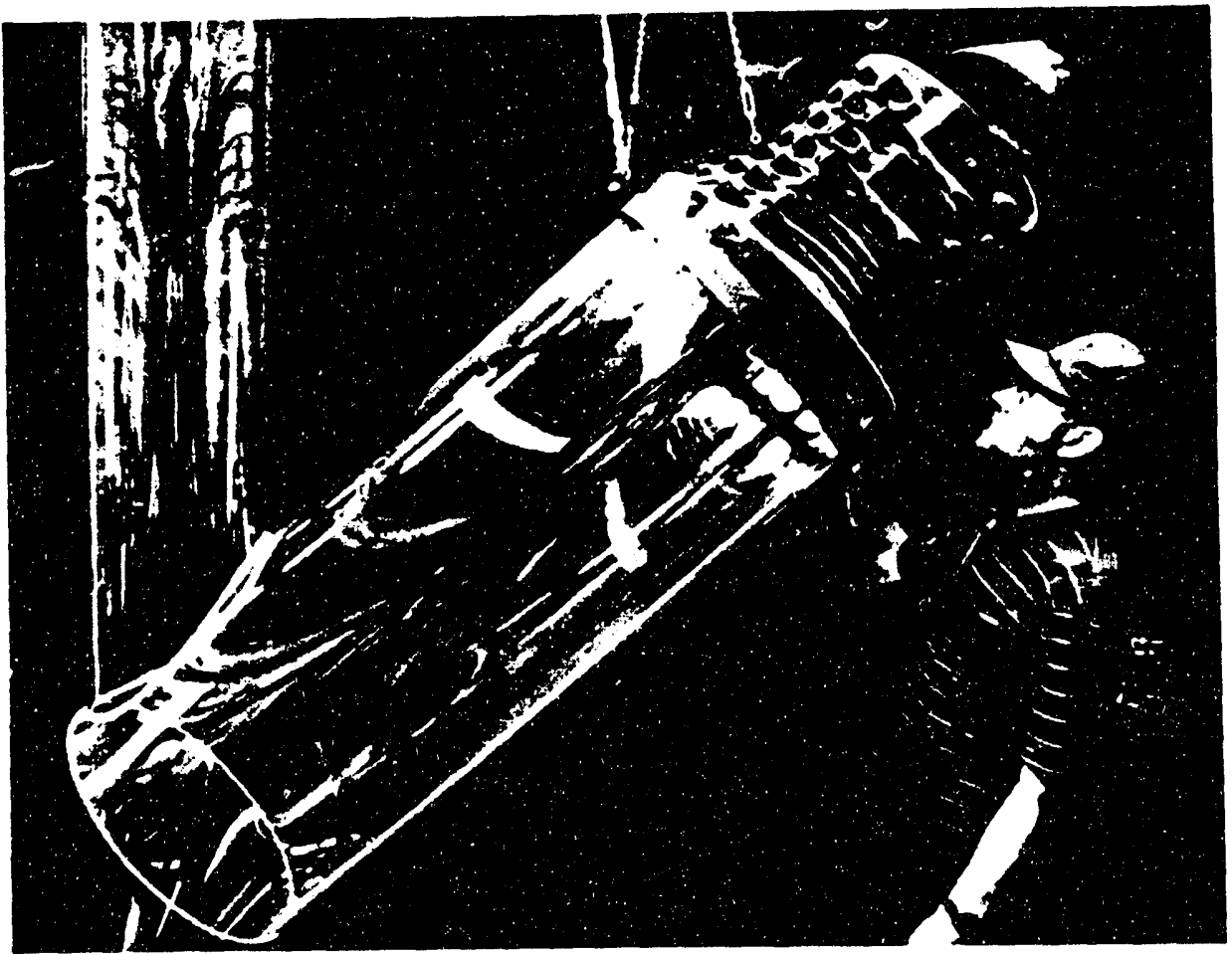

Flgure 25. Full-Scale PRIS Model 


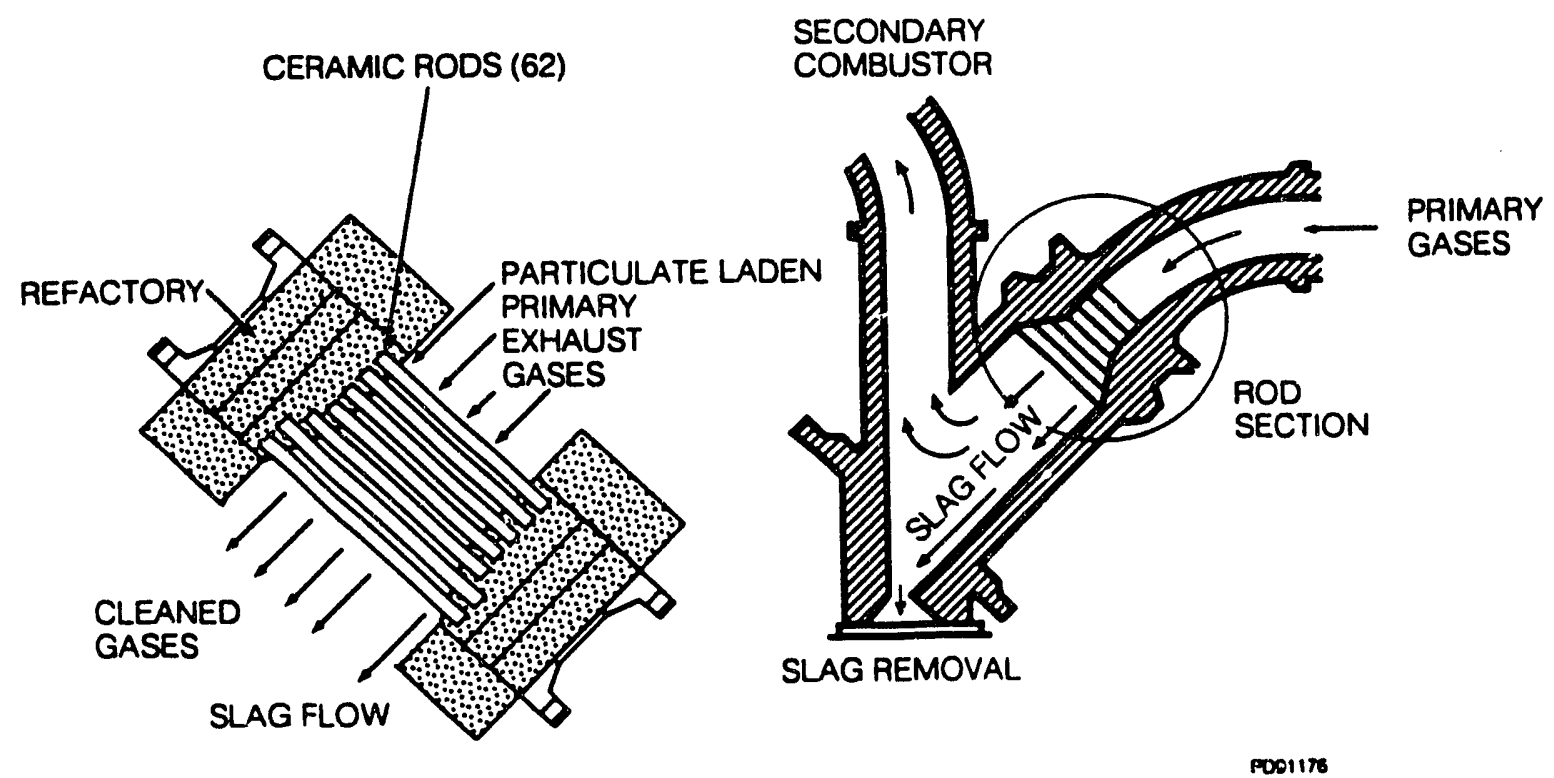

Flgure 26. The Full-Scale PRIS Design

subscale PRIS was designed with this design criterion, but actually tested at a lower velocity of $235 \mathrm{ft} / \mathrm{sec}$. In light of the high slag removal rate of the subscale PRIS, the full scale PRIS design is being modified to establish a velocity at the first row of rods of $235 \mathrm{ft} / \mathrm{sec}$. The PRIS inlet diameter is being increased from 15 to 16 inches with an additional rod being placed in each of the first four rows. The outlet diameter of the PRIS will remain at 21 inches. The pressure drop of $1 \%$ will be improved further with the modified PRIS design with the reduced velocities.

The full scale PRIS design detalls were sent to Cascade Mechanical in Spring Valley, CA and fabrication of all vessel components have been complete with the exception of the final casting in the rod spool. This casting will not be completed until the material selection for the rods is made. This selection will be based largely on the results of the next IBSTF duration test. Photographs of the PRIS vessels are included in Figures 27 and 28.

\subsubsection{Post-Secondary Systems}

\section{Testing}

A fifty hour test was conducted in 1990 in which two candle filters failed during operation. An fallure analysis was conducted and is reported here. The background of the test follows.

The two failed candles were not adjacent. Thus, one candle did not, upon fallure, strike another candle, causing it to fall. A dlagram of the proximity of the two failed candles to the Inlet gas is shown in Figure 29. One of the candles was on the perimeter nearest the inlet; the other was diametrically opposite and also on the perimeter. It should be noted that $71 \%$ of the candles were 


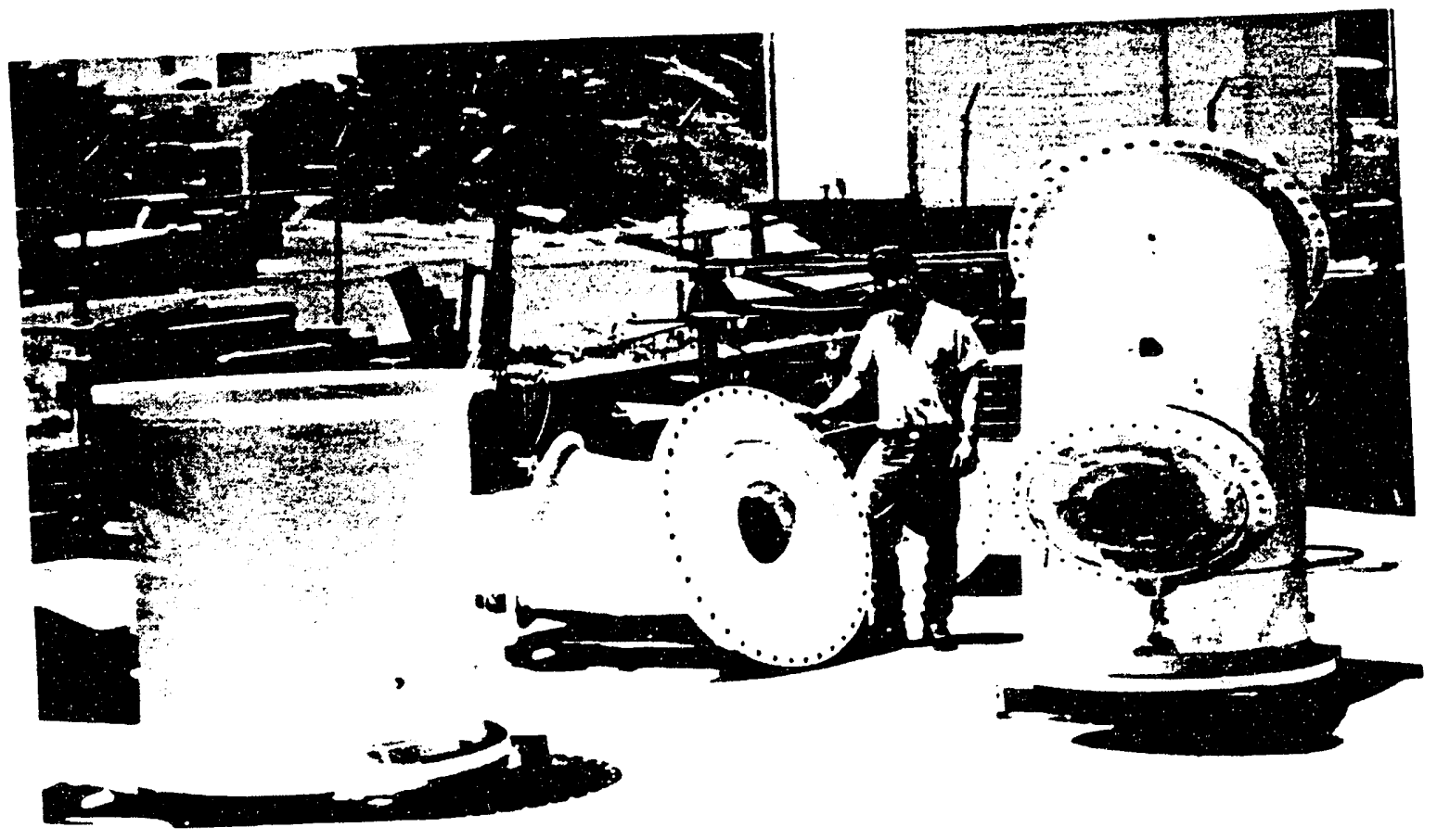

Flgure 27. Fult-Size PRIS Components Unassembled

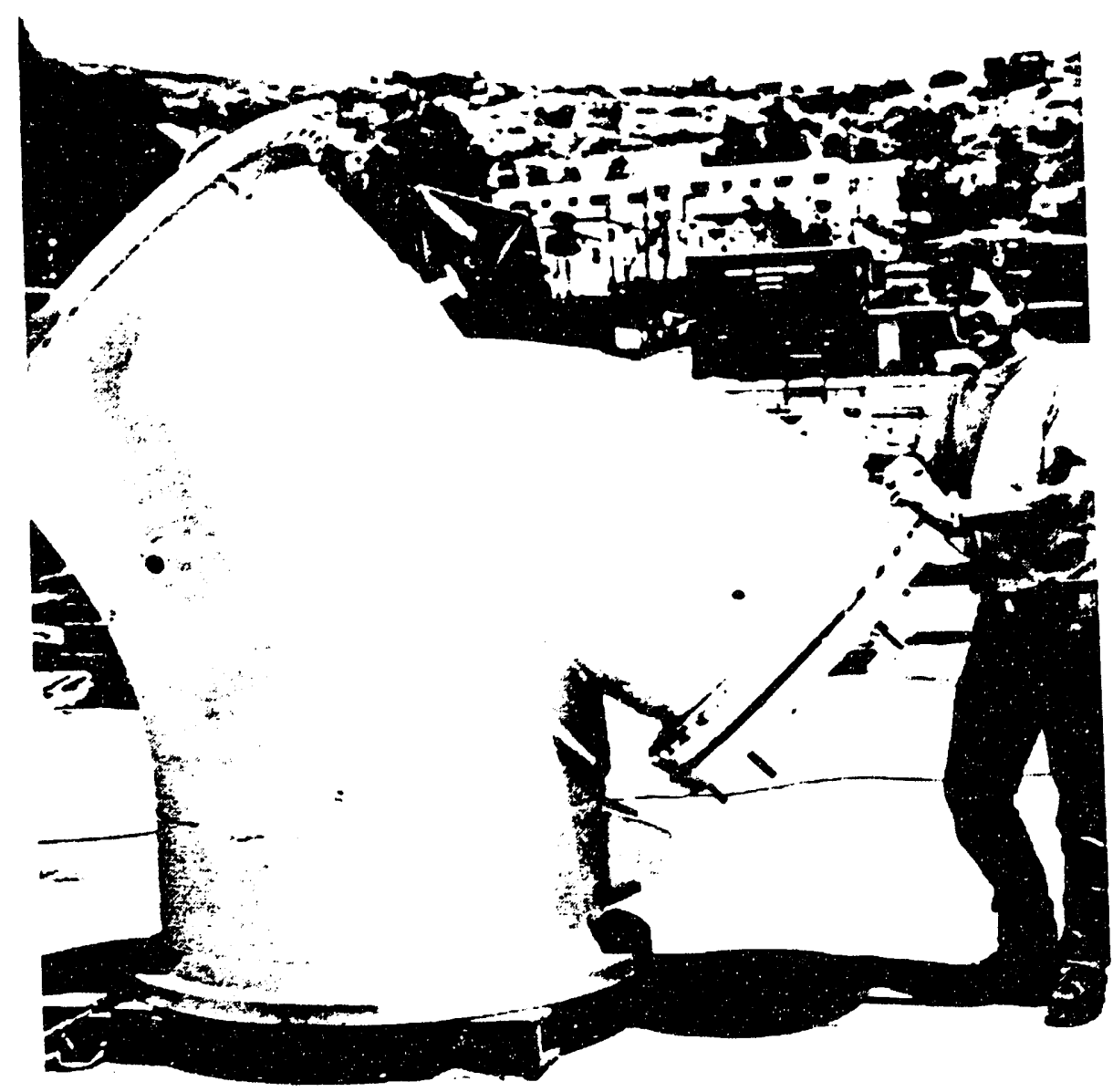

Flgure 28. Full-Slze PRIS Slag Removal Section 


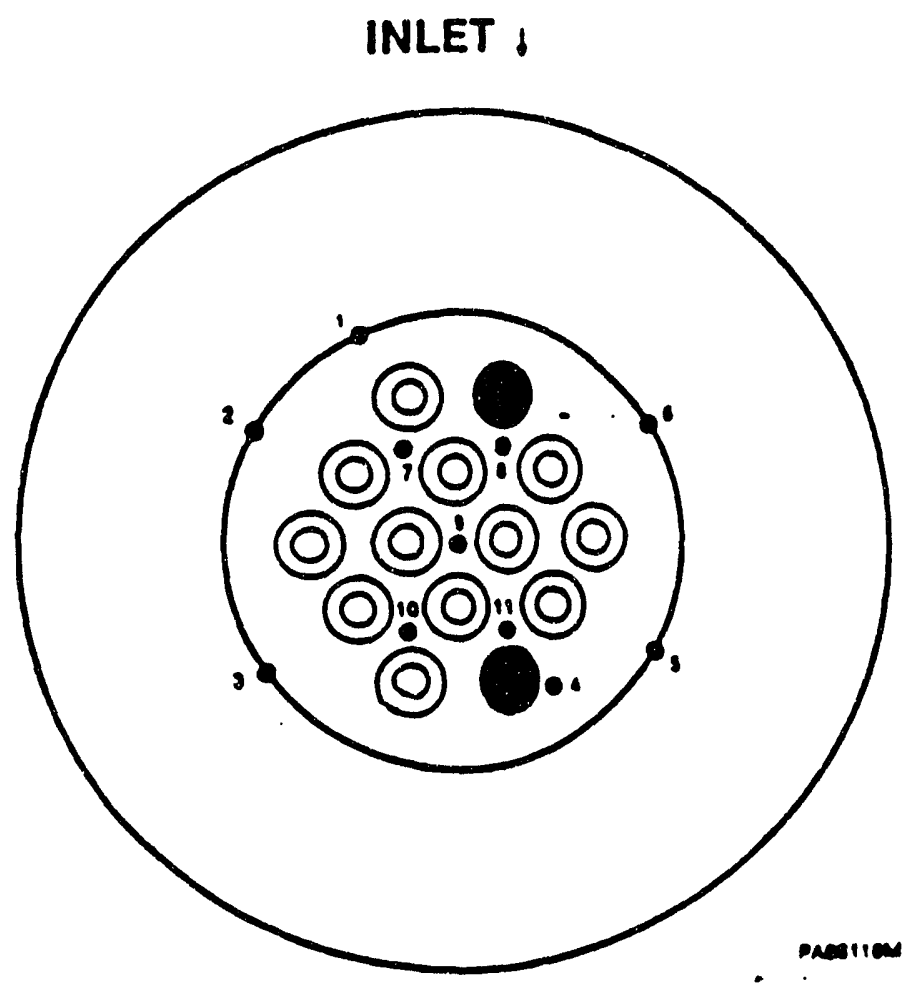

Figure 29. Location of Candle Fallures During Extended Tests

mounted on the perimeter. Thus, the probability that if two candles falled happened to be on the perimeter is 49.5 percent, assuming location had no effect.

It is noteworthy that both failures occurred about within seven inches of the top flange. A summary of the location on the candle where breakages have been observed is noted in Table 6.

\section{Analysis of Falled Candles}

An analysis of falled candles was initiated to determine what causes were responsible for the breakages. This analysis included drawing up a fault tree for the analysis, analysis of one of the broken candles, and also, examining the various possible causes. The analysis of one of the two failed candles was undertaken by Acurex Corporation. Additional testing of exposed candles is planned under a future subcontract with Acurex.

The fautt tree analysis is shown in Figure 30.

Acurex Corporation examined one of the two falled candles from the extended test. Earller, Acurex examined three virgin candles from the same batch. The approach Included visual examination, scanning electron microscopy with Energy Dispersive Spectroscopy (SEMEDX), $X$ Ray Diffraction (XRD) and four-point bend testing. Examination of unused filters provided baseline data for comparison. 
Table 6. Summary of Location of Candle Breakages

\begin{tabular}{||lll||}
\hline \multicolumn{1}{|c|}{ Date } & $\begin{array}{c}\text { Location } \\
\text { (Inches from top flange) }\end{array}$ & \multicolumn{1}{c|}{ Occurrence } \\
\hline 18 Aprll 90 & 5.5 & Earthquake \\
18 April 90 & 5.6 & Earthquake \\
\hline 10 May 90 & 7.0 & Extended test \\
10 May 90 & 7.0 & Extended test \\
\hline April '90 & 5.25 & Handling \\
May '90 & 6.75 & During removal \\
\hline KRW Gasifier & & (mechanically casued \\
& & failures) \\
& 6.5 & \\
& 5.375 & \\
& 5.0 & \\
& 5.5 & \\
& 5.75 & \\
& 9.25 & \\
& 8.25 & \\
\hline
\end{tabular}

The candle that was received by Acurex was in several pieces, although essentially all the pieces were recovered so that it was possible to reconstruct it. Both sides of the cracked surface were examined. Examination of the top part of the candle revealed two holes, shown here in Figures 31 and 32. One hole was quite large (approximately $3 \mathrm{~mm}$ ) and extended from the inside surface approximately $10 \mathrm{~mm}$ towards the outside surface. The second hole was much smaller and irregularly shaped, but extended completely through the candle. The crack ran throunh both of these holes. The smaller hole also showed evidence of dust penetration, indicating that there was flow through this hole before the candle broke.

Four-point bend data were obtained for the failed candle as well as three unused specimens. There was a significant decrease in strength. The degradation was so pronounced that after cutting bars for the bend test, the material appeared to be very weak and crumbly to the touch. In fact, the first set of bars failed prematurely; therefore, a different technique was used for surface preparation. The second set of bars had a finish ground to one micron. These specimens produced more consistent results. Test results for the unused and exposed samples are shown in Table 7 and Figure 33. 


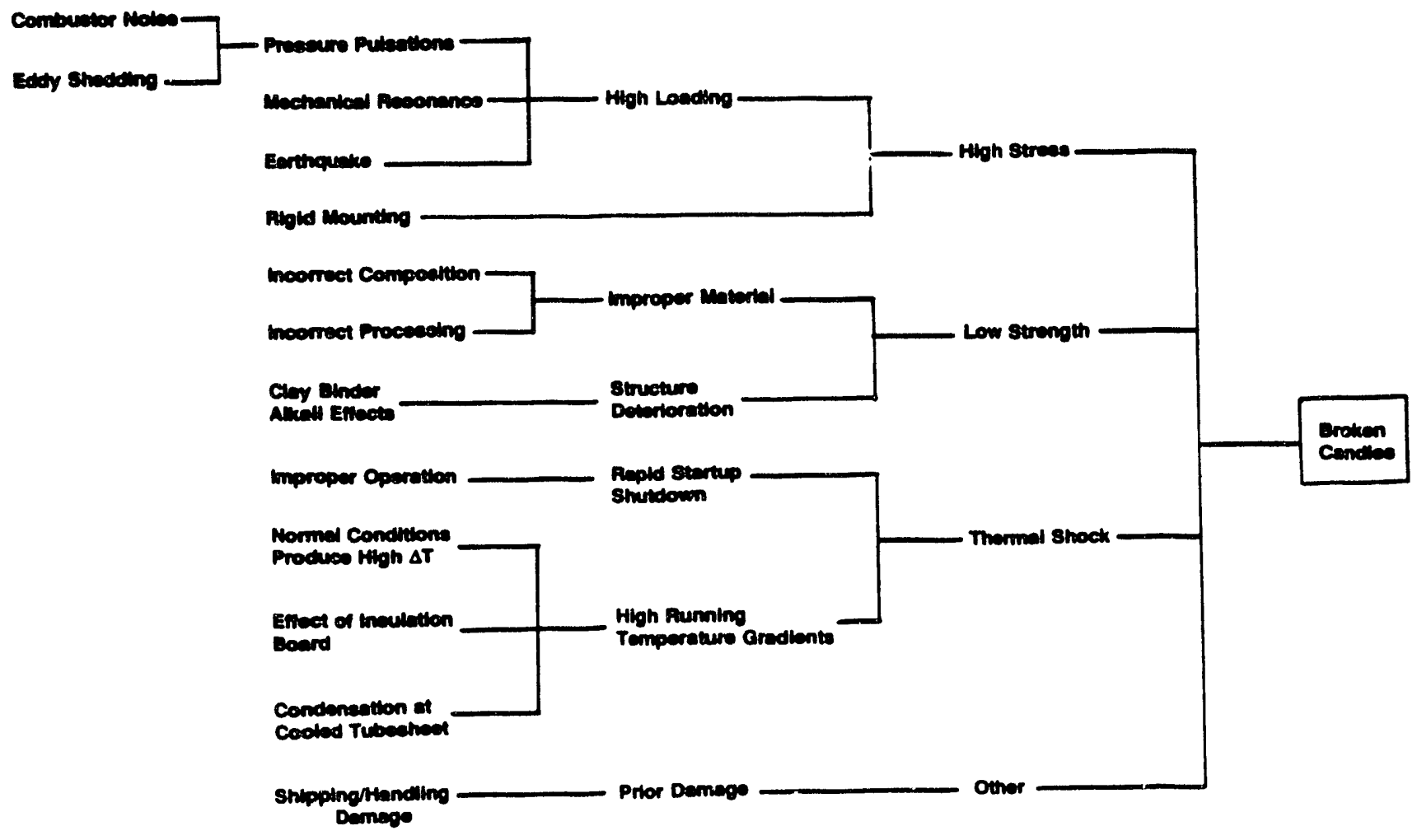

Figure 30. Candle Fallure Analysle Tree

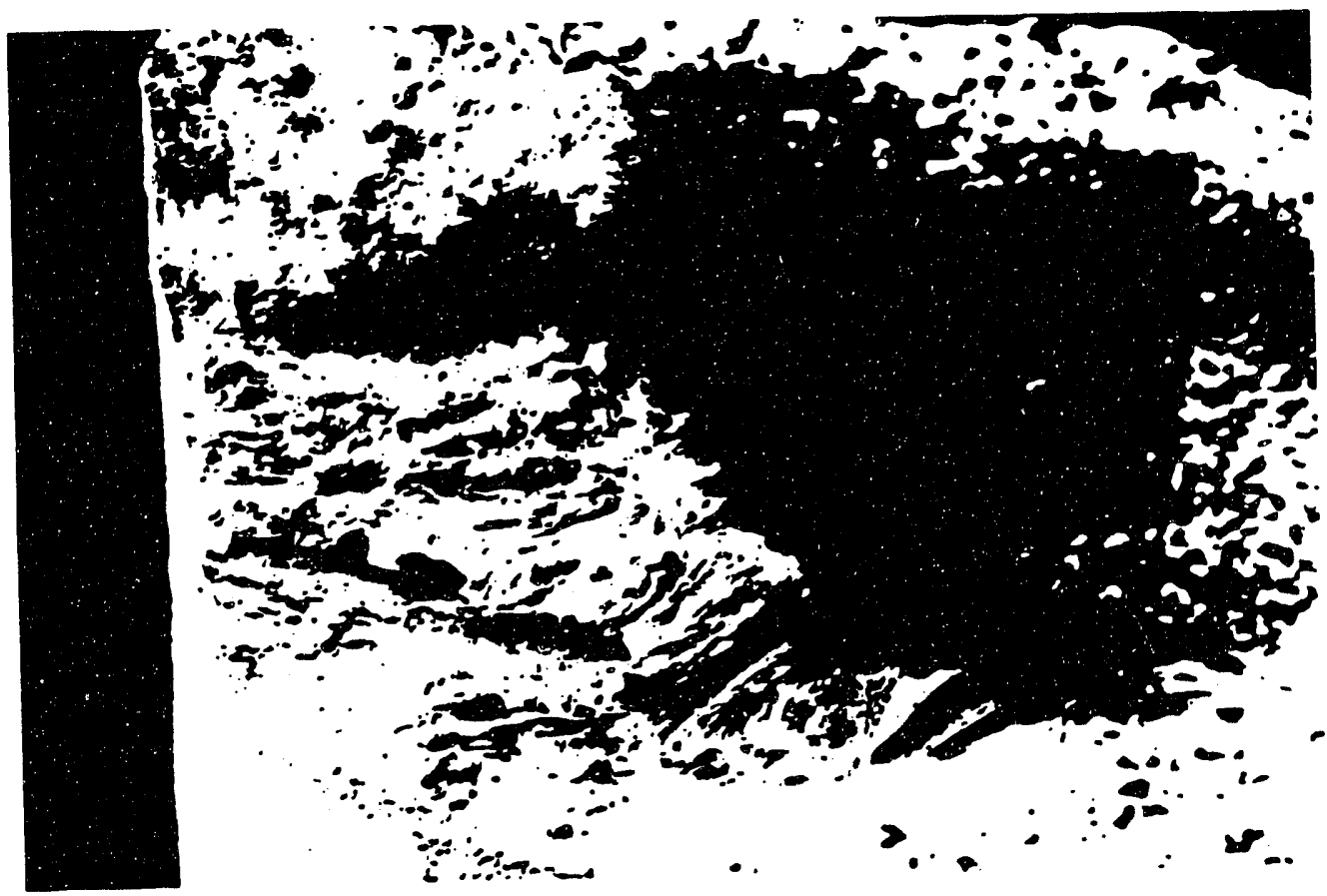

Figure 31. Imperfectlons in Candle Wall 


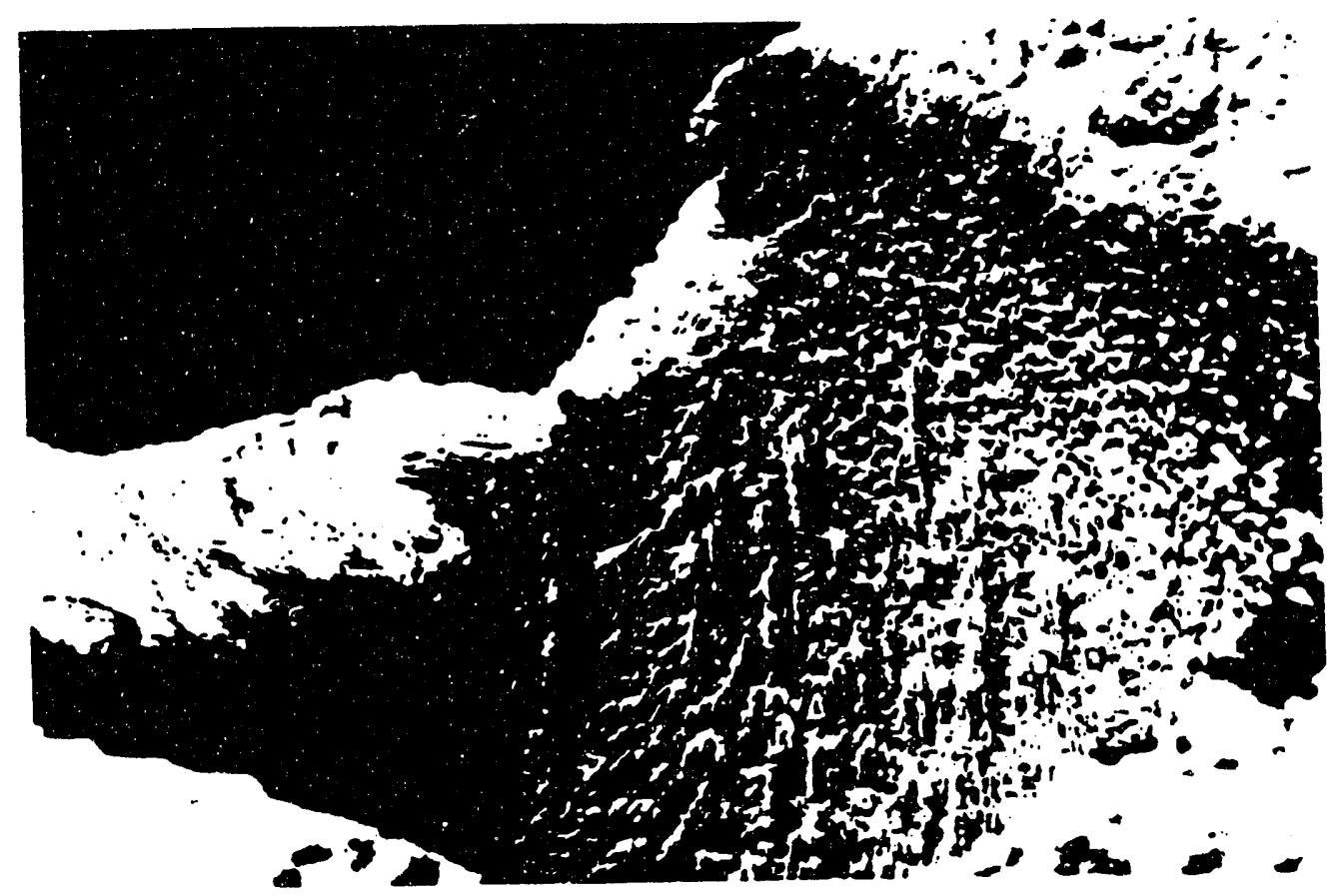

Figure 32. Hole Through Candle Wall (from Interlor of candle)

Table 7. Four-polnt Bend Test Data for Candle Specimens

\begin{tabular}{||lll||}
\hline Sample & MPa Mean & Std. Dev. \\
\hline Unused \#1 & 12.0 & 0.987 \\
Unused \#2 & 14.1 & 1.107 \\
Unused \#3 & 13.6 & 0.575 \\
Exposed & 5.1 & 0.626 \\
\hline
\end{tabular}

Note that for the unexposed samples, eight bars were tested for each sample, whereas only six bars per sample were tested for the exposed sample. The resulting decrease in strength for the exposed samples is more than 61 percent.

The EDX scans, likewise, were performed on exposed and unexposed samples. The results are shown in Table 8.

As can be seen, there was a substantial increase in calcium content in the exposed sample. These calcium concentrations are quite large and may, because of reactions with silica, be a cause for the strength degradation. High alkall levels over longer periods of time may cause chemical reactions to occur between the aluminum-silicon carbide binder and the potassium. This in turn could change the coefficient of thermal expansion and the thermal conductivity of the 


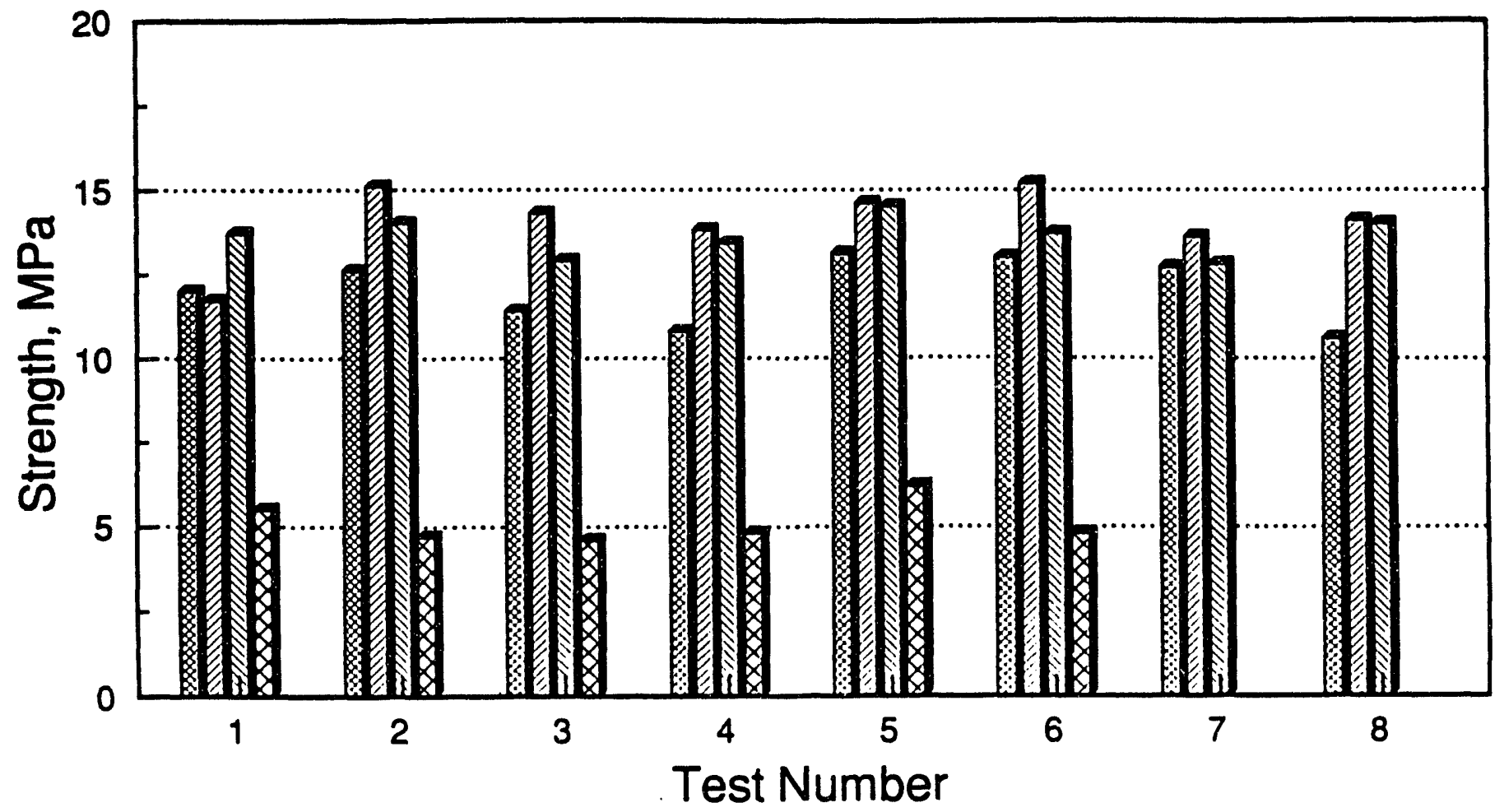

Unexposed \#1 Unexposed \#2 Unexposed \#3 Exposed

Figure 33. Four-Polnt Bend Testing

Table 8. EDX Test Data for Candle Specimens

\begin{tabular}{|c|c|c|c|c|c|}
\hline \multirow[b]{3}{*}{ Element } & \multicolumn{5}{|c|}{ Welght Porcent } \\
\hline & \multicolumn{3}{|c|}{ Unexposed Specimens } & \multicolumn{2}{|c|}{ Exposed Specimens } \\
\hline & Sample 1 & Sample 2 & Sample 3 & Sample 1 & Sample 2 \\
\hline $\mathbf{C a}$ & 0.21 & 0.228 & 0.310 & 42.27 & 53.48 \\
\hline A) & 9.98 & 10.05 & 10.07 & 2.53 & 1.68 \\
\hline $\mathrm{Na}$ & 1.06 & 0.955 & 1.285 & - & - \\
\hline $\mathrm{K}$ & 1.91 & 1.93 & 1.989 & - & - \\
\hline SI & 85.17 & 85.34 & 84.68 & 12.72 & 1.75 \\
\hline
\end{tabular}


material. The change in thermal properties could cause cracking from thermal stresses due to pulse cleaning.

The SEM photographs taken of the exposed samples are shown in Figures 34 and 35 . Photo \#1 was taken at 750 magnification and corresponds to the EDX scan \#1. As can be seen, some fusion of grains is evident from the photo. The second photo was taken at 3000 magnification, shows areas of what appears to be alkall fusion on the surface. Because the EDX analysis indicates a high lovel of calcium, this material is probably calcium sulfate (CasO, $)$.

The 3000 power SEM photo shows evidence of microcracking. The photo shows a silicon carbide grain with cracks running through the grain. This microcracking significantly affects the material strength.

The XRD analysis revealed the following phases of sillcon carbide were present: SIC: 22-1317; SIC 12H (moissonite - 6H): 29-1131; SIC 29-1128; alpha-SIC 22-1273; (SIC) 8F: 29-1129; (SIC) 33R: 22-1316; Beta-SIC: 1-1119. The plots for the three unexposed samples are shown in Figures 36 to 38 and the plot for the exposed sample is shown in Figure 39 . There were no major differences in the XRD scans.

As a result of the Acurex analysis, it was concluded that the holes in the candle wall for this particular falled candle were the cause of failure. At this point, it is not known whether the holes occurred during testing or whether they were inherent defects. There were significant changes in strength due to exposure. The candle strength decreased approximately 60 percent from the as-received condition, most probable due to microcracking of the candle structure. The cause of the microcracking is not known at this time. In addition, since the parts of the candle that were examined came from the parts that had fallen to the bottom of the vessel, impact might have caused or contribited to the cracking.

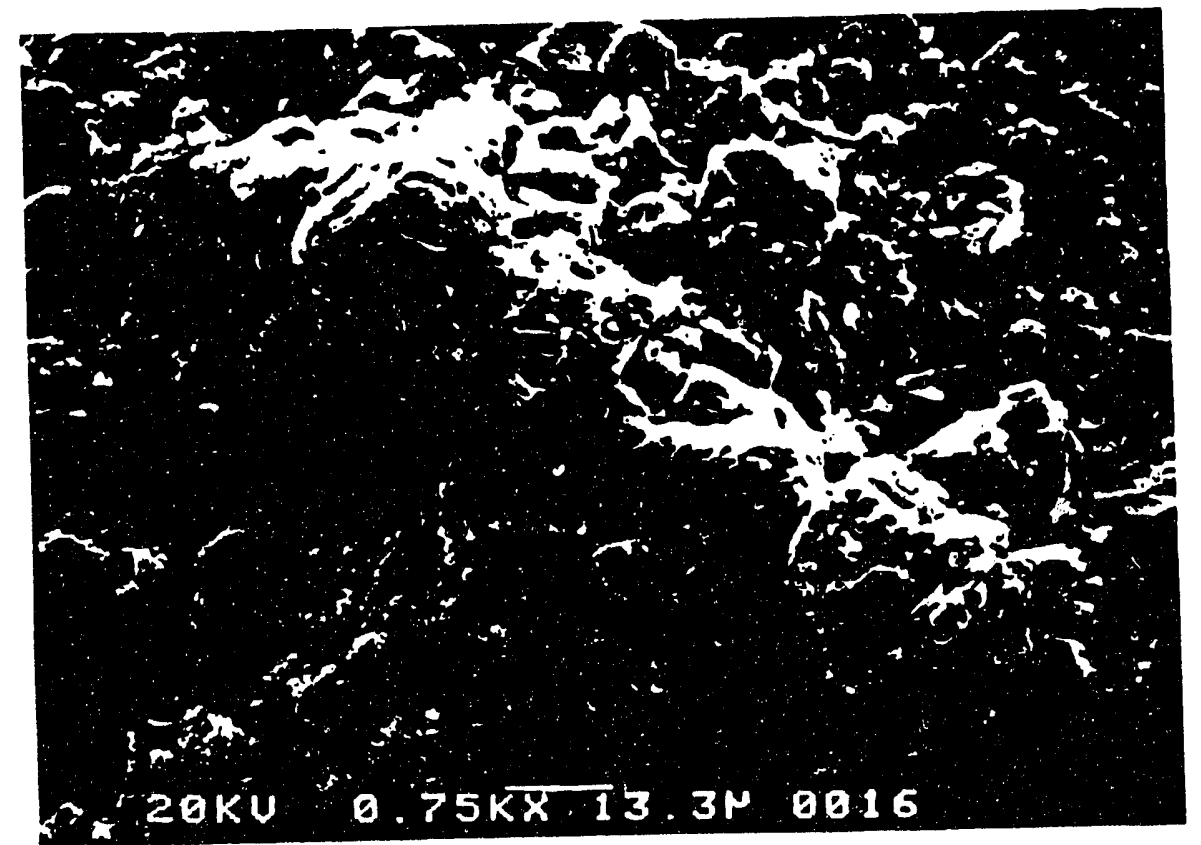

Flgure 34. SEM Photograph of Exposed Candle 


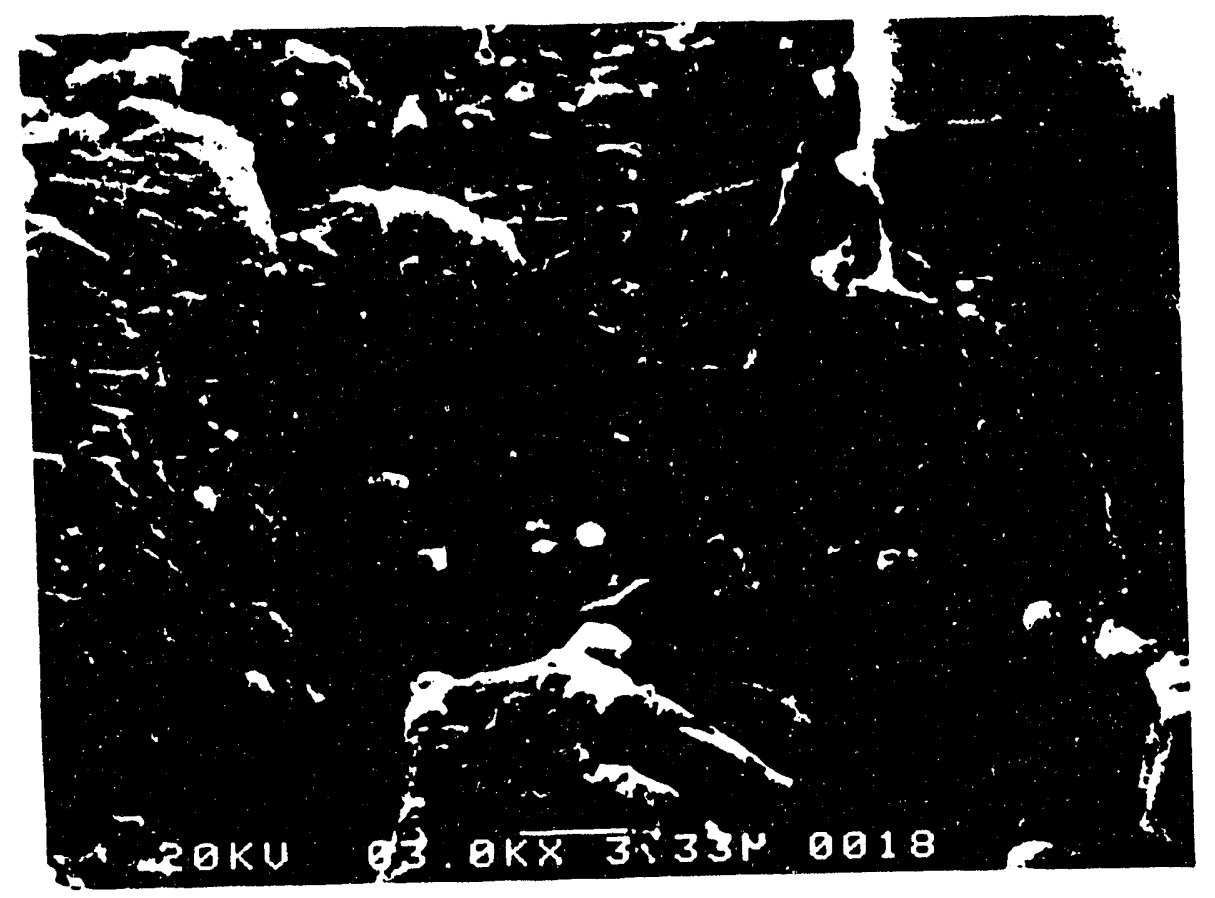

Flgure 35. SEM Photograph of Exposed Candle

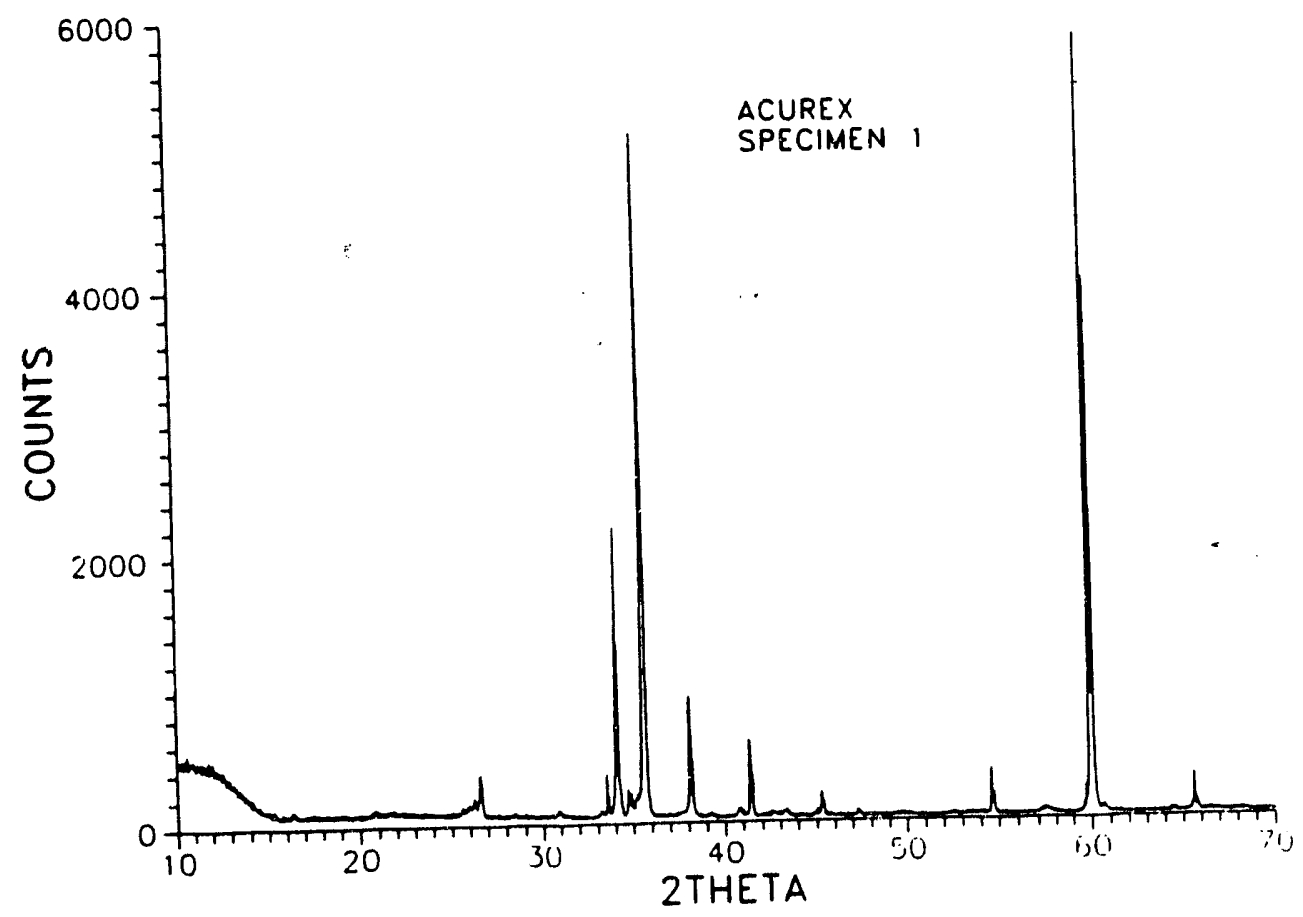

3 Flgure 36. X-Ray Diffraction Pattern for Now Schumacher Candle - Sample 1 


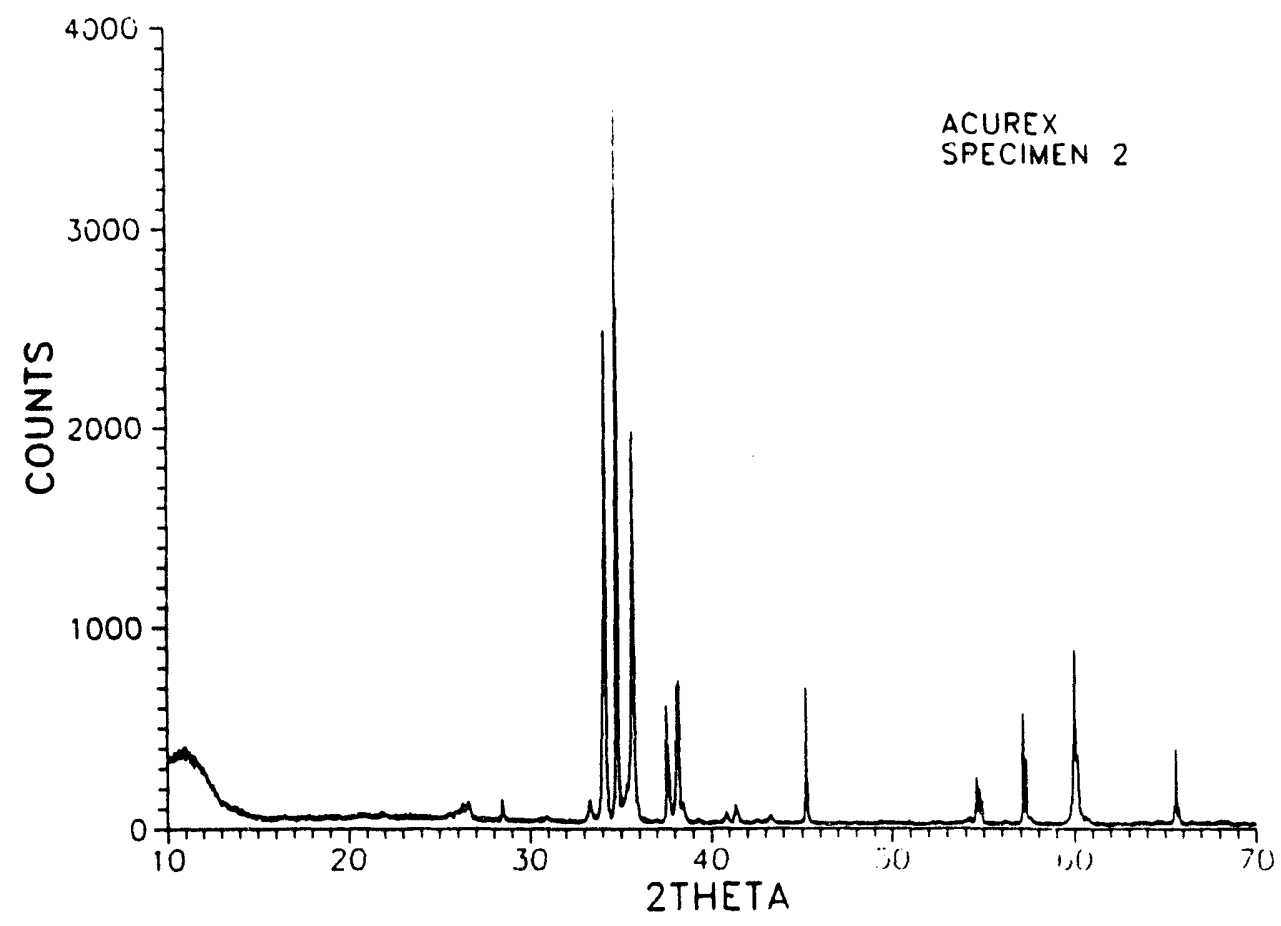

Figure 37. X-Ray Diffraction Pattern for New Schumacher Candle - Sample 2

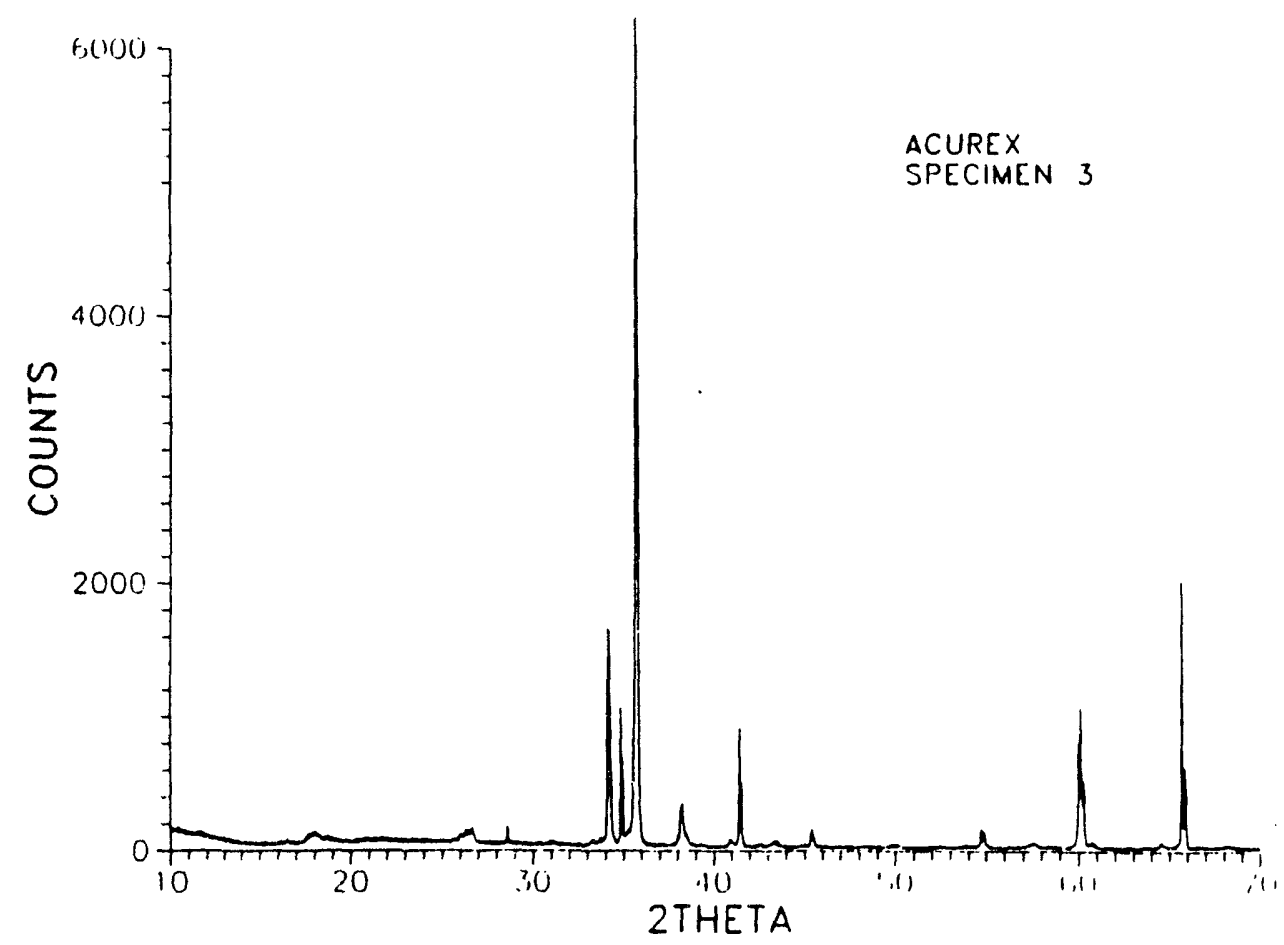

Figure 38. X-Ray Diffractlon Pattern for Now Schumacher Candle - Sample 3 


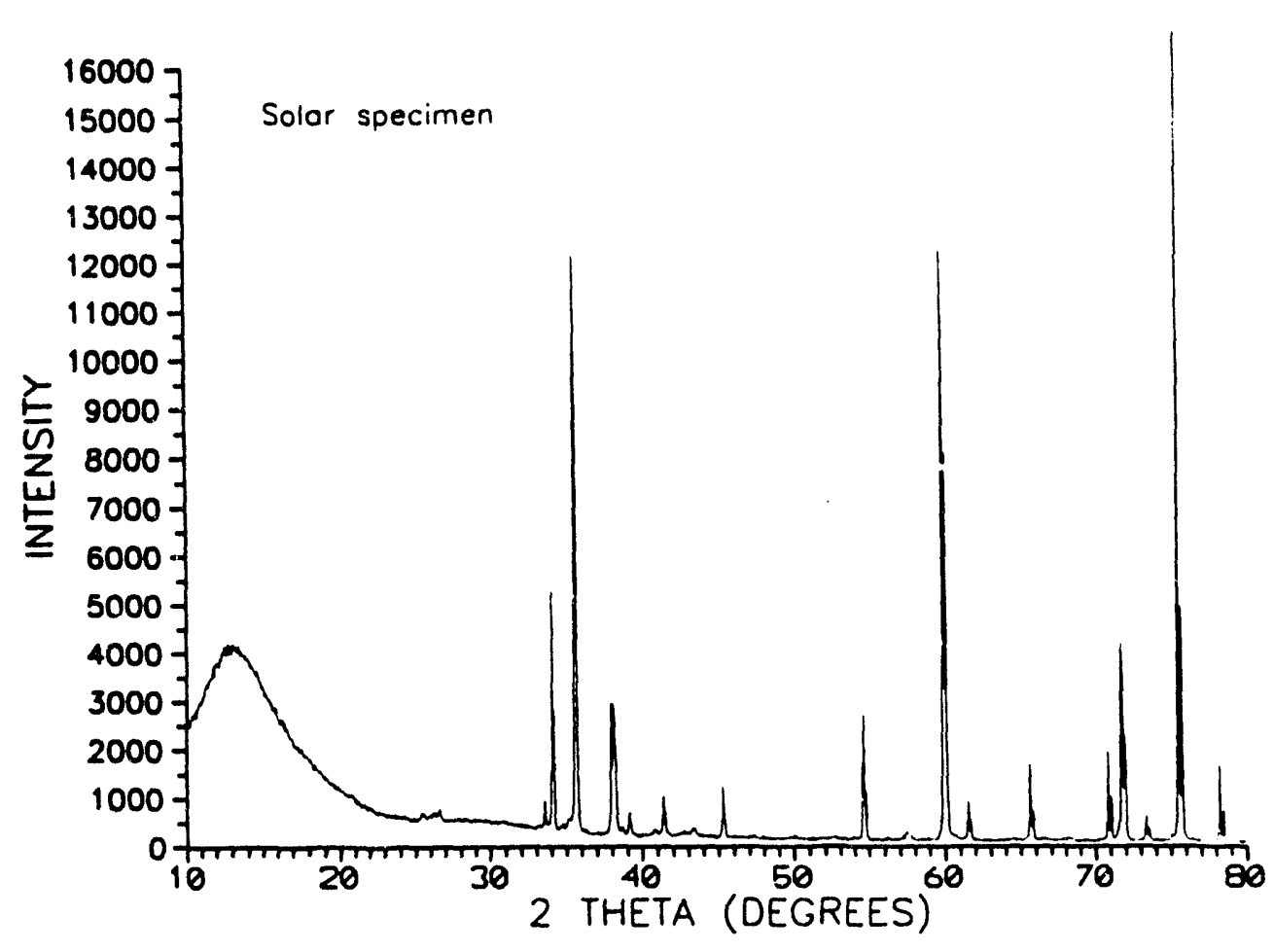

Figure 39. X-Ray Diffraction Pattern for Used Schumacher Candle

Vibrational phenomenon was a cause listed on the fault tree. Vibration data were collected for an unexposed and an exposed candie. In addition, a high speed dynamic pressure Klstler pressure transducer was mounted in the filter vessel and test data were collected to determine what frequencies were being generated by the combustor.

Two candles were taken to Solar's vlbration facility located at Sky Park in Kearny Mesa. One of the candles was exposed during the extended test, but was still intact. The other candle was an unexposed, virgin Schumacher dia-Schumalith. Frequency response curves were obtained for each candle.

The frequency response curves were obtained by placing the candle on two foam blocks to simulate a free-free system. An accelerometer was mounted on the flange of the virgiri candle and on the Hastelloy- $X$ cup for the exposed candle. An impedance hammer was used to strlke the candle in a fixed location five times. A microprocessor averaged the data. Each candle was struck with the hammer in locations that included both ends, and at 15, 30 and 45 inches from the top flange of the candle.

The data are summarized in Figure $\mathbf{4 0}$ for the unexposed or virgin candle, and in Figure 41 for the exposed candle. The virgin candles show much stronger responses whereas the exposed candle has been damped somewhat, perhaps by the presence of dust in the Interstices of the candle. The most active frequencies for the virgin candle are in the 200-400 Hz region. The lowest frequency at approximately $7 \mathrm{~Hz}$, responded at about 1.5 times the excitation; the most active response was at $414 \mathrm{~Hz}$ and at the flange end of the candle where 32.2 tmes the excitation was observed. These data are also displayed in Table 9 for both unexposed and exposed candles. 


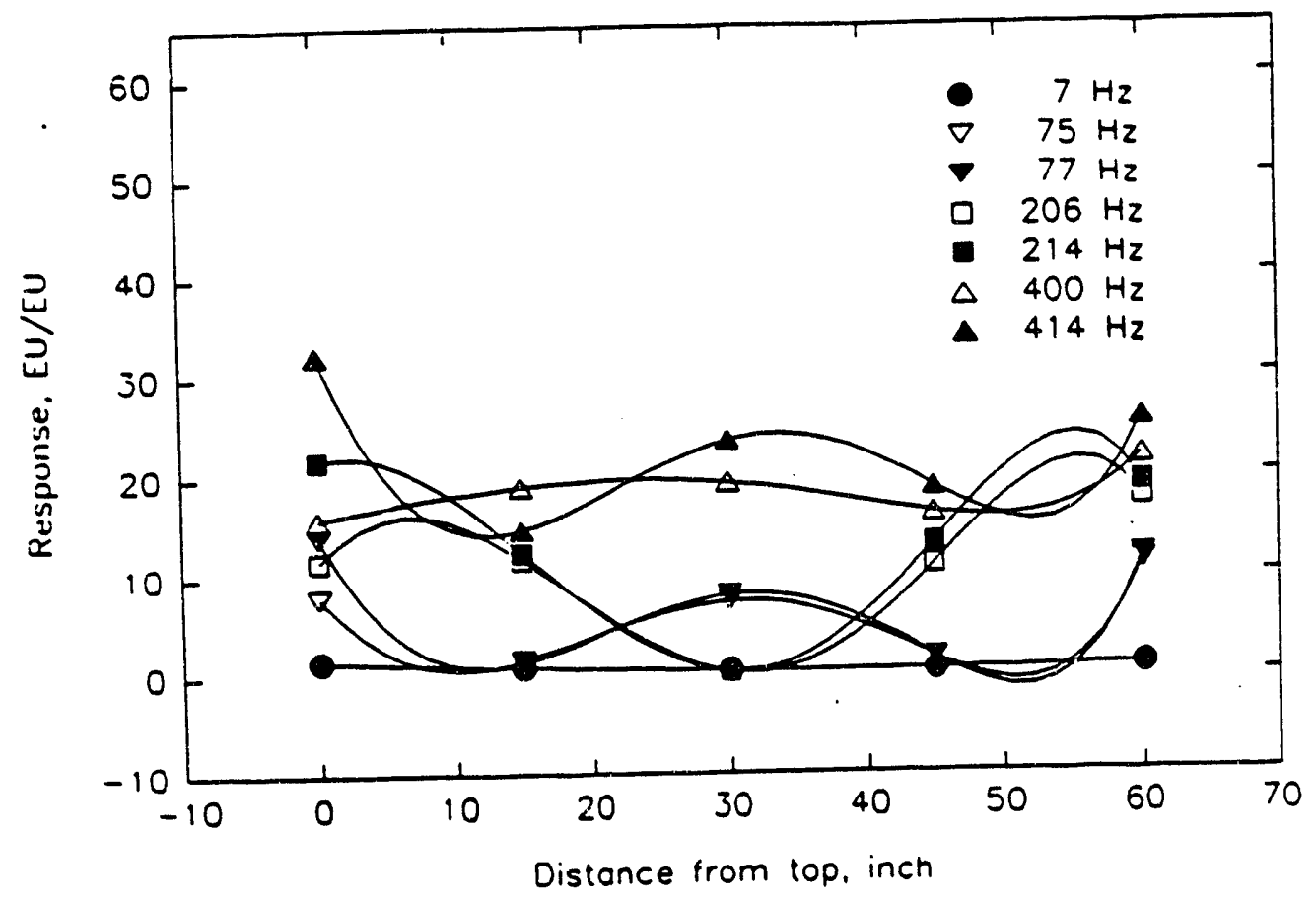

Figure 40. Frequency Response Curves for Virgin Candle

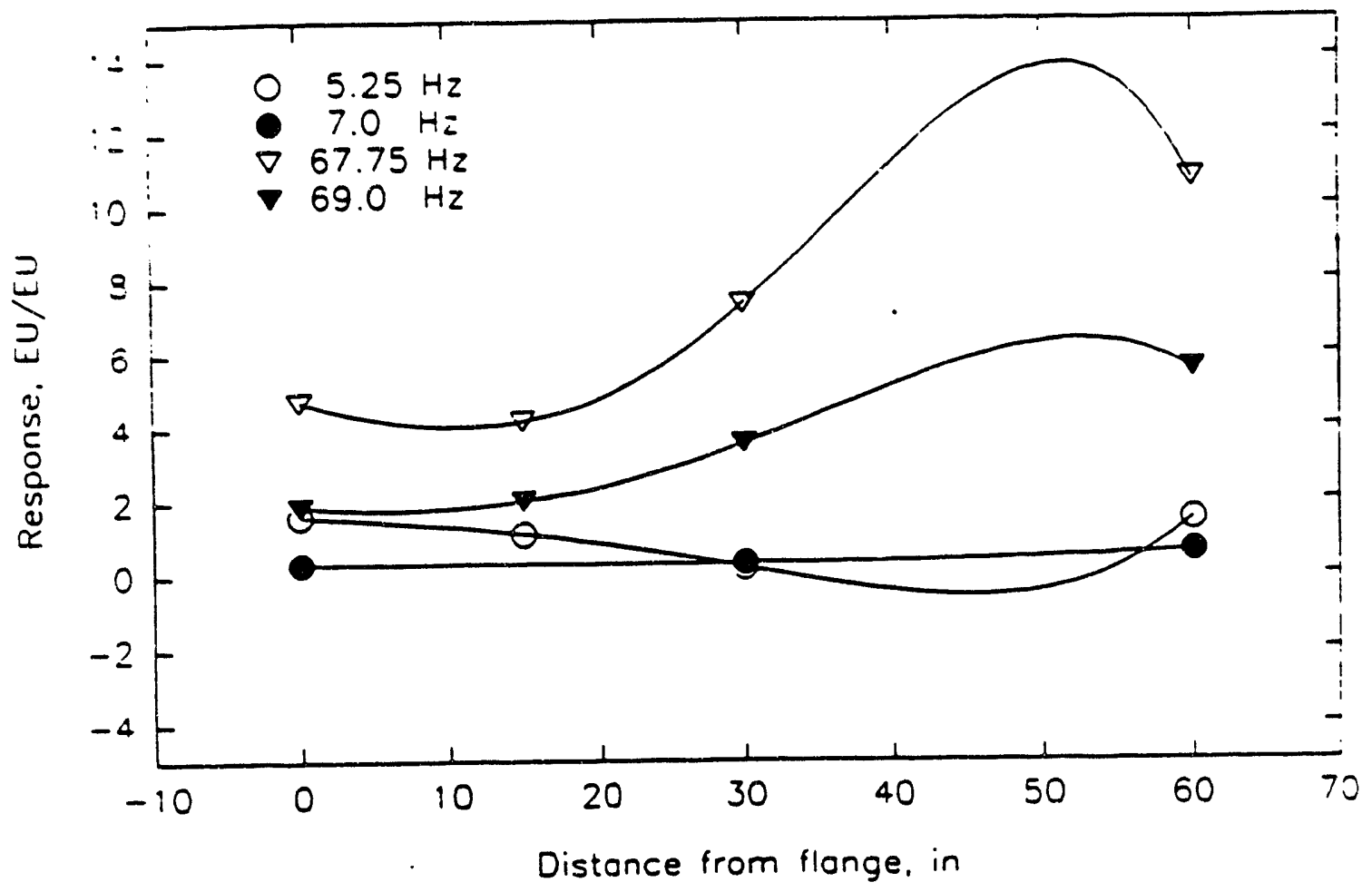

Figure 41. Frequency Response Curves for Exposed Candle 
Table 9. Resonant Frequency Data for Virgin and Exposed Candles

\begin{tabular}{|c|c|c|c|c|}
\hline \multirow[b]{2}{*}{$\begin{array}{l}\text { Distance from } \\
\text { Top Flange, In }\end{array}$} & \multicolumn{2}{|c|}{ Unexposed Candie } & \multicolumn{2}{|c|}{ Exposed Candle } \\
\hline & $\begin{array}{c}\text { Frequency, } \\
\text { Hz }\end{array}$ & $\begin{array}{c}\text { Response, } \\
\text { EU/EU }\end{array}$ & $\begin{array}{c}\text { Frequency, } \\
\mathrm{Hz}\end{array}$ & $\begin{array}{c}\text { Frequency, } \\
\mathrm{Hz}\end{array}$ \\
\hline 0 & $\begin{array}{c}7.5 \\
75 \\
77.5 \\
206.25 \\
213.75 \\
401.25 \\
413.75\end{array}$ & $\begin{array}{c}1.48 \\
7.98 \\
14.0 \\
11.6 \\
21.7 \\
15.8 \\
32.2\end{array}$ & $\begin{array}{l}5.25 \\
7.5 \\
67.75 \\
69.00\end{array}$ & $\begin{array}{l}1.60 \\
0.32 \\
4.75 \\
1.86\end{array}$ \\
\hline 15 & $\begin{array}{c}7.5 \\
77.5 \\
206.24 \\
213.75 \\
400.0 \\
413.75\end{array}$ & $\begin{array}{l}0.84 \\
1.57 \\
1.32\end{array}$ & $\begin{array}{l}5.25 \\
67.75 \\
69.0\end{array}$ & $\begin{array}{l}1.12 \\
4.21 \\
2.01\end{array}$ \\
\hline 30 & $\begin{array}{c}7.5 \\
75 \\
77.5 \\
207.5 \\
215.0 \\
401.25 \\
413.75\end{array}$ & $\begin{array}{c}0.45 \\
7.39 \\
8.05 \\
0.32 \\
0.31 \\
19.3 \\
23.5\end{array}$ & $\begin{array}{c}5.5 \\
7.25 \\
67.75 \\
69.0\end{array}$ & $\begin{array}{l}0.22 \\
0.33 \\
7.38 \\
3.58\end{array}$ \\
\hline 45 & $\begin{array}{c}6.25 \\
75.0 \\
78.75 \\
206.25 \\
213.75 \\
401.25 \\
413.75\end{array}$ & $\begin{array}{c}0.37 \\
1.48 \\
1.53 \\
10.9 \\
13.1 \\
16.1\end{array}$ & 69.0 & 0.41 \\
\hline 60 & $\begin{array}{c}6.25 \\
75.0 \\
78.75 \\
206.25 \\
213.75 \\
400.0 \\
41.375\end{array}$ & $\begin{array}{c}0.86 \\
11.2 \\
11.8 \\
17.6 \\
19.1 \\
21.8 \\
25.5\end{array}$ & $\begin{array}{l}5.26 \\
5.4 \\
6.8 \\
7.0 \\
67.75 \\
69.0\end{array}$ & $\begin{array}{c}1.49 \\
0.95 \\
0.63 \\
0.42 \\
10.7 \\
5.57\end{array}$ \\
\hline
\end{tabular}


A test was conducted at the IBSTF with diesel fuel \#2 to determined frequency response characteristics of the system. A fast-response Kistler pressure transducer was installed in the filter vessel using one of the window ports. The transducer housing was cooled; this permits measurements to be taken at fairty high temperatures. The signal from the piezoelectric transducer was amplified using a charge amplifier. The ampllfied signal was then input to a Spectral Dynamics spectrum analyzer. All noise was basically low frequency and below about $100 \mathrm{~Hz}$. In general, the pressure fluctuations were about \pm 0.1 psid. A graph of a typical trace is shown in Figure 42. While the pressure fluctuations were negligible in general, fluctuations as high as \pm 1 psi was observed, coincident with an aiplane taking off. The only significant datum from this test were the increased pressure fluctuations that were observed when planes were taking off. For this reason, a secondary experiment is currently under investigation to observe, solely, the effect of airport-generated noise on the strength of rigidly and non-rigidly mounted candles.

Another experiment was conducted with an accelerometer mounted on a candle in the Hot End Simulation Rig and with a microphone installed in the filter vessel. The experiment was, by necessity, conducted at atmospheric pressure and ambient temperature. However, at a face velocity of $6 \mathrm{ft} / \mathrm{min}$, there was considerable low frequency noise, particularly below $20 \mathrm{~Hz}$. A level of $104 \mathrm{~dB}$ was measured at about $10 \mathrm{~Hz}$. There was not much occurring above $20 \mathrm{~Hz}$, with the exception of some noise about $40 \mathrm{~Hz}$. It was pretty much lower intensity white noise above that with no pronounced specific frequencies. The candle manifested responses around $55 \mathrm{~Hz}$, and two peaks near $120 \mathrm{~Hz}$; one was about $115 \mathrm{~Hz}$, the other about $124 \mathrm{~Hz}$. The magnitudes of the responses wert $1 \times 10^{-3}$ for $55 \mathrm{~Hz}$ and $1 \times 10^{4}$ at $115 \mathrm{~Hz}$ and $124 \mathrm{~Hz}$. From this test, it did not appear that syistem noise was causing the candles to resonant to any appreciable extent.

The effect of the cooled tubesheet was of some concem. In the design phase of the barrier filter system, an ANSYS heat transfer analysis was performed to determine the types of temperature gradients the candle might experience. Effectively, the axial temperature gradients were discovered to occur over the first couple inches of the candle and were not at the point of failure. The location of the failures occurred at a point where the candle was already close to the gas stream temperature.

\section{Extended Candle Tests}

As the overall goal is to determine technical feasibility of using candle filters for a direct coal-fired gas turbine system. In order to attain this, it is necessary to first prove the system is viable for a relatively short period of about $50 \mathrm{hrs}$. Longer tests will eventually be necessary. Following the extended test of May 1990, a number of modifications have been made. First of all, in order to run the IBSTF within the County of San Diego, particulate emissions have to be kept below 0.1 grains/SCF (corrected to $12 \% \mathrm{CO}_{2}$ ), using a modified EPA method 5, which is even more stringent than EPA Method 5.

In order to meet these requirements, a venturl scrubber system was designed, constructed and commissioned. Tests have been erratic, and an operating permit has not yet been granted. Several tests have been conducted with both coal and diesel fuel \#2, and the standard was met 


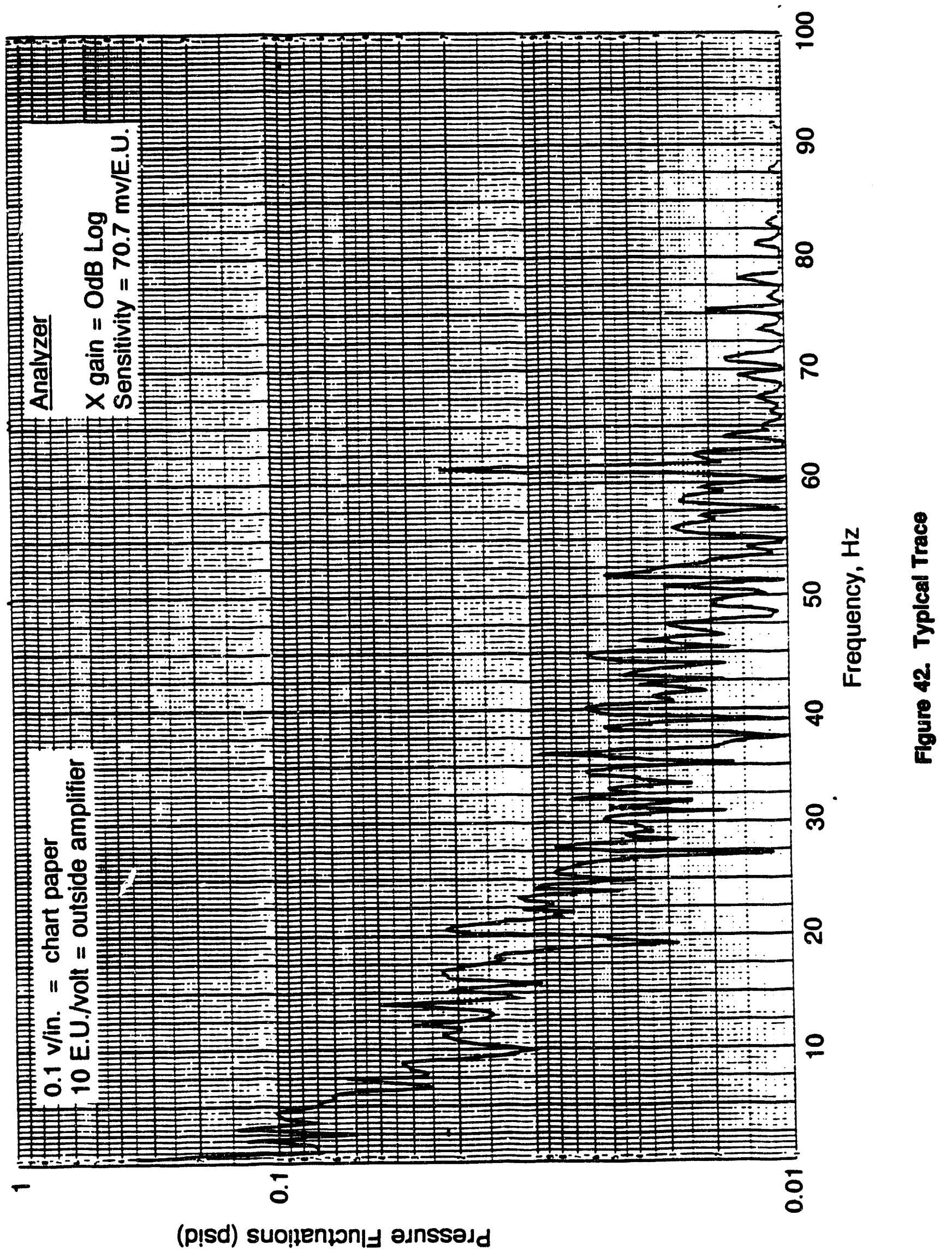


with diesel with dolomite injected, but has not yet been met with CWS. Modifications have been made to the system to improve performance. These include:

- Adding a filter system downstream of a hydrocyclone circult to remove micron and submicron size fines from the recycle water stream.

- Adding a strainer in the tubing that goes up to the venturi throat spray nozzles. This was added to remove particulate from the water injection spray so that it is not introduced again into the system.

- Replacing a pump that was used to boost pressure upstream of the hydrocyclones. The replacement pump is a centrifugal pump.

- Replacing the spray nozzles with a variety that is less likely to plug.

\section{Lean PRIS Evaluation}

The economic and technical feasibility of using candle filters is by no means assured. For this reason, alternate technologies are being considered. Recently, because of the success of the high temperature PRIS, a lean PRIS is being investigated as an altemate to a barrier filter device. Initial Investigations have been paper studies only with testing recommendations. The concept included addition of a glass-like material so as to make the ash sticky enough to adhere to the rods of an impact separator. The initial studies have included an analysis of the operating conditions, and factors that affect the selection of additives. Subsequent studies have included concepts to remove deposits. Dr. Arthur Metcalfe of Metcalfe and Associates, Inc., has been employed as a consultant for this work.

An initial analysis of the operating conditions showed that 2.5 times more material needs to be captured if dolomite is used rather than hydrated lime. This would indicate that if all things are equal, hydrated lime would be preferable. There are unresolved feeding problems with hydrated llme, however, and the particulate size distribution of hydrated lime is finer than dolomite, requiring removal of smaller particulate even though the total amount to be removed is less.

The sorbent selected can be a critical parameter. First of all, the quantity of particulate will vary by a factor of five based on experimental data. This data is shown in Table 10. Approximately 21 pounds of dolomite are required for $100 \mathrm{lbs}$ of coal whereas with hydrated lime, only $4.1 \mathrm{lbs}$ are required. The extra mass attendant to using dolomite has some disadvantages. For instance, an additional $2500 \mathrm{Btw} / 100-\mathrm{lb}$ dry coal is required to bring the added mass to $1900^{\circ} \mathrm{F}$. The heat of dissociation of the extra weight of carbonate, the work to drive the extra reactant into the pressurized system reduces the 4 cent advantage of dolomite to a negliglible amount. There is an added cost to dispose of additional material. Furthermore, a $99.6 \%$ collection efficiency is required when using dolomite to give an identical downstream concentration to a hydrated lime case with $99.0 \%$ collection efficiency.

Apparently, the nature of the particulates is less tractable to treatment by additives when dolomite is used. A review of Phase Diagrams for Ceramists shows no desirable additives that reduce the melting point of $\mathrm{MgO}$ from $5070^{\circ} \mathrm{F}$ to below $1900^{\circ} \mathrm{F}$. The large excess of dolomite that is added, as conversions are lower, ensures more unreacted $\mathrm{CaO}$ will be present; The high melting point 
Table 10. Addition of Sorbents Per 100 lbs of Coal to Desulfurize to $75 \mathrm{ppmw} \mathrm{SO}_{2}$

\begin{tabular}{|lllll|}
\hline Sorbent & \% Ca-specles & $\% \mathrm{Ca}$ & $\begin{array}{l}\text { Ratlo Ca/s } \\
\text { Requilred }\end{array}$ & $\begin{array}{l}\text { Welght/100 lbs } \\
\text { Coal Required }\end{array}$ \\
\hline Dolomite & $57.2 \% \mathrm{CaCO}_{3}$ & 22.9 & 3.4 & 20.8 \\
PHDL & $66 \% \mathrm{Ca}(\mathrm{OH})_{2}$ & 29.7 & 2.4 & 11.3 \\
HL & $95 \% \mathrm{Ca}(\mathrm{OH})_{2}$ & 51.4 & 1.5 & 4.1 \\
\hline
\end{tabular}

of $\mathrm{CaO}\left(\sim 4600^{\circ} \mathrm{F}\right)$ and the lack of strong melting point depressants for $\mathrm{CaO}$ is an additional factor against the use of dolomite.

A summary of reactants and products from using dolomite and hydrated lime appears in Table 11. The three principal products are unused $\mathrm{CaO}$, unused $\mathrm{MgO}$ and $\mathrm{CaSO}_{4}$. The highest melting material is $\mathrm{MgO}\left(5070^{\circ} \mathrm{F}\right)$ and it appears only in dolomite. Calcium oxide melts at $4600^{\circ} \mathrm{F}$ whereas calcium sulfate melts at $2640^{\circ} \mathrm{F}$.

Six approaches to improve lean PRIS capture at $1900^{\circ} \mathrm{F}$ were proposed. These approaches are the melt or fluid approach, the sticky particle approach, the co-deposition approach, the plastic particle approach, the sticky impactor approach, and the molten impactor approach.

In the melt or fluid approach, the lean PRIS would act in the same way as the rich PRIS form which the slag flow in a molten stream. In the sticky particle approach, material is added in sufficient quantity to react with each of the particles to make it "sticky". Each major group of particles would require a different reactant to make it sticky, unless complete reaction and homogenization occurs. Therefore, it is more likely that the additive will provide the same coating on each type of particle. In the co-deposition approach, an inherently sticky substance is added that would be co-deposited on the impact surface. No particle-to-particle reaction or coating within the gas stream would be necessary but once the co-deposit has been made, reaction could occur at that time. In the plastic particle approach, each particle is made plastic so that capture can be achieved by plastic flow at impact in the lean PRIS. This concept may or may not need additives. In the sticky impactor approach, an additive is used to coat the rods in the PRIS to achieve adherence. In the molten impactor approach, the impact surface is in actual fact, a viscous melt to ensure sticking.

In the melt or fluid approach, it is necessary to consider the type of sorbent used, since the viscosity of it differs considerably. The basic approach to modify ash viscosities are to consult the well-known Reld-Cohen correlations. These correlations show ash viscosities as a function of silica ratio, hence composition, and temperature. Thus, one could theoretically adjust the species that affect silica ratio $\left(\mathrm{SiO}_{2}, \mathrm{Fe}_{2} \mathrm{O}_{3}, \mathrm{CaO}\right.$, and $\left.\mathrm{MgO}\right)$ and obtain a specified viscosity at a given temperature. The sillca ratio of slag from the rich PRIS is about 0.53 . At $2700^{\circ} \mathrm{F}$, such a slag would have a viscosity of 10 poise. This is consistent with the behavior of the rich PRIS. The silica ratio of hydrated lime with entrained slag (slag not captured by the lean PRIS) is estimated to be 0.19 , which is much too low to form a glass. The addition of 0.48 lbs of sillica to 
Table 11. Reactants and Products from Dolomite and Hydrated Lime (per 100 lbs dry coal)

\begin{tabular}{|c|c|c|c|}
\hline \multicolumn{4}{|c|}{ HYDRATED LIME } \\
\hline \multicolumn{2}{|l|}{ Reactants } & \multicolumn{2}{|l|}{ Products } \\
\hline $\begin{array}{l}\text { Hydrated } \\
\text { lime }\end{array}$ & $4.1 \mathrm{lbs}$ & $\mathrm{CaSO}_{4}$ & $5.95 \mathrm{lbs}$ \\
\hline Sulfur & $1.4 \mathrm{lbs}$ & Residual HL & $0.64 \mathrm{lbs}$ \\
\hline Oxygen & $2.1 \mathrm{lbs}$ & (less water) & \\
\hline Total & $7.6 \mathrm{lbs}$ & $\begin{array}{l}\text { Net } \\
\text { Products }\end{array}$ & $6.6 \mathrm{lbs}$ \\
\hline Loss (water) & $1.0 \mathrm{lbs}$ & & \\
\hline $\begin{array}{l}\text { Not } \\
\text { Reactants }\end{array}$ & $6.6 \mathrm{lbs}$ & & \\
\hline \multicolumn{4}{|c|}{ DOLOMITE } \\
\hline Feactants & & Products & \\
\hline Dolomite & $20.8 \mathrm{lbs}$ & $\mathrm{CaSO}_{4}$ & $5.95 \mathrm{lbs}$ \\
\hline Sulfur & $1.4 \mathrm{lbs}$ & Unused CaO & $4.21 \mathrm{lbs}$ \\
\hline Oxygen & $2.1 \mathrm{lbs}$ & $\mathrm{MgO}$ & $4.22 \mathrm{lbs}$ \\
\hline Total & $24.3 \mathrm{lbs}$ & $\begin{array}{l}\text { Not } \\
\text { Products }\end{array}$ & 14.38 lbs \\
\hline Loss $\left(\mathrm{CO}_{2}\right)$ & 9.87 ibs & & \\
\hline $\begin{array}{l}\text { Net } \\
\text { Reactants }\end{array}$ & 14.43 Ibs & & \\
\hline
\end{tabular}

$0.88 \mathrm{lbs}$ of unreacted hydrated lime and $0.65 \mathrm{lbs}$ of slag, would raise the silica ratio to 0.4 ; this is safely within the glass forming range. To raise the silica ratio to 0.4 for dolomite sorbent, would require addition of $5.75 \mathrm{lbs}$ of silica to give $15.1 \mathrm{lbs}$ of modified slag. The viscosity would be 50 poise at $1900^{\circ} \mathrm{F}$, if all the constituents are melted and homogenized.

Several technical problems would need to be addressed with this approach. They include:

- Can reaction between added silica, unused sorbent, and entrained slag be completed in the 200 msecs dwell time to give the homogeneous melt that is required to obtain the minimum viscosity? 
- If such a melt can be formed, will it be capable of carrying $5.63 \mathrm{lbs}$ of CaSO $\mathrm{C}_{4}$ in $2.01 \mathrm{lbs}$ of melt (hydrated lime) or in $\mathbf{1 5 . 1} \mathrm{lbs}$ of melt (dolomite)?

One possibility that might be considered is to remove some of the calcium sulfate by an impact separation step prior to making the sillca addition to promote melt formation. This would only be possible with hydrated lime because the nature of the cake on the candle filters when dolomite is used Indicates this would probably not be adherent in an impact separator.

A "sticky" particle would be expected to have a viscosity of less than $10^{7.6}$ polse. A removal method other than gravity flow used in the rich PRIS would need to be devised. Reaction between the addittve, unused sorbent, entrained slag, and possibly with the calcium sulfate, will require to be uniform to generate particles with uniform compositions and similar degrees of stickiness. This is quite remote. A second possibility is to "coat" the particles and to assume that any subsequent reaction between the particle and its coating would be small in the maximum avallable time of $\mathbf{2 0 0}$ msec.

In the co-deposition approach, an additive is chosen that is itself sticky. Thus, it does not require reaction with other species. This is similar in nature to the "sticky impactor" approach and is discussed more fully in conjunction with that approach.

In the plastic particle approach, many of the particulates to be trapped are lonic solids, such as $\mathrm{CaO}, \mathrm{MgO}$, and $\mathrm{CaSO}_{4}$. Ionic crystals become plastic at a temperature above $0.5 \mathrm{~T}_{M}$ where $\mathrm{T}_{M}$ is the melting point in absolute temperature units. $T_{M}$ values for a few selected compounds are shown in Table 12. These are the temperatures for the onset of ductility. Two oxides, $\mathrm{CaO}$ and $\mathrm{MgO}$ are likely to behave as brittle, elastic solids at $1900^{\circ} \mathrm{F}$ whereas $\mathrm{CaSO}_{4}$ may be somewhat plastic. Calclum sulfate behaves plastically in the $1000-1500^{\circ} \mathrm{F}$ range.

If the melting points of $\mathrm{MgO}$ and $\mathrm{CaO}$ were reduced below $4000^{\circ} \mathrm{F}\left(0.5 \mathrm{~T}_{M}=1770^{\circ} \mathrm{F}\right)$ by reaction with additives, then plastic behavior of these new solids might be sufficiently plastic to adhere to the Impact surface in the lean PRIS. However, the problem becomes one of ensuring enough reaction with all of the particles to form the new solids.

Table 12. Melting Polnts and Values of $0.5 \mathrm{~T}_{\mathrm{m}}$ for Selected lonic Sollds

\begin{tabular}{|ccc|}
\hline Composition & Molting Polnt, ${ }^{\circ} \mathrm{F}$ & $0.5 \mathrm{~T}_{\mathrm{M}}{ }^{\circ} \mathrm{F}$ \\
\hline $\mathrm{MgO}$ & 5070 & 2305 \\
$\mathrm{CaO}$ & 4600 & 2071 \\
$\mathrm{CaSO}_{4}$ & 2640 & 1091 \\
$\mathrm{NaCl}$ & 1474 & 507 \\
\hline
\end{tabular}


In the sticky impactor approach, impact surfaces would be maintained in a sticky condition by application of a low melting point/low viscosity fluid. The composition could be one of those given in Table 13. The rate of application required can be estimated by assuming that the particles are all of equal size, spherical, and form a close-packed array. In this situation, the interstices consttute $35 \%$ by volume of the particles. For a first simplified calculation, we can assume the densities of the two particles are equal and then the deposit on the impact surface for the two sorbents will be as follows:

Table 13. Quantitles of Materials for Stlcky Impactor

\begin{tabular}{||ll|}
\hline \multicolumn{1}{|c|}{ Dolomite } & \multicolumn{1}{c|}{ Sorbent } \\
\hline 5.36 lbs CaSO, & 5.36 lbs Caso, \\
4.45 lbs unused CaO & 0.88 lbs unreacted CaO \\
4.22 lbs MgO & 0.65 lbs entrained slag \\
0.65 lbs entrained slag & 2.41 lbs sticky binder \\
5.14 lbs sticky binder & \\
\hline 19.82 lbs total & 9.30 lbs total \\
\hline
\end{tabular}

If calcium sulfate is assumed self-sticking, then the sticky binder will be needed for the entralned slag and unreacted calcium oxide. This lowers the required sticky binder to 3.26 lbs for the dolomite case and to $0.54 \mathrm{lbs}$ for the hydrated lime case. The method of application of the "sticky" binder might be via the co-deposition approach or by some other application method.

In the molten impactor concept, particles would impact on a molten surface that would transport the particles away by flow with possible purfication and recycle of the molten material. The molten surface would need to have adequate viscosity to withstand the aerodynamic drag. The most likely candidate for the molten material is a viscous sillica-based glass. Potential problems might include the necessity for constant additions of silice to keep the silica ratio at the desired lovel.

Also, the working range at $1900^{\circ} \mathrm{F}$ of silica glasses is small. Additions of viscosity-reducing glass formers such as $\mathrm{B}_{2} \mathrm{O}_{5}$ and $\mathrm{CaF}_{2}$ would be essential. Also, the lean PRIS would require considerable monitoring to control the melt as the composition of the slurry changes, and as the load on the turbine varies. 


\section{PHASE il - TASK 4 - COAL FUEL SPECIFCATION DEVELOPMENT}

\subsection{SPECIFIC ITEMS OF PROGRESS}

- Coal slumies tested in the combustor rigs were varied with wide ranges of fuel speclfications:

- Coal loadings in slumies have been extended from 43.4 to 60.6 wt\%, and ash contents from 2.3 to $12.8 \mathrm{wt} \%$.

- Varieties of coal sources with low volatile matter $25.8 \%$ in Upper Freeport coal) to high volatile matter ( $39.4 \%$ in Utah's Soldier Creok coal) have been tested.

- Coal particle sizes in the slurries have ranged from 25 to $100 \mu \mathrm{m}$ with the mean size between 7.3 to $21 \mu \mathrm{m}$.

- Ash fluld fusion temperatures (under reducing conditions) were extended to a wider range between 2300 to $2700^{\circ} \mathrm{F}$.

- Twelve combustion testing fuels have been prepared and tested completely in the subscale combustor.

- The test fuels were prepared with varieties of fuel specifications such as coal rank/reactivity, coal loading, ash content, particle size, and ash fusion temperature.

- The combustion results showed that TSSC was capable of utilizing wide ranges of coal specifications without deteriorating the combustion performance.

- The slag samples collected from the primary-zone were diluted and contaminated by the refractory.

- The slag samples collected from the PRIS showed less enrichment with refractory alumina, but retained a significant amount of sodium.

- The slag droplets collected from the water-quenched slag pit were brittle, shining, black spherical glassy materials with fused surface.

- Analyses of the candie dust indicated spent sorbent acting as a capture for coal alkali.

- Laboratory analyses showed that iron present in the slag was responsible for the attack at the worn PRIS silicon carbide rods. 
- The leachable motal toxicity tests for studying the slag and candle dust disposal showed the extract metal concentrations well below the published EPA regulatory levels.

- Analyses of a water sample from the water-quenched slag plt showed no significant elements leached during the slag quench operation.

- Slurry was prepared on-site by the leasing of a unit from a Drals grinding mill and slumying system.

- The properties of slurry prepared on-site by Drais Mill were largely dependent on the grinding media, feed rate, coal particle size and hardness, coal loading, and dispersant used.

- Initial and finish grinding tests were completed and the results were utilized for the design and operating criteria of slumy fuel preparation and for the fuel cost projection.

- The first bulk lot (4500 gallons) of slumy prepared by AMAX R\&D has been shipped to Peoria for the full-scale combustion testing:

- The specified properties of bulk-lot slurry were based on the design goals and the operating experience from combustor rig testing.

- The properties of bulk-lot slumy were checked and ensured after seven weeks of storage before the first full-scale combustor testing.

- Precautions of slumy handling and slumy waste treatment were taken and a handling procedure was prepared for the full-scale huel system.

- A new agitator system was evaluated for installing in the fuel storage tank.

- Fuel costs were updated and projected in a spreadsheet on various scenarios to supply fuels for a coal-hueled Centaur Type H gas turbine cogeneration system.

\subsection{DISCUSSION}

\subsubsection{Coal Fuel Specifications}

\section{Fuel Speciflcation}

Coal slumies tested in the subscale combustor ings were varied with wide ranges of fuel specifications. Table 14 updates the ranges of CWM properties and compositions tested so far at Solar's TSSC. The majortty of slurry huels were formulated from eastern Kentucky coals, except that a Pittsburgh-seam Powhatan coal that has been used in the sorbent injection testing. Recently, in the combustor performance runs slurries made from the Upper Freeport coal (in Pennsylvania), Ilinois \#6 coal, and Utah's Soldler Creek coal have also been tested. The Upper 
Table 14. Ranges of CWM Fuel Properties Tested at Solar

\begin{tabular}{|ll|}
\hline Slurry Loading & $43.4-60.6 \mathrm{wt} \%$ \\
Ash Content (Coal Basis) & $2.3-12.8 \mathrm{wt} \%$ \\
Particle Size & \\
Top Size & $25-100 \mu \mathrm{m}$ \\
Mean Size & $7.3-21 \mu \mathrm{m}$ \\
Slurry Viscosity (100 sec ${ }^{-1}$ ) & $150-470 \mathrm{cp}$ \\
Slurry Heating Value (LHV) & $5452-7801 \mathrm{Btu} / \mathrm{lb}$ \\
Volatile Matter (Coal Basis) & $25.8-39.4 \mathrm{wt} \%$ \\
Sulfur Content (Coal Basis) & $0.43-3.26 \mathrm{wt} \%$ \\
Nitrogen Content (Coal Basis) & $1.02-2.19 \mathrm{wt} \%$ \\
Alkall Content (Coal Ash Basis) & \\
NazO & $0.3-2.6 \mathrm{wt} \%$ \\
K2O & $0.3-2.7 \mathrm{wt} \%$ \\
Ash Fluid Fusion Temperature & \\
Reducing & $2300-2700+{ }^{\circ} \mathrm{F}$ \\
Oxidizing & $2500-2700+{ }^{\circ} \mathrm{F}$ \\
\hline
\end{tabular}

Freeport coal contains a relatively low volatile matter (25.8 wt\%) compared to the baseline fuel $(-35 \%)$, while the Soldier Creek coal has a high volatile $(39.4 \%)$. TSSC combusted the slumy formulated from the low-volatile coal satisfactorily without any difficulty. Accepting a lower volatlle content could widen the selection of coal source. Centain attractive coals with low sulfur in the West Virginia/Kentucky areas have below $30 \%$ of volatile matter.

Slurries with the coal loading from 43.4 to 60.6 wt\% and the ash content from 2.3 to 12.8 wt\% have been tested in Solar's combustor ings. It appears again that Solar's two-stage slagging combusior design can tolerate wide ranges of coal loading and ash content without noticeable impact on combustor performance. A higher coal ash did result in faster refractory degradation and in increasing the slag coating and accumulation on the combustor wall. The combustor test results also showed the TSSC was capable of utilizing wide ranges of coal particle size and had Ilttle ill effects on the combustor performance. The coal particle sizes in the slumies have been ranged from 25 to $100 \mu \mathrm{m}$ with the mean size between 7.3 to $21 \mu \mathrm{m}$.

The slurry viscosity was maintained around 200-300 cp @ 100 ser. $^{-1}$ with emphasis on lowering the amount of stabilizer used. The sulfur in coal varied from 0.43 to $3.26 \%$. Illinois \#6 coal with sulfur content at $2.61 \%$ (on ash-free dry coal basis) has been used in one of the combustor performance fuel. The alkali content (on coal ash basis) was ranged from 0.3 to $2.6 \%$ of $\mathrm{Na}_{2} \mathrm{O}$ and 0.3 to $2.7 \%$ of $\mathrm{K}_{2} \mathrm{O}$, respectively. This is corresponding to about 82 to $978 \mathrm{ppm}$ of total alkali 
content in the slumy feed. Ash fluid fusion temperature has been extended to a wider range between 2300 to $2700^{\circ} \mathrm{F}$ (under reducing conditions) in the most sattsfied operation when a water quench bath used for the slag capture.

Based on the design goals and the operating experience from the combustor ing testing, the first bulk lot ( 4500 gallons) of stumy fuel has been prepared at AMAX R\&D and shipped to Peoria for the full-scale combustor testing. Table 15 summarizes the important slumy properties present in the full-scale testing fuel. The slumy was formulated by blending Kentucky $4 A$ and Elkhom coals with approximately 54 wt\% loading and $2.9 \%$ ash content. The top particle size in slumy was 98.7\% passing $45 \mu \mathrm{m}$ and $99.9 \%$ passing $75 \mu \mathrm{m}$ with the mean size of $11.9 \mu \mathrm{m}$. The slumy viscosittes were around $210 \mathrm{cp} @ 100 \mathrm{sec}^{-1}$ and $305 \mathrm{cp} @ 1000 \mathrm{sec}^{-1}$. The slumy coal contains $0.76 \%$ sulfur (on ash-free dry coal basis) and $0.63 \% \mathrm{Na}_{2} \mathrm{O}$ and $1.08 \% \mathrm{~K}_{2} \mathrm{O}$ (on coal ash basis), respectively. Ash fluid fusion temperature (under reducing conditions) was adjusted with a small amount of Hemattte addittve to remain below $2500^{\circ} \mathrm{F}$. Flocon stabilizer $(0.1 \%$ on coal basis) and A-23 dispersant ( $1 \%$ on coal basis) were also added to ensure the stability of slurry for the large quantity and long period storage.

Table 15. Slurry Propertles for Full-Scale Combustor Testing

\begin{tabular}{|c|c|}
\hline Batch & $\mathbf{w}$ \\
\hline Coal Source & Kentucky 4AElkhorn \\
\hline Slurry Loading & $54.1 w t \%$ \\
\hline Ash Content & 2.94\% (Slumy Basis) \\
\hline $\begin{array}{l}\text { Particle Size } \\
\text { Top Size } \\
\text { Mean Size }\end{array}$ & $\begin{array}{l}45 \mu \mathrm{m} \text { (98.7\% passing) } \\
11.9 \mu \mathrm{m}\end{array}$ \\
\hline $\begin{array}{l}\text { Slurry Viscosity } \\
@ 100 \sec ^{-1} \\
@ 1000 \mathrm{sec}^{-1}\end{array}$ & $\begin{array}{l}210 \mathrm{cp} \\
305 \mathrm{cp}\end{array}$ \\
\hline Slurry LHV & 7064 Btw/lb \\
\hline Volatile Matter & $34.33 \%$ (Coal basis) \\
\hline Sulfur Content & $0.75 \%$ (Coal basis) \\
\hline Nitrogen Content & $1.48 \%$ (Coal basis) \\
\hline $\begin{array}{l}\text { Alkall Content, } \\
\mathrm{Na}_{2} \mathrm{O} \\
\mathrm{K}_{2} \mathrm{O}\end{array}$ & $\begin{array}{l}0.63 \% \text { (Coal Ash basis) } \\
1.08 \% \text { (Coal Ash basis) }\end{array}$ \\
\hline $\begin{array}{l}\text { Ash Fluid Fusion Temperature } \\
\text { Reducing } \\
\text { Oxidizing }\end{array}$ & $\begin{array}{l}2497^{\circ} \mathrm{F} \\
2655^{\circ} \mathrm{F}\end{array}$ \\
\hline
\end{tabular}


A summany of CWM fuel properties tested at Solar's combustor rigs (TSSC, IBSTF and HESR) and full-scale combustor is listed in Appendix A.

\section{Combustion Testing Fuels}

Twelve combustion testing fuels have been prepared and tested in the subscale combustor. Table 16 compares and summarizes the tuel properties, composition, and coal sources. The baseline fuels (S-1 and S-2) were prepared from the blend of Kentucky 4AVEkhom coals with or without the addition of stabilizer. S-3, S-4 and S-5 were prepared with different coal loading. S-3 and S-5 have blended coarsely and finely ground slurries to achieve the "bimodal" effect for obtaining a high solids loading. S-3 was formulated at $58.2 \%$ coal and S-4 at $50 \%$ loading, while S-5 prepared without dispersant and stabilizer only could reach $43.4 \%$ coal loading.

S-6 and S-7 were prepared with higher ash contents where S-6 slumy contained $4.80 \%$ ash (or $8.84 \%$ ash on dry coal basis) and $S-7$ contained $6.96 \%$ ash (or $12.81 \%$ on dry coal basis). These two coal ash contents are about double or triple amounts of baseline fuel. S-8 had a particle top size of $25 \mu \mathrm{m}$ and mean size of $7.3 \mu \mathrm{m}$ and S-9 had $50 \mu \mathrm{m}$ and $15.4 \mu \mathrm{m}$, respectively.

The last three slumy tuels, S-10, 11, and 12 were prepared from different ranks and reactivities of coals including a medium volatile Upper Freeport, a western Utah bituminous, and a midwestem Illinois No.6, respectively. Upper Freeport's medium volatile coal contains about $26 \%$ volatile matter compared to about $35 \%$ in eastern Kentucky coals. One of our earty studies on coal source selection indicated that bituminous coal trom Utah appears to have the best potential for consumption in the Callfomia market. And, llinois Basin coals represent the most economic coal sources for the midwestem coal-fired gas turbine markets.

As shown, the above test fuels were prepared with varieties of fuel specifications such as coal rank/reactivity, coal loading, ash content, particle size, and ash fusion temperature. The combustion results indicated that Solar's two-stage slagging combustor could tolerate these differences of fuel properties without deteriorating the performance.

\section{Slag Composition and Charactertzation}

The chentcal and physical composition and properties of ash slag are critical to successful direct combustion of coal as it reflected the very nature of the slagging combustor. All slag properties fusion temperature, viscosity, surface tension, thermal properties - will relate back to the ash composition of parent coal and the thermal history during the slag formation.

The appearance of slag samples from the combustor depends on the location where the slag collected. The slag droplets collected in the water quenched slag pit are nearly black, glassy materials with fused surface. These droplets are brittle, shinning spherical particles with a dlameter about $5-7 \mathrm{~mm}$. Some of these droplets can be srushed by finger pressure without difficulty.

Water-quenched slags collected from the combustor performance fuel tests (S-1 to S-12) were examined for their composition and slag fusion characterization. The slag composition and ash fusion properties are reported in Table 17. In general, the slag samples were high in alumina compared to their parent coal ashes. The slag samples also appear gaining some $\mathrm{Fe}_{2} \mathrm{O}_{3}$ and 


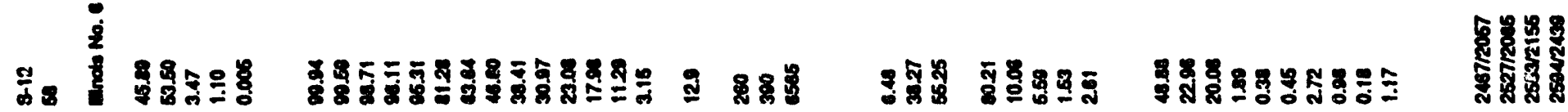

ह

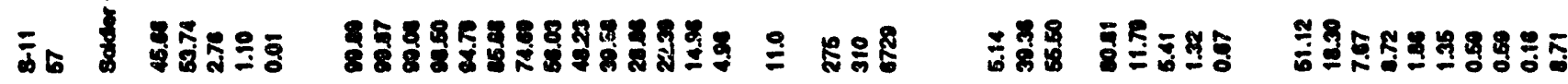

을 쫀

สำ

8

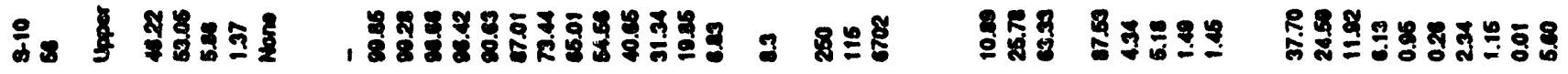

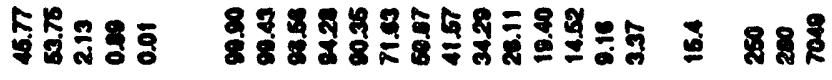

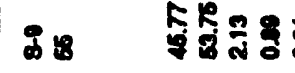

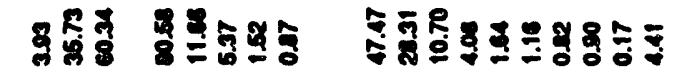

ํํำ

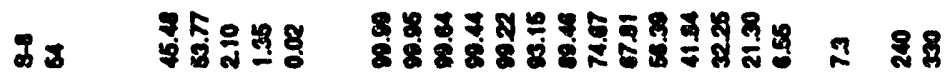

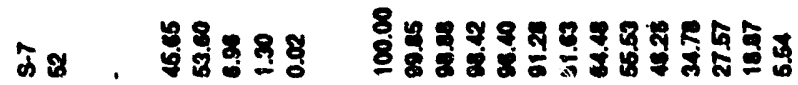

288

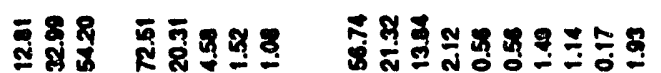

$8 \%$

มั

मะ

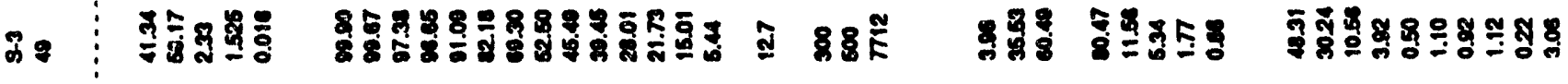

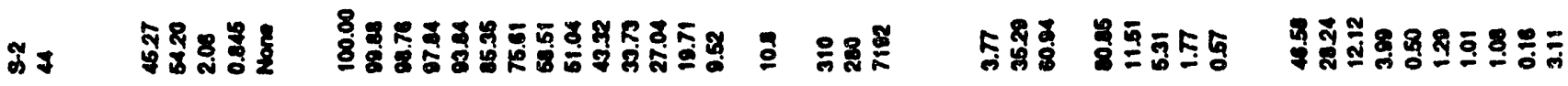

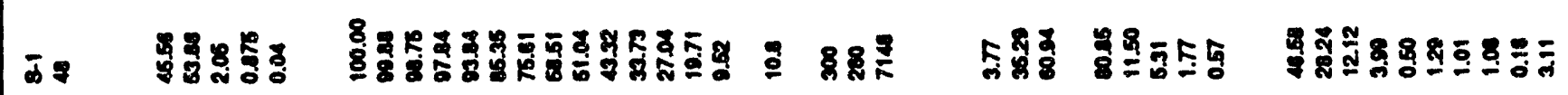

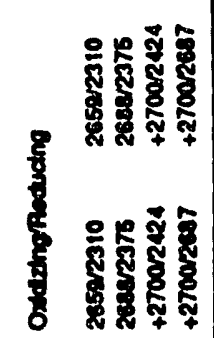

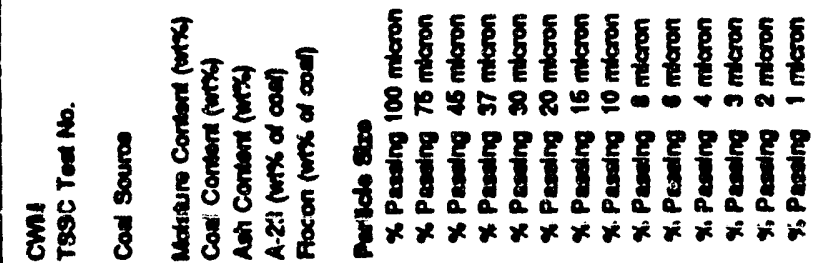
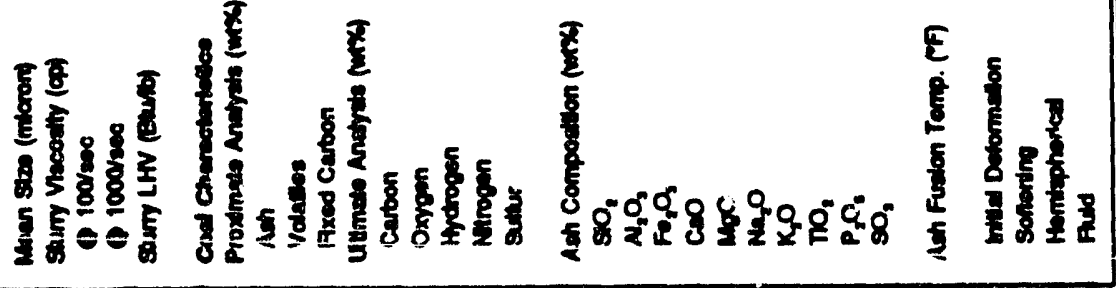


\begin{tabular}{|c|c|c|c|c|}
\hline$\frac{N}{\omega} \frac{8}{\omega}$ & 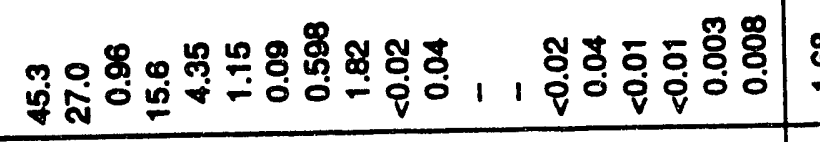 & $\stackrel{\leftrightarrow}{-}$ & జ్ల్ర & 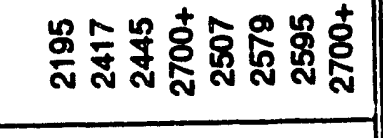 \\
\hline$\overline{\bar{\sigma}} \frac{\mathrm{g}}{\omega}$ & 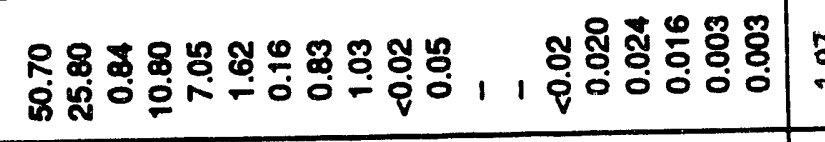 & $\stackrel{\Phi}{\Phi}$ & $\underset{4}{0}$ & 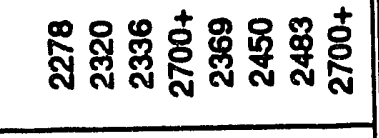 \\
\hline 웋 & 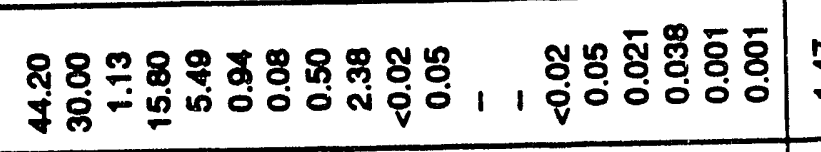 & \pm & ס్ & 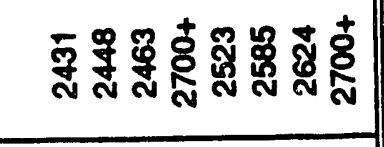 \\
\hline $2 \frac{0}{6}$ & 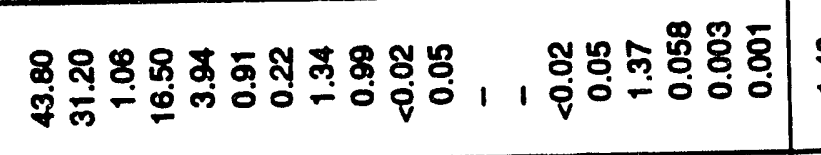 & $\stackrel{?}{?}$ & $\overline{0}$ & 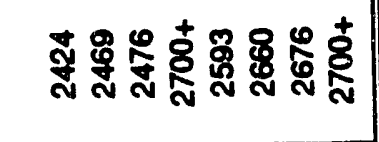 \\
\hline$\frac{9}{5}$ & 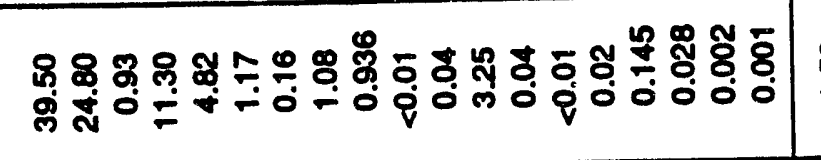 & $\stackrel{\leftrightarrow}{\leftrightarrow:}$ & 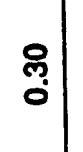 & 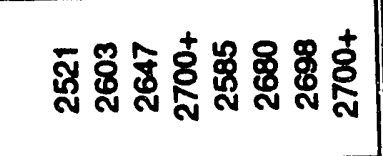 \\
\hline के & 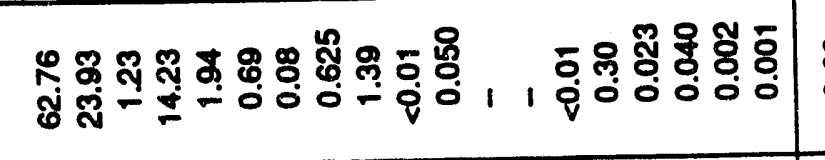 & $\underset{\text { ஸे }}{~}$ & $\frac{9}{\circ}$ & 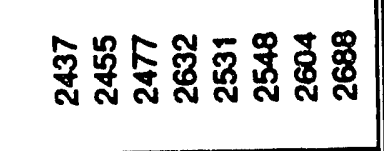 \\
\hline $9 \frac{\mathrm{g}}{\omega}$ & 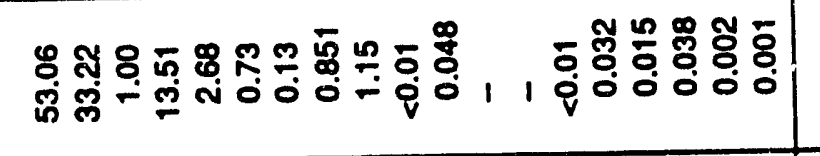 & $\stackrel{8}{-}$ & $\stackrel{\circ}{\circ}$ & 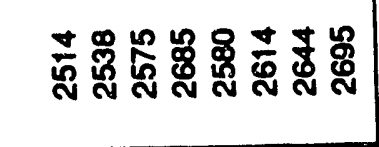 \\
\hline g. & 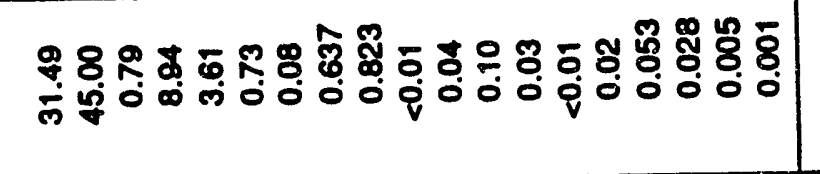 & $\stackrel{R}{0}$ & $\stackrel{9}{0}$ & 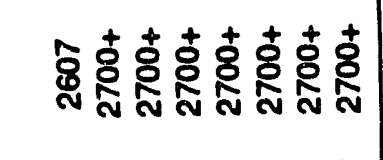 \\
\hline J & 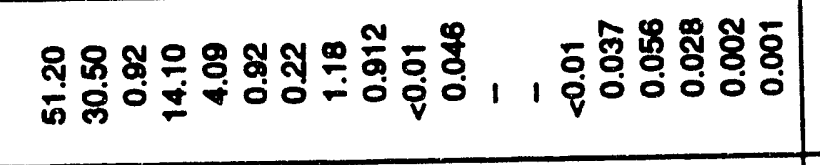 & $\stackrel{8}{-}$ & 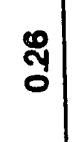 & 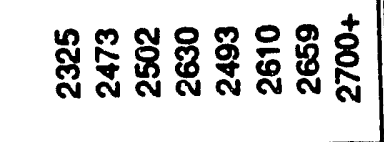 \\
\hline कั & 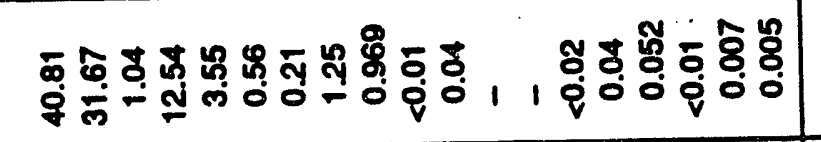 & בุ & ఫ్ర & 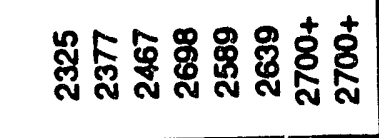 \\
\hline $\bar{\omega} \frac{0}{\omega}$ & 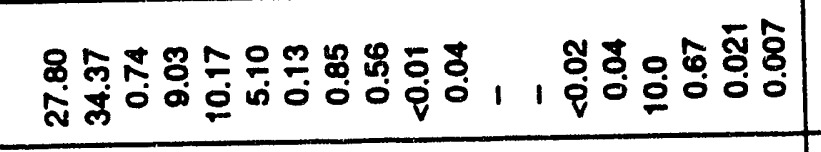 & ळ. & $\bar{\sigma}$ & 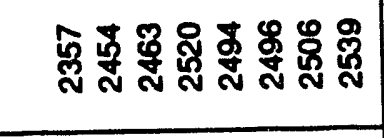 \\
\hline & 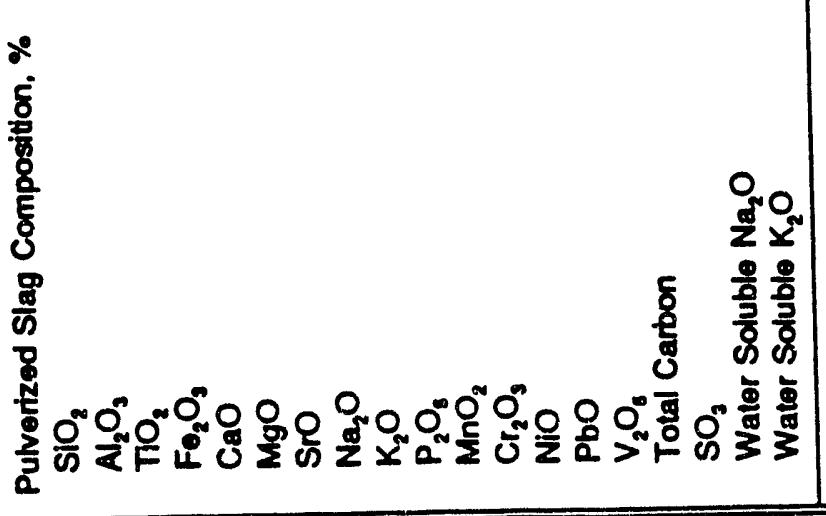 & 위ำ: & 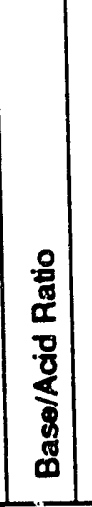 & 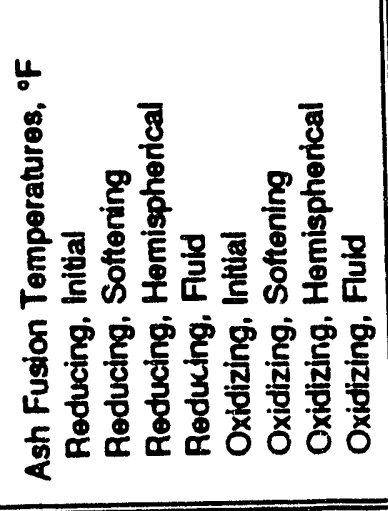 \\
\hline
\end{tabular}


alkall $\mathrm{Ne}_{2} \mathrm{O}$ and $\mathrm{K}_{2} \mathrm{O}$. The analyses of $\mathrm{SiO}_{2} / \mathrm{Al}_{2} \mathrm{O}_{3}$ ratio showed that the slags were diluted and contaminated by the refractory. Higher fludd temperatures in slag samples (determined by ASTM measurement) further Indicated alumina contamination in slags from the refractory. The slag from S-8 tuel contained 3.25\% $\mathrm{Cr}_{2} \mathrm{O}_{3}$ which could come either from the refractory used in the impactor or from metal worn off the chromium steel balls used during the extra fine grinding operation.

Three slag samples collected after IBSTF No.9 duration test were examined for their composition and fusion properties (Table 18). Among slags, one was obtained from the primary-zone slag pit and the other two samples were taken from PRIS's slag outlet and wall, respectively. As shown in Table 18, the primary-zone slag was high in alumina indicating the contamination of refractory. However, the slag samples from the PRIS area showed lesser enrichment in alumina

Table 18. Propertles of Primary-Zone and PAIS Slags

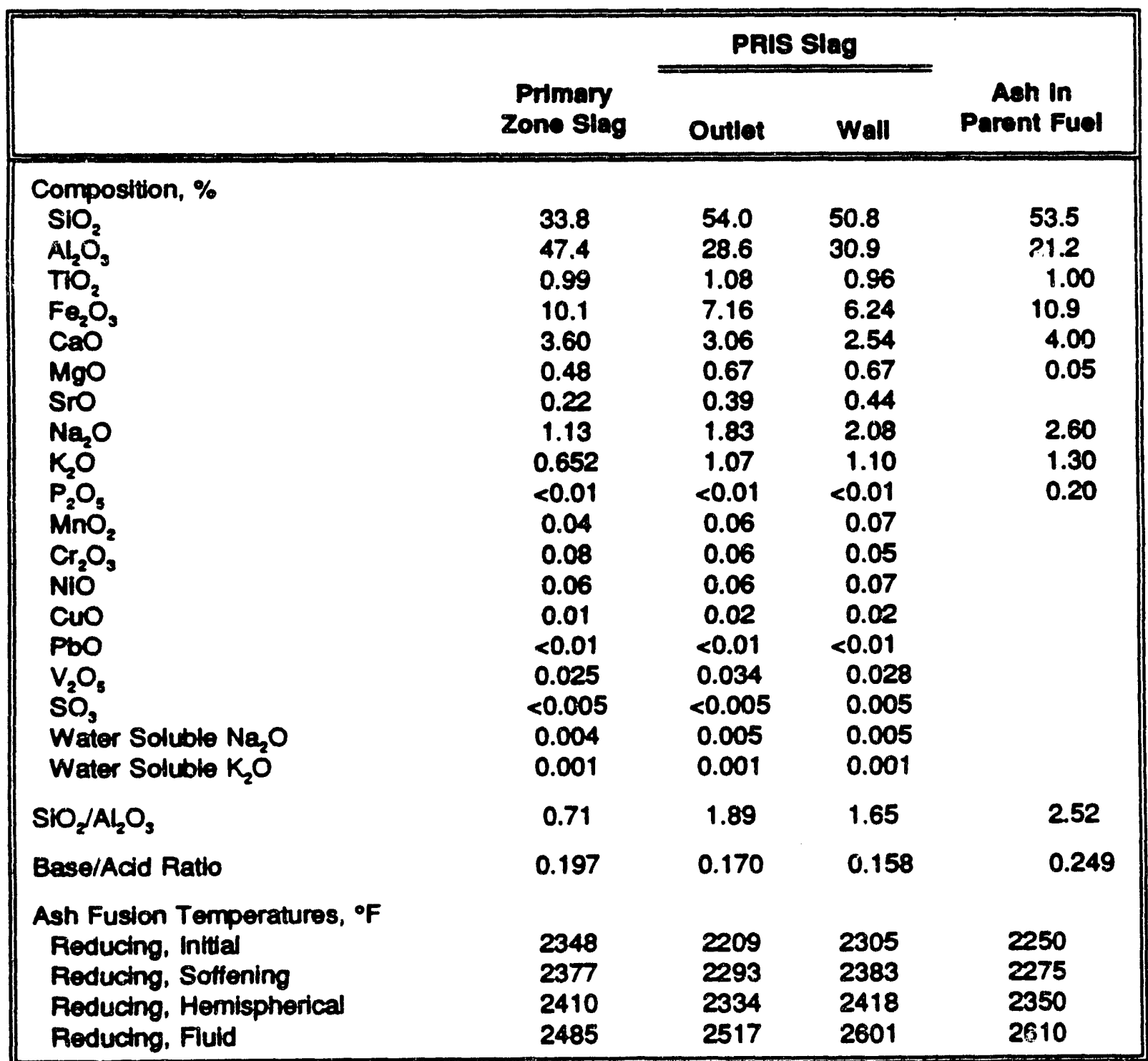


compared to the coal fuel ash. Significant amounts of sodium were retained in slags, as observed $1.13 \%$ is primery-zone slag and $1.83-2.08 \%$ is PRIS slags, despite the refractory dilution. In addition, the slag sampels have fluid fusion temperatures domewhat lower than its parent coal ash, especially those of primary-zone slag, indicating the slag contains more homogeneous fluid parts of coal ash.

Candle dust collected after IBSTF No, 9 duration test was also analyzed for its composition and particle size distribution. The candle dust sample was collected from the secondary filter vessel after the run which used the dolomite sorbent injection. The sample consists mainly of spent sorbent with small amount of fly ash (coal particulate) escaped from PRIS. The particle sizes of dust were found to be essentially minus 65 mesh $(212 \mu \mathrm{m})$ compared to 50 mesh $(297 \mu \mathrm{m})$ of the original dolomite sorbent $(D-100)$ as analyzed in Table 19. The particles median size was

Table 19. Particle Slze Distribution of Candle Dust and Dolomite Sorbent

\begin{tabular}{|ccc||}
\hline & \multicolumn{2}{c|}{ Cumulative Welght (Passing \%) } \\
\cline { 2 - 3 } Particle Size $(\mu \mathrm{m})$ & Candle Dust & Dolomite D-100 \\
\hline 297 & -- & 99.3 \\
212 & 98.3 & -- \\
150 & 97.6 & 86.8 \\
106 & 95.9 & 70.0 \\
75 & 92.9 & 55.3 \\
54 & 86.2 & 35.5 \\
45 & 85.9 & 28.4 \\
38 & 77.5 & 23.2 \\
30 & 75.7 & 19.5 \\
20 & 58.2 & 12.2 \\
15 & 35.3 & 8.4 \\
10 & 14.0 & 4.8 \\
8 & 7.8 & 3.3 \\
6 & 4.3 & 1.7 \\
4 & 1.0 & 1.3 \\
2 & 0.4 & 0.9 \\
Median Size $(\mu \mathrm{m})$ & 17.0 & 72.0 \\
\hline & & \\
\hline
\end{tabular}


dropped from $72 \mu \mathrm{m}$ of the original sorbent to $17 \mu \mathrm{m}$ in the candle dust. The D-100 dolomite has $4.8 \%$ passing through $10 \mu \mathrm{m}$ while the dust sample contains $14.0 \%$ finer than $10 \mu \mathrm{m}$. The composition analyses of candle dust (along with the dolomite sorbents) are listed in Table 20. As observed, a significant amount of alkali ( $\mathrm{Na}_{2} \mathrm{O}$ and $\mathrm{K}_{2} \mathrm{O}$ ) was accumulated in the dust sample. This indicates spent sorbent acting as an alkall capture because the original dolomite sorbents contain only a trace of alkall. The X-ray analysis showed that the dust was primarily anhydrous calcium sulfate ( $\mathrm{CaSO}_{4}$ ) and a moderate amount of magnesium oxide ( $\left.\mathrm{MgO}\right)$.

Table 20. Composition Analyses of Candle Dust and Sorbent

\begin{tabular}{|c|c|c|c|c|}
\hline Compoalton, $\%$ & $\begin{array}{c}\text { Candlo } \\
\text { Dust }\end{array}$ & $\begin{array}{l}\text { Dolomito } \\
\text { D-303 }\end{array}$ & $\begin{array}{c}\text { Dolomite } \\
\text { D-100 }\end{array}$ & $\begin{array}{l}\text { Hydratod } \\
\text { Lmm }\end{array}$ \\
\hline $\mathrm{SlO}_{2}$ & 5.04 & 0.65 & & \\
\hline $\mathrm{Al}_{2} \mathrm{O}_{3}$ & 2.82 & 0.05 & & \\
\hline $\mathrm{TiO}_{2}$ & 0.11 & $<0.01$ & & \\
\hline $\mathrm{Fe}_{2} \mathrm{O}_{3}$ & 1.59 & 0.12 & & \\
\hline $\mathrm{CaO}$ & 31.02 & 29.80 & & \\
\hline MgO & 20.06 & 18.90 & & \\
\hline Sro & 0.06 & $<0.01$ & & \\
\hline $\mathrm{Na}_{2} \mathrm{O}$ & 0.404 & $<0.001$ & $<0.001$ & 0.010 \\
\hline $\mathrm{K}_{2} \mathrm{O}$ & 0.184 & $<0.001$ & 0.002 & 0.028 \\
\hline $\mathrm{P}_{2} \mathrm{O}_{3}$ & 0.05 & 0.08 & & \\
\hline $\mathrm{MnO}_{2}$ & 0.06 & 0.03 & & \\
\hline $\mathrm{PbO}$ & $<0.01$ & $<0.01$ & & \\
\hline $\mathrm{Cr}_{2} \mathrm{O}_{3}$ & 0.10 & $<0.01$ & & \\
\hline NiO & 0.07 & $<0.01$ & & \\
\hline $\mathrm{V}_{2} \mathrm{O}_{3}$ & 0.017 & $<0.01$ & & \\
\hline $\mathrm{SO}_{3}$ & 44.5 & 0.004 & & \\
\hline $\mathrm{CO}_{2}$ & 0.57 & 47.1 & & \\
\hline $\begin{array}{l}\text { X-ray Diffraction } \\
\text { Dolomite } \\
\text { Calctte } \\
\text { Calctum Sulfate } \\
\text { Magnesium Oxide }\end{array}$ & $\begin{array}{c}\text { - } \\
\text { Predominant } \\
\text { Moderate }\end{array}$ & $\begin{array}{c}\text { Predominant } \\
\text { Trace } \\
- \\
-\end{array}$ & & \\
\hline
\end{tabular}


A section of the silicon-carbide rod inserted for the PRIS (from IBSTF No. 9 run) was examined to determine any correlation or key elements of slurny fuel which could cause the facts of PRIS rod erosion and deposition. The worn area of PRIS rod was studied for signs of possible attack by the fuel iron and/or alkall vapor present in the hot gas.

The results of laboratory photograph analysis of the PRIS silicon carbide rod showed numerous metallic spheres in the slag and several large metallic globs $(0.2-0.4 \mathrm{~mm})$ at the silicon carbonslag interiace. It also showed wherever a metallic glob was observed in contact with the silicon carbide there was an obvious reaction resulting in corrosion of the sillicon carbide. The various phases present in the cross section were analyzed in a scanning electron microscopy using energy dispersive spectroscopy (EDS). It was found that the metallic particles consisted of roughly $70 \%$ iron and $30 \%$ silicon. No foreign elements like sodium were present in the SiC tube within detection limits.

Sillcon carbide is highly resistant to most substances at high temperature but is readily attacked and dissolved by liquid ferrous metals. The iron present in the slag was therefore responsible for the attack of PRIS rods. Controlling iron content in slurry fuels or replacing the PRIS-rod silicon carbide by another material, such as alumina, aluminum nitride, or boron nitride, is recommended.

\section{Slag/Ash Waste Dlsposal}

The EPA Toxicity Characteristic Leaching Procedure (TCLP) was applied to a minus 35 mesh split of a slag sample to determine the leachable metal toxicity for slag disposal. The slag sample was obtained from the primary zone after burning S-1 slumy in Run \#48 of TSSC testing. The applled TCLP is the latest official method published in the March 29, 1990 Federal Register (Vol. 55, No. 61) by National Safety Councll. The test results are shown in Table 21. As observed, the concentration of each of the regulated metals in the slag leaching solution was well less than the allowable level specified by the EPA. In other words, it does not appear that this slag sample would be classified as a hazardous waste. Usually, a waste is classified as a toxicity characteristic waste if chemicals listed are at, or above, the specified regulatory levels. In that case the material will be subject to all RCRA (Resource Conservation and Recovery Act) hazardous waste requirements.

The candle dust was also subjected for EPA leachability study to determine any leachable metal toxicity (Table 21). As shown, the extract concentrations of heavy metals were weil below the published EPA regulatory levels, except for mercury. It is believed that the high mercury value was attributed to the mercury background interference from high sulfur and/or calcium in the spent sorbent. The above results of EPA testing will help to design disposal strategies for the combustor waste products.

A water sample taken from the water-quenched slag pit and a sample of the source water were determined to find which elements leached from the slag during quenching. The concentrations of elements of particular interest which were found in these two water samples are given in Table 22. A concentration of calcium, $79 \mathrm{ppm}$, was measured in the slag pit water compared to $58 \mathrm{ppm}$ in the original source water; while sulfur was $55 \mathrm{ppm}$ in slag pit versus $53 \mathrm{ppm}$ in the source water. It does not appear that any of the listed elements leached from the slag to any significant extent during the slag quenching operation. 
Table 21. Leachablity Measurement of Slag and Candle Dust

\begin{tabular}{|c|c|c|c|c|}
\hline Conotituent & $\begin{array}{l}\text { Slag Extract } \\
\text { (ppm) }\end{array}$ & $\begin{array}{l}\text { Candle Dust } \\
\text { Extract (ppm) }\end{array}$ & EPA HW NO." & $\begin{array}{l}\text { EPA Regulatory } \\
\text { Level (ppm) }\end{array}$ \\
\hline Aluminum & $<0.01$ & $<0.02$ & & \\
\hline Arsenic & - & $<0.02$ & D004 & 5.0 \\
\hline Bartum & 0.4 & 0.11 & D005 & 100.0 \\
\hline Beryllium & - & $<0.05$ & & \\
\hline Boron & - & 0.14 & & \\
\hline Calcium & - & $>2800$ & & \\
\hline Cadmium & $<0.005$ & 0.006 & D006 & 1.0 \\
\hline Chromium & 0.006 & 0.32 & Doo7 & 5.0 \\
\hline Cobalt & - & $<0.01$ & & \\
\hline Copper & $<0.005$ & $<0.005$ & & \\
\hline Iron & - & $<0.005$ & & \\
\hline Lead & $<0.05$ & 0.08 & D008 & 5.0 \\
\hline Magnesium & - & 960 & & \\
\hline Manganese & - & $<0.001$ & & \\
\hline Mercury & $<0.01$ & $<0.5$ & Do09 & 0.2 \\
\hline Molybdenum & -- & 0.56 & & \\
\hline Nickel & $<0.01$ & $<0.01$ & & \\
\hline Solenium & $<0.01$ & $<0.01$ & D010 & 1.0 \\
\hline Silver & $<0.01$ & $<0.01$ & D011 & 5.0 \\
\hline Sulfur & - & 900 & & \\
\hline Tungsten & - & 0.08 & & \\
\hline Vanadium & 0.07 & $<0.01$ & & \\
\hline Zinc & $<0.005$ & 0.0085 & & \\
\hline
\end{tabular}


Table 22. Slag-Quench Water Analysis

\begin{tabular}{||lccc||}
\hline & & \multicolumn{2}{c||}{ Concentration, ppm } \\
\cline { 3 - 4 } & Symbol & Source Water & Slag Pit \\
\hline Elements & & & \\
Arsenic & $\mathrm{As}$ & $<0.02$ & $<0.02$ \\
Bartum & $\mathrm{Ba}$ & 0.07 & 0.16 \\
Cadmium & $\mathrm{Cd}$ & $<0.02$ & $<0.02$ \\
Calcium & $\mathrm{Ca}$ & 58 & 79 \\
Chromium & $\mathrm{Cr}$ & $<0.01$ & $<0.01$ \\
Iron & $\mathrm{Fe}$ & 0.005 & 0.005 \\
Lead & $\mathrm{Pb}$ & $<0.1$ & $<0.1$ \\
Mercury & $\mathrm{Hg}$ & $<0.01$ & $<0.01$ \\
Potassium & $\mathrm{K}$ & 5.4 & 4.8 \\
Selenium & $\mathrm{Se}$ & $<0.4$ & $<0.4$ \\
Silver & $\mathrm{Ag}$ & $<0.02$ & $<0.02$ \\
Sodium & $\mathrm{Na}$ & 92 & 90 \\
Sulfur & $\mathrm{S}$ & 53 & 55 \\
Dissolved Solids & & 531 & 597 \\
pit & & 7.05 & 7.78 \\
\hline
\end{tabular}

\subsubsection{Fuel Preparation Tests}

\section{Integrated Fuel Preparation System}

The lease unit of Drais grinding mill and slurrying equipment arrived on site. The Drais Perl Mill is a higher speed version of the stirred ball mill which has been used to grind coal and prepare slurry fuel by AMAX currently and by other coal slurry manufacturers in the past. The purpose of this rental arrangement is to gain the experience for integration of the on-site slurry fuel preparation equipment with the bench scale combustor ings and with the full scale engine testing facillty.

Figure 43 shows the outline drawing of Drais Mill and slurry preparation system. Coal, typically of $1 / 16$ in. $\times 0$ size is pneumatically transported into a hopper by pulling a negative pressure on the hopper and then vacuuming the coal out of the drum container. The coal then is mass flow controlled down the feed hopper. Liquid water and additive (if necessary) are also flow controlled, entering with coal at the mouth of the screw ioeder. Coal and carrier liquid are then transported Into the mill at a controlled rate set by the desired grinding size. As the coal and water are fed into the bottom of the mill they are commingled with the grinding media and under go high shear and Impact grinding as they pass through the mill. The discharge end of the mill is equipped with 


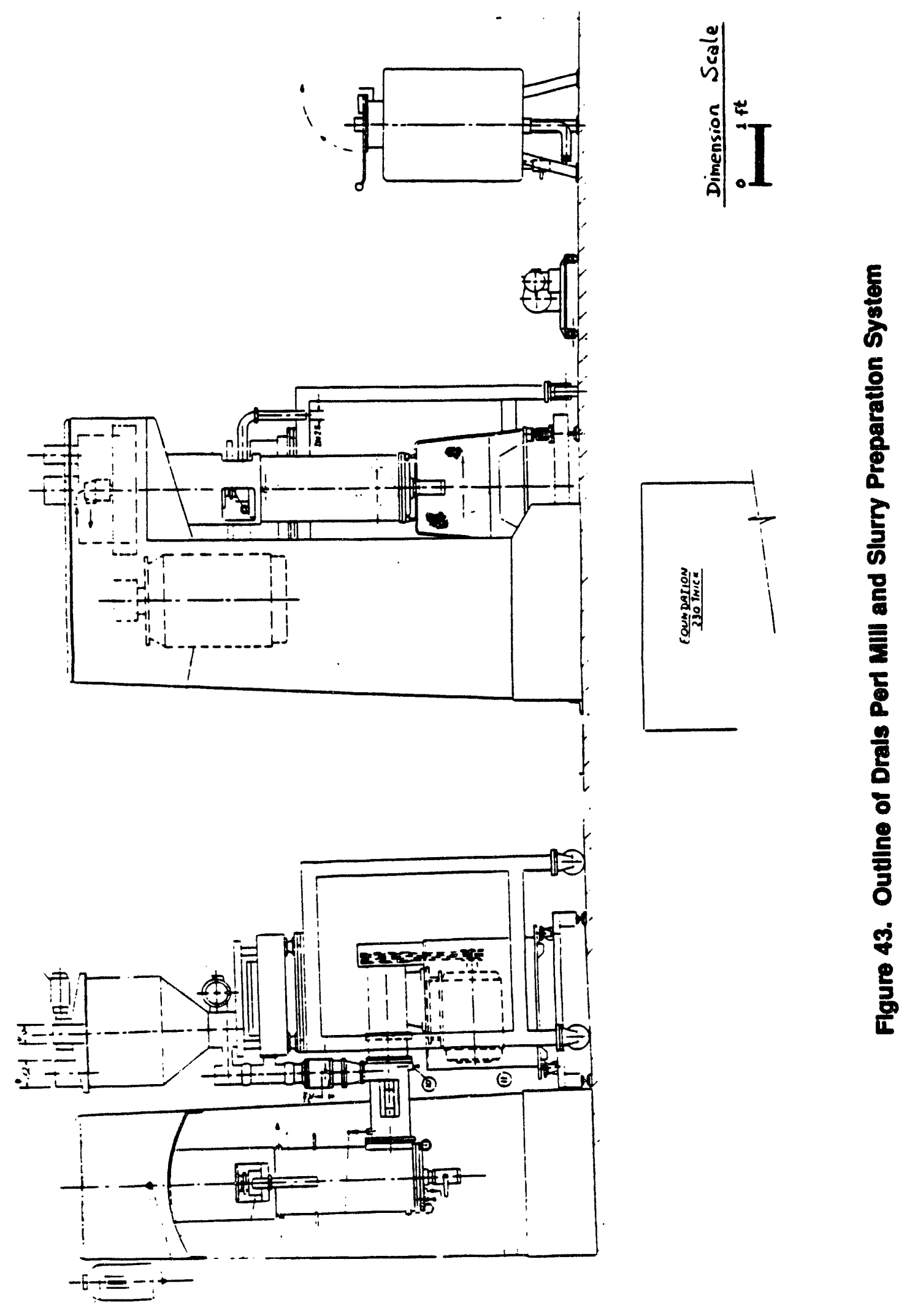


a frictional gap separator, which retains the grinding media while allowing the slurry product to flow out of the discharge nozzle. The process variable such as coal feed rate, liquid feed rate, size and amount of grinding media, rotor speed, separator gap can be controlled proportionally or independently of each other to meet the optimum product requirements.

A total of four tests is scheduled using two different mesh size of coal feedstock. One is boiler grade which has particle size $75 \%$ below 200 mesh and the other has the top size below 16 mesh. A summary of the Tests and goals of each test are listed in Table 23. The key measurements of slumy outputs will include the product particle size distribution, production rate, and slumy viscosity and stability. The final test will demonstrate to burn the fresh slumy prepared on site at the bench-scale combustor ig.

\section{Table 23. On-Site Grinding and Slurry Preparation}

\begin{tabular}{|c|c|c|}
\hline & Tost Goal & Coal Used \\
\hline Test 1: & Shakdown/Grinding Mill Installation & 1 drum \\
\hline Test 2: & $\begin{array}{l}\text { Initial Grinding Mill Operation } \\
\text { - Measure particle size distribution }\end{array}$ & $\begin{array}{l}1 \text { drum boiler grade coal } \\
1 \text { drum } 16 \text { mesh coal }\end{array}$ \\
\hline Test 3: & $\begin{array}{l}\text { Operate Grinding Mill } \\
\text { - Measure slumy production rate } \\
\text { - Measure slumy stability } \\
\text { - Produce batch slurry and test at TSSC }\end{array}$ & 4 drums \\
\hline \multirow[t]{2}{*}{ Test 4: } & Produce On-Site Slurry & 3 drums \\
\hline & & $\Sigma 10$ drums \\
\hline
\end{tabular}

The proposed full-size slurry fuel preparation will be processed first via a two-stage coal particle size reduction. The purchased coal will be received in size ranges about 2 -inch $\times 0$. It requires a crushing stage to reduce the size to about 16 mesh before feeding into a wet grinding (i.e., Drais Mili) for slumy preparation. Types of crusher are being evaluated so that the sultable capacity equipment could be used in the slurry preparation for the full-scale proof of concept 100 . hr engine test. For our application of reducing 2 in. $\times 0$ coal to a 16 mesh product with 5-7\% surface moisture at a rate of approximately $2.5 \mathrm{ton} / \mathrm{hr}$, a hammer mill with a $25 \mathrm{HP}, 1800$ RPM motor, V-belt drive and guard-mounted on a steel subbased was identified. Price quotes for crushing equipment have been requested from Buffalo Hammer Mill (Buffalo, NY) and American Pulverizer Company (St. Louis, MO). Tumbling mills (l.e., rod, ball mills) and other crushing equipment for the coarse size reduction are also being evaluated.

Preliminary analyses indicate that slurry produced by on-site Drais Mill has stable properties without forming any hard park on the bottom of drum after 2 weeks before combustion. The slumy was formulated without adding the stabilizer. The viscosities were measured between 200 $450 \mathrm{cp} @ 100$ sec $^{-1}$ and $250-400 \mathrm{cp} @ 1000$ sec $^{-1}$. The solid loadings of preliminary tests were determined in the ranges of 48.8 to 50.7 wt\% when the coal and water ratio was set at 50:50 at 
the grinding mill. The particle size distribution of slumy is under measurement by size screening In conjunction with a particle settling velocity analyzer (Sedigraph method) and by a Microtrac laser light-scattering particle size analyzer.

Equipment costs, and probable operating costs, for systems capable of handling 2.0 to 2.5 tons per hour llinois coal to produce 1000 gallons per hour of slumy for the full-scale engine testing, are estimated as the following:

\section{Grinding MIII}

\section{Specheations:}

Feeding Rate

Grinding chamber capacity

$9,720 \mathrm{lb} / \mathrm{hr}$

972 gallons/hr

66 gallons

Costs with Integrated Grinding Mill and Slurrying

Preparation System:

Grinding mill

$\$ 850,000$

Crusher/Conveyor

Support equipment \& installation

10,000

Coal cost @ \$25/ton

100,000

6,250

Coal transportation cost (@ \$20/ton for llinois coal)

Labor (manpower @ \$50/hr)

5,000

Utillties

2,500

$\Sigma \$ 978,750$

Others (@ 10\%)

97,875

Total

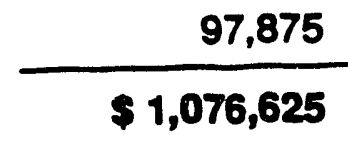

The above estimation is made for the wet grinding via Drais mill when producing about 100,000 gallons of minus $45 \mu \mathrm{m}$ shurry fuel on-site for 100-hr full-scale engine testing. Assuming an average distance of 100 miles per trip, the freight charges will be $\$ 20.00$ per ton of coal. A coal pile area $2400 \mathrm{ft}^{2}$ with the base of about $60 \mathrm{ft}$. $\times 40 \mathrm{ft}$. will be required for the incoming coal storage. A conveyor will be used to transport coal into the crusher before the fine grinding. Online production can minimize the storage of finished fuel and the tanker trusks required.

In the case of purchasing fuel from slumy manufacturing company, the 100-hr testing (100,000 gallons) would cost about $\$ 1,014,200$ based on the price of slurry at $\$ 8.00$ per gallon as estimated below: 


\section{Costs with Purchasing Fuel:}

\author{
Fuel Cost (@ \$8.00/gallon) \\ Transportation Costs \\ (to storage tanks and test site) \\ Storage Tank Costs/Installation \\ Labor and Utilities
}

Others (@10\%)

Total

$$
\begin{array}{rr}
\$ & 800,000 \\
\$ & 70,000 \\
\$ & 50,000 \\
\$ & 2,000
\end{array}
$$

$\Sigma \$ \begin{array}{r}922,000 \\ 92,200\end{array}$

$\$ 1,014,200$

With purchasing the slumy from manufacturers, a huge or several slurry storage tanks near the engine test site with a total capacity of more than 100,000 gallons will be required. In addition, a total about 23 tanker truck loads would be needed to transport the finished slumy from the manufacturing site to the storage tanks. If the storage tanks do not locate nearby the test site, then the slurry will still need to be transported by tanker trucks to the combustor fuel system for the 100-hr engine testing.

\section{Fuel Preparation - Initial and Finish Grinding}

The laboratory task of initial and finish grinding was completed at AMAX R\&D. The test data were analyzed and its results were used to develop the design and operating criteria for slurry fuel preparation, and to provide process cost information for the fuel cost projection spreadsheet.

In the initial grinding, it was found that changing either the loading or the viscosity had little effect upon grinding performance as long as the slurny was fluid (viscosity less than about 1,000 centipoise). The important fuel specification which impact the design and operation of the initial grinding circuits are the particle size distribution and the coal grindability. The test results of ball mill and rod mill followed the Bond equation as

$$
W=W_{1}\left\{\left[\frac{100}{P(80)}\right]^{0.5}-\left[\frac{100}{F(80)}\right]^{0.6}\right\}
$$

where $W$ is the energy applied in $k W h$ per short ton and $W_{1}$ is the "work index", a proportionality constant, specific for the material being ground. $P(80)$ and $F(80)$ are taken from the cumulative particle size distribution curves for the product and feed, respectively. The work index $\left(W_{1}\right)$ for coal can be expressed by the Hardgrove grindability Index (HGI),

$$
W_{i}=\frac{435}{H G 1^{0.91}}
$$


Taken together, Equations 1 and 2 suggest that the capacity of a grinding circuit with a fixed amount of installed power should almost directly proportional to the HGI of the coal for the initial wot grinding operation.

In the finish grinding, stirred ball mills seem to be particularty effective for this type of grinding. Table 24 lists the source coals and the ranges of the operating variables investigated during the finish grinding tests. The test results of finish grinding by using a 40-liter Draiswerke stirred ball mill fitted well with the correlated Bond equation. The following equation predicts the amount of energy (W) required for grinding in a stirred ball mill in kWh per dry short ton of coal,

$$
W=\frac{421.9}{H G 1^{0.00}}\left[\left[\frac{100}{P(M M D)}-\right]^{0.07}-\left[\frac{100}{F(M M D)}\right]^{0.07}\right] f_{\text {bet }}
$$

where $P(M M D)$ and $F(M M D)$ are the mass mean diameters of the product and feed particle size distributions, respectively. HGI is the Hardgrove grinding index of the coal and $f_{b u}$ is the grinding media size efficlency factor. The ball size efficiency factor of grinding media is function of the mass mean diameter of the ball size and the mass mean diameters of the feed and product size distributions of the coal. The equation (Eq. 3) indicates that the feed grinding energy required is governed by the grindability of the coal and by the size of the grinding balls used in the mill.

Figures 44 and 45 show the relattve effects of variations in the finished particle size specification and changes in the grindabillty of the coal on grinding capacity. The relative grinding capacity of the stirred ball mill increases with increasing the top size of product slumy. Similarty, the grinding capactiy increases in a linear relationship as the Hardgrove grindability index of the coal increases. (The HGl of common coals are typlcally around 55 or 60 but can range between 40 and 100 with the higher index number denoting a more easily ground materials.) On the other hand, it appears that variations in solids loading, slumy viscosity, and dispersant addition do not have any significant effect upon the grinding performance of the stirred ball mill when operating within the normal range of conditions.

In general, the finish grinding step is more significant operation than the initial grinding step in terms of both capltal costs and operating costs. Stirred ball mills used in the finish grinding are available in a number of configurations and from a number of manufacturers. Draiswerke advertises a 1,500-ifter model which draws 2,000 horsepower that is believe to be the largest unit commercially available. Such a unit would have a capactty of about 20 tons of coal per hour in a typical micronized slumy fuel application. Multiple units are thus required to provide the capacity for the proposed multiple installations.

\section{Full-Scale Tosting Fuel}

The first bulk lot ( 4500 gallons) of slumy prepared by AMAX R\&D has been shipped to Peoria for the full-scale combustor testing. The slumy was delivered by a tanker truck and unloaded in an on-site fuel tank which has a capacity of about 6000 gallons and is equipped with an agitator. Figure 46 illustrates the fuel system of full scale combustor test facility. During the testing, slumy 


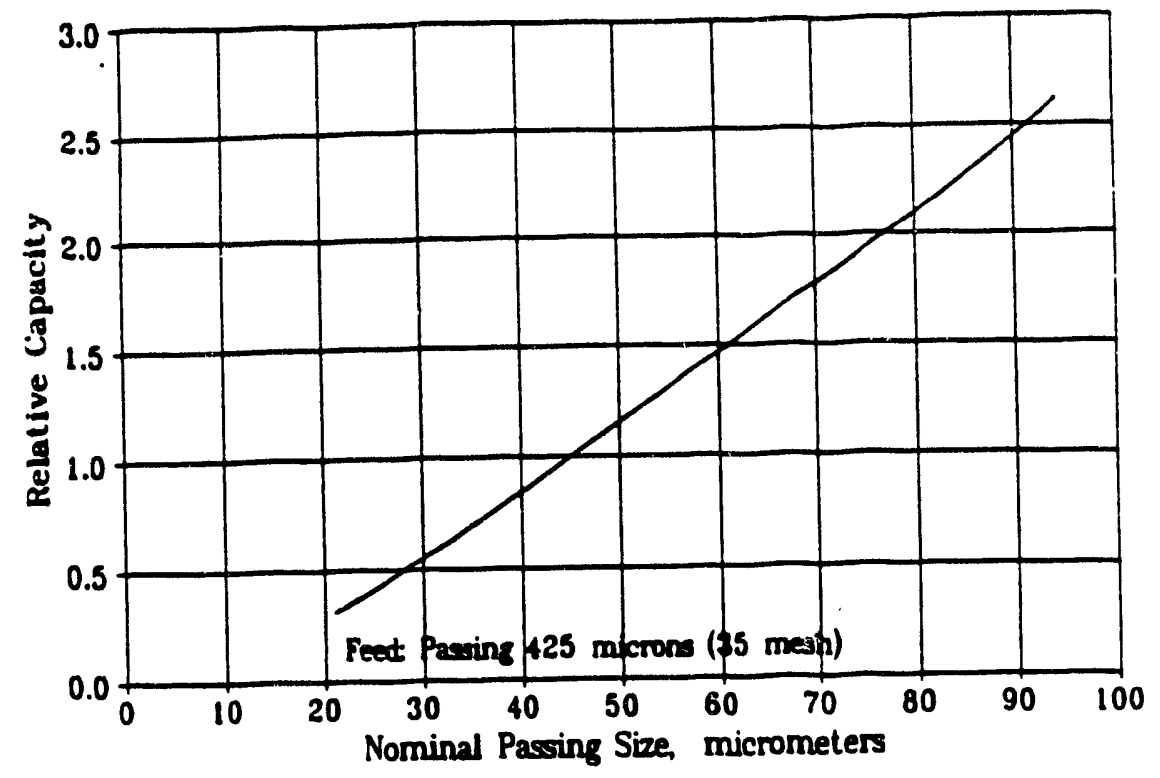

Figure 44. Relative Capacity of Stirred Ball Mill Versus Nominal Top Slze of Product Slumy. (Relative capacity $=1.0$ when producing $-45 \mu \mathrm{m}$ slurry from $-425 \mu \mathrm{m}$ feed slumy)

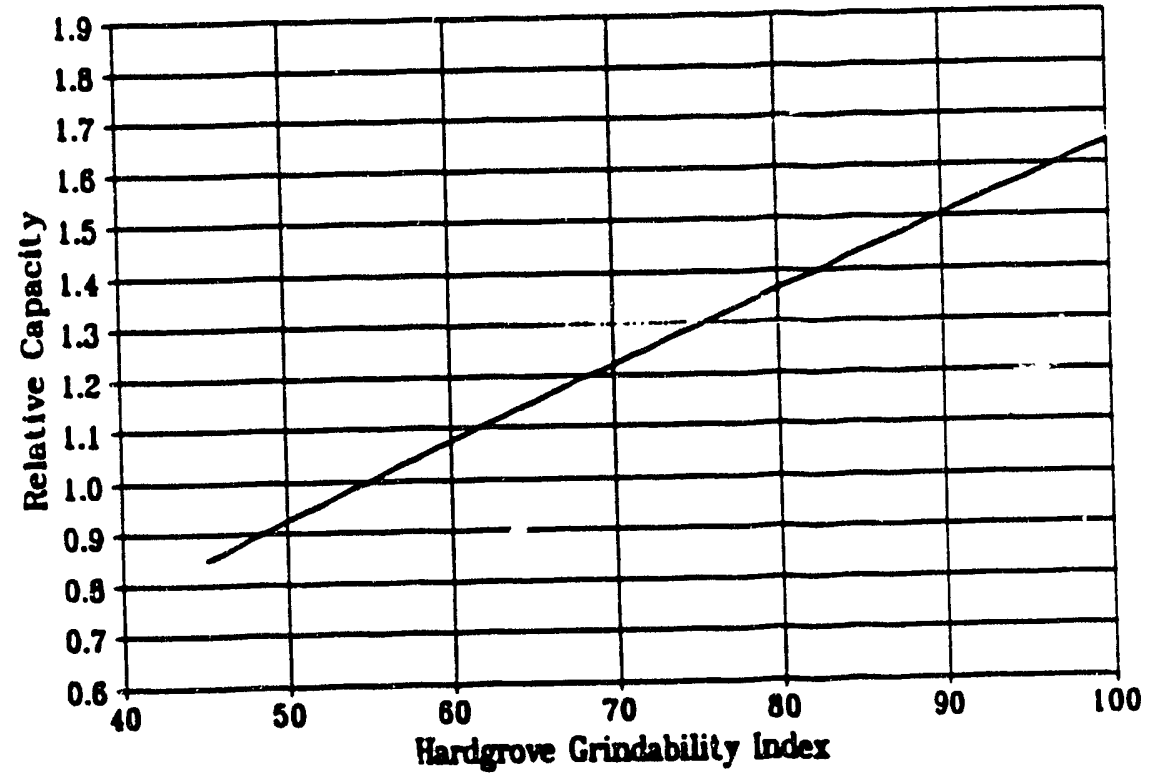

Flgure 45. Relative Capaclty of Stirred Ball Mill Versus Hardgrove Grindablilty Index of Feed Coal. (Relative capaclty - 1.0 when grinding coal with Hardgrove grindability index of 55) 


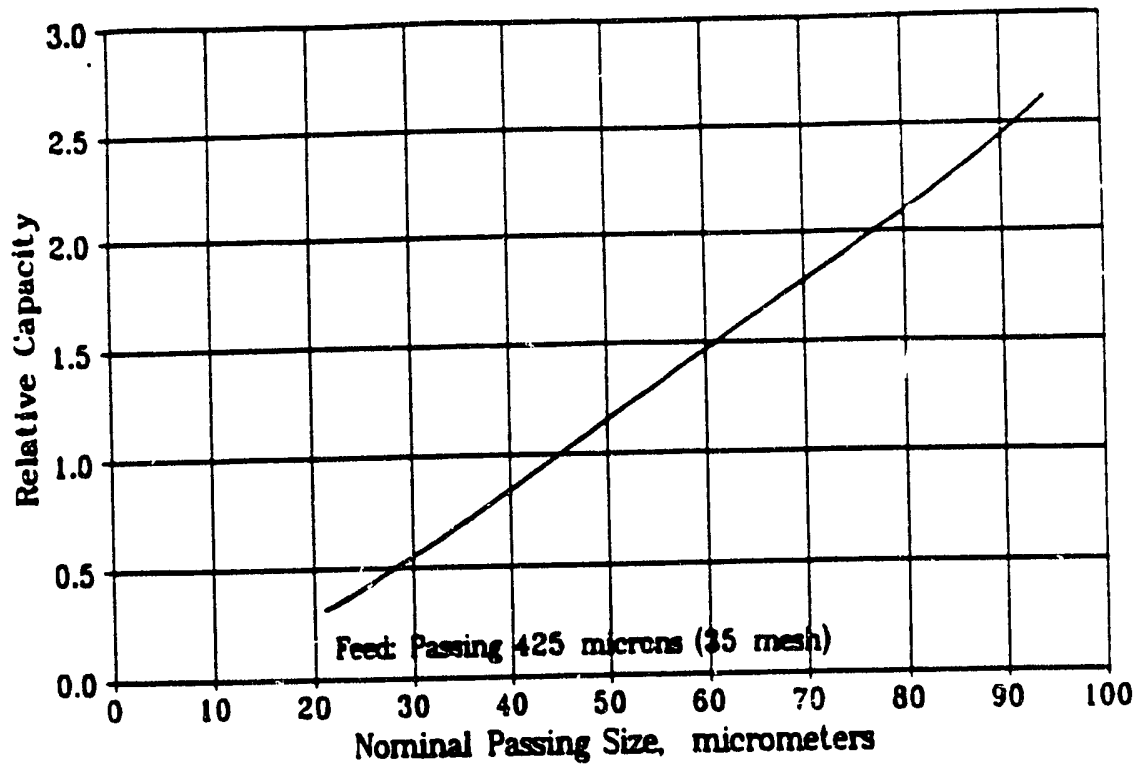

Figure 44. Relative Capacity of Stirrod Ball MIII Versus Nominal Top Size of Product Slumy. (Relative capacity $=1.0$ when producing $-45 \mu \mathrm{m}$ slurry from $-425 \mu \mathrm{m}$ feed slurry)

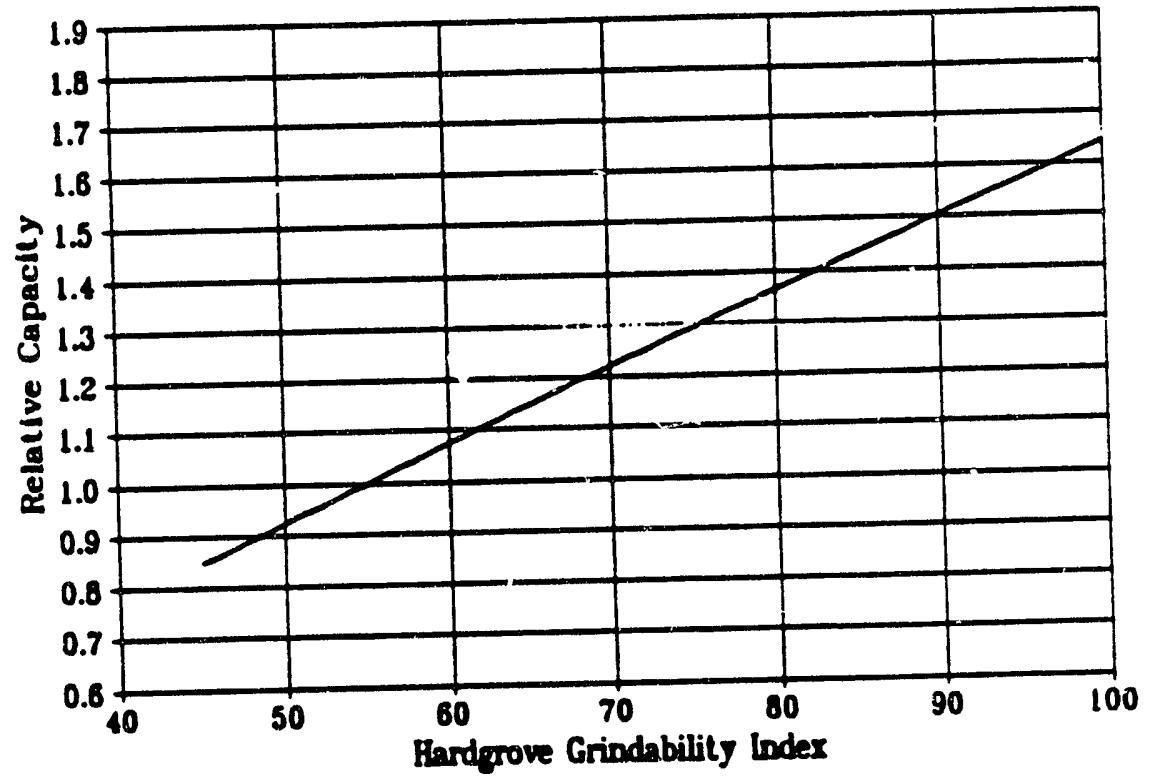

Figure 45. Relative Capacity of Stirred Ball Mill Vorsus Hardgrove Grindability Index of Feed Coal. (Relative capaclty - 1.0 when grinding coal with Hardgrove grindability index of 55) 


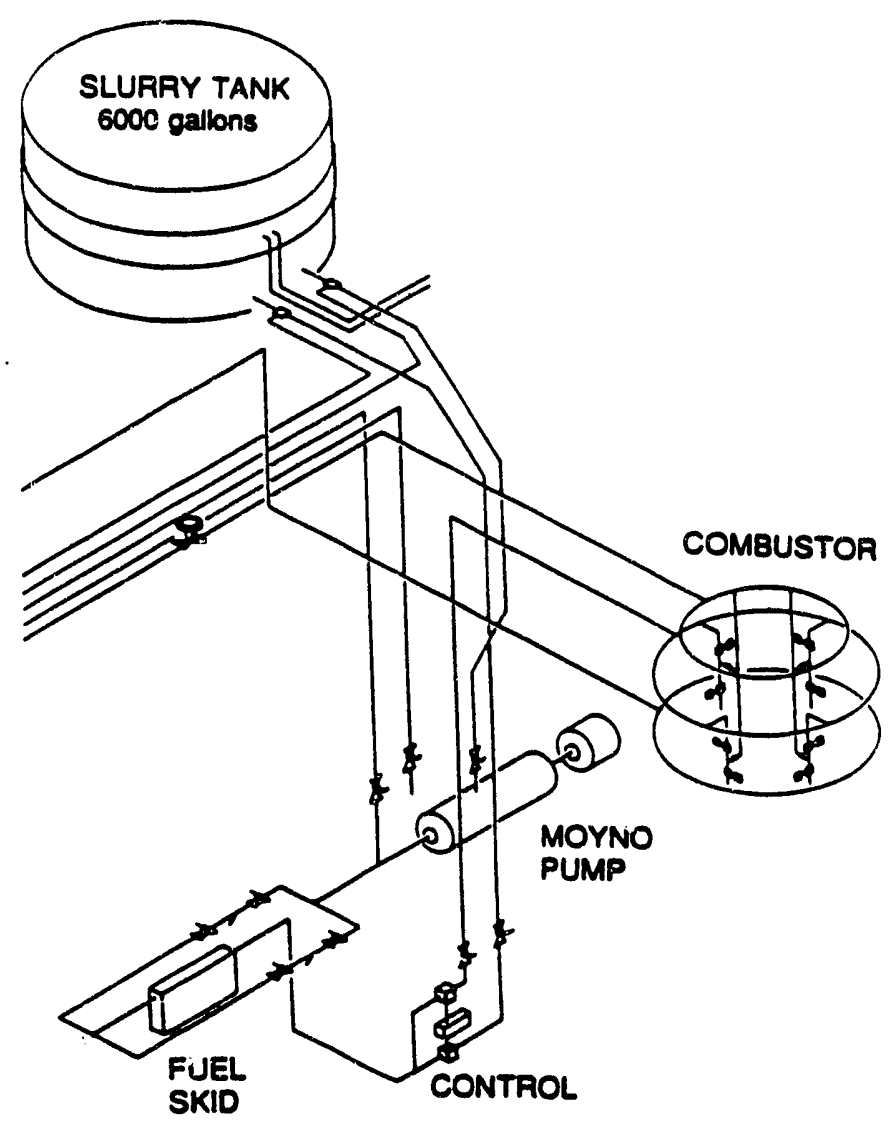

Flgure 46. Full-Size Combustor Tests: Fuel System

Concerns on the slurry fuel and flushing wastes handling during the full-size combustor testing are summarized:

\section{Slumy Flushing Waste}

The flushing liquids from fuel lines contain waste wash water and coal slumy. The coal particles in the llquids are dispersing well and not easily settling-down. Our past experience showed a flocculation agent is needed to be added to stimulate the solld-liquid separation before clean water can be discharged.

The flocculation procedures begin with adding dry alum or liquid alum, at 5.5 wt\% on coal basis, to the waste slurry and stir well, allowing the waste slurry mixture settledown, and then decanting the clear supernatant water. The alum can be either the ammonium aluminum sulfate double salt or the straight aluminum sulfate. Alum forms aluminum hydroxide flocs in weakly acid and neutral water. These flocs are effective for coagulating the coal and precipitating the dispersant in the slumy. The followings show an example to treat $\mathbf{2 0}$ gallons of slurry waste with adding alum as a flocculation agent. 
- For $\mathbf{2 0}$ gallons slurry waste through the fuel lines,

Total slurry weight $=20$ gallons $\times 10.01 \mathrm{lb} /$ gallon $=200.2 \mathrm{lb}$

Total coal content $=200.2 \mathrm{lb}$ slumy $\times 54.1 \%$ coal loading $=108.3 \mathrm{lb}$

Alum required $=108.3 \mathrm{lb}$ coal $\times 5.5 \%$ alum concentration $=5.96 \mathrm{lb}$

- Dissolve this $5.96 \mathrm{lb}$ of alum in 4 gallons of water before adding into the waste water tank.

This is equivalent to 18 wt\% solution in liquld alum form.

- Allow the waste slurry to settle for 24 hours and decant off the clear supernatant water. Remove the supernatant water from the tank by pumping the water down to just above the sludge line. The remaining sludge contains about 15 to $20 \%$ solids ( 1.5 to $1.8 \mathrm{lb}$ coal per gallon).

- If needed, portland cement can be used to solidify the thickened sludge for the waste landfill.

\section{Make-Up Water}

Water evaporation from the slumy fuel could cause increases of coal loading and slurry viscosity. From a 6,000 to 7,000 gallon tank with $10 \mathrm{ft}$ ID, an evaporation rate of 0.1 inch/day has been measured (based on the AMAX experience in the past). In our feed tank with a closed cover on the top, we do not expect a rate as great as that. However if slurry has to be store $J$ for more than two weeks, the level of slumy fuel in the storage tank should be monitored periodically once a week with a long rod. When the slurry level loses more than a half inch ( $0.5 \mathrm{in}$.), a make-up water (24.5 gallons) needs to be added to keep the constant fuel properties.

Make-up Water $=\pi \times 5^{2} \times 0.5 / 12=3.27 \mathrm{t}^{3}=24.5$ gallons

\section{Slumy Reclrculation}

Upon the completion of a combustion run, the stumy lines are flushed with water wherever possible when shutting down the fuel system. In the case when slumy has to be stored for a long perlod of time (e.g., more than 2 weeks), then besides the low-speed agitation, pumping the slurry through the feed lines and recycling back to the tuel tanks are recommended. This can be carried out once a week for a period of one hour and the recirculation slumy lines do not need water flushing everytime.

\section{Bottom Hard-Pack Cake}

Under certain circumstances of tank agitator or recirculation fallures, a hard pack of slumv could be bullt on the bottom of slurry tank. Also, depending upon each testing, a heel of slurry may be left in the bottom of the tank at the end of a campaign. This remaining slumy may be below the level of the agitator or the tank outlet to the recycle pump. A hard-pack cake could be developed and sometime difficult to be resuspended. If these happen, it is necessary to break up the bottom 
hard-pack by forcing the compressed air into the cake through a long rod-tubing to promote mixing and stir up the content.

\section{Agltator Solection}

Property designed agitators is needed to prolong the on-site storage time without coal particle settlement occurring. To prevent any detrimental effects on the coal-water slumy due to agitation, It is necessary to select an agltator that is highly efficient and imposes low shear to the fluid. Agltator design including motor, impeller, and another storage vessel variable, is directly dependent upon the rheological properties of the stored material, location of the inlet and outlet portals, and tank size. Turbulence in a stirred tank can be correlated with the impeller Reynolds number:

$$
N_{F_{0}}=\frac{A D^{2} N \rho_{1}}{\mu}
$$

where $A=$ a constant dependent on agitator equipment; $D=$ impeller diameter, $m ; N=$ rotational speed, rev/sec; $p_{1}=$ fluid density, $\mathrm{kg} / \mathrm{m}^{3} ;$ and $\mu$ = viscosity, $\mathrm{kg} / \mathrm{m}$-sec. When $N_{\mathrm{Ro}}$ exceeds 10,000 , flow is turbulent. Transitional flow occurs for $N_{p_{0}}$ between 10 and 10,000 . If $N_{A 0}$ is less than 10, flow is laminar.

Based on the above consideration, an agitator with a motor size of $5 \mathrm{HP}$ was identified. For a short storage period, a constant mixing will be carried out with an output constant speed about 23 RPM. However when slurry has to be stored for a long period of time, then the slumy would be required only periodic agitation with a speed about 150 RPM. Continuous vigorous agitation, particularly with vortex formation, should be avoided since the reagent balance may be adversely effected and air may become entrained in the slumy. Regular mixing, perhaps continuously by recycle pumping or operating the mixer at a slow speed or else intermittently by operating the mixer once for an hour or two each day under more vigorous conditions is adequate. This should prevent the formation of a hard-pack cake which could be difficult to resuspend.

Some other operating problems of fuel system may be encountered when the future additional loads are received and stored. Perlodically, the slurry in the storage tank should be monitored for sedimentation at least once a weok. An air lance is useful for manually resuspending a stubbom hard-pack cake, but one should avoid routine use of compressed air for mixing the slumy since bubbling air through the slurry, llke intense agitation, could accelerate evaporation of water from the fuel and re-entrain air into the slurity that might change the slurry ineological properties.

\section{Fuel Cost Assessment}

The fuel cost projections are developed in a spreadsheet from the model which intends to calculate the baseline fuel cost for supplying slurry to a coal-fueled Centaur Model $\mathrm{H}$ cogeneration system. The spreadsheet is structured so that the cost effects of altemative operating scenarios may be examined using a common set of assumptions. The model has been calibrated against fuel costs projections made previously for similar type plants from 14.5 to $100 \mathrm{MW}$ of capacity. 
In our previous studies, the location of the fuel manufacturing plant with respect to the source of the coal and to the cogeneration site was found to have a significant effect upon the cost of fuel to the user. This is largely due to the difference in the cost of transporting lump coal as opposed to transporting slumy fuel. However, this difference also has an impact on the type of receiving, storage, and shipping facilties required at each site. The location of the fuel manufacturing also has an impact upon the salability of any middling products from the manufacturing process and the disposal of refuse from the plant. Locating the fuel manufacturing facilty either at the coal mine or at the user's site allows sharing of some management and supporting staff functions which further reduces the cost of fuel production.

The resulting spreadsheet used to project the fuel cost for an on-site fuel preparation to supply shumy for single Centaur $H$ engine is summarized in Table 25. The production cost of fuel in this case is projected at $\mathbf{\$ 5 . 5 3}$ per million Btu. This cost covers any costs that the user incurs to recelve, store and pump the coal slumy fuel to the bumer. Labor, utilities, operating and maintenance supplies, and indirect costs (such as amortization), are also included. As usual, the on-site fuel cost largely depends upon the operating and maintenance costs, on-site indirect cost, and transport cost of feed coal. The ash content and coal loading of the fuel will only slightly impact the total fuel cost.

Table 25. Operating Cost Summary for CWM Fuel Plan at User Site

\begin{tabular}{|c|c|}
\hline Capacity: & $3.8 \mathrm{MW}$ \\
\hline Fuel Specification: & $\begin{array}{l}55 \% \text { Solid } \\
45 \mu \mathrm{m} \text { Top Size } \\
14 \mu \mathrm{m} \text { MMD } \\
7.0 \% \text { Ash (dry basis) } \\
0.8 \% \text { Sulfur (dry basis) }\end{array}$ \\
\hline Coal Price: & \$27iton \\
\hline $\begin{array}{l}\text { Net Coal Cost: } \\
\text { (w/freight) }\end{array}$ & \$1.15/MMBtu (LHV) \\
\hline Operating \& Maintenance: & \$2.44MMBtu (LHV) \\
\hline Indirect \& Amortization: & \$2.52/MMBtu (LHV) \\
\hline Total Fuel Cost: & \$6.11/MMBtu (LHV) \\
\hline
\end{tabular}




\section{PHASE II - TASK 6 - HOT END SIMULATION}

\subsection{SPECIFC ITEMS OF PROGRESS}

- An RA330 shroud was instalied Inside the candle filter vessel to Inhibit blinding of the candle. Corroded parts in hot valves were replaced with acid resistant components. Both modificaitons were made to increase long-term rig reliability.

- Electric heater coils were installed to add supplemental heat prior to material sample section to combat heat loss.

- Two new methods of mounting a candle to a tubesheet were designed and tested. Each incorporated a ceramic gasketing material to provide the gas tight seal.

- A conical primary zone and impactor section were developed and tested.

\subsection{DISCUSSION}

Efforts continued to prepare the Hot End Simulation Rig (HESR) for the Initial 100-250 hour run of the 1000 hour test series. Several modifications were incorporated into the system and tested. A summary of Hot End Rig testing is shown in Table 26. Some of the system modifications include the installation of acid resistant parts in the system's hot valves, and a shield for the candle filter to prevent sticky, ash bulld-up on the candle element at the entrance to the filter vessel. Also, several candle mount modifications were tested. The addition of supplemental heat was found necessary prior to the material sample section to effectively bring the materials up to test temperature. Most recently, a conical primary zone and impactor section were designed and tested in the rig.

Acid resistant replacement parts for the filter bypass ball valves and the back pressure valve were installed. During earlier testing, in HESR-16, the exhaust temperature was running below the de'N point of sulfuric acid, and was therefore the main contributor of valve deterioration. By reducing the amount of cooling water to the exhaust, and operating with the acid resistant components, the valve corrosion problem was resolved.

During post-test inspection of the rig after HESR-16, it was discovered that the impactor has slagged over and the slag had bult up approximately one inch into the primary zone. Another primary zone was cast and installed. A new impactor section insert, the piece in which the impactor rests, was fabricated. Two inches of Ultracast 90 surrounded the impactor to protect it from corrosion and erosion, and the remaining seven inches were made of Kaolite 2300 to insulate the impactor area and eilhance slag flow.

In evaluating HESR-16, it was concluded that additional heat input was required to economically achieve material sample section temperatures. The Hot End Fig could be operated for an extended period of time to reach target temperatures, but this would not be feasible due to the 
Table 26. Summary of Hot End Simulation Rig Testing

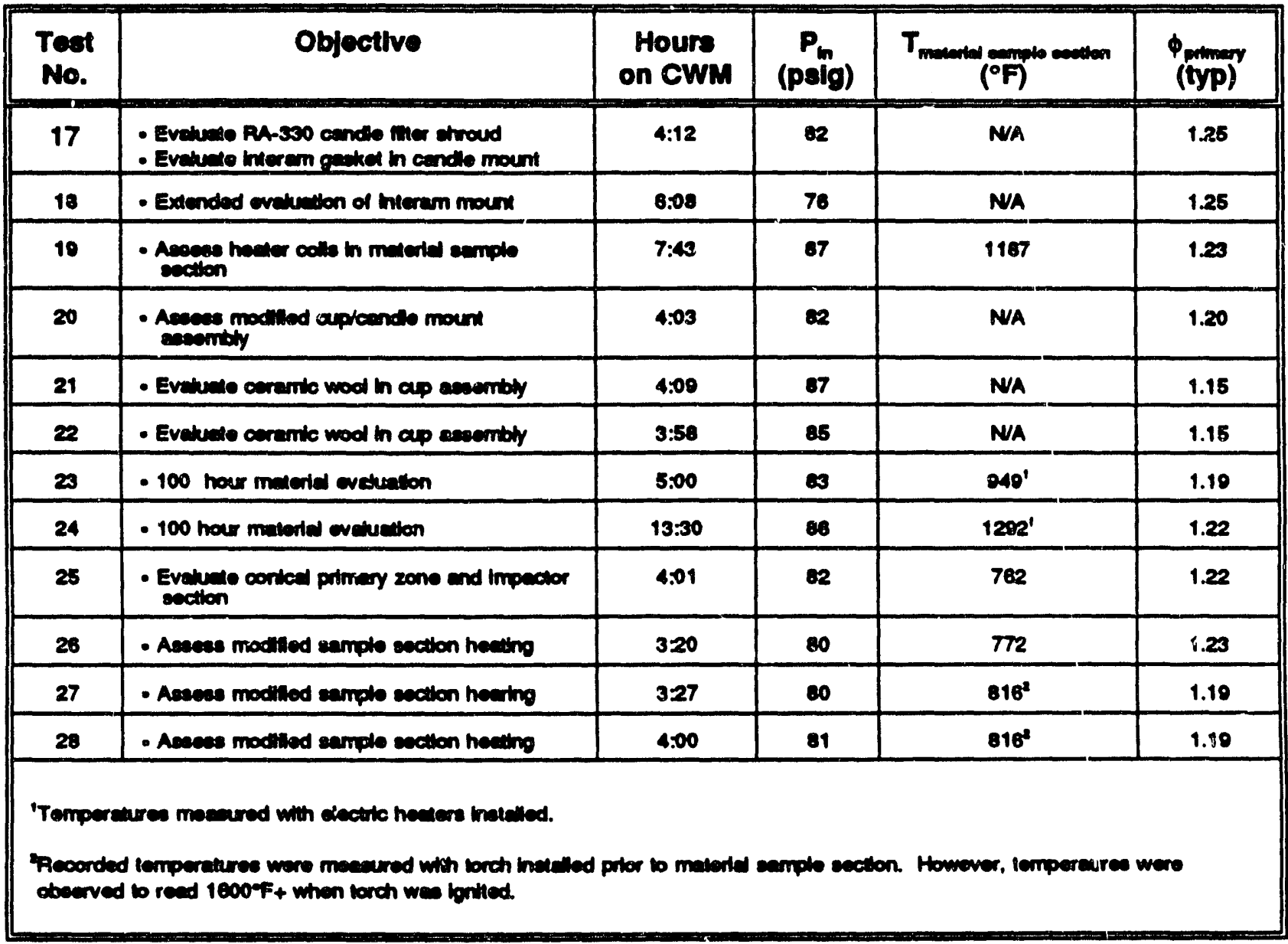

added fuel and manpower expense. Therefore, the use of electric heaters was researched. It was discovered that fow heating elements could withstand the high temperature, alkall-laden, environment. Sillicon carbide heaters were investigated, however, due to the structure of the heaters, they could not be used or modified to use inside a pressure vessel. Therefore, the heater of choice was a flexible, Inconel sheathed heater which could be colled to fit inside the 4 inch duct prior to the sample section. A new spool piece to accomodate the heaters was also designed and fabricated for these electric heaters.

For the candle filter vessel a shroud of RA-330 was fabricated and installed at the Inlet of the vessel, near the extt of the secondary combustion zone. In earlier runs, solids bultt up selectively on the candle at the area closest to the gas inlet. A slag-like material or highly sticky ash formed on the side of the candle that sees the Inlet gas stream, while the back side of the candle appeared clean. The shroud was placed in front of the candle, directly in the flow path, to inhibit candle blinding which was belleved to have occurred during HESR-16, contributing to poor candle performance. 
The test objective of HESR-17 was to test the RA-330 shroud and a new candle mount system using Interam gasketing material. The combustor ran smoothly throughout the run. The short duration of the run combined with the low dust levels made it unnecessary to the purge the candle. The highest differential pressure for the candle was 0.28 psid. In post-test inspection, the candle appeared to have been protected by the shroud from the dust-laden inlet gas. Although the temperature in the filter vessel only reached $1248^{\circ} \mathrm{F}$, the candle mount system appeared effective. The following test would expose the new mount more rigorously.

HESR-18 tested the new candle mount during an extended run at a higher temperature. The combustor ran smoothly throughout the nun, although post-test inspection revealed that slag had accumulated in the primary zone and around the impactor. The candle mount system again appeared to be effective. No dust was observed downstream of the filter vessel.

The material sample section heaters and associated spool piece were received; heaters were instrumented with thermocouples and then coiled to fit inside the four inch duct. An oxidation resistant coating was applled to the heaters to inhibit corrosion/erosion and extend heater life, as the heater sheath is only Inconel.

HESR-19 was run to assess the heater coils. The rig ran very smoothly, with no difficulties encountered, at an equivalence ratio of 1.23 (typ), buming 178 lbs. of CWM. With the electric heaters installed in the duct prior to the sample materials, supplemental ireat was added to boost the gas temperature to $1850^{\circ} \mathrm{F}$. The run began with the heaters setpoint at $1200^{\circ} \mathrm{F}$, which was slowly increased to $1850^{\circ} \mathrm{F}$ over time. About 8.5 hours into the nun, with the setpoint at $1650^{\circ} \mathrm{F}$ for nearty an hour, no change in material temperature occurred, Indicating a malfunction. With temperature and power controllers giving correct readings and signals, the only conclusion was that the heaters had failed. Since the material design temperatures could not be achieved in a reasonable time, a diesel shutdown procedure was initiated. Upon teardown, the rig was Inspected. Most promising was the impactor. It did not slag over, and part of the gap to the slag tap remained open. Although no slag was found in the slag pit, it was dripping down in shapes similar to a stalacttte.

In the material sample section, the Inconel sheath on the heaters was melted at the critical hot/cold junction where the material necks down. It is belleved that the refractory that covers the cold section of the heaters to seal them in the rig also covered the critical junction, creating a hot spot and eventually melting the sheath. Figure 47 shows the heater coil installed in the spool piece. Figure 48 shows the dusting of particulate on the heater after HESR-19. New heaters were ordered and a modifled installation procedure was followed.

Also in the sample section, ash was found. Removal of the candle revealed the places where ash escaped. The filter vessel 'plug', which slides down into the filter vessel and to which the tubesheet and candle are attached, exposed several ash streams around it. The plug did not seal well in the vessel and left a small gap for ash leakby. Ash streams were also found on the candle mount itself. 


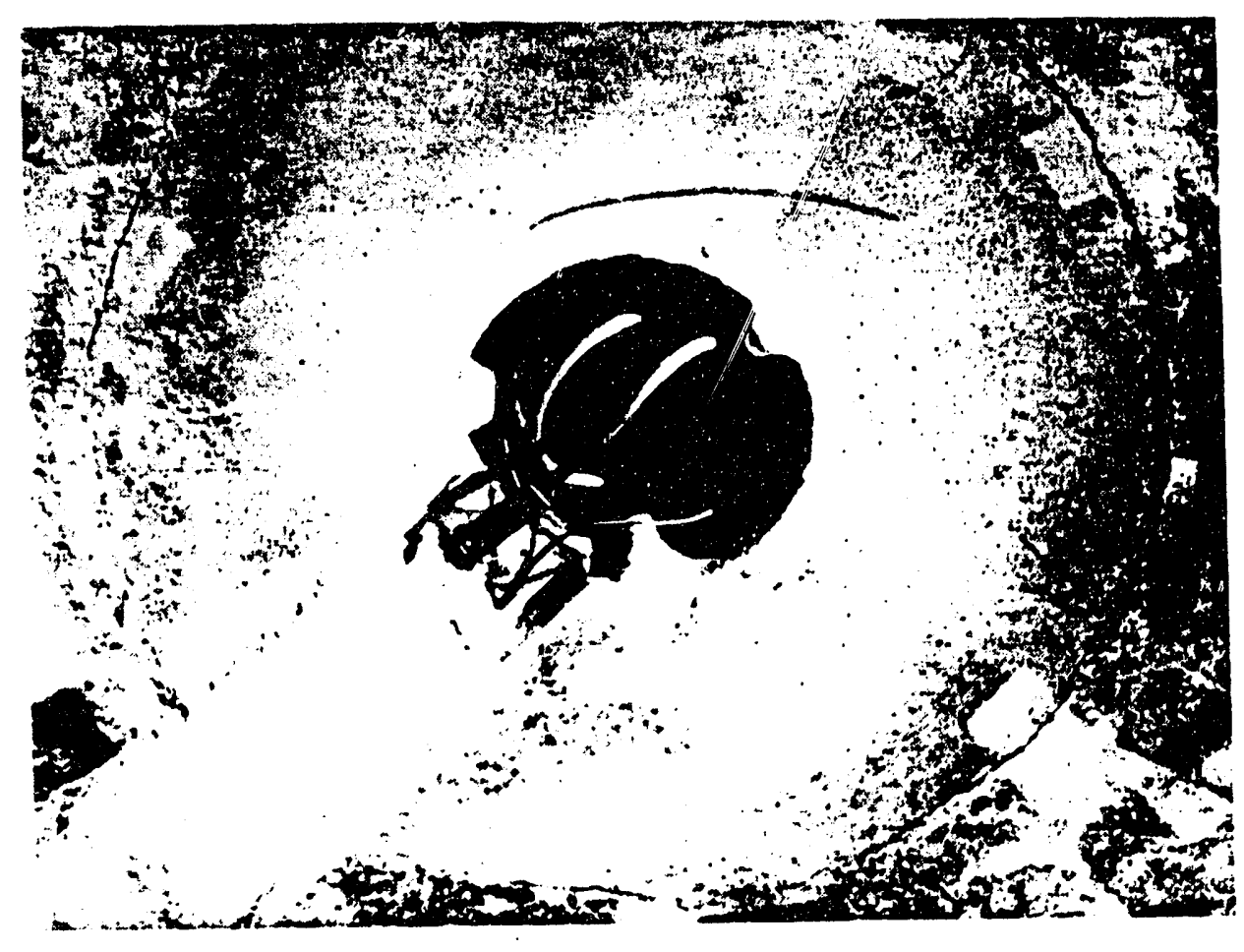

Figuro 47. Heater Coll Prior to Materlal Samples

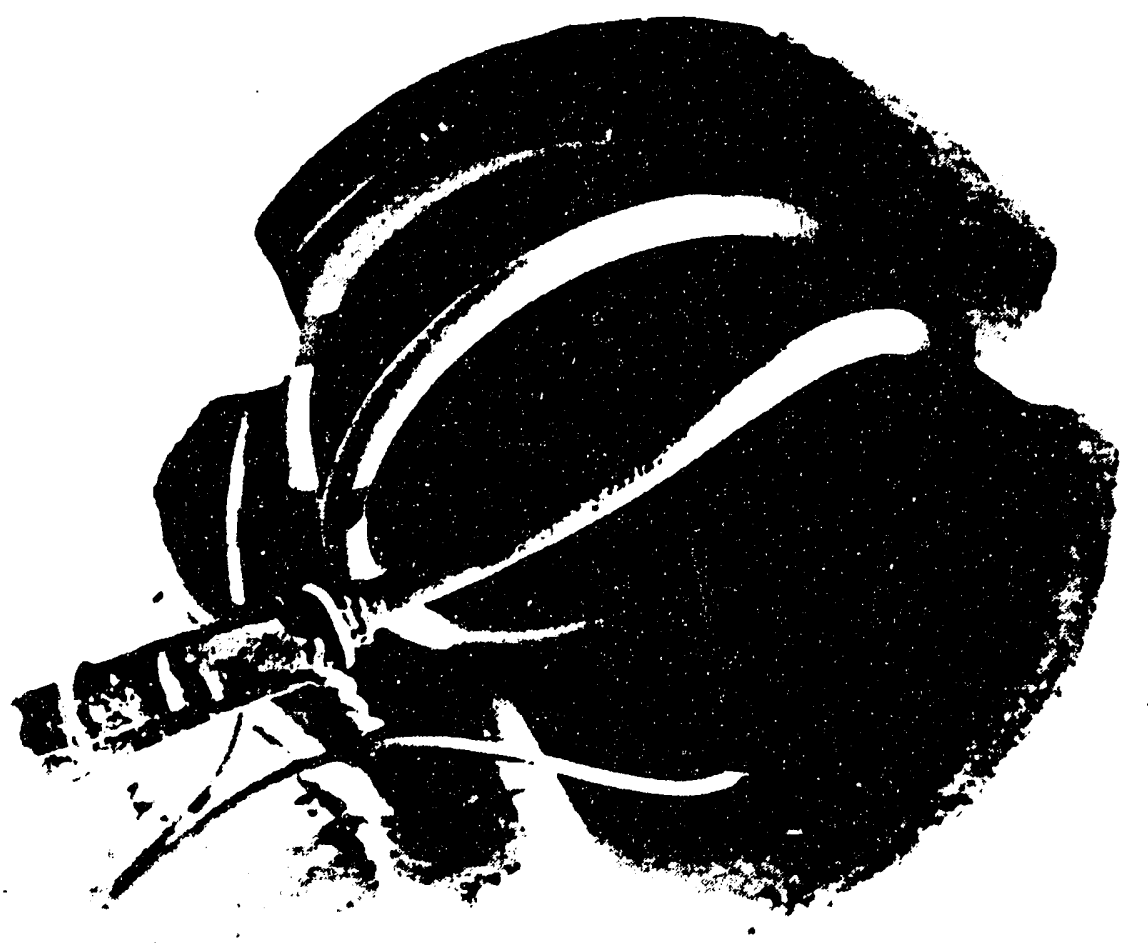

Fgure 48. Heater Coll With Dusting of Partlculate. 
The mount and plug were modified for HESR-20, which was run without materiais installed. Again, the rig ran very smoothly at an equivalence ratio of 1.20 , buming $90.5 \mathrm{lbs}$ of CWM in 4 hours. To correct the dust leakage problems, a cup was fabricated from RA-330 to secure the candle and Interam gasketing material, which was suggested by Industrial Filter \& Pump, in this new mount. The cup assembly was mounted flush with the tubesheet. Rather than weld the cup to the tubesheet, l.e., to prevent dust leakage, a refractory material was used to seal the gap. This method was judged superior as grinding off a weld would almost certainly lead to a broken candle. The filter vessel plug was wrapped in a blanket material which was held in place with nichrome wire. When the plug was placed inside the vessel, the insulating blanket created a seal around the plug stopping ash leakage. Upon removal of the candle from the fitter vessel, no ash leakby was observed. However, after further inspection, the Interam gasket in the candle mount was excessively deteriorated such that th could not be run again, and another seal material would be necessary.

HESF-21 assessed another modified candle mount. In place of the Interam gasket, a ceramic blanket material was used in the same mount assembly which is illustrated in Figure 49 . This material also has cushioning properties that permits the candle to have some flexibility. The run started in the usual manner with a six hour preheat period on diesel fuel, followed by four hours on CWM, buming a total of $96 \mathrm{lbs}$ of coal slumy fuel. The nun concluded with a three hour period of diesel to facilitate slag flow into the pit. It was suspected that in previous runs the more rapid shutdown procedure was responsible for slag freezing around the impactor. Upon teardown of the rig, this modified procedure appeared to have lessened the problem; however, frozen slag deposits were still observed around the impactor. Having inspected the candle mount, it was discovered that the high temperature ceramic wool material used as a gasketing material had failed due to improper installation. The exposed material was located downstream of the filter vessel. It apparently blew out during the run.

The use of the ceramic wool gasketing material in the candie mount was tested again in HESR22. The combustor ran well at an equivalence ratio of 1.15 (typ). A four hour run was performed burning 82 bs of CWM. No difficulties were encountered during the run. Upon inspection of the rig, no ash was found in the material sample section, nor around the candle mount or filter vessel plug. The new mounting system was successful.

At this point in testing, three methods of mounting a candle to a tubesheet have been analyzed. The first method was the so-called rigid-mourt method where the candle is cemented into a cup with a refractory material. This formed a gas tight seal, but did not permit candle movement. Candles have failed with this type of mount, however, it is not clear whether the mount was part of the cause. The Industrial Filter \& Pump method used an Interam gasketing material to provide the seal. Several tests in the Hot End Simulation Rig revealed that this material had a propensity to partially disintegrate at high temperatures. In earlier tests, portions of the material had disappeared. The third method tested used a ceramic wool material in the mount. This mount method was similar to the IF\&P design with the gasketing material being the primary difference.

The ceramic wool is capable of withstanding the high temperature environment and it provides some cushioning or shock-absorption of the candle which extends the candle llfe. This mount is the favored method at the present time. 


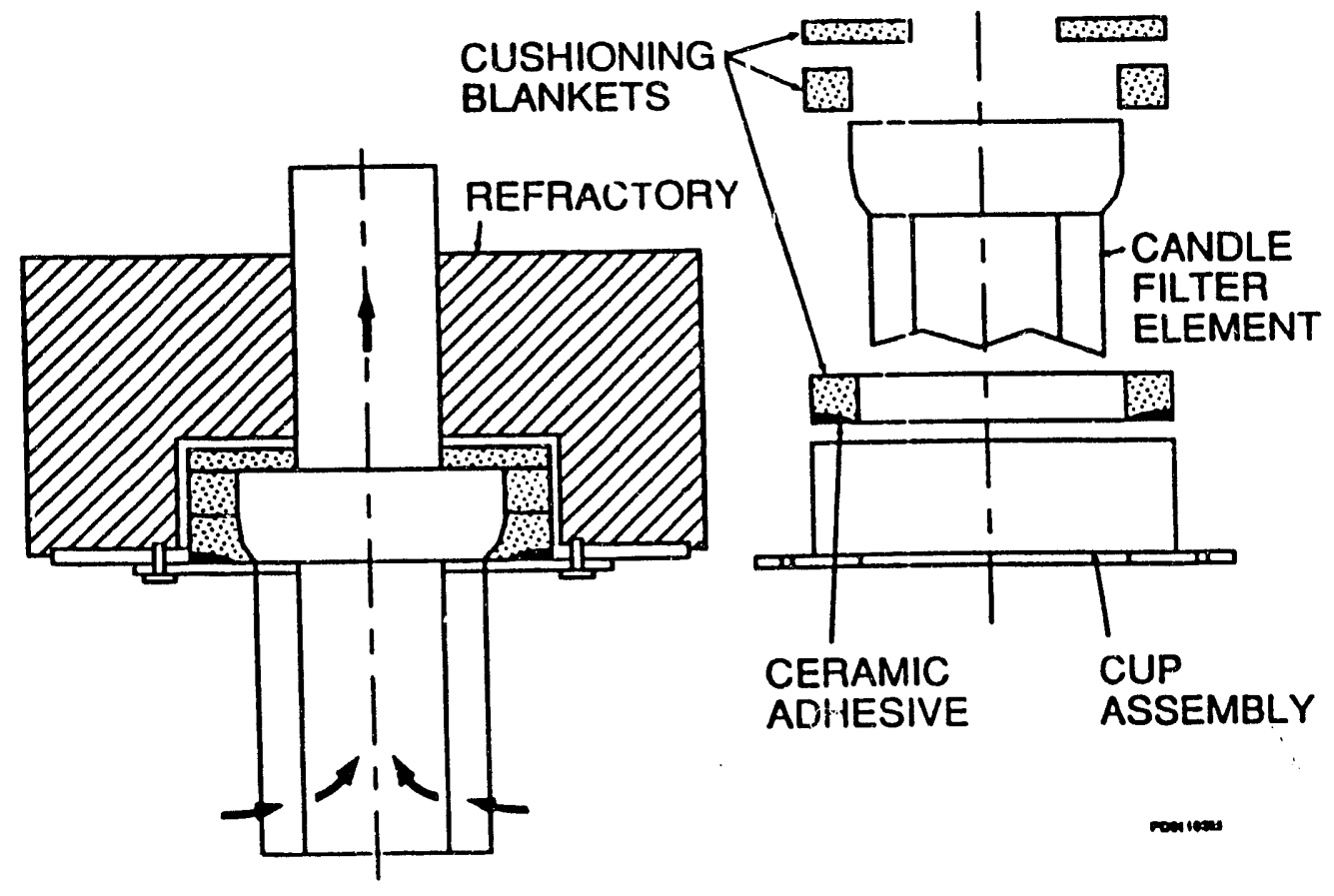

Figure 49. Candle Filter Mount

A 100 hour material test was attempted as HESR-23. Combustor operation was not stable. Large fluctuations were observed in the air assist and primary air pressures, leading to erratic flows and difficulty in controlling test parameters. In checking the system for the source of the air problem, the air assist was lost which led to the subsequent plugging of the injector, only 5 hours into the nun. After several unsuccessful attempts to clear the injector, a shutdown procedure was initiated. Post-test inspection of the rig revealed a factly air assist turbine flowmeter. After several attempts to clean it, no progress was achieved. The flowmeter was sent back to the manufacturer for recalibration. The heaters and material samples were installed for this test. Although sample section inlet temperatures reached only $949^{\circ} \mathrm{F}$, with material highs of $675^{\circ} \mathrm{F}$, the heaters worked well with no complications encountered.

The test objective of HESR-24 was to expose the materials to the combustion exhaust for 100 hours, however, a number of problems occurred throughout the run resulting in a premature termination. These problems included an air leak out of the material sample section, which resulted directly in the run termination, a heater fallure, erratic candle operation, frozen slag accumulations around the impactor, and plugging of the injector.

In the initial stages of the run, the $\Delta P$ across the candle gradually increased to a high of 5 psid. Pulse cleaning was effective initially, however, sticky ash was severe enough that pulse cleaning eventually had ittle effect. It was at this point in the run that the injector plugged, combustor pressure was lowered, and the fuel was switched back to DF\#2. Upon resumption of CWM, the candle appeared to be operating normally with a differential pressure ranging between 1 and 2 psid. It was assumed that the relatively rapid changes that occurred when the injector plugged 
unseated the candle enough to allow a leak of gas and ash. An unseated candle was observed in post-iest inspection.

Another problem encountered was with the impactor area. As soon as the rig was changed over to CWM, the impactor temperatures began to fall. After approximately 12.5 hours into the run the temperature at the impactor read $1730^{\circ} \mathrm{F}$, much lower than expected at that time. Such emperatures are indicative of frozen slag accumulations.

The heaters/sample section was another problem area. Roughly 12 hours into the run, it appeared that the heaters were not working properly. The materials seemed to reach a steady state temperature. Although the heater setpoint was continually increased, the heaters did not respond accondingly. In the material sample section spool, a sizeable leak was detected in the instrumentation section where the thermocouples are brought out from the casing. This leak was great enough, along with the impactor and candle difficulties, to abort the run and initiate a normal shutdown procedure.

Post HESR-24 inspection revealed a slagged over impactor, a slagged primary zone, a glass-like material on the candle, and a heater coll fallure. Not much ash was observed in the transition zone going to the filter vessel as has been previously seen. The secondary zone also looked much better as there was little accumulation of ash or slag around the air injection ports.

Upon removal from the filter vessel, a glass-like material was observed on the candle. Once the sticky ast cools, a hard, brittle substance is formes, and has been seen in previous tests. This matter can be easily removed. Since the candle experienced no physical degradation, it will be reused.

A continuity check of the heaters revealed that the aft one was burnt out. The heaters have been removed from the spool and a new method of heating the material samples is being investigated. Examination of the heater coils did not expose the nature of the fallure. The physical appearance of both coils was the same as upon installation, except for a fine layer of particulate observed on the heaters.

To resolve the slagged over impactor problem, a new primary zone, impactor section, and slag pit were designed and recast. The casings remained the same with only the internal refractory shape being redesigned. The primary zone and the impactor section features a continuous conical shape, shown in Figure 50, with the top of the cone remaining at 4 inches and the bottom of the cone opening up to 8 inches at the base of the impactor spool. This new design does not incorporate an impactor nor does it require the slag to flow down into a slag pit as had been previously attempted. The bottom section of the cone which sits in the impactor spool was designed as a removable crucible. With this concept, the slag can accumulate in the crucible partially filling the increased volume. Although the residence time will shorten over the course of the run due to the accumulation of slag, this will not significantly affect combustor performance because of the increased impactor spool volume and inherently low flow rate. To decrease downtime, the slag filled crucible can be easily removed after a run, and a new one installed. 


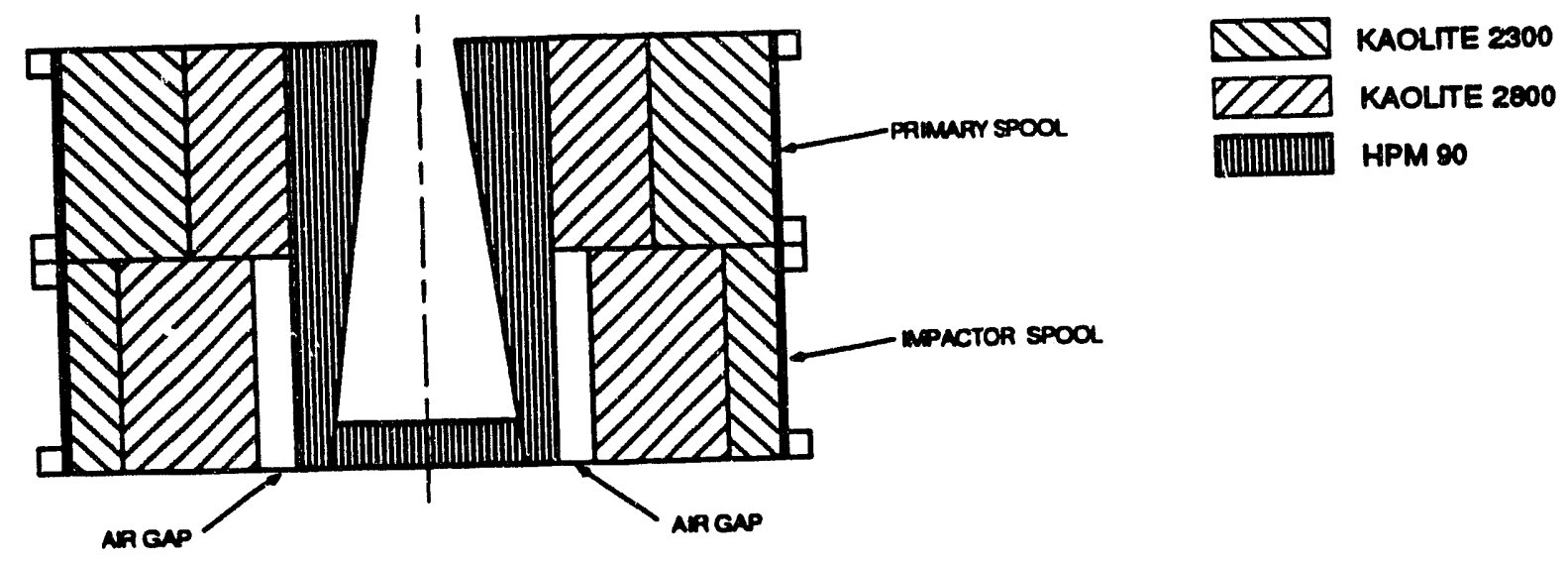

Figure 50. Conical Primary Zone and Impactor Section

The slag pit itself was filled with a silica sand and a refractory board was placed in between the slag pit and impactor spools to fill the void when the spools are tightened down. The slag pit is essentially closed off with the crucible in the impactor spool acting as the new pit. In the event that the original pit was required, the sand can be easily removed.

Due to the inexplicable heater fallures, a new strategy of supplementing material sample section heat was developed. The new concept employs the use of a natural gas and air mixture which impinge on a baffle upstream of the material samples. This method relys on the intemal combustion of the air and natural gas through a modified torch nozzle. The nozzle tip is shielded by another tube to protect the flame from being extinguished by the passing CWM combustion exhaust. It is expected that as the $\mathrm{ig}$ heats up, the natural gas will be leaned out to a point where it will not be required.

HESR-25 was performed to test the continuous conical primary zone and impactor section. The rig operated very smoothly during the 4 hour check run. No materials were installed for this test. Boroscoping after the run confirmed that the new primary zone and impact section was successful.

The main objective of the next test series was to evaluate the modification made to the supplemental heating spool prior to the material sample section. This modification consists of torch ignitor which supplies air and natural gas to the spool plece just ahead of the materials. HESR-26 demonstrated that the natural gas would not internally combust as expected. HESR-27 addressed this problem. A small diesel supply was added, in conjunction with the natural gas supply, to act as a pilot. The diesel is used to mix with the alr and ignite in the hot, coal combustion exhaust. Once the diesel supply is expended, the natural gas would easily ignite in the stable diesel bum. HESR-27 revealed that a larger diesel supply was required for stable combustion. The supply was modified and HESR-28 was performed. In this test it was found that a larger natural gas orfice was required to effectively supply the torch ignitor. The natural gas orifice will be modified and a evaluation test will be performed prior to the beginning of the 100250 hour run. 
In summary, long-term ig reliability has been improved. A conical primary zone and Impactor section have been developed and tested to allow for slag accumulation during 250-hour tests. A candle filter shroud protects the element from direct impingement of particulate, which previously led to blinding of the candle. A flexible candle mount system has been established and has been successful during extended testing. Supplemental heating of the material sample section is currently being modified and is the objective of the next HESR test. Once the sample section torch heating is demonstrated effectively, the 1000 hour test series will begin. 


\section{PHASE III - TASK 1 - DESIGN}

\subsection{SPECIFIC ITEMS OF PROGRESS}

- Design of the engine parts required to integrate the combustor island started.

\section{DISCUSSION}

Some preliminary work was done in Phase III to determine the best way of obtaining the necessary parts to provide the ducting required to integrate the combustor island with the generator. The design of a steam cooled turbine inlet duct has begun. It was planned to use the outer housings from an eartier version of the Centaur and modity them to fit the Type H Centaur. One of the housings may have to be fabricated. The interface between these parts and the ducting is being studied. The turbine inlet scroll will be steam cooled in order to accommodate the required turbine inlet temperature of approximately $1920^{\circ} \mathrm{F}$ and to trim the radlal inlet temperature profile. Planning and selection of equipment for the engine test site is also in progress. 


\section{APPENDIX A}


Appendix A contains CWM slumy fuels which have been tested at Solar's combustor rigs (TSSC, IBSTF, and HESR) and full-scale combustor. The slurry fuel properties, coal source, particle size, and ash composition and fusion temperature are listed for each tested fuel. The majority of slumies were formulated with the blend of eastern Kentucky coals, except few coals have been used for special testing purposes. Different batch name was referred to each preparation and shipment. 


\begin{tabular}{|c|c|c|c|c|c|c|}
\hline Cod & c & D & $\mathbf{E}$ & $F$ & $\mathbf{a}$ & H \\
\hline Sowner & 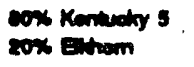 & $\begin{array}{l}\text { cox Kontuchy } 5 \\
20 \% \text { Evtom }\end{array}$ & Epint & Pustavion & 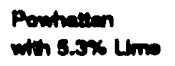 & $\begin{array}{l}\text { 75\% Chen Elthom } \\
25 \% \text { Rod Elhom }\end{array}$ \\
\hline 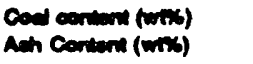 & $\begin{array}{r}84.10 \\
2.10\end{array}$ & $\begin{array}{l}50.50 \\
1.20\end{array}$ & $\begin{array}{l}55.50 \\
1.70\end{array}$ & $\begin{array}{l}60.60 \\
3.40\end{array}$ & $\begin{array}{r}40.60 \\
7.50\end{array}$ & $\begin{array}{l}8400 \\
1.25\end{array}$ \\
\hline 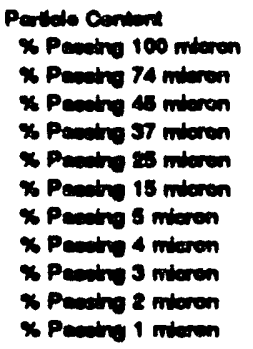 & 100.10 & Ca.10 & $\begin{array}{l}0.60 \\
60.70 \\
60.00 \\
71.60 \\
6.70 \\
5.40 \\
24.00\end{array}$ & $\begin{array}{l}100.00 \\
100.00 \\
05.10 \\
21.70 \\
04.50 \\
74.00 \\
34.00\end{array}$ & $\begin{array}{r}100.00 \\
100.00 \\
10.50 \\
20.70 \\
60.50 \\
74.00 \\
30.00\end{array}$ & 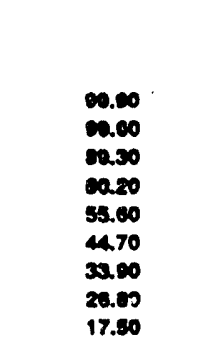 \\
\hline 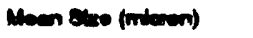 & 14.10 & 21.00 & 21.00 & 11.80 & 11.50 & $\mathbf{2 . 1 0}$ \\
\hline 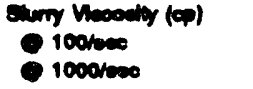 & 300.00 & $\begin{array}{l}300.00 \\
275.00\end{array}$ & $\begin{array}{l}350.00 \\
400.00\end{array}$ & $\begin{array}{l}360.00 \\
700.00\end{array}$ & $\begin{array}{l}300.00 \\
250.00\end{array}$ & $\begin{array}{l}223.00 \\
425.00\end{array}$ \\
\hline Emy (tom) & $7 \infty \infty 0$ & 7001 & 7010 & $\pi \times$ & 6100 & 7245 \\
\hline \multicolumn{7}{|l|}{ Prodimno Andyde (wtx) } \\
\hline Ach & 3.80 & 2.23 & $3 . \infty$ & $\mathbf{3 . 5 2}$ & 13.12 & 2.30 \\
\hline $\begin{array}{l}\text { Volelloe } \\
\text { Fred Cotoen }\end{array}$ & $\begin{array}{l}36.10 \\
60.02\end{array}$ & $\begin{array}{l}34.00 \\
62.07\end{array}$ & $\begin{array}{l}37.40 \\
50.57\end{array}$ & $\begin{array}{l}37.51 \\
56.07\end{array}$ & $\begin{array}{l}30.43 \\
47.74\end{array}$ & $\begin{array}{l}31.70 \\
66.00\end{array}$ \\
\hline \multicolumn{7}{|l|}{ Untrimes Andyals } \\
\hline Gmon & 77.10 & 04.18 & 81.20 & 81.44 & 00.30 & 03.02 \\
\hline Oxym & 1438 & 200 & $\mathbf{2 4 5}$ & $\mathbf{8 . 6 0}$ & 6.10 & 7.35 \\
\hline Mrtrogen & 5.60 & 5.20 & 401 & 5.25 & 5.67 & 5.00 \\
\hline Niroen & 1.22 & 1.04 & 1.51 & 1.50 & 1.53 & 1.15 \\
\hline and & 0.00 & 0.80 & 0.60 & 3.13 & 3.20 & 0.50 \\
\hline \multicolumn{7}{|l|}{ An Compocilion } \\
\hline $\mathrm{sO}_{2}$ & 50.00 & 40.20 & 4.00 & 4200 & 13.60 & 32.50 \\
\hline$A 0_{1}$ & 22.10 & 3200 & 24.70 & 220 & 7.60 & 21.20 \\
\hline $\mathrm{F}=\mathbf{0}$ & 11.60 & 1820 & 1200 & $\$ 0.60$ & 7.10 & 10.00 \\
\hline CeO & 1.35 & 5.02 & 8.10 & 1.01 & 18.20 & 400 \\
\hline mo & 0.01 & 1.10 & 1.30 & 0.42 & 11.40 & 0.03 \\
\hline $\mathrm{ML}_{4} \mathrm{O}$ & 0.01 & 1.70 & 0.50 & aso & 1.21 & 200 \\
\hline K.o & $1 . \infty$ & 0.50 & 0.31 & 1.30 & 0.40 & 1.30 \\
\hline ina & 207 & 1.07 & 1,60 & 1.11 & 0.30 & 1.00 \\
\hline $\min$, & 0.07 & 0.07 & 0.02 & 0.66 & 0.04 & \\
\hline$P_{2} O_{0}$ & 0.31 & 0.40 & 0.07 & $0 . \infty$ & 0.04 & 0.20 \\
\hline $\mathrm{V}_{2} \mathrm{O}_{0}$ & 2.00 & 0.07 & 0.06 & 0.08 & 0.02 & \\
\hline Po & 0.04 & 0.08 & 0.00 & 0.06 & 0.01 & \\
\hline \multicolumn{7}{|c|}{ Ach Fuden Temporeturs (A) } \\
\hline 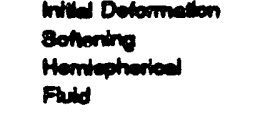 & $\begin{array}{r}23702490 \\
+27002960 \\
+270002050 \\
+27002700\end{array}$ & 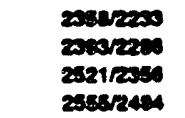 & 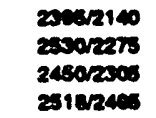 & 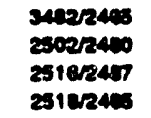 & 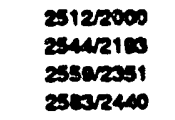 & 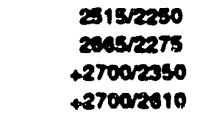 \\
\hline
\end{tabular}




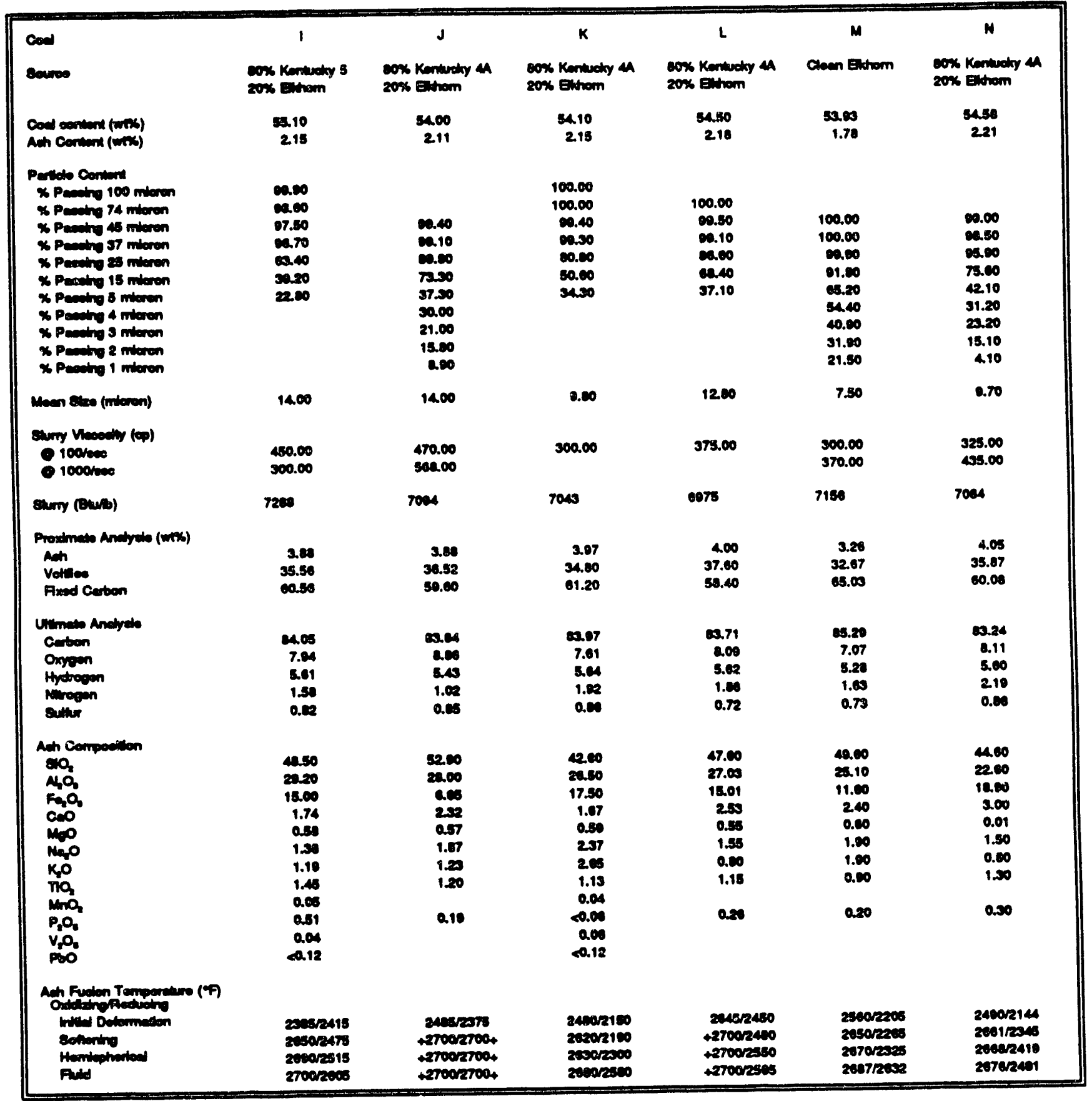




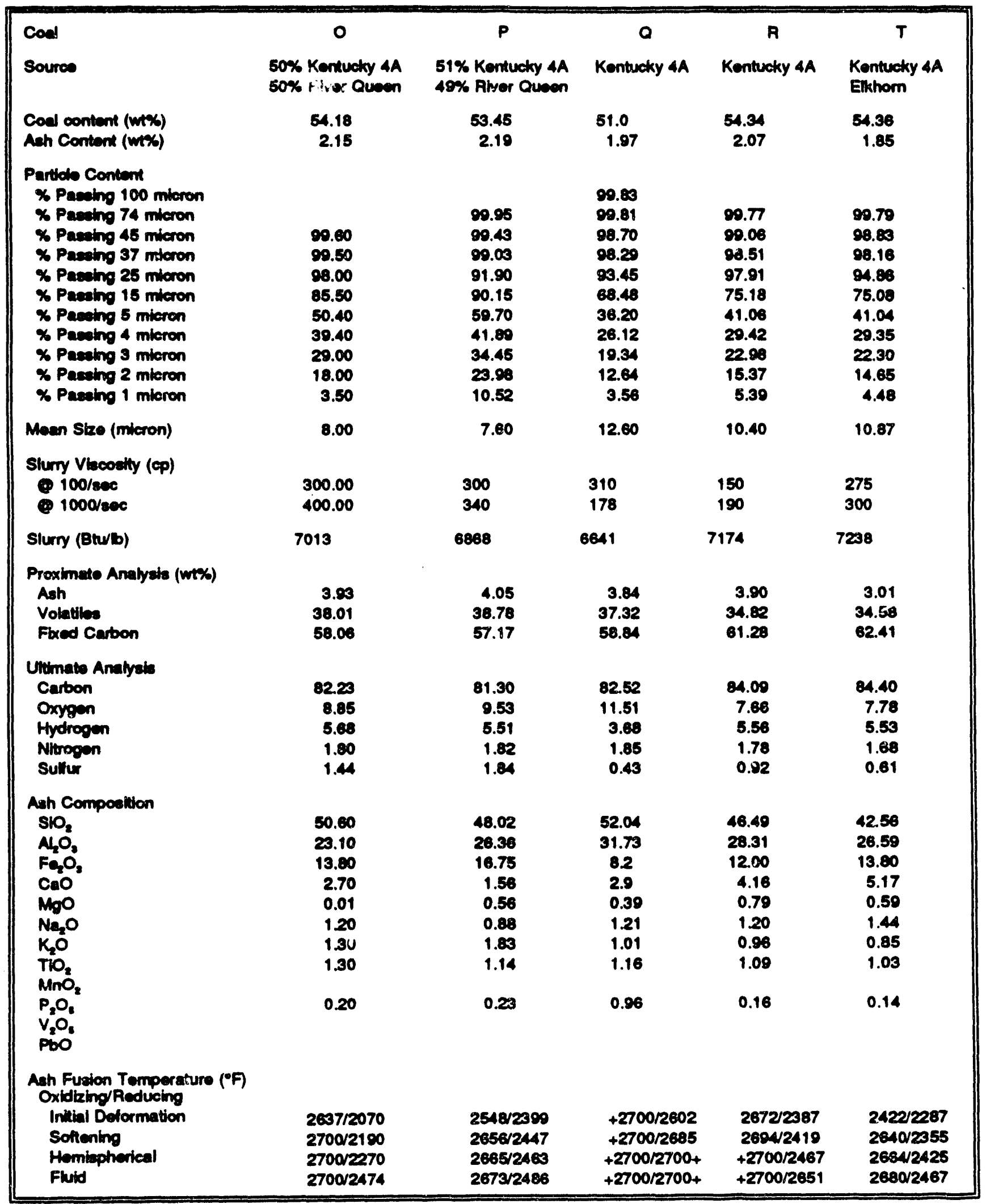




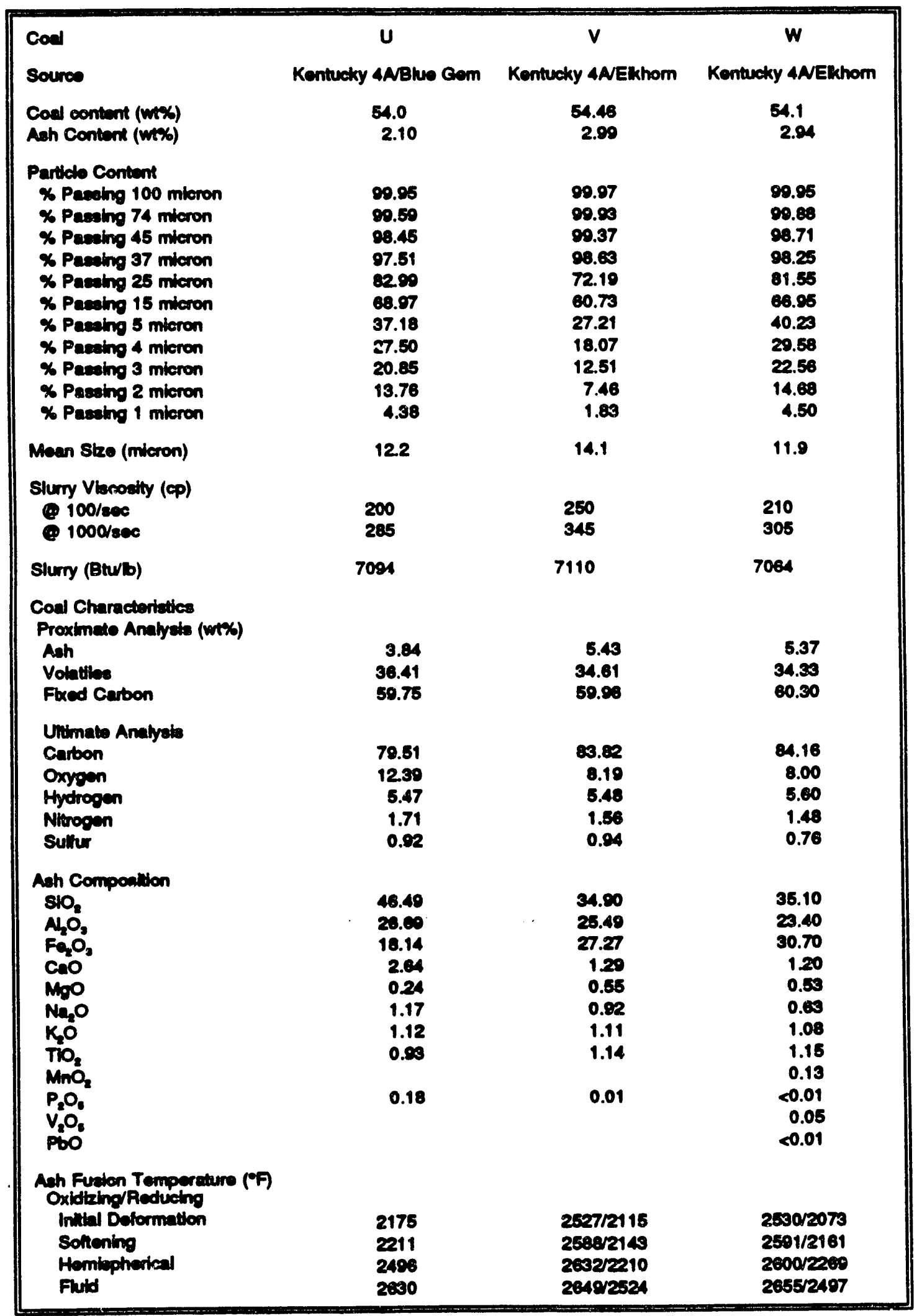



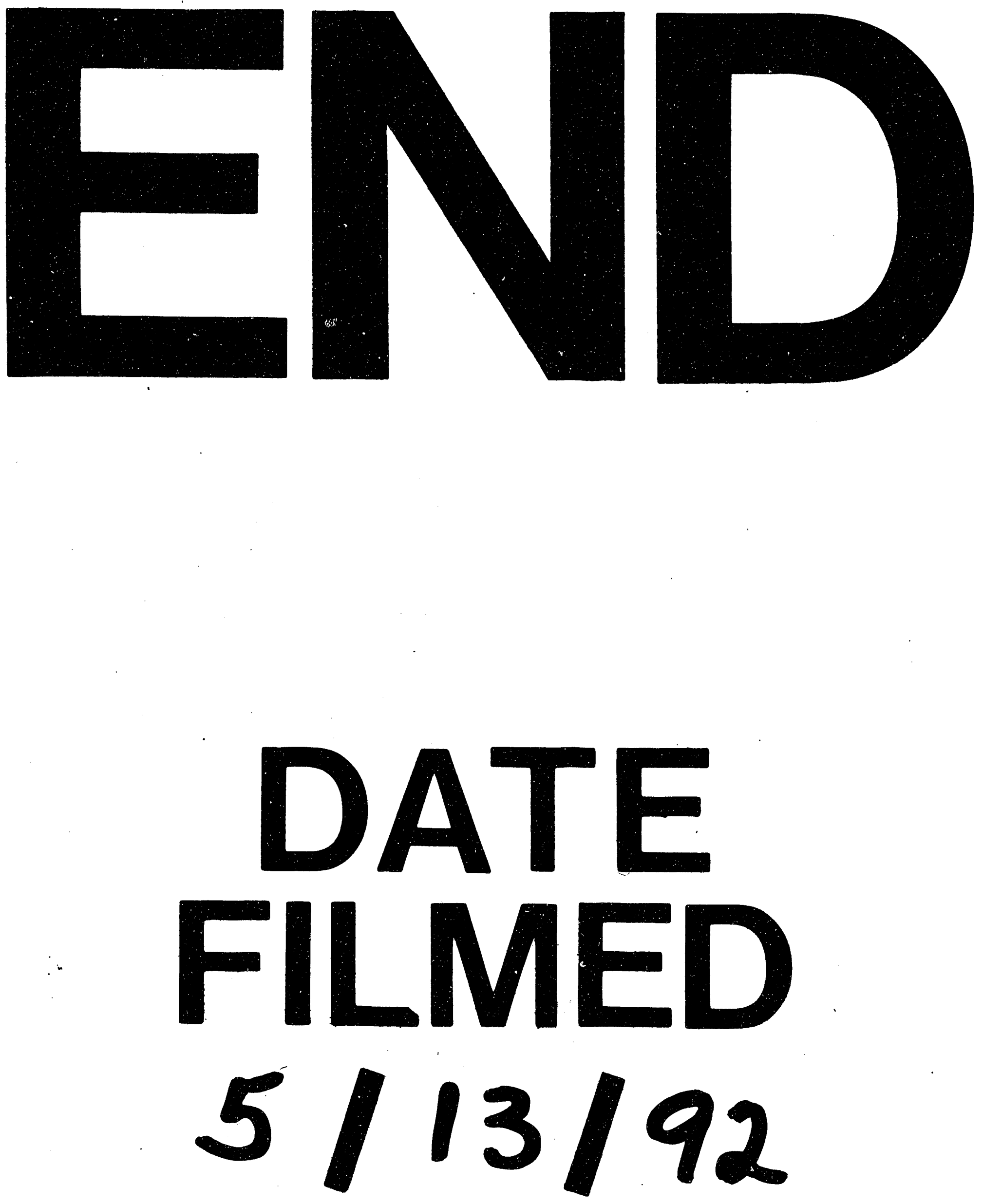
